PAULA BRUZADELLE VIEIRA

CULTURA DE CÉLULAS DE DROSOPHILA MELANOGASTER (S2) EM PROCESSO CONTÍNUO

Dissertação Apresentada à Escola Politécnica da Universidade de São Paulo para a obtenção do título de Mestre em Engenharia

São Paulo

2010 
PAULA BRUZADELLE VIEIRA

\section{CULTURA DE CÉLULAS DE DROSOPHILA MELANOGASTER (S2) EM PROCESSO CONTÍNUO}

Dissertação Apresentada à Escola Politécnica da
Universidade de São Paulo para a obtenção do título de Mestre em Engenharia

Área de concentração: Engenharia Química

Orientador: Prof. Dr. Aldo Tonso

São Paulo

2010 
Este exemplar foi revisado e alterado em relação à versão original, sob responsabilidade única do autor e com a anuência de seu orientador.

São Paulo, de agosto de 2010.

Assinatura do autor

Assinatura do orientador

FICHA CATALOGRÁFICA

Vieira, Paula Bruzadelle

Cultura de células de Drosophila melanogaster (S2) em processo contínuo / P.B. Vieira. -- ed.rev. -- São Paulo, 2010.

$135 \mathrm{p}$.

Dissertação (Mestrado) - Escola Politécnica da Universidade de São Paulo. Departamento de Engenharia Química.

1. Drosophila 2. Metabolismo celular 3. Vírus da raiva 4. Produção contínua 5. Células de inseto 6. Quimiostato I. Universidade de São Paulo. Escola Politécnica. Departamento de Engenharia Química Il.t. 


\section{DEDICATÓRIA}

Aos meus pais, pela oportunidade de vida que eles me ofereceram.

Ao meu marido, Eugênio, pelo amor, carinho, incentivo e companheirismo. 


\section{AGRADECIMENTOS}

Ao Prof. Dr. Aldo Tonso, pela amizade e pela orientação no desenvolvimento deste trabalho. Terei sempre comigo o reconhecimento pelo importante papel que tiveste neste início de vida acadêmica.

Ao Dr. Carlos Augusto Pereira, o qual abriu espaço para que eu fizesse parte do grupo temático óExpressão de genes heterólogos em células de dípteros: biologia molecular e engenharia de processosô

À Dr. ${ }^{a}$ Elizabeth Augusto, Prof. ${ }^{a}$ Dr. Ângela Maria Moraes, Prof. ${ }^{a}$ Soraia Attie Calil Jorge e Dr. Renato Astray pelos momentos de valiosas discussões.

Ao Dr. Álvaro Paiva, pela amizade e paciência em ensinar-me na prática todos os cuidados dos cultivos de células animais.

Aos professores do B20: Prof. Dra. Maria Cândida Reginato Facciotti, Prof. Dra. Beatriz Van Kilikian, Prof. Dr. Pedro de Alcântara Pessoa Filho e Prof. Dr. Andreas Karoly Gombert pelos ensinamentos e atenção a qualquer hora.

À minha amiga Mariana, por todo conhecimento transmitido ao longo do mestrado que contribuiu muito para essa conquista.

Aos amigos especiais Zé Paulo e Thiago, pela ajuda constante até mesmo de tão longe, além das boas risadas e dos momentos de descontração.

Às amigas: Bianca, Kelly, Kátia, Cintia, Dani e Marilena pelas risadas, conselhos e momentos de reflexão.

Aos amigos relacionados com o projeto: Marcos, Alexandra, Ronaldo, Luciana, Cláudio, Kamilla, Juliana, Fabiana pelas discussões nos workshops e boa convivência.

Ao Marcelo Aguiar, em especial, pela ajuda e boa vontade com as amostras de amônia.

À Fátima pela ajuda em conseguir artigos que muitas vezes não estavam disponíveis no banco de dados da USP.

Aos funcionários Andrea, Orlinda e Walter pelo apoio e agradável convivência.

Ao CNPq e Fapesp pelo suporte financeiro. 
À Renata Spinassé com a sua amizade e carinho que mesmo à distância está sempre presente na minha vida.

Ao grande amigo André Aquino, por sua verdadeira amizade.

Aos amigos: Cris, Alex, Soraia, Rosário, Isabel, Affonso, Akemi, Louise pelos conselhos e momentos de alegria e descontração.

Aos meus cunhados: Eduardo, Ingrid e Karol pela amizade e pela torcida na realização deste objetivo.

À Sandra, minha sogra, por todo seu amor e carinho.

Aos meus avós, Dirlene e Rubens, por todo amor, incentivo, educação e carinho, sem a qual eu nada seria.

Aos meus pais, Claudino e Eliane, pelo verdadeiro Amor e pela educação transmitida, no qual foi fundamental para esta conquista.

Aos meus irmãos queridos Raul e Artur, pelo amor e por me trazerem tantas alegrias.

A meu marido Eugênio pelo amor, carinho e incentivo constante para a realização deste objetivo. Mais do que tudo, obrigada por fazer parte da minha vida.

Ao Dr. Celso Charuri, meu Mestre de Filosofia. Agradeço em cada segundo da minha vida pelo Amor, Compreensão, Respeito e Conhecimento transmitidos.

A todos que direta ou indiretamente colaboraram com a realização deste trabalho. 
óPara construir um mundo melhor basta seguir o que você reconhece como certo, cumprindo com coragem e acionando a verdade que é a razão da sua vida. Basta seguir o que você já sabe ser certo, e não ficar procurando o que é certo para seguirô 


\section{RESUMO}

As células de Drosophila melanogaster (S2) têm sido utilizadas como sistemas de expressão de proteínas recombinantes. Neste trabalho foi utilizada uma linhagem S2 geneticamente modificada com vetores de expressão para a produção da glicoproteína do vírus da raiva (GPV). O principal objetivo deste trabalho foi avaliar o comportamento destas células cultivadas em processo contínuo, visando-se manter elevadas concentrações celulares. Para os ensaios contínuos, utilizou-se meio livre de soro fetal bovino SF 900 II em um reator Biostat $\mathrm{B}$, com $500 \mathrm{~mL}$ de volume útil e controle de temperatura $\left(28^{\circ} \mathrm{C}\right)$, oxigênio dissolvido ( $30 \%$ da saturação com ar), frequência de agitação $(90 \mathrm{rpm})$ e monitoramento do $\mathrm{pH}$. Verificou-se o comportamento do metabolismo celular em diferentes vazões específicas de alimentação $\left(0,8 \mathrm{dia}^{-1}, 0,5 \mathrm{dia}^{-1}\right.$ e $\left.0,2 \mathrm{dia}^{-1}\right)$ através parâmetros como fatores de conversão e variáveis como concentração celular máxima, concentração residual de glicose e glutamina, dentre outras. Ainda, avaliou-se a influência de aminoácidos, tais como, glutamina, asparagina, prolina, serina e cisteína suplementados no meio de alimentação, sob a concentração celular alcançada no estado estacionário. Diferentes vazões específicas de alimentação - em estado estacionário - resultaram em concentrações celulares próximas entre si. A adição de glutamina $(1,7 \mathrm{~g} / \mathrm{L})$ no meio de alimentação não contribuiu para o aumento na concentração celular, indicando que este aminoácido não limitou o processo de crescimento celular. Uma observação similar ocorreu quando o meio SF 900 II foi suplementado com asparagina, prolina, serina e cisteína. Porém, a adição de cisteína $(0,3 \mathrm{~g} / \mathrm{L})$ isoladamente no meio de alimentação resultou em um aumento de $12 \%$ na concentração celular quando comparada ao meio SF 900 II puro. Assim, pode-se concluir que a cisteína limitava o crescimento celular. Verificou-se ainda que a célula não apresentou grande variabilidade nos diferentes ensaios, sob mesma vazão específica de alimentação. Isso indica que processo contínuo constituiria um método viável para a compreensão do metabolismo desta célula.

Palavras-chave: Drosophila melanogaster S2. Células de inseto. Metabolismo. Glicoproteína do vírus da raiva. Processo Contínuo. Quimiostato. 


\begin{abstract}
Drosophila melanogasterës cells (S2) have been used as expression systems for recombinant proteins. This study uses a genetically modified S2 line with expression vectors for production of rabies virus glycoprotein (RVPG). The main objective was to evaluate the growth trend of S2 cells in a continuous process, aiming to maintain high cell concentrations. In order to set the continuous culture, the experiments used serum-free medium SF 900 II in a Biostat B reactor, with working volume of $500 \mathrm{~mL}$ and temperature controlled at $28 \circ \mathrm{C}$, dissolved oxygen at $30 \%$ air saturation, agitation speed at $90 \mathrm{rpm}$, and $\mathrm{pH}$ monitoring. Cellular metabolism behavior was observed under different dilution rates $\left(0.8\right.$ day $^{-1}, 0.5$ day $^{-1}$, and 0.2 day $\left.^{-1}\right)$ through parameters such as yield factors, in addition to variables such as maximum cell concentration, residual concentration of glucose and glutamine, among others. Yet, this work evaluates the influence of amino acids such as glutamine, asparagine, proline, serine and cysteine supplemented in the feed, over cellular concentration value reached in the steady state. Different dilution rates decreasing (under steady state) resulted in cell concentrations quite simillar. The addition of glutamine $(1.7 \mathrm{~g} / \mathrm{L})$ in the feed did not contribute to the increase of cell concentration, which indicates that this amino acid did not limit cell growth process. A similar observation occurred when SF 900 II medium was supplemented with asparagine, proline, serine and cysteine. However, the cysteine addition $(0.3 \mathrm{~g} / \mathrm{L})$ alone in the feed resulted in a $12 \%$ increase in cell concentration, compared to pure SF 900 II. Thus, it is possible to conclude that cysteine limited cell growth. It was also found that the cell did not show great variability in the various tests under the same dilution rate. This indicates that chemostat culture would be a viable method for understanding the metabolism of this cell.
\end{abstract}

Key words: Drosophila melanogaster S2. Insect cells. Metabolism. Rabies vírus glycoprotein. Continuous culture. Chemostat culture. 


\section{Lista de Tabelas}

Tabela 1: Descrição dos ensaios com células S2AcGPV realizados por Swiech et al., $2008 \mathrm{~b}$

Tabela 2: Vantagens e desvantagens do processo contínuo com relação ao descontínuo.

Tabela 3: Concentração de parte dos componentes do meio SF 900 II utilizado neste trabalho. 40

Tabela 4: Condições de cultivo dos ensaios em Batelada. 48

Tabela 5: Condições de cultivo dos ensaios contínuos 49

Tabela 6: Comparação entre a Batelada 1 e a Batelada 2 71

Tabela 7: Variáveis calculadas para diferentes vazões específicas de alimentação no estado estacionário para o cultivo Contínuo 1. 82

Tabela 8: Variáveis calculadas em estado estacionário nas diferentes concentrações de glutamina no meio de alimentação ao longo do Contínuo 3.

Tabela 9: Variáveis calculadas em estado estacionário nas diferentes concentrações de aminoácidos no meio de alimentação ao longo do Contínuo 5

Tabela 10: Consumo e produção de cada aminoácido nos estados estacionários do Contínuo 3.

Tabela 11: Variáveis calculadas na fase descontínua dos ensaios Contínuos. 121

Tabela 12: Cálculo de fatores de conversão nos estados estacionários com $\mathrm{D}=0,5 \mathrm{dia}^{-1}$ nos Contínuos 1,3 e 5 . 


\section{Lista de Gráficos}

Gráfico 1: OD, pH e a Concentração de células viáveis da Batelada 1 ao longo do tempo.

Gráfico 2: Crescimento Celular das Células S2MtGPV. 60

Gráfico 3: (a) Determinação de $\varepsilon_{x, \text { máx }}$ da Batelada 1 e (b) Curva de $\mu_{x}$ ao longo do cultivo.

Gráfico 4: Concentração de Glicose e Lactato ao longo do tempo na Batelada 1 . ...61

Gráfico 5: Concentração de glutamina e glutamato residual na Batelada 1. 62

Gráfico 6: Concentração e Teor Específico de GPV ao longo do Tempo. 64

Gráfico 7: OD, Frequência de Agitação, Temperatura, pH e a Concentração de células viáveis da Batelada 2 ao longo do tempo

Gráfico 8: Crescimento Celular das Células S2AcGPV ao longo do tempo na Batelada 2.

Gráfico 9: (a) Determinação de $\varepsilon_{\text {máx }}$ e (b) Curva de $\varepsilon_{x}$ ao longo do tempo na Batelada 2. 66

Gráfico 10: Concentração de Glicose e de Lactato ao longo do tempo na Batelada 2.

Gráfico 11: Concentração de Glutamina e de Glutamato ao longo do tempo na Batelada 2 .68

Gráfico 12: Concentração e teor de GPV ao longo do tempo na Batelada 2. 69

Gráfico 13: Correlação entre absorbância e concentração celular total. .70

Gráfico 14: Correlação entre massa seca de células e concentração celular total. ..70 Gráfico 15: (a) Comparação da GPV específica e (b) a concentração de GPV entre a Batelada 1 e Batelada 2. .72

Gráfico 16: Comparação da produtividade entre a Batelada 1 e Batelada 2..............72 Gráfico 17: Velocidade específica de crescimento ao longo do tempo nos experimentos em schott.

Gráfico 18: Produção específica de crescimento ao longo do tempo nos experimentos em schott.

Gráfico 19: (a) Determinação de $\varepsilon_{\text {máx }}$ e (b) Curva de $\varepsilon_{x}$ ao longo do tempo no Contínuo 1

Gráfico 20: OD, pH e a Concentração de células viáveis do Contínuo 1 ao longo do tempo.

Gráfico 21: Concentração Celular e Viabilidade ao longo do Contínuo 1 79

Gráfico 22: Concentrações de Glicose e Lactato ao longo do tempo. .80

Gráfico 23: Concentração de glutamina e glutamato residual e de amônia ao longo do tempo no Contínuo 1. 
Gráfico 24: Concentração de aminoácidos nos diferentes estados estacionários alcançados no Contínuo 1 em comparação com a concentração inicial do meio SF $900 \mathrm{II}$.

Gráfico 25: Curvas de crescimento dos ensaios em schott com diferentes concentrações iniciais de glutamina. (a) Controle A $1,7 \mathrm{~g} / \mathrm{L}$, (b) B ï $2,55 \mathrm{~g} / \mathrm{L}$, (c) C ï $3,4 \mathrm{~g} / \mathrm{L}$ e (d) D ï 4,8 g/L

Gráfico 26: Concentração de glicose residual e formação de lactato ao longo do tempo dos ensaios em schott com diferentes concentrações inicias de glutamina. (a) Controle A 1,7 g/L, (b) B ï 2,55 g/L, (c) C ï 3,4 g/L e (d) D ï 4,8 g/L. () Glicose, (ǒ) Lactato.

Gráfico 27: Concentração de glutamina e glutamato residual ao longo do tempo dos ensaios em schott com diferentes concentrações inicias de glutamina. (a) Controle A $1,7 \mathrm{~g} / \mathrm{L}$, (b) B Ï 2,55 g/L, (c) C ï 3,4 g/L (d) D ï 4,8 g/L. (I ) Glutamina, (ǒ) Glutamato.

Gráfico 28: Concentração entre ensaios em schott com diferentes concentrações inicias de glutamina. (a) $X v_{\text {máx }}$, (b) $\mu_{x, \text { máx, }}$ (c) $Y_{X / G L N}{ }^{\text {EXP }}$, (d) $Y_{X / G L C}{ }^{\text {EXP }}$, (e) GPVe ${ }^{\text {EXP }}$ e (f) $\forall_{\text {GPV. }}$

Gráfico 29: (a) Determinação de $\varepsilon_{x, \text { máx }}$ e (b) Curva de $\varepsilon_{x}$ ao longo do tempo no Contínuo 3.

Gráfico 30: OD, pH e a Concentração de células viáveis do Contínuo 3 ao longo do tempo. 92

Gráfico 31: Concentração celular e viabilidade ao longo do Contínuo 3. .93

Gráfico 32: Concentração de glicose residual e de Lactato ao longo do tempo no Contínuo 3. .93

Gráfico 33: Concentrações residuais de glutamato e de glutamina ao longo do Contínuo 3. 94

Gráfico 34: Concentração e teor de GPV ao longo do Contínuo 3. 98

Gráfico 35: Concentração residual de aminoácidos no dois estados estacionários alcançados em comparação com o meio SF 900 II no Contínuo 3. .99

Gráfico 36: Concentração de aminoácidos nos estados estacionários do Contínuo 1 e 3 com $D=0,5$ dia- 1 e meio SF 900 II. 100

Gráfico 37: Curva de crescimento dos ensaios em schott com diferentes concentrações inicias de aminoácidos. (a) Controle SF 900 II puro, (b) 4 aa ï 2,1 g/L de Asparagina, 1,1 g/L de Prolina, 1,3 g/L de Serina, 0,26 g/L de Cisteína (c) Asn 2,1 g/L de Asparagina, (d) Pro ï 1,1 g/L de Prolina, (e) Ser - 1,3 g/L de Serina e (f) Cis - 0,26 g/L de Cisteína. 102

Gráfico 38: Concentração de glicose residual e de lactato dos ensaios em schott com diferentes concentrações inicias de aminoácidos. (a) Controle SF 900 II puro, (b) 4 aa ï 2,1 g/L de Asparagina, 1,1 g/L de Prolina, 1,3 g/L de Serina, 0,26 g/L de Cisteína (c) Asn - 2,1 g/L de Asparagina, (d) Pro ï 1,1 g/L de Prolina, (e) Ser 1,3 g/L de Serina e (f) Cis - 0,26 g/L de Cisteína. () Glicose, (ǒ) Lactato..............103 Gráfico 39: Concentração de glutamina e glutamato residual dos ensaios em schott com diferentes concentrações inicias de aminoácidos. (a) Controle SF 900 II puro, (b) 4 aa ï 2,1 g/L de Asparagina, 1,1 g/L de Prolina, 1,3 g/L de Serina, 0,26 g/L de 
Cisteína (c) Asn - 2,1 g/L de Asparagina, (d) Pro ï 1,1 g/L de Prolina, (e) Ser 1,3 g/L de Serina e (f) Cis - 0,26 g/L de Cisteína. () Glutamina, (ǒ) Glutamato.... 104 Gráfico 40: Comparação entre os ensaios em schott com diferentes concentrações de aminoácidos no meio SF 900 II. (a) Controle SF 900 II puro, (b) 4 aa ï 2,1 g/L de Asparagina, 1,1 g/L de Prolina, 1,3 g/L de Serina, 0,26 g/L de Cisteína (c) Asn 2,1 g/L de Asparagina, (d) Pro ï 1,1 g/L de Prolina, (e) Ser - 1,3 g/L de Serina e (f) Cis - 0,26 g/L de Cisteína. 105

Gráfico 41: (a) Determinação de $\varepsilon_{\text {máx }}$ e (b) Curva de $\varepsilon_{x}$ ao longo do tempo no Contínuo 3 109

Gráfico 42: OD, pH e a Concentração de células viáveis do Contínuo 5 ao longo do tempo. 111

Gráfico 43: Concentração celular e viabilidade ao longo do Contínuo 5. 112

Gráfico 44: Concentração residual de glicose e concentração de lactato ao longo do Contínuo 5 .

Gráfico 45: Concentração residual de glutamina e glutamato e produção de amônia ao longo do Contínuo 5.

Gráfico 46: Concentração e teor de GPV ao longo do Contínuo 5. 116

Gráfico 47: Concentração de aminoácidos no meio SF 900 II puro, no meio suplementado com Asn, Pro, Ser e Cis e no meio com Cis utilizado no Contínuo 5.

Gráfico 48: Concentração de aminoácidos nos meios de alimentação e nos diferentes estados estacionários alcançados no Contínuo 5. 119

Gráfico 49: Comparação entre os ensaios contínuos com $D=0,5$ dia $^{-1}$ em meio SF 900 II puro.

Gráfico 50: Concentração residual de aminoácidos nos estados estacionário alcançados com $\mathrm{D}=0,5 \mathrm{dia}^{-1}$ em meio SF 900 II no Contínuo 1, 3 e 5 . 123 


\section{Lista de Figuras}

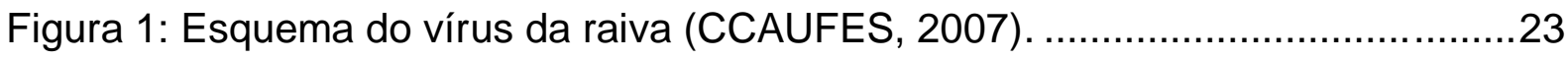

Figura 2: Mapa do vetor pAcGPV (Adaptado de YOKOMIZO et al., 2007) ...............24

Figura 3: Mapa do vetor pMtGPV (Adaptado de Lemos et al., 2009) .......................24

Figura 4: Esquema das principais vias metabólicas para a Sf9.............................25

Figura 5: Foto de células $\mathrm{CHO}$ aderidas aos microcarregadores. (fonte: Ventini,

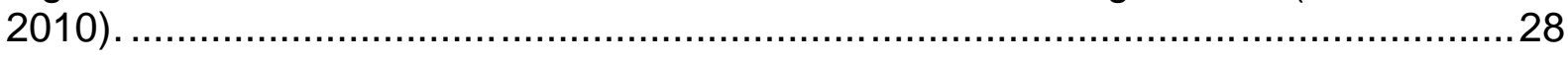

Figura 6: Exemplo de biorreatores: Tanque agitado e air lift................................28

Figura 7: Perfis de concentração de células e de substratos em processos realizados em biorreator com diferentes tipos de operação.

Figura 8: Shaker contendo células S2 no schotts com uma velocidade de agitação de 100rpm.

Figura 9: Foto do biorreator e seus acessórios para o funcionamento do processo

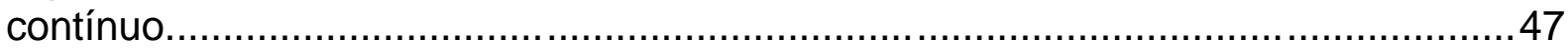

Figura 10: Fluxograma representando as entradas e saídas do processo contínuo. 47

Figura 11: Esquema ilustrando os testes realizados em schott com $\mathrm{CuSO}_{4}$

Figura 12: Fluxo metabólico da glutamina e do glutamato em células animais (DOVERSKOG et al., 1997). 


\section{Sumário}

INTRODUÇÃO

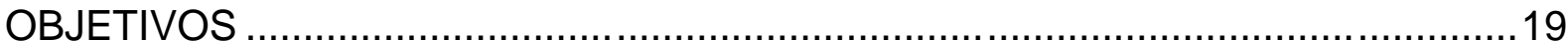

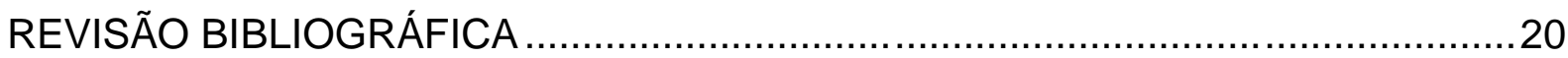

3.1 Células de Drosophila melanogaster (S2) ............................................20

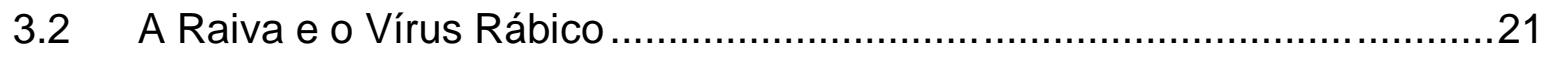

3.3 Linhagens de células S2 para expressão de gpv ....................................23

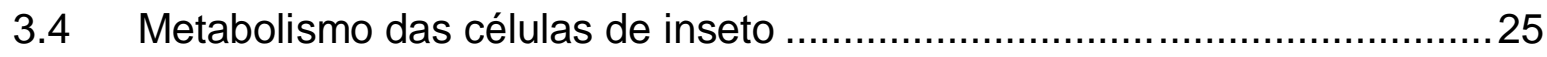

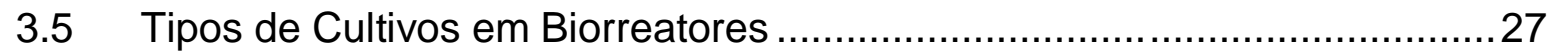

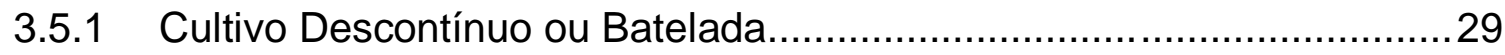

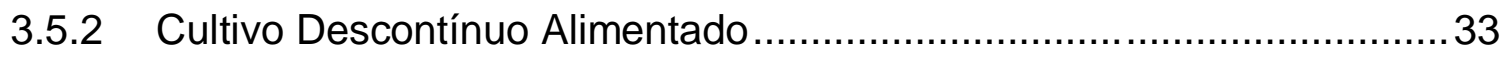

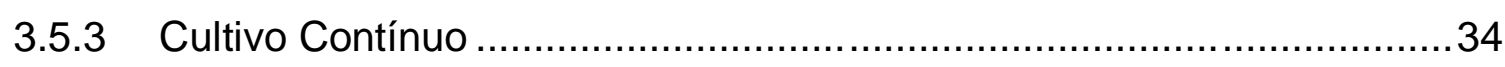

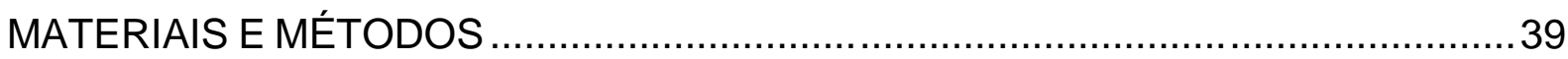

4.1 Linhagem Celular e Meio de Cultivo ......................................................39

4.2 Preparo do Banco de Células para Cultivos em Biorreator .........................41

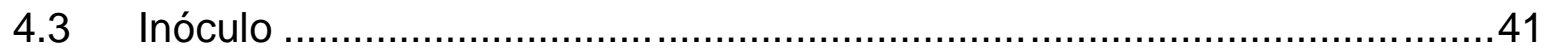

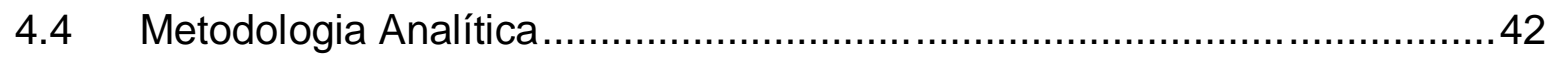

4.4.1 Concentração Celular e Viabilidade.................................................. 42

4.4.2 Glicose, Lactato, Glutamato e Glutamina .........................................43

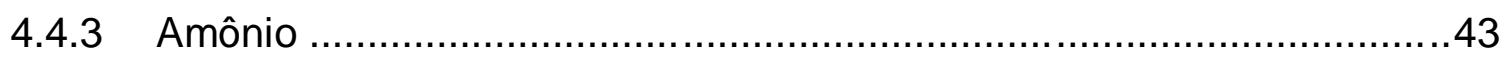

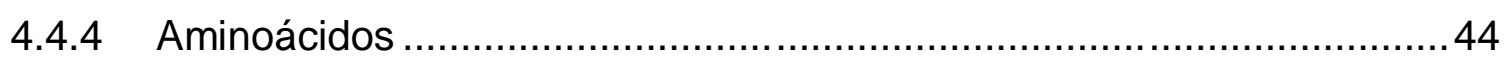

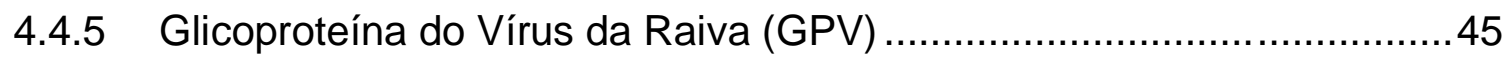

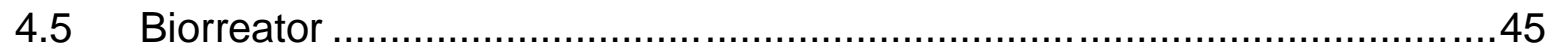

4.5.1 Ensaios em Biorreator em Regime Descontínuo ..................................48

4.5.2 Ensaios em Biorreator em Regime Contínuo.........................................48

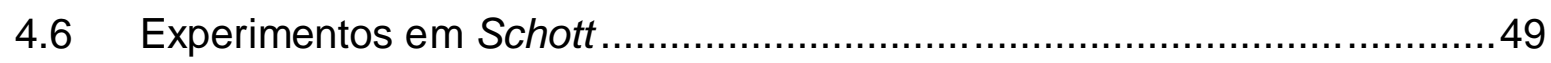

4.6.1 Testes com diferentes concentrações de Sulfato de Cobre...................49

4.6.2 Testes com diferentes concentrações de Glutamina .............................51

4.6.3 Testes com diferentes concentrações de Aminoácidos ............................51

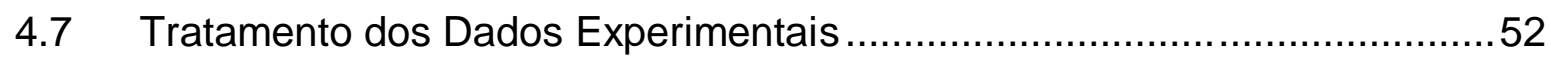

4.7.1 Determinação das velocidades específicas ........................................52

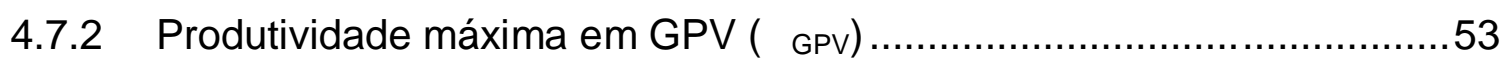

4.7.3 Cálculo dos Fatores de Conversão....................................................53

4.7.4 Equacionamento do Biorreator para o Processo Contínuo......................55

4.8 Análise estatística dos Experimentos realizados em Schott ........................56

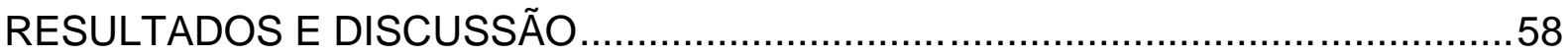




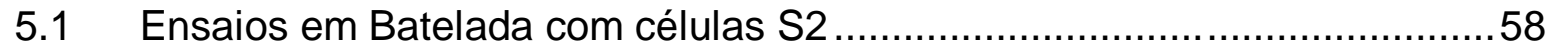

5.2 Ensaios em schott para testes com o Sulfato de Cobre $\left(\mathrm{CuSO}_{4}\right)$...............73

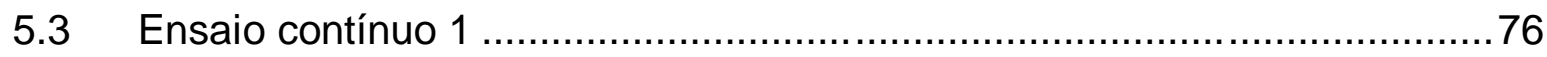

5.4 Ensaio em schott com diferentes concentrações de glutamina....................84

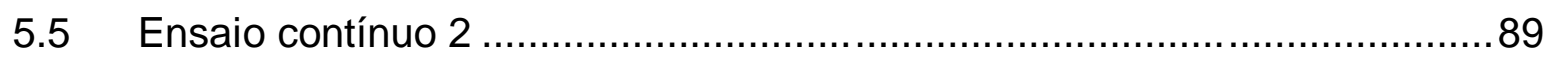

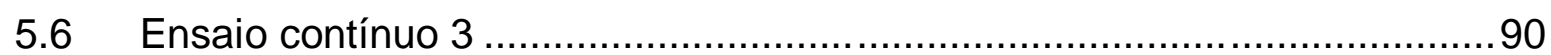

5.7 Ensaio em schotts com diferentes concentrações de aminoácidos ............99

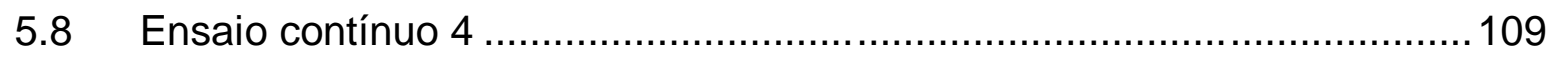

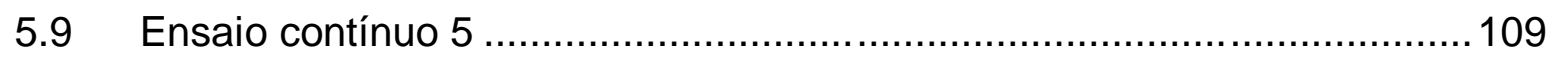

5.10 Comparação entre os ensaios contínuos................................................. 121

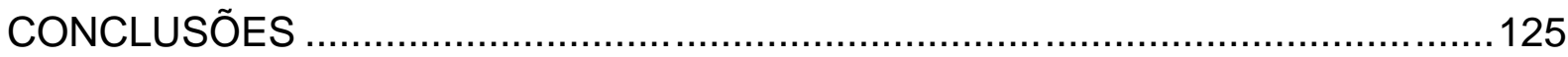

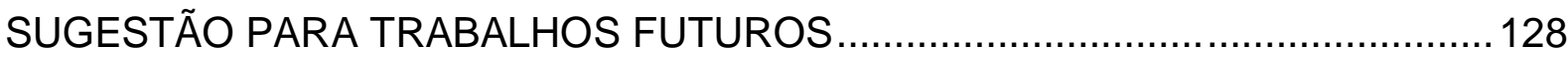

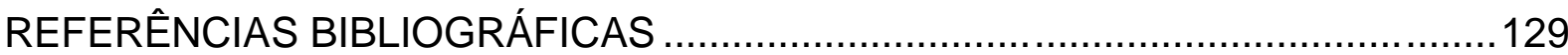




\section{INTRODUÇÃO}

A tecnologia de cultivos de células animais, como de mamíferos e insetos, vem sendo utilizada há aproximadamente 100 anos. O pioneiro em culturas de células animais foi Harrison em 1907, o qual cultivou células nervosas por um período de 30 dias (HARRISON et al., 1907). A partir desta data outros fatos importantes ocorreram, como por exemplo, a replicação do vírus da poliomielite em células HeLa para ser utilizado como vacina (ENDERS et al., 1949) e a formulação de meio de cultura quimicamente definido EMEM (meio mínimo essencial Eagle⿳⺈). Este último substituiu os fluidos biológicos e vem sendo utilizado até os dias hoje (EAGLES, 1955).

Nos últimos anos houve um maior número de biofármacos aprovados e produzidos através de culturas de células animais. Tal fato se deve a um aumento na demanda de alguns biofármacos e no avanço de tecnologias de cultivos de células. A literatura proporciona alguns casos, como a maior produção de anticorpos monoclonais produzidos a partir de células animais (BUTLER, 2005). Estes anticorpos são necessários em grandes doses para o uso terapêutico.

Butler (2005) menciona ainda outro fator que contribuiu para este avanço: a evolução da engenharia genética, a qual proporcionou modificações genéticas nas células a fim de expressar uma proteína específica e minimizar a formação de produtos ñndesejáveisò Ainda, a caracterização do metabolismo celular e da fisiologia da célula também permitiu considerável avanço na tecnologia de processos em biorreatores (DOVERSKOG et al., 1998).

Os processos de cultivo celular, em geral, podem ser divididos em dois grupos, de acordo com o tipo de célula utilizado: células aderentes, as quais necessitam de um suporte sólido, e células em suspensão, as quais se desenvolvem livremente no meio de cultura (PINTO et al., 2008). Os cultivos in vitro requerem cuidados específicos fundamentais para a sobrevivência celular, dependendo da espécie animal que originou a célula em questão, dos tecidos de origem ou ainda do grau de adaptação destas células a uma cultura.

Células de insetos, geralmente, são cultivadas em suspensão. As células são mantidas através de repiques sucessivos, ou seja, retirando-se o meio saturado 
com metabólitos e desprovido de nutrientes e, subsequentemente, adicionando-se meio fresco (BATISTA et al., 2008). Neste trabalho utilizou-se a linhagem celular S2 obtida da Drosophila melanogaster, a qual se trata de uma célula de inseto bastante utilizada na expressão de proteínas heterólogas.

O presente trabalho faz parte de um projeto temático da Fundação de Amparo à Pesquisa do Estado de São Paulo - FAPESP (02/09482-3) voltado para a obtenção de vacina contra a raiva através da clonagem dos genes da glicoproteína do vírus da raiva (GPV) em vetores de expressão nas células S2. O projeto envolve cinco instituições com interesse na pesquisa: o Instituto Butantan, a Universidade Federal de São Carlos, a Universidade Estadual de Campinas, o Instituto de Pesquisas Tecnológicas (IPT) e a Universidade de São Paulo (USP).

Neste projeto temático já foram estudadas diversas variáveis de cultivo em biorreatores, tais como temperatura, concentração de oxigênio dissolvido (OD), meios de cultura, frequência de agitação e $\mathrm{pH}$ para se obter altos rendimentos da proteína de interesse (GALESI et al., 2007; PAMBOUKIAN et al., 2008; BATISTA et al., 2009; MENDONÇA et al., 2008; SWIECH et al., 2008b; MENDONÇA et al., 2009 AGUIAR, 2010; VENTINI et al., 2010).

Até então, os cultivos para produção realizados no projeto ocorreram em processos em batelada ou batelada alimentada, ou seja, processos não contínuos de obtenção da proteína de interesse. Desta forma, a proposta central deste trabalho foi cultivar em processo contínuo células de inseto S2 para a produção de GPV.

Existem muitas vantagens do processo contínuo em relação ao processo em batelada, tais como a redução de tempos não produtivos, a obtenção de um produto uniforme, o controle da velocidade específica de crescimento celular, dentre outros (SCHIMIDELL, 2001). Porém, em escala laboratorial, pode-se destacar uma das principais vantagens de se cultivar células em processo contínuo e em quimiostato é a facilidade de realizar estudos da fisiologia da célula no estado estacionário, pois os parâmetros cinéticos do meio permanecem constantes ao longo do tempo (HAYTER et al., 1993). 


\section{OBJETIVOS}

O objetivo deste projeto foi avaliar o comportamento das células de inseto cultivadas em processo contínuo e identificar o nutriente limitante ou o subproduto inibitório do crescimento celular em meio SF 900 II. A partir dessas informações atingir altas concentrações celulares. Para tanto, foram utilizadas células de inseto de Drosophila melanogaster (S2) capazes de sintetizar a glicoproteína do vírus da raiva, a qual pode ser utilizada como vacina contra tal doença.

Como objetivos específicos, podem ser citados:

- Estabelecer no laboratório metodologia para cultivos contínuos de longa duração;

- Verificar a existência de estados estacionários em populações de células não idênticas. 


\section{REVISÃO BIBLIOGRÁFICA}

\subsection{CÉLULAS DE DROSOPHILA MELANOGASTER (S2)}

A Drosophila melanogaster é um inseto díptero pertencente ao gênero das moscas da fruta. Esta espécie é uma das mais utilizadas em experiências genéticas, sendo um dos mais importantes organismos modelo em Biologia. Há pelo menos 94 diferentes linhagens celulares de Drosophila cultiváveis, das quais cerca de doze são facilmente encontradas (ASHBURNER, 1989). A maioria dos estudos tem utilizado as linhagens Schneider S2 e S3, com o objetivo de expressão gênica (CHERBAS e CHERBAS, 1994). A linhagem Schneider S2 foi estabelecida a partir de culturas primárias embrionárias e é usada como hospedeiro em um sistema de expressão baseado na utilização de plasmídeos para a secreção de proteínas humanas funcionais (SCHNEIDER, 1972).

As células S2 como sistema de expressão recombinante possuem muitas vantagens em relação a outros microorganismos, tais como: (i) melhor glicosilação quando comparadas a leveduras e bactérias; (ii) crescem facilmente em temperaturas entre 22 e $27^{\circ} \mathrm{C}$; (iii) não necessitam de controle de $\mathrm{pH}$ e (iv) possibilitam ainda altos rendimentos de proteínas quando comparadas às células de mamíferos (SHIN e CHAO, 2002; SHIN, LIM e CHAO, 2003).

Uma característica singular das células de inseto S2 é a possibilidade de integração de mais de 1000 cópias do sistema de expressão em apenas um evento de expressão e seleção; não sendo necessário, portanto, um longo período para amplificação do plasmídeo e seleção das células clonadas para estabelecer uma linhagem celular com altos níveis de expressão do gene introduzido (DEML et al., 1999).

Dentre os antígenos virais, podemos destacar a glicoproteína do vírus da raiva que também é expressa por células S2, a qual foram geneticamente modificadas no Instituto Butantan por Yokomizo et al, 2007 e Lemos et al, 2009. 


\subsection{A RAIVA E O VÍRUS RÁBICO}

A Raiva, também conhecida como hidrofobia é uma doença letal causada por um vírus da família Lyssavirus. Segundo dados obtidos pelo Instituto Pasteur de São Paulo (2009), estimativas conservadoras indicam que a cada 10 a 15 minutos uma pessoa morre de raiva; e a cada hora, 1.000 pessoas recebem tratamento pósexposicão no mundo. O agente causador da raiva pode infectar várias espécies de mamíferos. A transmissão viral ocorre por mordedura de animais contaminados (BAHLOUL et al.,1998).

Os principais agentes transmissores da raiva são os mamíferos silvestres, devido à dificuldade de vaciná-los em massa. Atualmente, no Brasil, os morcegos são as principais fontes de estoque do vírus rábico, transmitindo a raiva não só para os animais domésticos, mas principalmente para herbívoros, como bovinos e eqüinos.

A doença causa comprometimento do sistema nervoso central, caracterizada inicialmente por ansiedade, inquietude, desorientação, alucinações e até convulsões. Outros sintomas acompanhantes são hipersalivação, contração involuntária dos músculos e hiperventilação. $\mathrm{Na}$ fase final, instala-se um quadro de paralisia progressiva ascendente e coma no final da evolução. A literatura médica internacional, até o ano 2000, registrou apenas três casos de indivíduos que apresentaram sintomas de infecção pelo vírus e sobreviveram (Manual técnico do Instituto Pauster, 2000). Em novembro de 2008, houve o primeiro caso de cura no Brasil.

A vacina da raiva protege as pessoas que foram expostas ao vírus seja por lambidas, mordidas ou arranhões provocados por animal contaminado com a doença. Após contato com animal com suspeita de contaminação, a vacina e o soro anti-rábico (tratamentos pós-exposição) devem ser administrados o mais rápido possível (Instituto Pauster, 2009).

As principais vacinas contra a raiva de uso humano são baseadas em vírus inativados propagados em diferentes substratos. Dentre elas podemos citar: a vacina Fuenzalida \& Palácios modificada, a vacina produzida em cultura de células diplóides humanas (HDCV), a vacina purificada produzida em culturas de células 
Vero (PVCV), a vacina purificada produzida em cultura de células de embrião de galinha (PCEV) e a vacina purificada produzida em embrião de pato (PDEV), além de outras. (Vacinas.org.br, 2010).

Embora o processo de fabricação da vacina anti-rábica tenha evoluído ao longo dos anos (SAKAMOTO et al., 1999), vacinas inativadas originárias de tecidos nervosos podem estar associadas a sérios efeitos colaterais neurológicos. Por esta razão, é desejável o desenvolvimento de vacinas eficientes que eliminem a possibilidade de tais efeitos colaterais e que possam ser produzidas sem a utilização de materiais de risco e com baixo custo. Uma das mais populares e promissoras alternativas para o desenvolvimento de novas vacinas é a utilização de genes do vírus da raiva clonados e expressos em cultura de células animais. Essa possibilidade é baseada no fato de que apenas uma simples proteína viral, a glicoproteína G (proteína de membrana, presente na superfície do vírus) ser suficiente para produzir resposta imune (SAKAMOTO et al., 1999).

Essa glicoproteína tem sido reconhecida como um antígeno capaz de induzir anticorpos neutralizantes do vírus, conferindo imunidade protetora contra a doença, resultando no interesse de produzi-la nos mais diversos sistemas de expressão conhecidos. A proteína já foi expressa em bactérias, leveduras e células animais (LATHE et al., 1984; KIENY et al., 1984; PREHAUD et al., 2003; MORIMOTO et al., 1992; KLEPFER et al., 1993; MOCHIZUKI et al., 1998).

A glicoproteína está inserida na membrana externa do vírus e organizada como um trímero na superfície viral (MAILLARD e GAUDIN, 2002). Na Figura 1 pode-se ver o esquema do vírus da raiva e a glicoproteína G. 


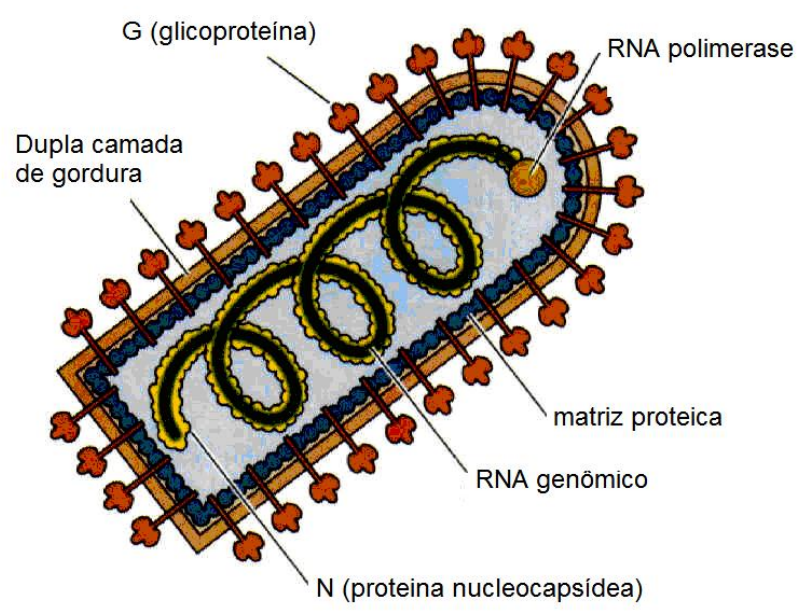

Figura 1: Esquema do vírus da raiva (CCAUFES, 2007).

A glicoproteína $(G)$ é uma proteína transmembrânica, a qual possui um domínio citoplasmático, um domínio transmembrânico e um ectodomínio (trímeros presentes na superfície viral). Ela possui peso molecular de aproximadamente 65 kDa ( 195 kDa o trímero) e é capaz de induzir resposta humoral neutralizante somente na forma trimérica.

\subsection{LINHAGENS DE CÉLULAS S2 PARA EXPRESSÃO DE GPV}

Os trabalhos disponíveis na literatura sobre o cultivo de células S2 são em sua grande maioria específicos para a linhagem de células geneticamente modificadas para a expressão de GPV. Existem duas linhagens para a célula S2 para expressão da GPV. Uma construção é com o promotor constitutivo da actina e outra com o promotor indutível metalotioneína (YOKOMIZO et al., 2007; LEMOS et al., 2009).

As células S2 transfectadas com o vetor pAcGPV (Figura 2) que expressam constitutivamente a glicoproteína $G$ do vírus da raiva foram denominadas de S2AcGPV (YOKOMIZO et al., 2007). Em 2007, pesquisadores do Laboratório de Imunologia Viral do Instituto Butantan isolaram uma sub-população da linhagem, a qual expressava quantidades entre 2 a 3 vezes superiores da proteína GPV, quando cultivada em meio SF 900 II. Embora este trabalho não tenha sido publicado, 
adotou-se como denominação para esta linhagem o termo S2AcGPV2K. Por isso, alguns trabalhos citam as células S2AcGPV como S2AcGPV-k ou S2AcGPV-2k.

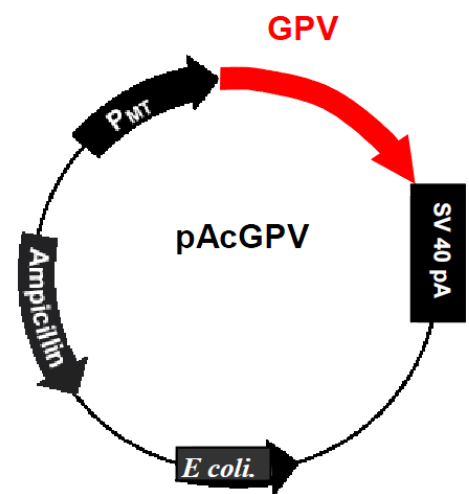

Figura 2: Mapa do vetor pAcGPV (Adaptado de YOKOMIZO et al., 2007)

As células S2 transfectadas com o vetor pMtGPV (Figura 3) que expressam a glicoproteína $\mathrm{G}$ do vírus da raiva foram denominadas de S2MtGPV (LEMOS et al., 2009).

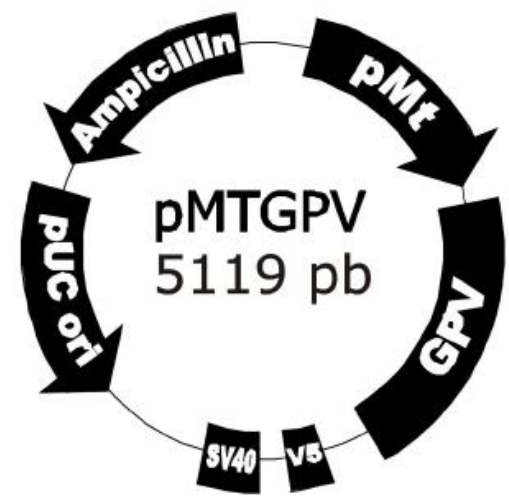

Figura 3: Mapa do vetor pMtGPV (Adaptado de Lemos et al., 2009)

O uso de células com vetores indutíveis permite controlar o período de início da expressão de um determinado gene pela indução do promotor. No caso das células S2MtGPV, utilizou-se o promotor indutível metalotioneina (Mt), o qual tem se mostrado capaz de expressar altos níveis de GPV quando induzido com o íon metálico $\mathrm{Cu}^{+2}$ (LEMOS et al., 2009).

Santos et al. (2007) determinaram que a concentração ideal de sulfato de cobre nas culturas para indução é igual a $700 \mu \mathrm{M}$, além de determinarem o melhor 
momento para realizar a indução, ou seja, quando a concentração celular atinge uma faixa entre 2 a $5 \times 10^{6} \mathrm{cel} / \mathrm{mL}$.

Vale lembrar que as células S2 selvagens foram estabelecidas a partir de um conjunto de culturas primárias embrionárias, portanto, estas células não são idênticas entre si (SCHNEIDER, 1972). Da mesma forma, as células S2 geneticamente modificadas não são clones e sim uma população heterogênea.

\subsection{METABOLISMO DAS CÉLULAS DE INSETO}

A maioria dos estudos do metabolismo de células de inseto refere-se a linhagens de lepidópteros, como a Sf9 de Spodoptera frugiperda (ÖHMAN et al., 1996).

Os compostos de maior importância para o cultivo de células de inseto são as fontes de carbono e nitrogênio, como glicose e glutamina e os produtos metabólicos: lactato, alanina e amônia. Na Figura 4, são mostradas as rotas metabólicas de consumo de glicose e glutamina e formação de lactato, de alanina e amônio para o cultivo de células Sf9.

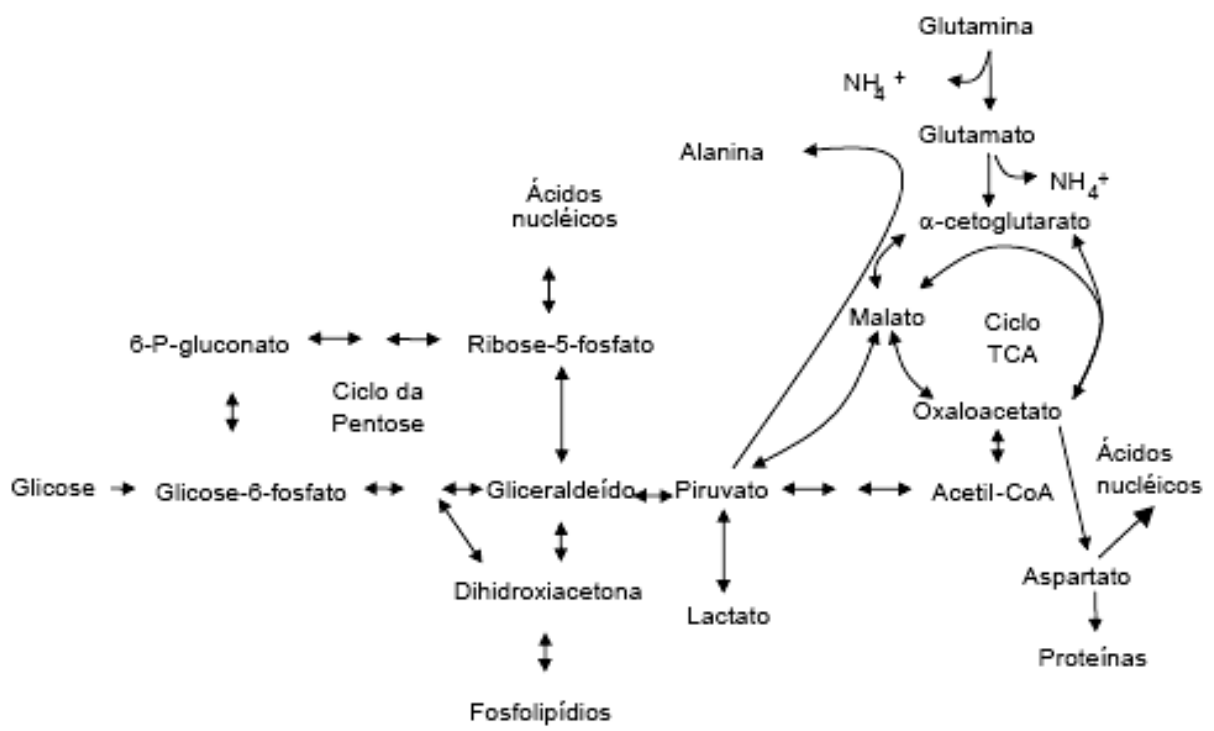

Figura 4: Esquema das principais vias metabólicas para a Sf9.

Adaptado de ÖHMAN et al., 1996 
O carboidrato mais usualmente consumido é a glicose, o qual é considerado a principal fonte de carbono para o crescimento celular (MENDONÇA et al., 1999). Seu principal metabólito é a alanina (DREWS; PAALME; VILU, 1995).

A glutamina consumida pode ser convertida em glutamato e amônio. Em alguns casos a glutamina pode ser sintetizada pelas próprias células em quantidades capazes de suprir o crescimento celular (ÖHMAN et al., 1996; BOVO et al., 2008).

Diferentemente da maioria das células de mamífero, o lactato é acumulado pelas células de inseto em baixos níveis, podendo ser produzido sob condições de estresse provocado pela limitação de oxigênio (IKONOMOU; SCHNEIDER; AGATHOS, 2003) ou ainda consumido para o suprimento de carbono ou energia para o metabolismo celular.

Quando ocorre limitação de glicose e glutamina no meio de cultivo observase pouca formação de alanina e amônio em célula Sf9 (DREWS et al., 2000; ÖHMAN et al., 1996; DOVERSKOG et al., 1997). Drews et al. (2000) mostram ainda que o metabolismo da glutamina pode depender das condições de cultivo, seguindo mais de uma via metabólica. Em situações de limitação de glicose, a glutamina é consumida normalmente pela glutaminólise, gerando amônio como principal subproduto. Entretanto, quando há excesso de glicose, a glutamina é metabolizada por intermédio da glutamato sintase (GOGAT ï glutamina 2-oxoglutarato amido transferase), de forma que o grupo amida da glutamina é transferido para a posição amina do glutamato que, posteriormente, é transaminado e, em vez de amônio, forma alanina, o principal subproduto desta via metabólica (DREWS et al.,2000).

Alguns trabalhos indicam que com a limitação de glicose, as células de insetos podem passar a consumir sacarose (GRACE, 1966; WANG; KWONG; BENTLEY, 1993) reduzindo a velocidade de crescimento. Assim, os elevados valores de consumo de glicose, ou outros intermediários da via glicolítica, sugerem a presença de uma via glicolítica e de um ciclo de Krebs bastante ativos (BHATIA et al., 1997).

Nas células Sf9 o excesso de amônio é excretado na forma de alanina, um subproduto não tóxico para as células (ÖHMAN et al., 1996). O metabolismo de carboidratos em células S2 é ainda desconhecido, porém estudos sugerem que a 
glicose seja a principal fonte de carbono (como na Sf9) e, provavelmente, a trealose seja um nutriente essencial para o crescimento desta linhagem celular (GUY, 1997).

Cultivos com células S2AcGPV que expressam a glicoproteína do vírus da raiva foram realizados por Galesi et al. (2008) em meio TC 100 modificado. Os autores não observaram limitação no crescimento celular por glicose ou glutamina quando as concentrações iniciais das mesmas foram de $10 \mathrm{~g} / \mathrm{L}$ e a $3,5 \mathrm{~g} / \mathrm{L}$, respectivamente. Porém, observou-se inibição do crescimento celular quando a concentração de amônio atingia valores entre 40 e $60 \mathrm{mg} / \mathrm{L}$. Ambos os fatos também foram observados por Aguiar (2010).

Cultivos em batelada realizados com células S2AcGPV no meio SF 900 II mostram que a limitação de glutamina determina o fim da fase exponencial de crescimento das células S2. Observou-se que as células saiam da fase exponencial de crescimento e ainda restava cerca de $5 \mathrm{~g} / \mathrm{L}$ de glicose, porém a concentração de glutamina era nula (BOVO et al., 2008; SWIECH et al., 2008a; BATISTA et al., 2008).

Swiech et al. (2008a) afirmam ainda que a prolina pode estar limitando o processo juntamente com a glutamina. Observou-se que a adição de $1 \mathrm{~g} / \mathrm{L}$ de prolina ao meio SF 900 II aumentou cerca de 50\% a velocidade específica máxima de crescimento celular. Rossi (2008) observou a cisteína como fator limitante de crescimento celular de células S2AcGPV.

Por outro lado, Pamboukian et al. (2008) observou que cultivos de S2 selvagem e da linhagem S2AcGPV em meio SF 900 II não são limitados nem pela glicose tampouco pela glutamina.

Como pode ser observado, os estudos analisados para orientar esta pesquisa indicam considerável grau de divergência de resultados com relação ao substrato que limita ou mesmo inibe o crescimento celular.

\subsection{TIPOS DE CULTIVOS EM BIORREATORES}

De forma similar aos cultivos microbianos, existem vários tipos de cultivos com células animais. Uma primeira classificação para determinar o tipo ideal de reator está condicionada à forma de cultivo de células (se em suspensão ou 
imobilizadas) (BUTTLER, 2004). No caso de células animais dependentes de ancoramento (imobilizadas), existe a necessidade de um suporte físico para crescimento, como por exemplo, garrafas ñRolleròou microcarregadores.

Assim o aumento de escala se faz pelo aumento da área do suporte, o que difere do cultivo de células em suspensão, o qual requer apenas o aumento de volume de meio. Outra forma de se manter as células imobilizadas é através de fibras ocas (ñhollow fiberò) (BUTTLER, 2004). A Figura 5 mostra células de mamíferos aderidas aos microcarregadores, que por sua vez, ficam suspensos no meio de cultivo.

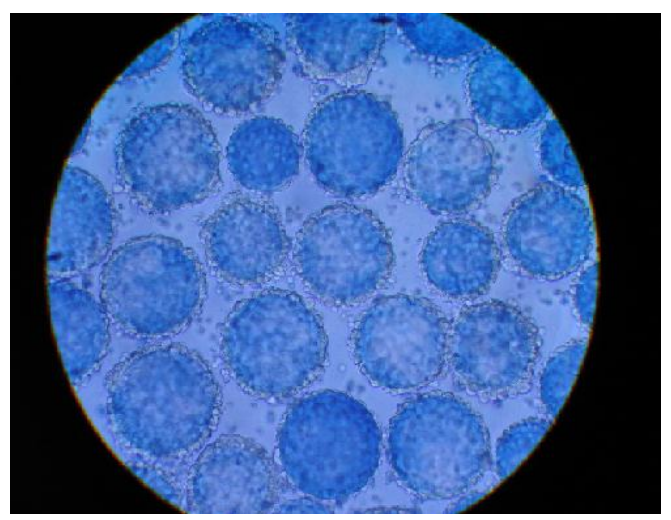

Figura 5: Foto de células $\mathrm{CHO}$ aderidas aos microcarregadores. (fonte: Ventini, 2010).

Para cultivos com células suspensas utilizam-se principalmente biorreatores do tipo tanque agitado, com ou sem algum esquema de separação de células, e em vários casos colunas de bolhas e reatores r̃air liftò como mostrado na Figura 6 (BUTTLER, 2004).
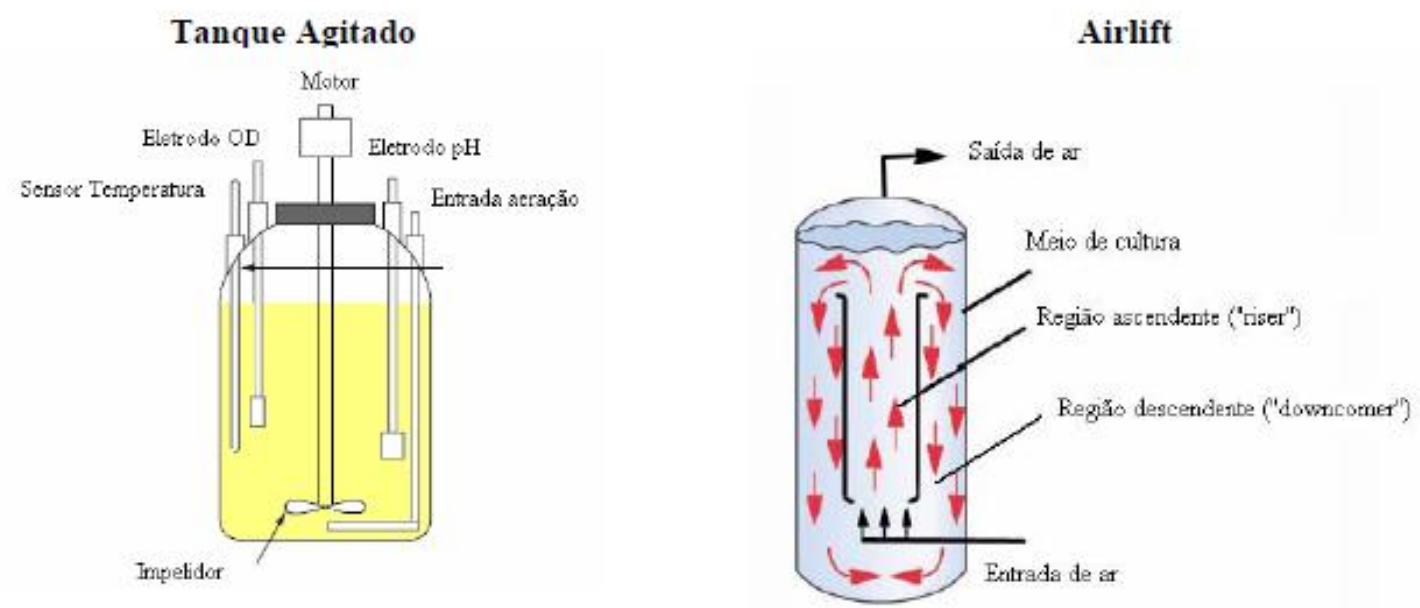

Figura 6: Exemplo de biorreatores: Tanque agitado e air lift 
Uma segunda classificação para escolha do tipo de processo empregado está relacionada à forma de condução do processo: descontínuo, descontínuo alimentado ou continuo. A Figura 7 mostra os perfis típicos das cinéticas de crescimento celular e de substrato residual ao longo da fermentação nos diferentes modos de operação.

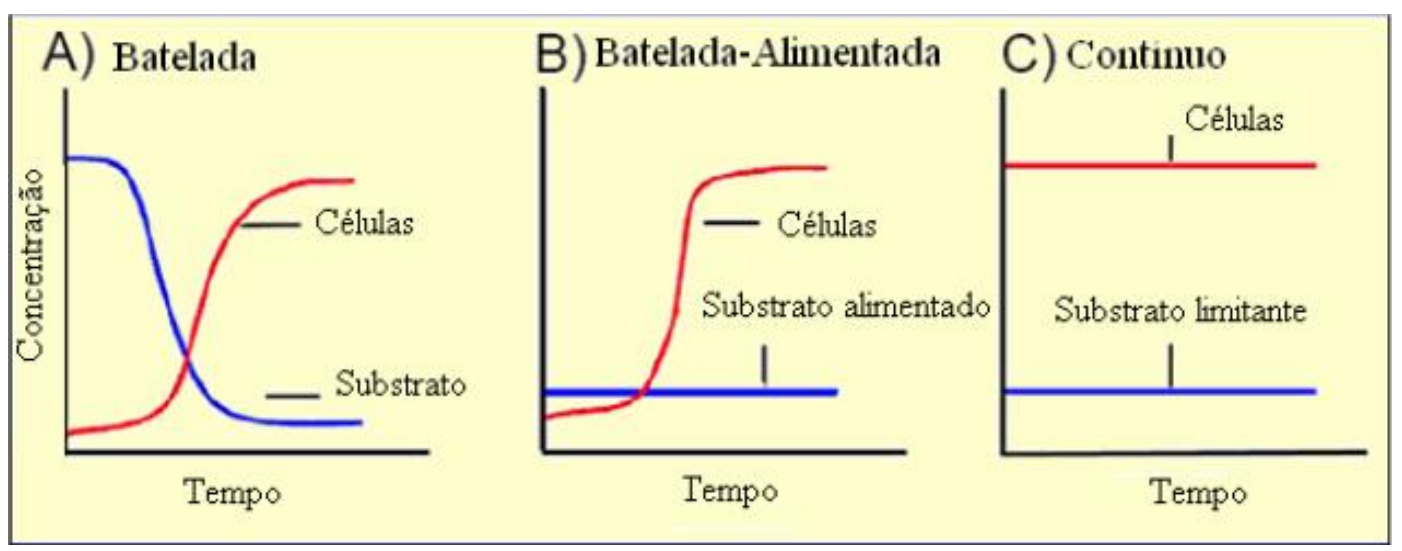

Figura 7: Perfis de concentração de células e de substratos em processos realizados em biorreator com diferentes tipos de operação.

Fonte: Swiech, 2007.

\subsubsection{Cultivo Descontínuo ou Batelada}

Neste tipo de cultivo, o biorreator é preenchido com o meio de cultura e então inoculado com células. Durante o cultivo não há suprimento de nutrientes ao meio, com exceção de oxigênio através da aeração devido à sua baixa solubilidade no meio de cultura.

Os cultivos descontínuos são mais utilizados devido à simplicidade, baixo custo e facilidade no aumento de escala. Apesar deste tipo de cultura ser limitado devido à exaustão de nutrientes principais ou acúmulo de subprodutos tóxicos, o cultivo em batelada, se iniciado com um meio de cultura adequadamente formulado, pode resultar em ótimos rendimentos com mínimo custo (VAUGH, 1999).

No cultivo descontínuo, a limitação de nutrientes e a inibição por algum metabólito produzido são consideradas os principais fatores para a morte celular na fase de declínio. Para tentar vencer os diferentes problemas decorrentes da limitação de nutrientes ou inibição de metabólitos foram desenvolvidos os cultivos do tipo descontinuo alimentado e contínuo. 
Em trabalhos anteriores, como Sondergaard (1996), células de Drosophila melanogaster (S2) que expressam o fator IX foram cultivadas em biorreator em batelada e batelada repetida (retirava-se $50 \%$ do volume $(1 \mathrm{~L}$ ) de meio fermentado, separava-se as células que retornavam para o reator com $1 \mathrm{~L}$ de meio fresco, processo repetido a cada 2-4 dias por 36 dias). O cultivo foi realizado em meio de

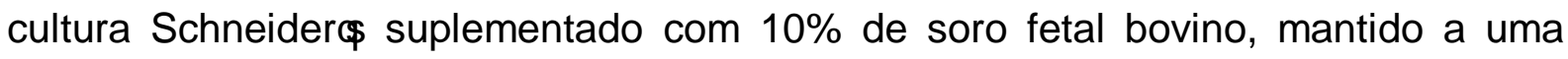
temperatura de $25 \pm 0,5^{\circ} \mathrm{C}$ numa agitação igual a $75 \mathrm{rpm}$ e $50 \%$ de oxigênio dissolvido. A maior concentração celular obtida foi no ensaio em batelada repetida de $29 \times 10^{6} \mathrm{cel} / \mathrm{mL}$. No processo em batelada alcançou-se uma concentração igual a $8,3 \times 10^{6} \mathrm{cel} / \mathrm{mL}$.

Células de Drosophila também foram cultivadas em biorreator por Pamboukian et al., 2008. Os autores cultivaram três linhagens diferentes: células S2 selvagens, células S2MtEGFP (geneticamente modificadas com o vetor indutível para expressão do gene da proteína verde fluorescente) e uma terceira linhagem de S2AcGPV, que expressam a glicoproteína do vírus da raiva. Todos os ensaios foram realizados em batelada em meio SF 900 II, a 28ํㅡ, 100 rpm e o oxigênio dissolvido controlado em $40 \%$ da saturação de ar (sistema livre de bolhas). A maior concentração celular obtida foi nas células S2 selvagens $\left(51,2 \times 10^{6} \mathrm{cel} / \mathrm{mL}\right)$ seguido das células S2AcGPV $\left(26,6 \times 10^{6} \mathrm{cel} / \mathrm{mL}\right)$ e das células S2MtEGFP $(17,8 \times$ $10^{6} \mathrm{cel} / \mathrm{mL}$ ). Porém, a maior velocidade específica de crescimento máxima calculada foi das células S2AcGPV com 1,26 dia ${ }^{-1}$, seguido das células S2 e S2MtEGPF com 1,07 $\mathrm{dia}^{-1}$ e 0,68 $\mathrm{dia}^{-1}$, respectivamente. No ensaio com células S2AcGPV, a concentração máxima de GPV produzida foi de $24 \mu \mathrm{g} / \mathrm{L}$ e o teor máximo de GPV foi $0,057 \mu \mathrm{g} / 10^{7}$ células.

Segundo Swiech (2007), para a obtenção de uma maior produção de GPV nas células S2AcGPV em meio SF 900 II a melhor estratégia está em utilizar $20 \%$ de concentração de oxigênio dissolvido e a uma temperatura sub-fisiológica à $22^{\circ} \mathrm{C}$, sob agitação de 100 a 120 rpm. A máxima concentração celular foi igual a 16,1 x $10^{6} \mathrm{cel} / \mathrm{mL}$ e $0 \mu_{x, \text { máx }}$ foi de $0,61 \mathrm{dia}^{-1}$. Porém, o teor de GPV foi igual a $0,075 \mu \mathrm{g} / 10^{7}$ células e a concentração foi de $120 \mu \mathrm{g} / \mathrm{L}$.

Swiech et al. (2008a) verificaram posteriormente o metabolismo de células S2 sob diferentes frequências de agitação e diferentes concentrações de aminoácidos no meio. Foram realizados 4 ensaios em biorreator, 3 em batelada e 
um em batelada alimentada. Todos os experimentos foram a $28^{\circ} \mathrm{C}$ e com $50 \%$ de oxigênio dissolvido.

As descrições dos ensaios estão na Tabela 1 (retirada de SWIECH et al., 2008b). A maior concentração celular alcançada foi no ensaio Bio-4 de $23 x$ $10^{6} \mathrm{cel} / \mathrm{mL}$, seguido do Bio-1 e Bio-3 com concentrações celulares iguais a 18,8 x $10^{6} \mathrm{cel} / \mathrm{mL}$ e $17,6 \times 10^{6} \mathrm{cel} / \mathrm{mL}$, respectivamente. Porém, a máxima velocidade específica de crescimento ( $\left.\mu_{x, \text { máx }}\right)$ ocorreu em Bio-2 $\left(2,1 \mathrm{dia}^{-1}\right)$, ou seja, o ensaio suplementado com prolina. O ensaio Bio-4 alcançou um $\mu_{x, m a ́ x}$ igual a 1,4 dia ${ }^{-1}$ e Bio1 igual a $1,15 \mathrm{dia}^{-1}$. Os resultados de Bio-3 são mostrados no item 3.4.2. Com relação à produção de GPV, os ensaios Bio-1 (138,7 $\mu \mathrm{g} / \mathrm{L})$ e Bio-4 (178,1 $\mu \mathrm{g} / \mathrm{L})$ alcançaram as concentrações mais elevadas. Já Bio-2, apesar de ter alcançado um $\mu_{x, \text { máx }}$ alto, a concentração de GPV foi baixa em relação aos outros $(29,4 \mu \mathrm{g} / \mathrm{L})$. Pode-se concluir que a melhor condição para a produção de GPV ocorreu no ensaio Bio-4, ou seja, com uma freqüência de agitação constante e no meio SF 900 II sem suplementos.

Tabela 1: Descrição dos ensaios com células S2AcGPV realizados por Swiech et al., 2008b.

\begin{tabular}{|c|c|}
\hline Ensaio & Descrição \\
\hline Bio-1 & $\begin{array}{l}\text { Batelada, com aumento da velocidade de agitação ( } 15 \mathrm{rpm} / \mathrm{dia}) \text { de } 100 \text { a } 240 \mathrm{rpm} \text {. Meio } \\
\text { de cultura SF } 900 \text { II }\end{array}$ \\
\hline Bio-2 & $\begin{array}{l}\text { Batelada, com aumento da agitação ( } 15 \mathrm{rpm} / \mathrm{dia} \text { ) de } 100 \text { a } 240 \mathrm{rpm} \text {. Meio de cultura SF } \\
900 \text { II suplementado com } 1 \mathrm{~g} / \mathrm{L} \text { de prolina. }\end{array}$ \\
\hline Bio-3 $^{*}$ & $\begin{array}{l}\text { Batelada alimentada, } \mathrm{F}=4 \mathrm{~mL} / \mathrm{h}, V_{0}=800 \mathrm{~mL} \text { e } V_{f}=1400 \mathrm{~mL} \text {. Aumento da frequência } \\
\text { de agitação, iniciando com } 100 \mathrm{rpm} \text { e aumentando } 8 \mathrm{rpm} / \text { dia até o } 4^{\circ} \text { dia, depois } \\
30 \mathrm{rpm} / \text { dia nos últimos } 2 \text { dias. Meio de cultura SF } 900 \mathrm{II}+1,8 \mathrm{~g} / \mathrm{L} \text { Prolina }+0,06 \mathrm{~g} / \mathrm{L} \\
\text { Serina }+1,25 \mathrm{~g} / \mathrm{L} \text { Glutamina }+0,001 \mathrm{~g} / \mathrm{L} \text { Cisteína. }\end{array}$ \\
\hline Bio-4 & Batelada, frequência de agitação constante e igual a 150 rpm. Meio de cultura SF 900 ॥I \\
\hline
\end{tabular}

Galesi et al. (2008) também avaliaram a influência da frequência de agitação (50 ï 150 rpm) em cultivos em biorreatores em modo batelada, porém em meio 
TC100 adaptado por Galesi et al. (2007). A concentração ideal de Pluronic F68®, que é um estabilizante contra o cisalhamento celular, também foi avaliada $(0,1$ ï $0,6 \% \mathrm{w} / \mathrm{v})$. Foram observados que os ensaios com maior velocidade de agitação, tais como 100 e 150 rpm, apresentaram uma menor velocidade específica de crescimento máxima quando comparadas a ensaios com frequência de agitação mais baixa. O ensaio com frequência de agitação em 90 rpm, 30\% de oxigênio dissolvido e $0,3 \% \mathrm{w} / \mathrm{v}$ de Pluronic $\mathrm{F} 68 \AA$ obteve um maior $\mu_{x, \text { máx }}$ de $0,792 \mathrm{dia}^{-1} \mathrm{e}$ alcançou uma concentração celular igual a $9 \times 10^{6} \mathrm{cel} / \mathrm{mL}$, além de uma concentração de GPV de aproximadamente $100 \mu \mathrm{g} / \mathrm{L}$.

Esta concentração alcançada foi inferior a concentração encontrada por Swiech et al. (2008b), porém em relação ao teor de GPV alcançado, Galesi et al. (2008) obtiveram valores superiores.

Rossi (2008) analisou o comportamento de células S2AcGPV em diferentes temperaturas de cultivos em meio SF 900 II suplementado com 1,94 g/L de prolina, 2,35 $\mathrm{g} / \mathrm{L}$ de glutamina, $0,0134 \mathrm{~g} / \mathrm{L}$ de cisteína, $0,132 \mathrm{~g} / \mathrm{L}$ de serina e 0,066 $\mathrm{g} / \mathrm{L}$ de asparagina. As temperaturas nos cultivos variaram de 20 a $28^{\circ} \mathrm{C}$. O ensaio que apresentou maior valor de $\mu_{x \text {,máx }}\left(1,46 \mathrm{dia}^{-1)}\right.$ foi o ensaio com a temperatura de $28^{\circ} \mathrm{C}$, porém a maior concentração celular $\left(31 \times 10^{6} \mathrm{cel} / \mathrm{mL}\right)$ e a maior concentração de GPV foi no ensaio no qual houve uma gradual diminuição da temperatura de $20^{\circ} \mathrm{C}$ para $16^{\circ} \mathrm{C}$. A concentração de GPV deste ensaio foi igual a $567 \mu \mathrm{g} / \mathrm{L}$, aproximadamente 3,5 vezes maior que no ensaio a $28^{\circ} \mathrm{C}$.

Ventini et al. (2010) compararam as células S2AcGPV com as células S2MtGPV em meio SF 900 II. Os autores concluíram que os melhores resultados para a produção de GPV são com as células S2MtGPV a 10\% de oxigênio dissolvido a $28^{\circ} \mathrm{C}$ de temperatura, em uma agitação de $90 \mathrm{rpm}$. Nestas condições pode-se produzir $3000 \mu \mathrm{g} / \mathrm{L}$ de GPV com uma concentração celular máxima de $18 \times 10^{6}$ $\mathrm{cel} / \mathrm{mL}$.

Aguiar (2010) indicou que a condição ótima para a produção de GPV em células S2AcGPV foi obtida para uma concentração de oxigênio dissolvido equivalente a $30 \%$ e a uma temperatura de $28^{\circ} \mathrm{C}$. O meio estudado foi o TC $100 \mathrm{com}$ $10 \mathrm{~g} / \mathrm{L}$ de glicose e $3,5 \mathrm{~g} / \mathrm{L}$ de glutamina. Nestas condições foi observada uma produtividade de 9,1 $\mu \mathrm{g} / \mathrm{L}$.h e concentrações de GPV de $1200 \mu \mathrm{g} / \mathrm{L}$. 
Esses últimos dois trabalhos foram os que apresentaram maiores concentrações da glicoproteína do vírus da raiva.

\subsubsection{Cultivo Descontínuo Alimentado}

Se comparado ao cultivo descontínuo, no qual o crescimento celular é limitado pela falta de nutrientes, o cultivo descontínuo alimentado tem como idéia principal suplementar o meio com nutrientes durante o cultivo visando aumentar a quantidade de células viáveis no meio e, consequentemente, um maior rendimento celular. Nesse tipo de cultivo, os nutrientes limitantes são adicionados ao meio durante o curso da fermentação.

Diferentemente do contínuo, o meio de cultura do processo não é retirado, ocorrendo gradualmente acúmulo de metabólitos. Os nutrientes adicionados ao processo deverão ser ajustados para que não ocorra uma formação de metabólitos que seja inibitório para o crescimento celular ou até mesmo causem morte celular (GRIFFITHS , 1992).

A literatura fornece alguns resultados para o cultivo de células S2 em batelada alimentada, como Swiech et al. (2008b). Os autores cultivaram células S2AcGPV em meio SF 900 II suplementado com aminoácidos em batelada alimentada com uma vazão de alimentação igual a $4 \mathrm{~mL} / \mathrm{h}$, conforme mostrado na Tabela 1. A máxima concentração celular alcançada foi de $23,1 \times 10^{6} \mathrm{cel} / \mathrm{mL}$, ou seja, igual ao valor alcançado na batelada com o meio SF 900 II puro. A máxima concentração de GPV neste ensaio foi de $140 \mu \mathrm{g} / \mathrm{L}$.

Rossi (2008) também realizou ensaios em batelada alimentada em meio suplementado com aminoácidos $(1,94 \mathrm{~g} / \mathrm{L}$ de prolina, 2,35 g/L de glutamina, 0,0134 $\mathrm{g} / \mathrm{L}$ de cisteína, 0,132 $\mathrm{g} / \mathrm{L}$ de serina e 0,066 $\mathrm{g} / \mathrm{L}$ de asparagina), porém com concentrações diferentes da utilizada por Swiech et al. (2008b). As células foram cultivadas a $20^{\circ} \mathrm{C}, 150 \mathrm{rpm}, \mathrm{pH}$ igual a 6,2 e $50 \%$ de oxigênio dissolvido. O volume inicial do reator foi $850 \mathrm{~mL}$ e ao meio de alimentação foram adicionados mais $0,86 \mathrm{~g} / \mathrm{L}$ de cisteína e 7,4 g/L de serina. O ensaio foi interrompido no $7^{\circ}$ dia por contaminação, porém até este momento, a concentração celular alcançada foi 24,3 x 
$10^{6} \mathrm{cel} / \mathrm{mL}$ e a concentração de GPV atingida foi $1156 \mu \mathrm{g} / \mathrm{L}$, bem elevada quando comparada aos experimentos em batelada com essas células.

\subsubsection{Cultivo Contínuo}

Neste tipo de cultivo, meio estéril é adicionado continuamente ao biorreator com remoção simultânea de um volume igual de meio contendo células e metabólitos. Este modo de alimentação prolonga o cultivo e permite que uma maior produtividade seja alcançada.

O cultivo contínuo inicia-se a partir de um cultivo em batelada. O processo é denominado contínuo a partir do momento em que se inicia a alimentação de meio e a retirada do caldo. Este processo se caracteriza por atingir um estado estacionário, no qual as variáveis como concentração celular, concentração de substrato e produto são mantidas constantes no biorreator ao longo do tempo, o que exige que as vazões de alimentação e de retirada sejam as mesmas (COSTA, 2008).

Deve-se lembrar que a concentração celular alcançada no estado estacionário em quimiostato permanece constante devido à limitação de nutrientes indispensáveis para o crescimento, caso contrário, a concentração celular aumentaria com tempo. Este nutriente é denominado de substrato limitante. Ou seja, a concentração celular é controlada pelo residual do substrato limitante, o qual determina o equilíbrio entre crescimento e lavagem (TONSO, 2000).

Desse fato decorre a importância em conhecer o substrato limitante, pois um acréscimo na sua concentração no meio de alimentação resulta em um aumento na concentração celular até que se atinja um novo estado estacionário.

Os cultivos contínuos podem ou não ter reciclo de células. As concentrações máximas celulares alcançadas quando há reciclo são maiores que no cultivo contínuo simples. Cultivos contínuos com reciclo de células são denominados perfusão contínua (TONSO, 2000). O fator de coagulação VIII, licenciado pela Bayer, foi o primeiro biofármaco recombinante produzido por células $\mathrm{BHK}$ a partir da cultura de perfusão contínua (KRETZMER, 2002).

A tabela 2 mostra as principais vantagens e desvantagens do processo contínuo em relação ao processo descontínuo, adaptado de Facciotti, 2001. 
Tabela 2: Vantagens e desvantagens do processo contínuo com relação ao descontínuo.

\begin{tabular}{l|l}
\hline \multicolumn{1}{c|}{ VANTAGENS } & \multicolumn{1}{c}{ DESVANTAGENS } \\
\hline $\begin{array}{l}\text { Redução dos tempos m̃mortosò ou não } \\
\text { produtivos. }\end{array}$ & $\begin{array}{l}\text { Dificuldade de manutenção de condições de } \\
\text { assepsia por longos períodos de tempo. }\end{array}$ \\
\hline $\begin{array}{l}\text { Obtenção de produto uniforme. } \\
\text { Possibilidade de ocorrência de mutações } \\
\text { genéticas espontâneas. }\end{array}$ \\
$\begin{array}{l}\text { fisiológico (controle de } \varepsilon \text { ) } \\
\text { Maior facilidade de controles automáticos } \\
\begin{array}{l}\text { avançados e menor necessidade de mão-de- } \\
\text { obra. }\end{array}\end{array}$ & $\begin{array}{l}\text { Dificuldade de manutenção dos estados } \\
\text { estacionários em determinadas situações, tais } \\
\text { como formação de espuma e de crescimento } \\
\text { celular na parede ao longo do tempo. }\end{array}$ \\
\hline $\begin{array}{l}\text { Possibilidade de associação com outras nábrica. } \\
\text { operações contínuas numa linha de produção. }\end{array}$ & $\begin{array}{l}\text { Dificuldade de manutenção de homogeneidade } \\
\text { no biorreator, quando se trabalha com baixas } \\
\text { vazões ou quando se tem meio muito viscoso. }\end{array}$ \\
\hline
\end{tabular}

Adaptada de Facciotti, 2001.

As vantagens e desvantagens mostradas na tabela anterior são relacionadas à produção industrial. Em escala laboratorial ou de pesquisa, a técnica para processos contínuos tem sido utilizada para o estudo da fisiologia das células animais. Culturas em quimiostato permitem este estudo da fisiologia da célula, pois os parâmetros permanecem constantes ao longo do tempo quando atingido o estado estacionário. Tal característica difere de processos em batelada, nos quais ocorrem mudanças nos parâmetros de crescimento celular a todo instante (HAYTER et al., 1993).

Não existem critérios determinados para se afirmar que o estado estacionário foi atingido. Hayter et al. (1991) cultivaram uma linhagem de células $\mathrm{CHO}$ que expressam interferon- $\neq$ humano recombinante (IFN-כ) em processo contínuo (quimiostato) com o objetivo de examinar o efeito do meio na fisiologia da célula e na glicosilação do IFN-כ em estado estacionário. Para tal, foi mantida uma vazão específica de alimentação constante $\left(D=0,36\right.$ dia $\left.^{-1}\right)$ e a concentração de glicose variada no meio de alimentação (2,75 mM e 4,25 mM). Foi observado que um aumento de 1,5 vezes na concentração de glicose aumentou 1,5 vezes a 
concentração celular, indicando que $2,75 \mathrm{mM}$ de glicose limitavam o processo. Porém, um aumento na concentração de glicose causou uma diminuição na produtividade da proteína e também na quantidade de proteínas glicosiladas corretamente.

Os autores concluíram que houve uma alteração na fisiologia das células ao longo do cultivo, o qual durou cerca de 100 dias. Vale ressaltar que as diferenças entre os estados estacionários foram consideradas significantes quando o $p$-valor foi menor que 0,05. Ou seja, os valores são expressos dentro de um limite de $95 \%$ de confiança.

O mesmo grupo (HAYTER et al.,1993) posteriormente estudou em quimiostato os efeitos das vazões específicas de alimentação (D) na fisiologia das células $\mathrm{CHO}$ que expressam o IFN-כ com o intuito de identificar os fatores que influenciam a glicosilação da proteína de interesse. As taxas de diluição variaram de 0,2 a $0,48 \mathrm{dia}^{-1}$, sabendo que o $\mu_{x, \text { máx }}$ calculado foi de $0,52 \mathrm{dia}^{-1}$. Com relação ao metabolismo celular, pode-se destacar que mesmo com o aumento da taxa de diluição, os fatores de conversão glicose a células permaneceram constantes ao logo do tempo. Foi observado também que a produtividade da proteína aumenta com o aumento da taxa de diluição, indicando que a velocidade de produção está relacionada à velocidade crescimento celular.

Os autores mostram que a glicosilação padrão da proteína permanece constante numa ampla faixa de condições fisiológicas, mas é alterada quando a taxa de diluição é baixa. Frisa-se ainda que os autores assumiram que o processo só alcança o estado estacionário após cinco tempos de residência.

Ensaios contínuos com hibridomas para a produção de anticorpo monoclonal (lgG2a) foram cultivados por Hiller et al. (1993). A vazão específica de diluição

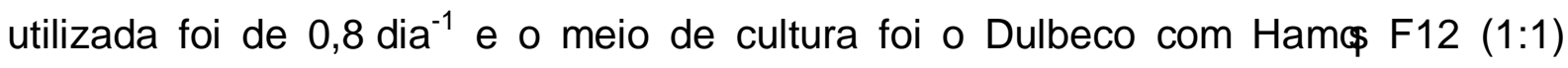
suplementado com glicose e glutamina. Para analisar os efeitos dos aminoácidos e de vitaminas sobre o metabolismo celular, ao longo dos ensaios, vários estados estacionários foram alcançados com diferentes concentrações de aminoácidos no meio de alimentação. Os substratos testados foram: Cisteína e Metionina; Histidina; Leucina e Lisina; Vitamina B6; Isoleucina, Valina e $\mathrm{B}_{12}$; Triptofano; Triosina, Fenilalanina e Ácido ascórbico; Cisteína, Metionina, Histidina, Leucina, Lisina, B6, Isoleucina, Valina e $\mathrm{B}_{12}$. Os autores concluíram que a adição de triptofano; de 
isoleucina e valina tiveram um efeito positivo na concentração de células viáveis. Foi observado também que as concentrações de cisteína e metionina adicionadas foram inibitórias logo após a adição, porém a concentração celular depois de atingido o estado estacionário foi, aproximadamente, $20 \%$ maior que na condição realizada com o meio puro. O estado estacionário foi assumido quando a concentração celular, a viabilidade, o consumo de oxigênio e glicose residual não variaram apreciavelmente por 3 dias.

Estudos voltados para a produção do hormônio eritropoietina a partir de células $\mathrm{CHO}$ foram realizados em processo contínuo com reciclo de células (perfusão) em turbidostato. Ou seja, a concentração de glicose foi mantida constante através de um controle externo ao sistema, no entanto a concentração de células não se manteve constante ao longo do cultivo (WANG et al., 2002). Os autores assumiram que o estado estacionário foi alcançado quando a concentração de glicose na saída permaneceu constante Segundo os mesmos autores, embora o metabolismo das células $\mathrm{CHO}$ geralmente varie durante culturas com longo prazo de perfusão, as concentrações de metabólitos se mantiveram constantes através de uma vazão fixa de perfusão.

A mesma condição para a determinação do estado estacionário foi relatada por Meuwly et al. (2006), em um estudo com vazão de perfusão constante no desenvolvimento de um processo de produção do mesmo hormônio (Eritropoietina).

Processos em culturas contínuas foram realizados com células BHK, nos quais foram determinados vários estados estacionários alterando-se as concentrações de glicose e de glutamina do meio de cultura na alimentação (CRUZ et al., 1999). O principal objetivo deste trabalho foi estudar o efeito de baixas concentrações de substratos residuais, como glicose e glutamina, no metabolismo celular. Os autores concluíram que baixas concentrações de substratos (glicose menor que $0,4 \mathrm{mM}$ e glutamina menor que $0,15 \mathrm{mM}$ ) causam mudanças significativas no metabolismo celular.

Como já mencionado, diversos cultivos com células de mamíferos foram realizados em processo contínuo ou em perfusão. Feng et al. (2006) cultivaram uma linhagem celular de hibridoma em perfusão para a produção do antibiótico monoclonal. Lee et al.(2008) realizaram cultivos de células $\mathrm{CHO}$ recombinantes em 
perfusão para a produção de um anticorpo monoclonal contra o antígeno de superfície do vírus da hepatite $B$.

Por outro lado, cultivos com células de inseto, o mais comum verificado na literatura são cultivos de células de inseto como sistemas de expressão de proteínas utilizando Baculovírus como vetor (Baculovirus Expression System (BEVs)). Esta técnica tem sido intensamente aplicada para produção de proteínas recombinantes em processos contínuos (PIJLMAN et al., 2004).

Pijlman et al. (2004) utilizaram as células de Spodoptera exígua Se301, em meio TNM-FH à $28^{\circ} \mathrm{C}$. Seu sistema contínuo consistiu de um reator com $1,5 \mathrm{~L}$ de volume de útil para o crescimento celular, o qual estava conectado a dois reatores menores (com 0,75 L de volume útil cada) destinados para a infecção com o vírus e, consequentemente, a produção da proteína desejada. O reator foi operado continuamente com um $\mathrm{D}=0,33 \mathrm{dia}^{-1}$ por mais de um mês. $\mathrm{O}$ estado estacionário foi considerado alcançado em 2,6 tempos de residência quando a concentração celular medida era de $25 \times 10^{6} \mathrm{cel} / \mathrm{mL}$ (o artigo não cita os critérios em que foi baseado o alcance do estado estacionário).

Por fim, células de Spodoptera frugiperda (Sf9) cultivadas em perfusão por 43 dias atingiram no estado estacionário concentrações celulares de 18 a $22 \times 10^{6}$ $\mathrm{cel} / \mathrm{mL}$. A produtividade da proteína de interesse obtida neste processo foi oito vezes maior do que aquela alcançada em processos em batelada. Com relação à concentração celular, a máxima concentração celular alcançada na batelada foi de $12 \times 10^{6} \mathrm{cel} / \mathrm{mL}$, ou seja, cerca de 1,8 vezes menor que em perfusão (JARDIN et al., 2007).

A literatura analisada para este trabalho (nacional e internacional) não indica estudos anteriores baseados em experimentos com cultivos contínuos usando células S2. 


\section{MATERIAIS E MÉTODOS}

\subsection{LINHAGEM CELULAR E MEIO DE CULTIVO}

Foram utilizadas duas linhagens celulares de Drosophila melanogaster (S2) transformadas com o gene da glicoproteína do vírus da raiva, sendo uma delas a linhagem constitutiva (S2AcGPV-2K) (YOKOMIZO et al., 2007) e a outra a linhagem indutível (S2MtGPV) (LEMOS et al., 2009). Ou seja, os vetores genéticos permitem a expressão gênica na forma constitutiva ou na indutiva. Ambas as linhagens foram cedidas pelo Laboratório de Imunologia Viral (LIV) do Instituto Butantan.

Vale ressaltar que as células S2AcGPV-2k também são conhecidas por S2AcGPV. Para este trabalho foi adotado o nome da linhagem de S2AcGPV.

As células S2 foram cultivadas no meio de cultura SF 900 II SFM (Invitrogen), cuja composição não é fornecida pelo fabricante. A concentração de parte dos componentes do meio está apresentada na Tabela 3 é referente às análises realizadas ao longo do trabalho e dados encontrados na literatura.

Foram realizadas seis dosagens do meio SF 900 II e o coeficiente de variação desta análise calculado foi de $9 \%$. 
Tabela 3: Concentração de parte dos componentes do meio SF 900 II utilizado neste trabalho.

\begin{tabular}{|c|c|c|}
\hline Componentes & Concentração (g/L) & Referência \\
\hline \multicolumn{3}{|c|}{ Açúcares } \\
\hline \multirow{2}{*}{ Glicose } & 9,500 & Este trabalho \\
\hline & 10,000 & Swiech, 2007 \\
\hline Sacarose & 2,000 & Swiech, 2007 \\
\hline \multirow{2}{*}{ Maltose } & 1,200 & Swiech, 2007 \\
\hline & 1,260 & Radford et al., 1997 \\
\hline \multicolumn{3}{|c|}{ Aminoácidos } \\
\hline Alanina & 0,360 & Swiech, 2007 \\
\hline \multirow{2}{*}{ Arginina } & 2,217 & Este trabalho \\
\hline & 0,330 & Swiech, 2007 \\
\hline \multirow{2}{*}{ Aspargina } & 1,060 & Este trabalho \\
\hline & 1,100 & Swiech, 2007 \\
\hline Aspartato & 1,161 & Este trabalho \\
\hline \multirow{2}{*}{ Cisteína } & 0,131 & Este trabalho \\
\hline & 0,045 & Swiech, 2007 \\
\hline \multirow{2}{*}{ Fenilalanina } & 0,947 & Este trabalho \\
\hline & 0,870 & Swiech, 2007 \\
\hline \multirow{2}{*}{ Glicina } & 0,720 & Este trabalho \\
\hline & 0,570 & Swiech, 2007 \\
\hline \multirow{2}{*}{ Glutamato } & 2,053 & Este trabalho \\
\hline & 1,650 & Swiech, 2007 \\
\hline \multirow{2}{*}{ Glutamina } & 1,936 & Este trabalho \\
\hline & 2,300 & Swiech, 2007 \\
\hline \multirow{2}{*}{ Histidina } & 0,410 & Este trabalho \\
\hline & 0,220 & Swiech, 2007 \\
\hline Isoleucina & 0,760 & Swiech, 2007 \\
\hline \multirow{2}{*}{ Leucina } & 0,420 & Este trabalho \\
\hline & 0,360 & Swiech, 2007 \\
\hline \multirow{2}{*}{ Lisina } & 0,876 & Este trabalho \\
\hline & 0,640 & Swiech, 2007 \\
\hline \multirow{2}{*}{ Metionina } & 1,162 & Este trabalho \\
\hline & 1,000 & Swiech, 2007 \\
\hline \multirow{2}{*}{ Prolina } & 0,767 & Este trabalho \\
\hline & 0,600 & Swiech, 2007 \\
\hline \multirow{2}{*}{ Serina } & 0,661 & Este trabalho \\
\hline & 0,310 & Swiech, 2007 \\
\hline \multirow{2}{*}{ Tirosina } & 0,301 & Este trabalho \\
\hline & 0,230 & Swiech, 2007 \\
\hline Treonina & 0,350 & Swiech, 2007 \\
\hline \multirow{2}{*}{ Valina } & 0,808 & Este trabalho \\
\hline & 0,620 & Swiech, 2007 \\
\hline
\end{tabular}




\subsection{PREPARO DO BANCO DE CÉLULAS PARA CULTIVOS EM BIORREATOR}

As linhagens foram cultivadas em meio SF 900 II SFM ${ }^{\circledR}$ (Invitrogen, EUA) em frascos tipo schott (volume total de $100 \mathrm{~mL}$ e com um volume útil de $20 \mathrm{~mL}$ ) com um inóculo inicial de $5 \times 10^{5} \mathrm{cel} / \mathrm{mL}$. Após a inoculação, os schotts foram colocados em um incubador rotativo (modelo Innova 4000, New Brunswick Scientific, EUA) a $100 \mathrm{rpm}$ e $28^{\circ} \mathrm{C}$, até que as células atingissem a sua fase exponencial (cerca de 3 dias). Esta fase é a mais indicada para o congelamento das células.

Às células centrifugadas foram adicionados 40\% (v/v) de meio SF 900 II fresco, $10 \%(\mathrm{v} / \mathrm{v})$ de dimetilsulfoxido (Sigma, EUA) e 50\% (v/v) de soro fetal bovino (Invitrogen, EUA). Em seguida, adicionou-se $1 \mathrm{~mL}$ de suspensão com aproximadamente $10^{7}$ células em cada criotubo. O congelamento foi feito em etapas, ou seja, primeiramente as células foram colocadas no freezer a uma temperatura de $-20^{\circ} \mathrm{C}$ por um período de 24 horas, depois foram armazenadas pelo mesmo período de 24 horas no freezer a uma temperatura de $-80^{\circ} \mathrm{C}$. Após este tempo em $-80^{\circ} \mathrm{C}$, as células foram transferidas para o nitrogênio líquido (cerca de $-200^{\circ} \mathrm{C}$ ).

\subsection{INÓCULO}

Os inóculos dos cultivos em biorreator foram preparados em frascos tipo schott de $100 \mathrm{~mL}$, com volume de trabalho de $20 \mathrm{~mL}$. Os schotts foram inoculados com $10^{6} \mathrm{cel} / \mathrm{mL}$ e mantidos durante dois dias a $28^{\circ} \mathrm{C}$ em um incubador rotativo (shaker) a 100 rpm, como mostrado na Figura 8.

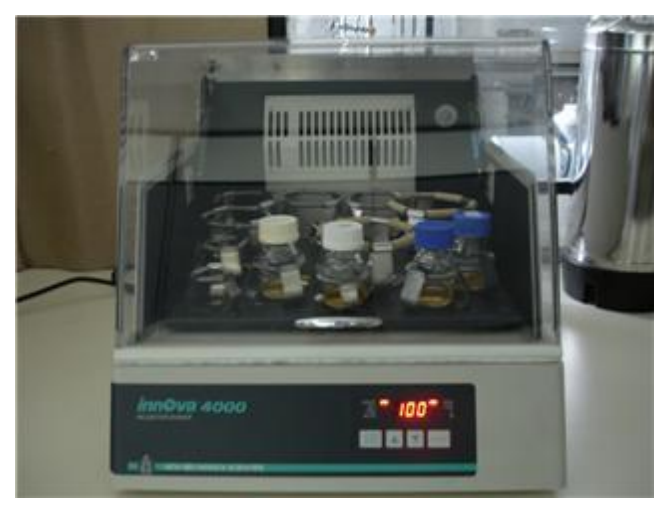

Figura 8: Shaker contendo células S2 no schotts com uma velocidade de agitação de 100rpm. 
Antes de inocular, foi necessário determinar a concentração celular de cada schott para adicionar a quantidade de células necessárias no biorreator. A concentração celular ideal para o inóculo do biorreator foi de $5 \times 10^{5} \mathrm{cel} / \mathrm{mL}$. A transferência foi realizada por um frasco schott conectado ao biorreator por uma mangueira de silicone.

\subsection{METODOLOGIA ANALÍTICA}

\subsubsection{Concentração Celular e Viabilidade}

O procedimento foi iniciado retirando-se uma amostra de meio de 90عL à qual se adicionavam $10 \mathrm{\varepsilon L}$ de azul de Tripan 0,4\% (Sigma, EUA). Na sequência procedia-se com a homogeneização da mistura; $10 \varepsilon \mathrm{L}$ eram depositados cuidadosamente, na câmara de Neubauer, entre a lamínula e o hemacitômetro (FRESHNEY, 1995). Quando a concentração celular atingia a concentração de $10^{7}$ células $/ \mathrm{mL}$, para facilitar a contagem, efetuava-se outra diluição da amostra. Assim, 10 عL da amostra eram diluídas em 80 عL de PBS $(0,13 \mathrm{M} \mathrm{NaCl}, 2 \mathrm{mM} \mathrm{KCl}, 8 \mathrm{mM}$ $\mathrm{Na}_{2} \mathrm{HPO}_{4}$ e $15 \mathrm{mM} \mathrm{KH}_{2} \mathrm{PO}_{4}$ ) e adicionava-se 10 \&L do corante. Ou seja, resultando em uma diluição total de 10 vezes.

Com a ajuda do microscópio, determinava-se o número de células e a sua viabilidade. As células mortas absorvem o corante por causa das falhas em sua membrana, tornando-se azuladas e diferenciando-se das células viáveis (BUTLER, 2004).

Em todas as amostras, as contagens foram feitas em duplicata, ou seja, a diluição da amostra com o azul de Tripan foi feita 2 vezes antes de colocar sobre a câmara. Foram contados para cada amostra diluída quatro quadrantes, resultando em um total de 16 quadrantes com aproximadamente 50 células por quadrante. Os desvios padrões foram calculados para cada amostra e estão representados nos gráficos de cada ensaio.

Além da determinação da concentração celular utilizando câmara de Neubauer, duas outras formas para determinar o mesmo parâmetro foram utilizadas: determinação através da massa seca de células e através da absorbância do meio. 
Para determinar a massa seca das células, $5 \mathrm{~mL}$ da amostra foram filtrados à vácuo em membrana de 0,45 $\mu \mathrm{m}$ (Milipore) previamente seca e pesada. A membrana permaneceu em estufa a $85^{\circ} \mathrm{C}$ overnight para a secagem completa e foi pesada novamente no dia seguinte. A diferença entre as massas corresponde ao peso em massa de células retidas na membrana. Em suma, a razão entre a massa encontrada e o volume de amostra filtrado resulta a concentração celular total em gramas de massa seca por litro (g massa seca/L).

A concentração celular total também foi estimada por leitura da absorbância a $600 \mathrm{~nm}\left(\mathrm{Abs}_{600}\right)$ em espectrofotômetro (Genesys 20, Thermo Scientific, EUA). As amostras com absorbância maior que 0,4 eram diluídas no próprio meio SF 900 II. Para determinar a concentração celular através da leitura de absorbância foi feita uma curva de correlação entre as duas grandezas.

\subsubsection{Glicose, Lactato, Glutamato e Glutamina}

As amostras retiradas do biorreator foram centrifugadas para a separação das células do sobrenadante. Para as análises, foram armazenados $2 \mathrm{~mL}$ do sobrenadante, $1 \mathrm{~mL}$ para a análise da glicose e lactato e $1 \mathrm{~mL}$ é armazenado para a análise da concentração de glutamina e glutamato e $1 \mathrm{~mL}$ para análise de amônio. Todas essas amostras são colocadas em eppendorf à $-20^{\circ} \mathrm{C}$.

As análises para a quantificação de glicose e lactato foram realizadas em HPLC Waters (EUA) com coluna SHODEX HPX87H em um detector com índice de refração Waters a $410 \mathrm{~nm}$ e $1 \mathrm{~mL} / \mathrm{min}$ de solução de ácido sulfúrico $5 \mathrm{mM}$ como fase móvel.

As análises de glutamato e de glutamina foram realizadas enzimaticamente pelo analisador bioquímico de duplo canal automático YSI 2700 Select (Yellow Spring Instruments, EUA).

\subsubsection{Amônio}

Para a dosagem de amônio, como dito no item 4.4.2, $1 \mathrm{~mL}$ do sobrenadante foi reservado e armazenado à $-20^{\circ} \mathrm{C}$. Análises para a quantificação de amônio só foi 
realizada nos ensaios contínuos. Infelizmente, as amostras dos ensaios anteriores (batelada) foram perdidas devido a um problema no freezer, não detectado a tempo de recuperar as amostras.

A determinação da concentração do amônio foi feita utilizando-se um potenciômetro (Mettler, modelo 225, Brasil) e um eletrodo específico (Orion, modelo 9512, EUA). Este conjunto detecta, com a adição de $\mathrm{NaOH}$ (Merck, Brasil), variações de milivoltagem quando o amônio é convertido em amônia. A solução de $\mathrm{NaOH} 10 \mathrm{M}$ é adicionada às amostras na proporção de 1:100. Estas análises foram realizadas no IPT (Instituto de Pesquisas Tecnológicas).

As curvas de calibração foram feitas com soluções padrões de sulfato de amônio (Merck, Brasil) com concentrações na faixa de 0,1 a $1 \mathrm{~g} / \mathrm{L}$. Amostras de referência foram produzidas no laboratório e são utilizadas na validação da curva de calibração.

\subsubsection{Aminoácidos}

As análises para a quantificação de aminoácidos das amostras foram realizadas pelo Laboratório de Química de Peptídeos do Instituto de Química da Universidade de São Paulo.

Foram determinadas as concentrações molares dos aminoácidos em um analisador automático (Dionex, EUA), composto de um amostrador automático (AS40), uma bomba quaternária (GS50), um forno de coluna (LC25), uma coluna de troca iônica (AminoPac PA10), um detector eletroquímico (ED50) e uma plataforma ñChromeleonòpara controle e aquisição de dados. Neste analisador, os aminoácidos foram separados em uma coluna de troca iônica e detectados diretamente (ausência de derivatização) por amperometria. A quantidade de cada aminoácido foi calculada baseando-se em 3 análises de uma solução padrão contendo $10 \mu \mathrm{M}$ de cada aminoácido. 


\subsubsection{Glicoproteína do Vírus da Raiva (GPV)}

Nas amostras retiradas do biorreator, uma quantidade de amostra contendo $10^{6}$ células (concentração de células totais) é colocada em um eppendorf para centrifugação. Após esta etapa, o sobrenadante é descartado e é adicionado ao pellet $0,5 \mathrm{~mL}$ de solução $\mathrm{T} 4$. Em seguida a amostra foi armazenada a $-20^{\circ} \mathrm{C}$. A solução T4 é uma solução tampão composta por $25 \mathrm{mM}$ de TRIS (Merck, EUA), $25 \mathrm{mM} \mathrm{NaCl}, 5 \mathrm{mM} \mathrm{MgCl}$, $1 \mathrm{mM}$ PMSF, um inibidor de protease (PMSF) (Fluka, EUA) e $20 \%$ Glicerol em pH igual a 7,4 .

Vale ressaltar que a GPV é uma proteína expressa na membrana celular, com isso a análise de ELISA (Enzyme-Linked Immunosorbent Assay) é realizada com amostras de células lisadas utilizando detergente Nonidet (2x) (Roche Diagnostics, Suíça) e vórtex de 10 segundos a cada 15 minutos por um período de 1 hora, sendo as amostras mantidas em geladeira ou banho de gelo. Em seguida, as amostras são centrifugadas a $10.625 \mathrm{~g}$ por 10 minutos para retirada dos debris celulares e apenas o sobrenadante obtido após a centrifugação é analisado, gerando resultados expressos na forma de concentração de GPV ( $\mu \mathrm{g} / \mathrm{L}$ ) e teor de proteína $\left(\mu \mathrm{g} / 10^{7} \mathrm{cel}\right)$.

A concentração de GPV foi analisada por ELISA, utilizando o kit ñRabies Glycoprotein Enzyme Immunoassayò (Instituto Pasteur, França). O anticorpo de cobertura utilizado foi a Imunoglobulina ( $\lg G$ ) contra a glicoproteína da raiva, marcado com peroxidase e utilizado para detectar o antígeno GPV (SWIECH, 2007).

\subsection{BIORREATOR}

Foi utilizado biorreator da marca B. Braun (Alemanha), modelo Biostat B, com dorna de $2 \mathrm{~L}$, equipado com controladores de frequência de agitação, $\mathrm{pH}$, temperatura e oxigênio dissolvido (a transferência de oxigênio foi realizada por borbulhamento de $\operatorname{Ar}$ ou $\mathrm{O}_{2}$ e $\mathrm{N}_{2}$ ). Tais controladores estão em comunicação com um microcomputador (através de um sistema da aquisição de dados Compact Field Point), o qual é dotado de software desenvolvido em linguagem LabVIEW (National 
Instruments, EUA) capaz de arquivar e apresentar graficamente os dados de processo.

O impelidor utilizado foi o do tipo Rushton e o aspersor de ar utilizado foi do tipo anel de inox e está localizado na base do reator.

No decorrer deste projeto, o biorreator foi operado em experimentos em regime descontínuo e em contínuo. Ambos os tipos de cultivos compreendem as seguintes etapas: calibração do eletrodo de $\mathrm{pH}$; esterilização do reator vazio; carregamento do reator com o meio estéril; estabilização da temperatura de cultivo; calibração do eletrodo de oxigênio dissolvido; inoculação e cultivo com amostragens periódicas (uma ou duas vezes ao dia).

A etapa de preparo do biorreator antes da esterilização é um processo importante, pois o reator deverá ir para a autoclave da mesma forma como ele deverá ser operado posteriormente. Ou seja, deverá ser autoclavado com os eletrodos e com todas as conexões necessárias, assim diminuem as chances de uma posterior contaminação por microorganismos.

Após a esterilização do mesmo, é feito o carregamento com o meio fresco e espera-se um tempo de 5 horas para a polarização do eletrólito do eletrodo de oxigênio. Só assim o eletrodo estará estável e poderá ser calibrado. Com o eletrodo calibrado, o controle de oxigênio dissolvido era acionado e o reator inoculado.

Para a realização do processo contínuo foi necessária a montagem de um sistema para atender as exigências deste processo. Este sistema inclui um frasco para a alimentação de meio fresco, cujo fluxo foi controlado por uma bomba peristáltica da marca Watson Marlow (modelo 101U, EUA), o biorreator B. Braun e um frasco para coleta do caldo fermentado por intermédio de um tubo posicionado de forma a manter um volume constante no fermentador. Este dispositivo faz com que o excesso de volume do líquido e de espuma (formada ao longo de cultivo) sejam retirados do sistema por uma bomba peristáltica (própria do Biostat B) para um frasco de saída. Após alguns problemas de rompimento na mangueira de saída, a mangueira mais adequada / resistente utilizada foi a 06404-14 Norprene (Masterflex, EUA).

Para uma constante verificação da vazão de alimentação foi adicionada ao sistema uma balança sob este frasco. Foi instalado ainda um fluxômetro para 
controlar a vazão total da mistura de gases no reator em $120 \mathrm{~mL} / \mathrm{min}$. Além disso, um manômetro media constantemente a pressão dentro do reator. A Figura 9 abaixo é uma foto que mostra todo o esquema montado.

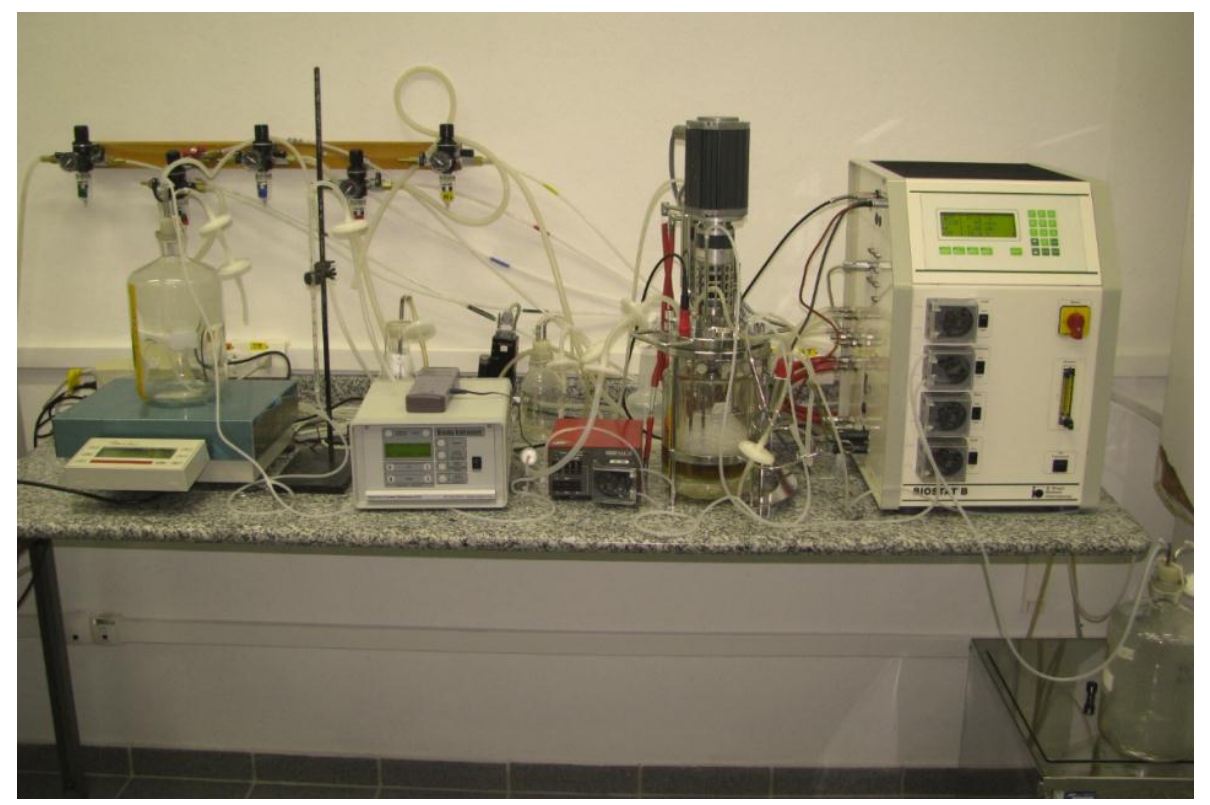

Figura 9: Foto do biorreator e seus acessórios para o funcionamento do processo contínuo.

A Figura 10 representa um fluxograma para ilustrar melhor as entradas e saídas do processo.

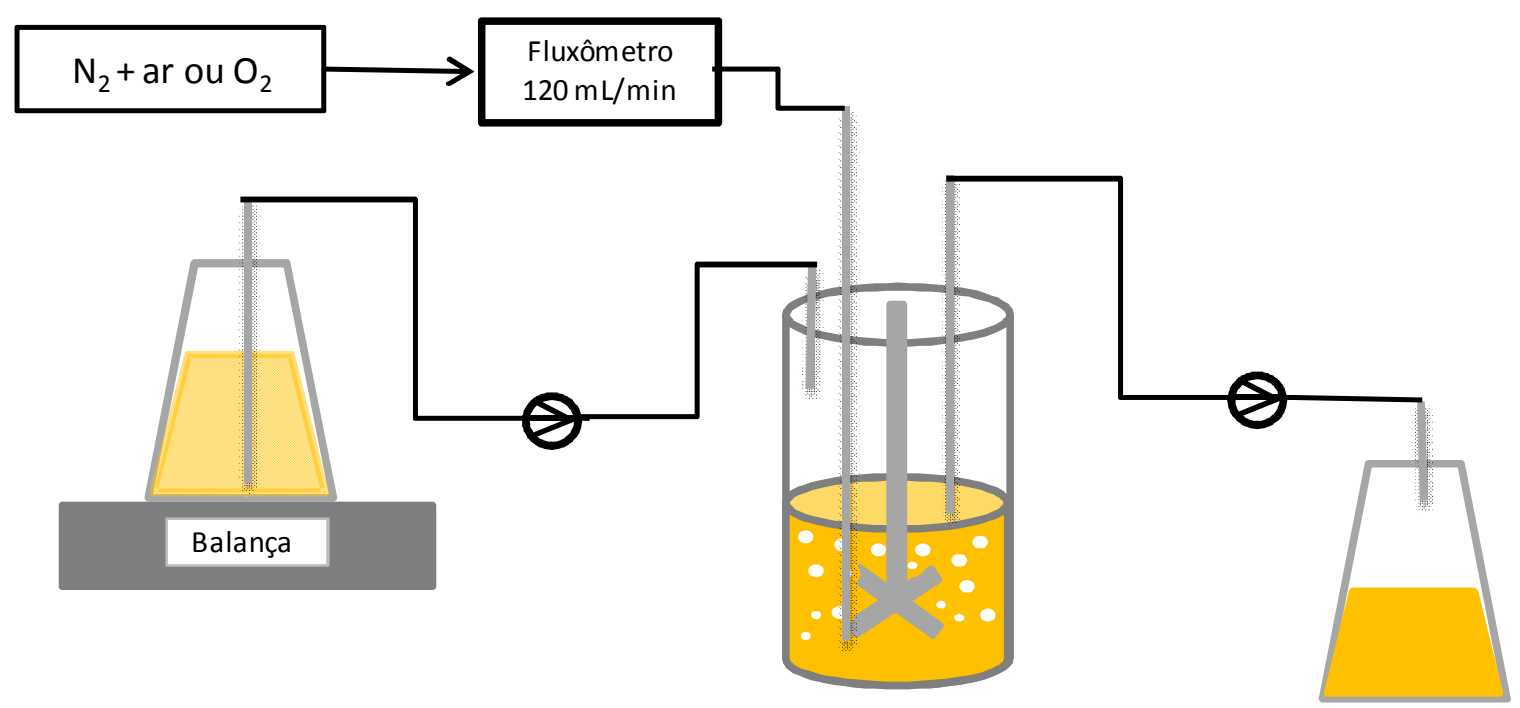

Figura 10: Fluxograma representando as entradas e saídas do processo contínuo. 


\subsubsection{Ensaios em Biorreator em Regime Descontínuo}

Foram realizados dois ensaios em batelada com as células S2. Ambos possuem parâmetros semelhantes, porém o tipo de linhagem utilizado é diferente. Os ensaios foram denominados como Batelada 1 e Batelada 2 e as condições de cultivo para estes experimentos são mostrados na tabela 4.

Tabela 4: Condições de cultivo dos ensaios em Batelada.

\begin{tabular}{ccc}
\hline Condições de Cultivo & Batelada 1 & Batelada 2 \\
\hline \hline Linhagem celular & S2MtGPV & S2AcGPV \\
\hline Meio de cultivo & SF 900 II & SF 900 II \\
\hline OD $(\%)$ & 30 & 30 \\
\hline Agitação $(\mathrm{rpm})$ & 90 & 90 \\
\hline Temperatura $\left({ }^{\circ} \mathrm{C}\right)$ & 28 & 28 \\
\hline $\mathrm{pH}$ & não controlado & não controlado \\
\hline Vazão entrada de gases $(\mathrm{mL} / \mathrm{min})$ & 120 & 120 \\
\hline Volume útil do reator $(\mathrm{mL})$ & 1000 & 1000 \\
\hline Inóculo $\left(\times 10^{6}\right.$ cel $\left./ \mathrm{mL}\right)$ & 0,582 & 0,305 \\
\hline
\end{tabular}

O principal objetivo destes ensaios, além de avaliar a melhor opção de célula, foi calcular parâmetros cinéticos para a realização de um posterior cultivo contínuo.

\subsubsection{Ensaios em Biorreator em Regime Contínuo}

Foram realizados três ensaios em processo contínuo com as células S2AcGPV. Todos os experimentos foram realizados sob as mesmas condições de cultivo, como mostrado na tabela 5. 
Tabela 5: Condições de cultivo dos ensaios contínuos

\begin{tabular}{cc}
\hline Condições de Cultivo & Contínuo 1 \\
\hline \hline Linhagem celular & S2AcGPV \\
\hline Meio de cultivo & SF 900 II \\
\hline OD $(\%)$ & 30 \\
\hline Agitação $(\mathrm{rpm})$ & 90 \\
\hline Temperatura $\left({ }^{\circ} \mathrm{C}\right)$ & 28 \\
\hline $\mathrm{pH}$ & não controlado \\
\hline Vazão entrada de gases $(\mathrm{mL} / \mathrm{min})$ & 120 \\
\hline Volume útil do reator $(\mathrm{mL})$ & 500 \\
\hline Inóculo $\left(\times 10^{6}\right.$ cel $\left./ \mathrm{mL}\right)$ & 0,408 \\
\hline
\end{tabular}

O principal objetivo do primeiro experimento em regime contínuo foi testar três diferentes vazões específicas de alimentação, para um melhor entendimento da fisiologia da célula. As diferentes vazões específicas de alimentação testadas permitiram obter velocidades específicas de crescimento iguais a 0,8,0,5, 0,2 dia ${ }^{-1}$ uma vez atingido o estado estacionário $\left(\mu_{\mathrm{x}}=\mathrm{D}\right)$.

Nos dois experimentos seguintes foram utilizadas as mesmas condições de cultivos do primeiro ensaio, porém, foi imposta apenas uma única taxa de diluição. Quando o processo alcança o estado estacionário a composição do meio de alimentação é alterada. O principal objetivo destes ensaios foi analisar o comportamento do metabolismo celular após a adição de aminoácidos.

No ensaio denominado Contínuo 3, foi adicionado ao meio $1,9 \mathrm{~g} / \mathrm{L}$ de glutamina, ou seja, o dobro da concentração encontrada no meio SF 900 II. No Contínuo 5 dobrou-se a concentração de quatro aminoácidos: prolina, serina, asparagina e cisteína.

\subsection{EXPERIMENTOS EM SCHOTT}

\subsubsection{Testes com diferentes concentrações de Sulfato de Cobre}

Para determinação do efeito tóxico do indutor nas células S2MtGPV foram realizados quatro diferentes tipos de testes em schott com o sulfato de cobre 
$\left(\mathrm{CuSO}_{4}\right)$, todos em duplicata. Todos os schotts foram inoculados com $5 \times 10^{5} \mathrm{cel} / \mathrm{mL}$ em $20 \mathrm{~mL}$ de volume útil. $A$ indução com o sulfato de cobre foi realizada quando a concentração celular atingiu 2 a $6 \times 10^{6} \mathrm{cel} / \mathrm{mL}$ (cerca de 2 dias). A concentração do metal para a primeira indução em todos os schotts foi igual a $700 \mu \mathrm{M}$, que é considerada uma concentração ideal (SANTOS et al, 2007).

A partir desta etapa, todos os schotts foram repicados de 2 em 2 dias, no qual retirava-se $10 \mathrm{~mL}(50 \%)$ de meio fermentado e adicionava-se $10 \mathrm{~mL}$ de meio fresco em cada schott. A diferença entre cada schott (A, B, C e D) se inicia após o primeiro repique, no qual passa-se a variar a concentração de sulfato para análise de comportamento do metabolismo celular.

No schott denominado $A$, após o primeiro repique, foi mantida a concentração de sulfato de cobre ao longo dos repiques, ou seja, constante em $700 \mu \mathrm{M}$.

No schott B, após a primeira troca, não foi adicionado sulfato de cobre. Portanto a concentração final nesta etapa foi de $350 \mu \mathrm{M}$. A partir desse ponto, nos sucessivos repiques, foi feita uma correção com o indutor para manter a concentração final de cobre igual a $300 \mu \mathrm{M}$.

No teste $\mathrm{C}$ elevou-se gradualmente a concentração do metal. Ou seja, a cada repique uma quantidade de sulfato de cobre foi adicionada ao cultivo, iniciando com $700 \mu \mathrm{M}$ e alcançando $1200 \mu \mathrm{M}$.

No último schott, o teste $D$, não foi adicionado indutor após o primeiro repique. Assim, ao longo dos sucessivos repiques, a concentração de sulfato de cobre foi diminuindo gradativamente por simples diluição com meio fresco. A Figura 11 representa um esquema mostrando cada um dos testes realizados. 


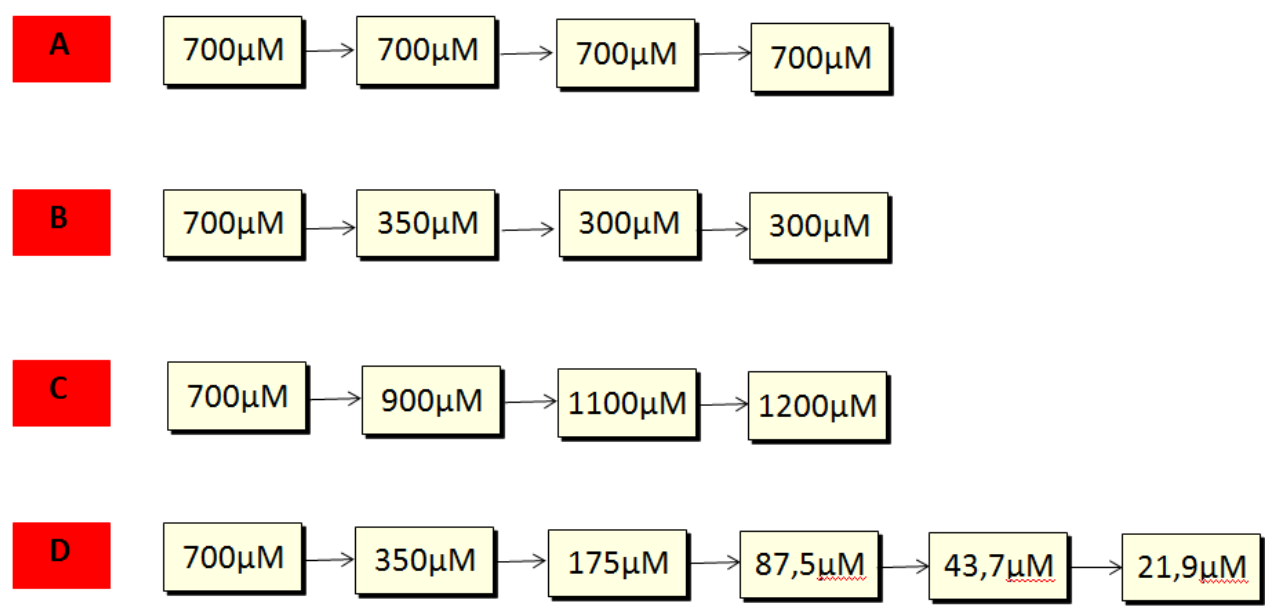

Figura 11: Esquema ilustrando os testes realizados em schott com $\mathrm{CuSO}_{4}$.

\subsubsection{Testes com diferentes concentrações de Glutamina}

Como visto anteriormente, alguns trabalhos indicam que a glutamina pode ser o substrato que limita o crescimento celular nos cultivos com células S2 em batelada. Com base nisso, foram realizados ensaios em schott, em batelada, com diferentes concentrações iniciais de glutamina no meio de cultura. Os schotts foram inoculados com $5 \times 10^{5} \mathrm{cel} / \mathrm{mL}$ em $20 \mathrm{~mL}$ de volume útil.

Foram testados quatro diferentes concentrações de glutamina no meio de cultura. A concentração deste aminoácido no meio SF 900 II é de, aproximadamente, $1,80 \mathrm{~g} / \mathrm{L}$. Para a realização destes ensaios adicionou-se glutamina ao meio SF 900 II, obtendo-se concentrações finais iguais a 2,55, 3,40 e $4,80 \mathrm{~g} / \mathrm{L}$. Todos os ensaios foram realizados em duplicata.

\subsubsection{Testes com diferentes concentrações de Aminoácidos}

Com o intuito de descobrir se há limitação por alguns aminoácidos no cultivo das células S2 no meio SF 900 II, foram realizados testes em schott com diferentes concentrações de aminoácidos. Todos os ensaios foram realizados em duplicata.

Os aminoácidos testados foram: Asparagina (Asn), Prolina (Pro), Serina (Ser) e Cisteína (Cis). Foram realizados seis testes diferentes, um deles com o SF 900 II sem adição de aminoácidos, denominado rennsaio controleò Em apenas um 
dos shotts (4 aa) foram adicionados todos os quatro aminoácidos $(1,05 \mathrm{~g} / \mathrm{L}$ de Asn; 0,77 g/L de Pro; $0,65 \mathrm{~g} / \mathrm{L}$ de Ser; 0,13 g/L de Cis), ou seja, atingindo o dobro da concentração existente no meio de cultura. Por fim, nos demais quatro schotts denominados de Asn, Pro, Ser e Cis - foram adicionados em cada um deles: 1,05 g/L de Asn; 0,55 g/L de Pro; 0,65 g/L de Ser; 0,13 g/L de Cis, respectivamente.

\subsection{TRATAMENTO DOS DADOS EXPERIMENTAIS}

Os dados das variáveis em função do tempo foram alisados através de um programa desenvolvido em Matlab chamado TrataDados (PAMBOUKIAN et al., 2009).

\subsubsection{Determinação das velocidades específicas}

A velocidade específica de crescimento é definida pela equação:

$$
\mu_{X}=\frac{1}{X v} \cdot \frac{d X}{d t}
$$

Onde, $X_{V}=$ concentração de células viáveis;

$\mathrm{t}=$ tempo de cultivo em dias;

$\mu_{X}=$ Velocidade específica de crescimento

A construção de um gráfico de $\ln X_{V}=f(t)$ permite uma visualização mais precisa das fases de crescimento celular nos ensaios ou nas fases em batelada. No trecho retilíneo a derivada é constante e máxima em relação aos outros pontos.

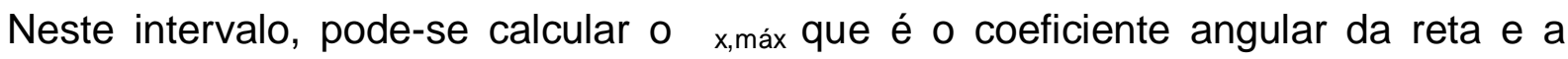
diferença $t_{i} i ̈$ t indica a fase exponencial de crescimento, como mostra a Equação 2.

$$
\ln \frac{X v}{X v_{i}}=\mu_{\text {máx }} .\left(t_{i}-t\right)
$$

Onde $\mathrm{X}_{\mathrm{Vi}}$ representa a concentração de células viáveis no início da fase exponencial e $t_{i} 0$ início desta fase de crescimento. $O$ tratamento dos dados é feito somente para o ajuste da curva de $\mu_{x, \text { máx. }}$ 
4.7.2 Produtividade máxima em GPV (' GPV)

A produtividade em GPV dos ensaios em batelada foi calculada através da seguinte equação:

$$
\Pi=
$$

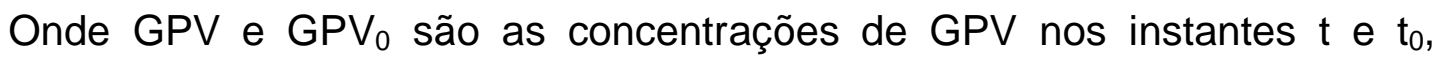
respectivamente. Nos ensaios e nas fases em batelada $0 t_{0}$ representado pelo primeiro instante em que houve dosagem de GPV. A partir destes valores, traçou-se o gráfico $\Pi_{\mathrm{GPV}}=\mathrm{f}(\mathrm{t})$ e identificou-se o instante no qual o valor de $\Pi$ GPV era máximo (AUGUSTO et al., 2010).

Para os ensaios contínuos, a produtividade foi calculada através da Equação 4. No qual, GPV é a concentração da glicoproteína em $\mu \mathrm{g} / \mathrm{L}$ e $\mathrm{D}$ é a vazão específica de alimentação em horas.

$$
\Pi=\text {. }
$$

\subsubsection{Cálculo dos Fatores de Conversão}

Nos ensaios ou nas fases descontínuas, considerando um determinado tempo t de cultivo, os valores das concentrações de células e metabólitos podem ser relacionados entre si, através dos fatores de conversão definidos por:

- Conversão de glicose a célula

$$
/ \quad=
$$

Onde $X$ e $X_{0}$ são as concentrações de células viáveis no instante $t$ e $t_{0}$, respectivamente, e GLC e $\mathrm{GLC}_{0}$ são as concentrações de glicose nesses mesmos instantes.

- Conversão de glutamina a célula

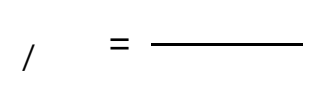


Onde $X$ e $X_{0}$ são as concentrações de células viáveis no instante $t$ e $t_{0}$, respectivamente, e GLN e $\mathrm{GLN}_{0}$ são as concentrações de glutamina nesses mesmos instantes.

- Conversão de glutamina a amônia

$$
/ \quad=
$$

Onde GLN e GLN $\mathrm{G}_{0}$ são as concentrações de glutamina nos instantes t e $\mathrm{t}_{0}$, respectivamente, e $\mathrm{NH}_{4}$ e $\mathrm{NH}_{4,0}$ são as concentrações de amônia nesses mesmos instantes.

- Conversão de glutamina a alanina

$$
/ \quad=
$$

Onde ALA e $\operatorname{ALA}_{0}$ são as concentrações de alanina nos instantes t e $t_{0}$, respectivamente, e GLN e $\mathrm{GLN}_{0}$ são as concentrações de glutamina nesses mesmos instantes.

- Conversão de cisteína a célula

$$
1=
$$

Onde $\mathrm{X}$ e $\mathrm{X}_{0}$ são as concentrações de células viáveis no instante $\mathrm{t}_{\mathrm{e}} \mathrm{t}_{0}$, respectivamente, e Cis e $\mathrm{Cis}_{0}$ são as concentrações de cisteína nestes mesmos instantes.

Neste trabalho, para os ensaios em batelada, os fatores de conversão foram calculados na fase exponencial dos cultivos através do coeficiente angular da reta do gráfico. Os fatores de conversão calculados foram: $Y_{X / G L C}{ }^{\text {EXP }}$ e $Y_{X / G L N}{ }^{E X P}$.

Para os ensaios contínuos utiliza-se fórmula semelhante, porém as concentrações no instante $t_{0}$ são substituídas pelas concentrações no meio de alimentação e no instante t pelas concentrações presentes no reator no estado estacionário. Os fatores de conversão calculados nos ensaios contínuos foram: $Y_{X / G L C}, Y_{X / G L N}, Y_{N H 4 / G L N}, Y_{A L A / G L N}, Y_{X / C I S}$ 


\subsubsection{Equacionamento do Biorreator para o Processo Contínuo}

Para um biorreator em processo contínuo sem reciclo de células, tem-se que:

- Balanço material para as células:

$$
\frac{d(X . V)}{d t}=\left(X_{f}-X\right) \cdot F+\mu . X . V
$$

Como o volume do reator é constante e dividindo a equação por $\mathrm{V}$, temos:

$$
\frac{d(X)}{d t}=\left(X_{f}-X\right) \cdot \frac{F}{V}+\mu \cdot X
$$

Sabe-se que quando o sistema atinge o estado estacionário, $X$ é constante e, com isso, $\mathrm{dX} / \mathrm{dt}$ é igual a zero. Logo:

$$
\left(X-X_{f}\right) \cdot \frac{F}{V}=\mu \cdot X
$$

Considerando $\mathrm{X}_{\mathrm{f}}=0$ (alimentação com meio estéril), obtém-se:

$$
\mu=\frac{F}{V}=D
$$

Quando a vazão específica de alimentação é maior que a velocidade específica máxima de crescimento celular ocorre uma lavagem no reator, ou seja, a concentração celular cai.

- Balanço material para o substrato (S), sabendo que $S_{f}$ é a concentração do substrato no meio de alimentação:

$$
\frac{d(S . V)}{d t}=\left(S_{f}-S\right) . F-\mu \cdot X \cdot \frac{V}{Y_{x / s}}
$$

No estado estacionário, tem-se que $\mathrm{dS} / \mathrm{dt}=0$ e que $\mu=\mathrm{D}$, portanto:

$$
Y_{x / s}=\frac{X}{S_{f}-S}(c e ́ l / g)
$$

- Balanço material para o produto GPV:

$$
\frac{d(G P V \cdot V)}{d t}=\left(G P V_{f}-G P V\right) \cdot F+\mu_{P} . X . V
$$


Dividindo por $\mathrm{V}$ e considerando $\mathrm{GPV}_{\mathrm{f}}=0$ (concentração de produto no meio de alimentação), tem-se:

$$
G P V=\mu_{P} \cdot \frac{X}{D}
$$

A concentração de GPV ( $\mu \mathrm{g} / \mathrm{L})$ é calculada pela multiplicação do teor de GPV pela concentração de células totais.

O critério adotado para determinar o estado estacionário foi avaliar variáveis tais como a concentração de glicose, de glutamina e a concentração de células viáveis decorridos dois tempos de residência (razão entre o volume útil do reator e a vazão de alimentação). Para isso foi calculado o coeficiente de variação (cv) das amostras.

$$
c v=\frac{100 . \text { desvio } \_ \text {padrão }}{\text { Média }}
$$

Onde: $\quad$ desvio $_{-}$padrão $=s=\sqrt{\frac{\sum\left(y-y_{m}\right)^{2}}{N-1}}$

$$
\text { e a } \quad \text { média }=y_{m}=\frac{\sum y}{N}
$$

sendo y a grandeza em estudo, $y_{m}$ o valor da média calculada e $\mathrm{N}$ o número de amostras.

Justifica-se o uso do coeficiente de variação, pois ele permite que se expresse a variabilidade dos dados, sem que haja influência da ordem de grandeza das variáveis, o que facilita a comparação entre elas (TRIOLA, 2005). Para este projeto foi adotado que o estado estacionário foi atingido quando o cv possuía um valor menor ou igual a $10 \%$ para as variáveis como concentração celular, concentração residual de glicose e glutamina.

\subsection{ANÁLISE ESTATÍSTICA DOS EXPERIMENTOS REALIZADOS EM SCHOTT}

Todos os conjuntos de experimentos realizados em schott tiveram fins comparativos. Uma vez que foram realizados em duplicata, os dados experimentais 
obtidos foram dispostos em gráficos em função do tempo tomando o cuidado de se remover os pontos discrepantes. Os dados das duas repetições foram dispostos em apenas um gráfico. Com isso, foi possível calcular os parâmetros fisiológicos (velocidade específica máxima de crescimento e fatores de conversão) através de Regressão Linear obtida com auxílio do software GraphPad Prism 5 (GraphPad Software, EUA).

Porém, para a análise estatística das variáveis concentração celular máxima, concentração máxima de GPV e produtividade máxima, foi aplicado um teste de hipóteses sobre as médias através de Análise de Variância (ANOVA).

O nível de significância (Ǔ) adotado para este trabalho foi de 5\%, ou seja, a probabilidade de cometer um erro do tipo 1 , no qual se caracteriza por rejeitar uma hipótese quando, de fato, ela é verdadeira.e não deveria ser rejeitada (LEVINE e BERENSON, 2005). Também para operacionalização da ANOVA fez-se uso do programa GraphPad Prism 5 (GraphPad Software, EUA).

Esse software, como outros de estatística, apresentam como resultados o método do $p$-valor para estes testes de hipóteses. O p-valor é conhecido como nível observado de significância, que representa o menor nível a partir do qual a hipótese nula pode ser rejeitada para um determinado conjunto de dados (LEVINE e BERENSON, 2005). A regra de decisão para rejeitar a hipótese nula no método $p$ valor é:

- Se o p-valor for maior ou igual a Ŭ, a hipótese nula não é rejeitada.

- Se o p-valor for menor que Ŭ, a hipótese nula é rejeitada. 


\section{RESULTADOS E DISCUSSÃO}

\subsection{ENSAIOS EM BATELADA COM CÉLULAS S2}

Para a obtenção de dados preliminares e estabelecimento da linhagem celular para o desenvolvimento do processo contínuo, foram realizados dois experimentos em batelada com as linhagens S2 constitutiva e a indutível.

\subsubsection{Batelada 1}

O ensaio denominado Batelada 1 foi realizado com a linhagem celular indutível S2MtGPV. Visando condições que favorecessem o crescimento celular, a concentração de oxigênio dissolvido foi controlado em $30 \%$ da saturação, com a velocidade de agitação mantida em $90 \mathrm{rpm}$ e a temperatura controlada em $28^{\circ} \mathrm{C}$. A aeração foi realizada por borbulhamento de ar e $\mathrm{N}_{2}$ até o terceiro dia. A partir de então, dada a maior demanda de oxigênio decorrente do crescimento celular, a aeração passou a contar com fluxos de $\mathrm{O}_{2}$ e $\mathrm{N}_{2}$, visto que a primeira combinação de gases $\left(a r+N_{2}\right)$ já não era suficiente para manter a concentração de oxigênio dissolvido (OD) no set point desejado.

A concentração celular inicial foi de $5,8 \times 10^{5} \mathrm{cel} / \mathrm{mL}$. O pH foi monitorado, mas não controlado. No Gráfico 1 pode ser observado que o valor do $\mathrm{pH}$ permaneceu entre 6 e 7 .

Com relação à concentração de oxigênio dissolvido, ainda no Gráfico 1, nota-se que houve uma oscilação próxima ao valor do set point. Duas possibilidades explicam tal variação. A primeira seria o controlador PID de oxigênio dissolvido não estar devidamente sintonizado. A segunda estaria relacionada ao fato de o Biostat $B$ possuir apenas duas entradas de gases $\left(\right.$ ar e $\mathrm{O}_{2}$ ) enquanto que o cultivo com células animais, em seu início, necessita de $\mathrm{N}_{2}$ para o controle do oxigênio dissolvido. A maior oscilação ocorreu entre os dias 3,5 e 5, exatamente no período decorrente de adaptação da troca de gases ar e $\mathrm{N}_{2}$ no início para ar e $\mathrm{O}_{2}$ na fase seguinte. 
De forma a facilitar a compreensão, a curva de concentração celular com o tempo foi inserida em praticamente todos os gráficos. As linhas horizontais tracejadas desenhadas em alguns gráficos indicam o período da fase exponencial de crescimento.

O Gráfico 1 mostra as principais variáveis de processo que foram medidas constantemente durante o cultivo. Os dados de temperatura e de frequência agitação não são mostrados no gráfico, pois se mantiveram constantes ao longo do ensaio.

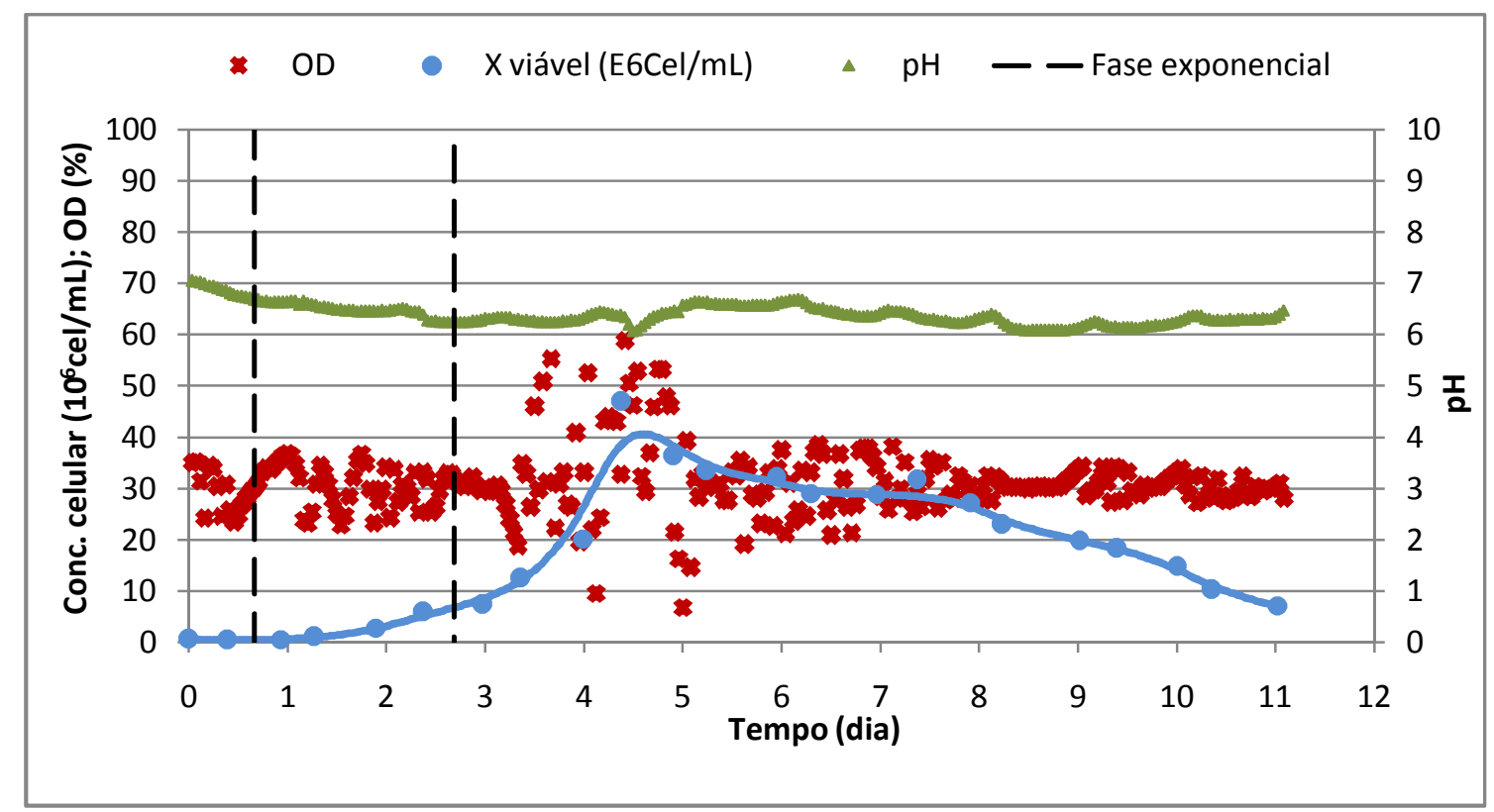

Gráfico 1: OD, pH e a Concentração de células viáveis da Batelada 1 ao longo do tempo.

A indução com 700 عM de sulfato de cobre para a síntese de GPV foi realizada em 2,4 dias de cultivo, quando as células atingiram uma concentração de $5,9 \times 10^{6} \mathrm{cel} / \mathrm{mL}$. O cultivo durou aproximadamente 11 dias. A concentração máxima de células viáveis observada foi de $40 \times 10^{6} \mathrm{cel} / \mathrm{mL}$. O Gráfico 2 mostra a concentração e a viabilidade celular ao longo do tempo.

Pode-se observar também que a concentração celular total (juntamente com a concentração de células viáveis) diminui de forma acelerada após o oitavo dia de cultivo. Isso decorre do fato da membrana celular se desfazer rapidamente logo após a morte da célula, diferentemente das células de mamífero que permanecem com a mesma forma após sua morte. 
Sendo assim, para as células S2 o método utilizado com azul de Tripan não é muito eficiente com relação à viabilidade, uma vez que colore as células mortas que estão somente com a membrana rompida. Isso faz com que a viabilidade ao logo do cultivo seja alta, uma vez que não seja possível contabilizar a concentração de células mortas. Com relação às células de mamíferos tal fato não é observado, pois a maior parte das células mortas permanece da mesma forma, ou seja, somente com a membrana rompida. A concentração de células totais em um ensaio com células de mamíferos permanece constante após a queda da viabilidade, uma vez que a concentração de células mortas só vai aumentando e não desaparecendo como nas células S2.

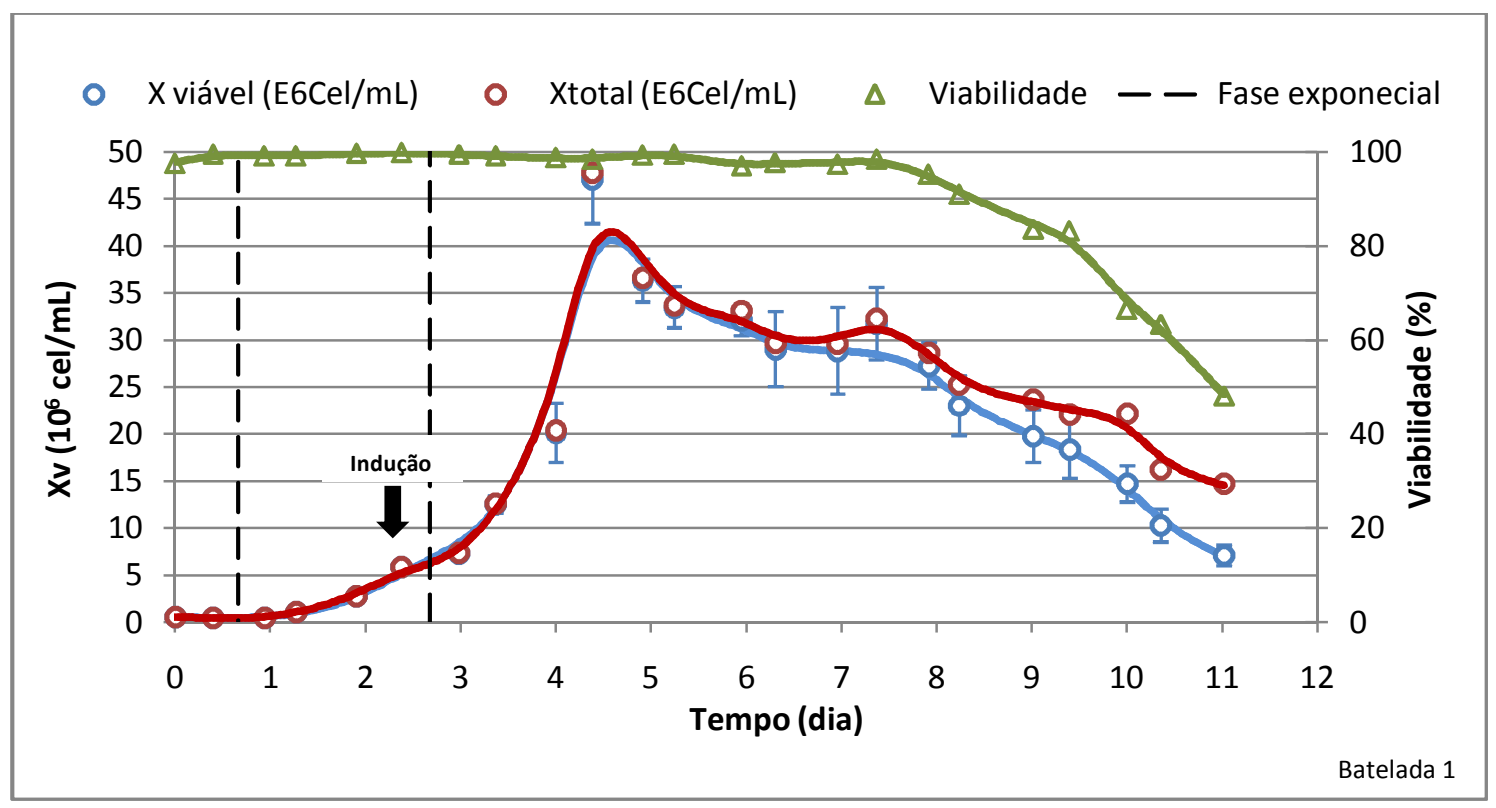

Gráfico 2: Crescimento Celular das Células S2MtGPV.

Conforme mostrado no Gráfico 3a, a velocidade específica de crescimento máxima $\left(\varepsilon_{\text {máx }}\right)$ calculada para este ensaio foi de $1,7 \mathrm{dia}^{-1}$. Este valor de $\varepsilon_{\text {máx é }}$ considerado alto quando comparado ao valor de $1,1 \mathrm{dia}^{-1}$ calculado por Ventini et al. (2010) nas seguintes condições de cultivo 28ํㅡ, 50\% OD, 90 rpm, aeração por borbulhamento de ar. Pode-se notar ainda no Gráfico 3a que a velocidade específica de crescimento diminui após a indução com o sulfato de cobre (indicada no gráfico pela seta). Os valores de $\mu_{x}$ foram calculados por $\mathrm{X} / \not$.

Com o programa TrataDados foi possível fazer o gráfico com o perfil da velocidade específica de crescimento ao longo do tempo, mostrado no Gráfico 3b. 

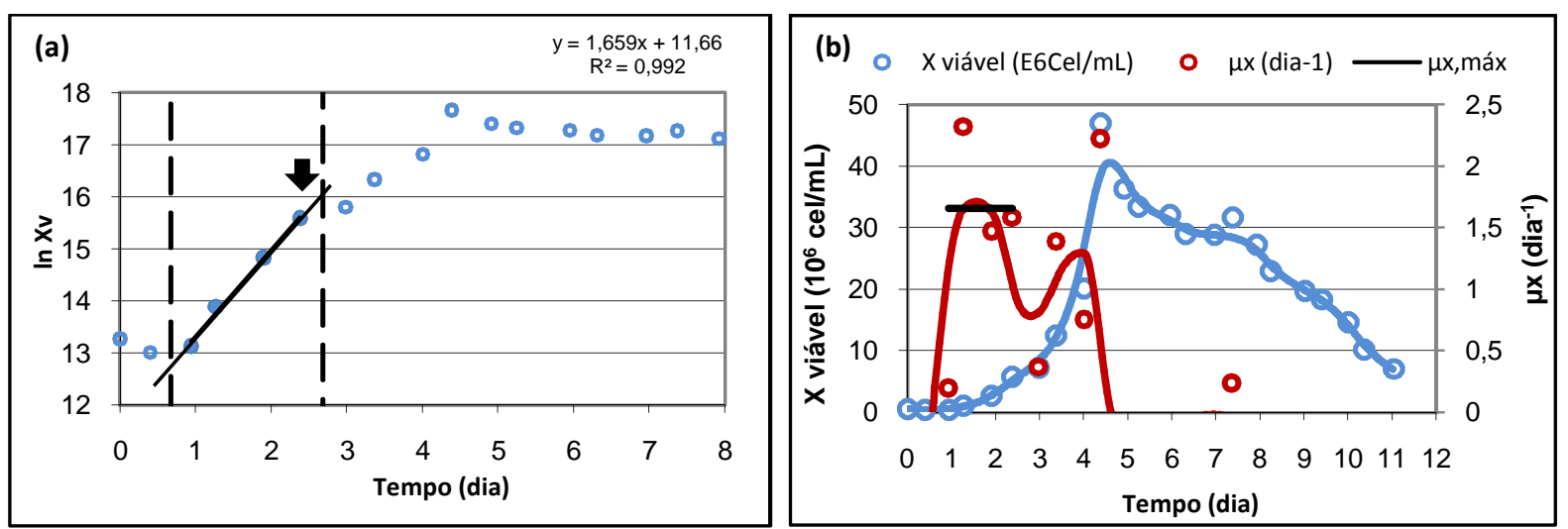

Gráfico 3: (a) Determinação de $\varepsilon_{x, \text { máx }}$ da Batelada 1 e (b) Curva de $\mu_{x}$ ao longo do cultivo.

No Gráfico 4, pode ser observado o perfil das concentrações de glicose e lactato ao longo do tempo. A glicose foi consumida, assim chegando ao final do ensaio com uma concentração de $0,13 \mathrm{~g} / \mathrm{L}$.

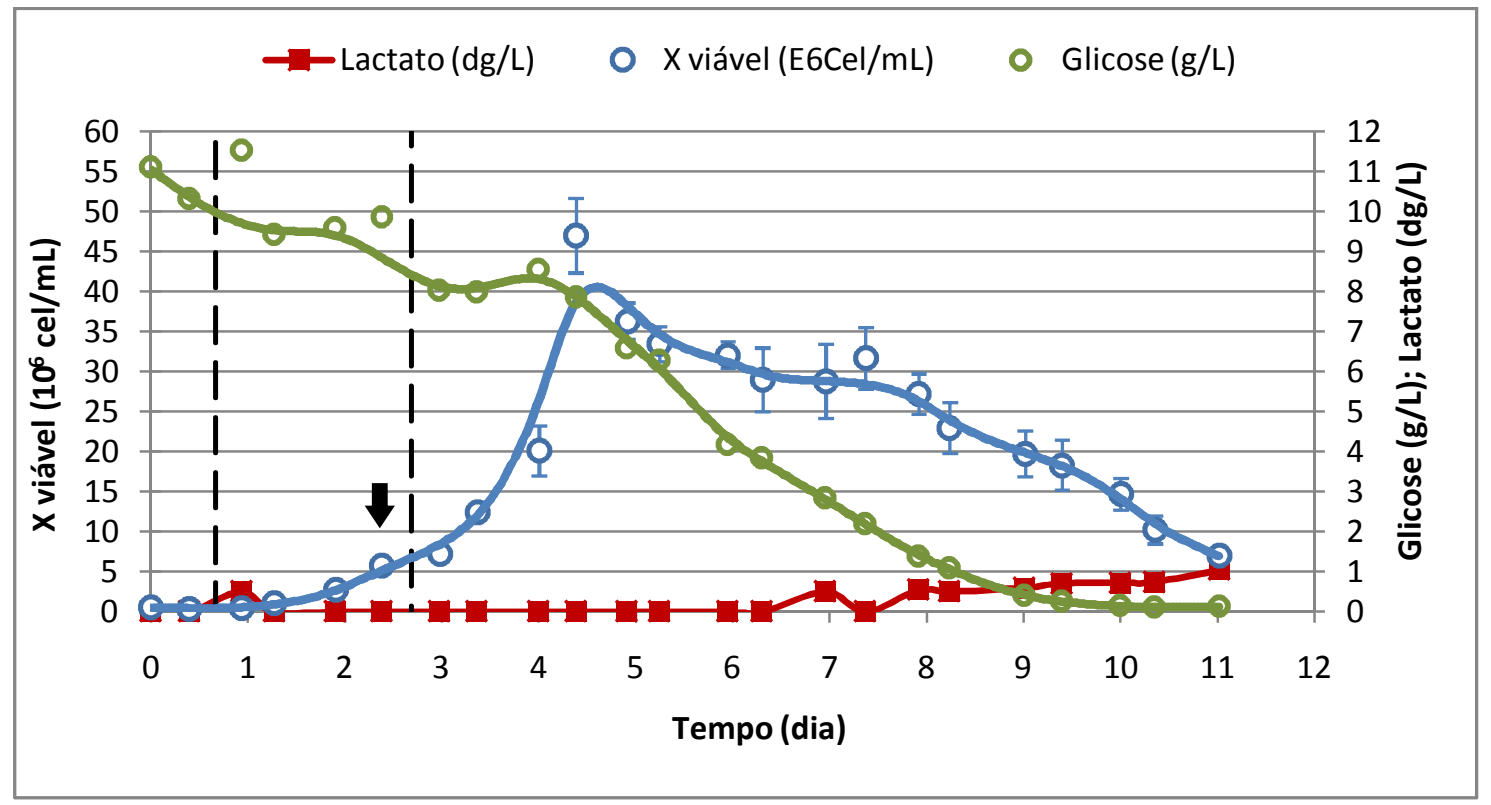

Gráfico 4: Concentração de Glicose e Lactato ao longo do tempo na Batelada 1.

Algumas das amostras realizadas no HPLC não detectaram a presença de lactato, pois a coluna utilizada não detecta valores inferiores a 0,02 g/L. A concentração máxima de lactato produzido foi de $0,10 \mathrm{~g} / \mathrm{L}$. Esta concentração de ácido lático é significativamente mais baixa que as concentrações obtidas com células de mamíferos, as quais podem apresentar concentrações de até $2,0 \mathrm{~g} / \mathrm{L}$ (AMABLE e BUTLER, 2008). Para facilitar a compreensão dos dados, as 
concentrações de lactato estão apresentadas no Gráfico 5 em dg/L para estar no mesmo eixo da concentração de glicose ( $g / L)$.

Concentrações muito baixas de lactato também foram observadas nos trabalhos de Aguiar (2010), Ventini et al.(2010), Galesi et al. (2008) e Swiech et al. (2008b), porém este metabólito pode chegar a concentrações de 3,0 g/L em diferentes condições (BOVO et al., 2008; BATISTA et al., 2008). Esta alteração no comportamento da célula confirma a hipótese de Bovo et al. (2008) de que esta linhagem celular apresenta grande variabilidade em suas respostas metabólicas às condições de cultivo.

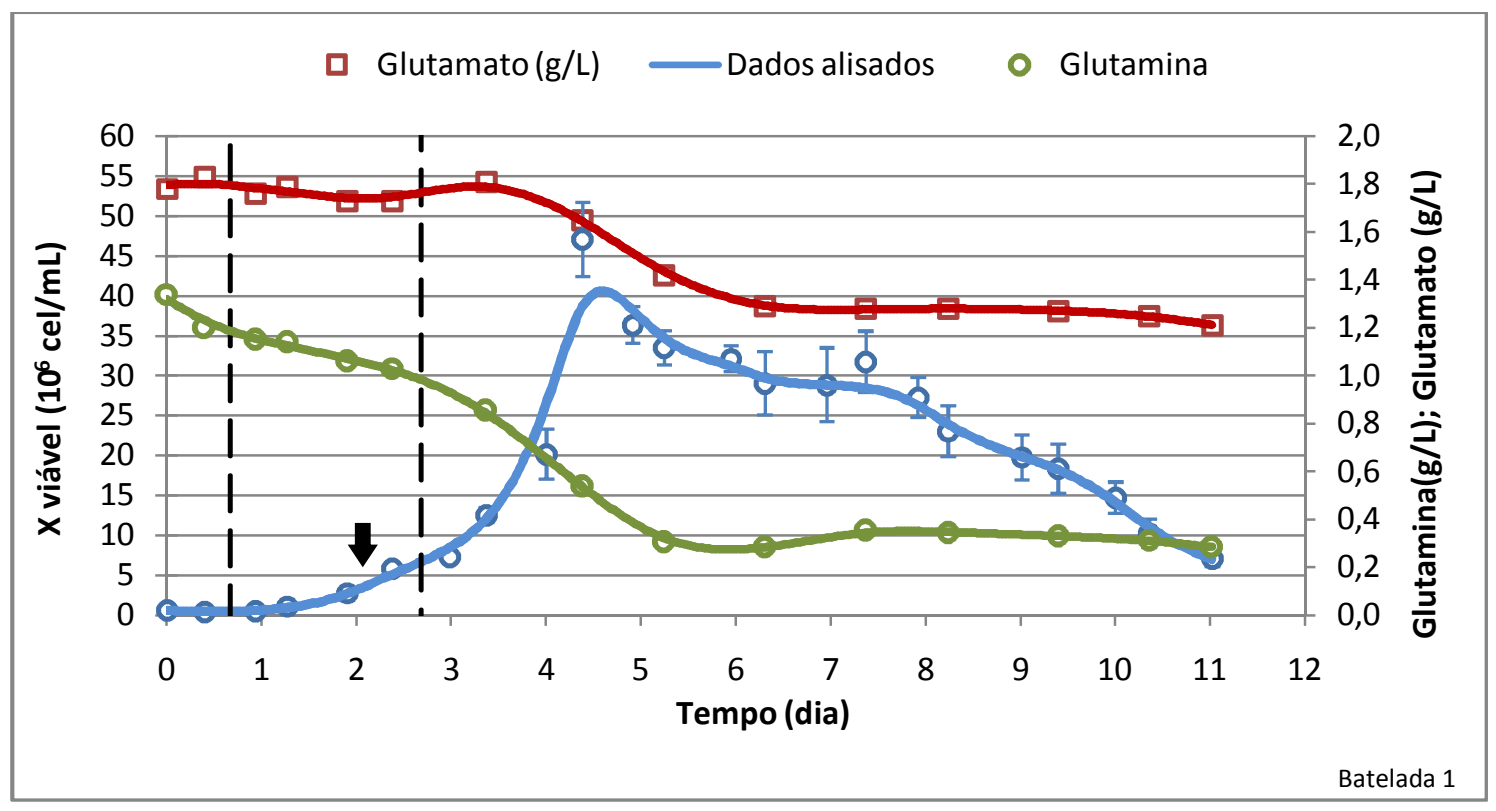

Gráfico 5: Concentração de glutamina e glutamato residual na Batelada 1.

Devido a alguns problemas com o analisador (YSI), as análises de glutamina e glutamato da Batelada 1 foram realizadas um ano após o ensaio (Gráfico 5). As amostras estavam armazenadas em $-20^{\circ} \mathrm{C}$ e foram descongeladas duas vezes antes da dosagem correta. Com isso, uma parte da glutamina pode ter sido degradada. Isso explicaria o valor dosado de apenas 1,34 $\mathrm{g} / \mathrm{L}$ de glutamina no meio de cultura, ao passo que, em meio fresco, foi observado valores entre 1,6 e $1,8 \mathrm{~g} / \mathrm{L}$.

No entanto, mesmo considerando o fato de que a glutamina se degradou ao longo do tempo, pode-se observar no Gráfico 5 que no fim da fase exponencial há ainda, aproximadamente, 1,0 g/L de glutamina residual, confirmando a hipótese de que a glutamina não é o substrato limitante no meio SF 900 II. Pode-se notar 
também que a glutamina foi mais consumida até $05^{\circ}$ dia, após esse período a concentração ficou em torno de $0,3 \mathrm{~g} / \mathrm{L}$. O consumo total deste substrato foi de $1 \mathrm{~g} / \mathrm{L}$. O mesmo perfil do consumo de glutamina foi observado por Ventini et al. (2010) e Aguiar (2010).

Com relação ao glutamato, o perfil de consumo deste aminoácido é caracterizado por ser pouco consumido ao longo de todo o cultivo, também apresentado no Gráfico 5. Nesse ensaio o consumo total deste foi igual a 0,6 g/L, no qual o maior consumo ocorreu após a fase exponencial.

Foi possível calcular o fator de conversão glicose à célula $\left(\mathrm{Y}_{\mathrm{X} / \mathrm{GLC}}{ }^{\mathrm{EXP}}\right)$ durante a fase exponencial através da regressão linear da curva $X_{v}=f(G l i c o s e)$. A oscilação na curva de consumo de glicose pode explicar a baixa correlação entre estas variáveis $\left(R^{2}=0,68\right)$, mesmo removendo alguns pontos da curva $X v=f(G l i c o s e) .0$ valor encontrado foi igual a $1,4 \times 10^{9} \mathrm{cel} / \mathrm{g}$ de glicose.

$\mathrm{Na}$ literatura não há valores de fatores de conversão para as células S2MtGPV, porém pode-se comparar com as células S2AcGPV. Aguiar (2010) calculou o fator de conversão de glicose a célula em cultivos com células S2AcGPV em meio TC100 em diferentes condições de cultivo. Os valores alcançados de $\mathrm{Y}_{\mathrm{X} / \mathrm{GLC}}{ }^{\mathrm{EXP}}$ foram entre 0,7 a $2,6 \times 10^{9} \mathrm{cel} / \mathrm{g}$. Apesar de estarem em condições de cultivo diferentes deste trabalho, a faixa de valores encontrado pelo autor abrange 0 valor calculado na Batelada 1. Swiech et al. (2008b), com células S2AcGPV em meio SF 900 II encontraram 3,2 × $10^{9}$ cel/g, ou seja, 2,3 vezes maior que na Batelada 1.

O fator de conversão de glutamina a célula $\left(\mathrm{Y}_{\mathrm{X} / \mathrm{GLN}}{ }^{\mathrm{EXP}}\right)$ encontrado foi de $30 \mathrm{x}$ $10^{9} \mathrm{cel} / \mathrm{g}$. Esse valor é muito baixo quando comparado com Aguiar (2010), que encontrou valores entre 0,047 e $1,92 \times 10^{7} \mathrm{cel} / \mathrm{g}$. Porém, é próximo ao valor máximo encontrado por Swiech (2007), que foi igual a $25 \times 10^{9} \mathrm{cel} / \mathrm{g}$.

O fator de conversão $Y_{L A C / G L C}$ não foi calculado, pois não há pontos suficientes da concentração de lactato na fase exponencial de crescimento.

Com relação à GPV, a maior produtividade alcançada neste ensaio foi $30 \mu \mathrm{g} / \mathrm{L}$.h. No Gráfico 6 têm-se a quantidade de GPV expressa durante o ensaio em $\mu \mathrm{g} / \mathrm{L}$ e $\mu \mathrm{g} / 10^{7}$ células, conforme análise descrita na seção 4.4.4. 


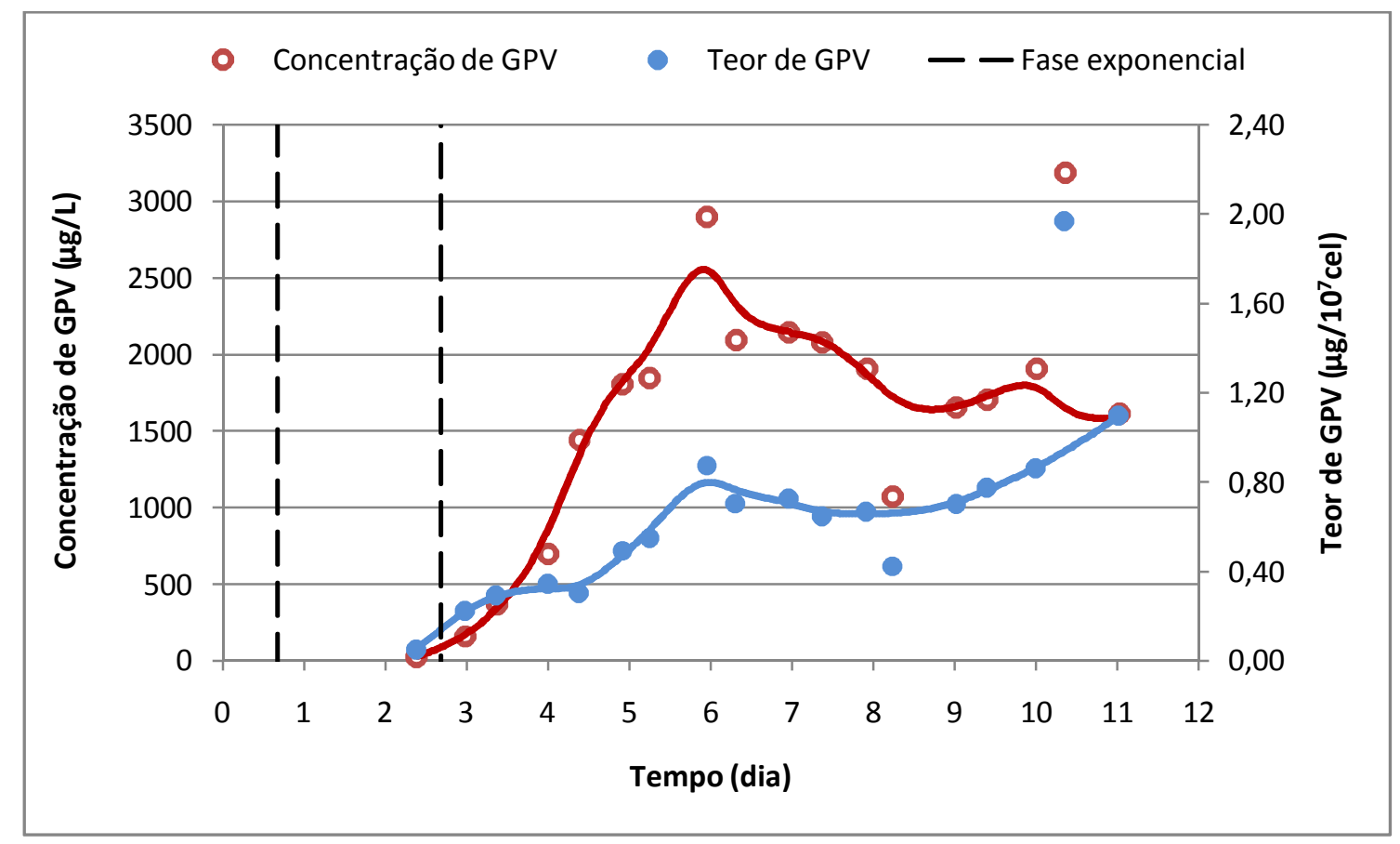

Gráfico 6: Concentração e Teor Específico de GPV ao longo do Tempo.

A concentração máxima de GPV ao longo do ensaio foi de aproximadamente $2500 \mu \mathrm{g} / \mathrm{L}$ e o teor de GPV máximo neste ensaio ficou em torno foi de $1 \mu \mathrm{g} / 10^{7}$ células. Este valor foi menor que valor alcançado por Ventini et al. (2010), no qual o teor de GPV máximo foi de $1,3 \mu \mathrm{g} / 10^{7}$ células. Porém, a concentração de GPV neste trabalho foi 1,5 vezes maior, devido a uma maior concentração de células. Estas variações podem estar relacionadas à concentração de oxigênio dissolvido, visto que o banco de células utilizado e as condições de cultivo foram as mesmas com exceção da concentração de oxigênio dissolvido.

\subsubsection{Batelada 2}

O segundo ensaio denominado Batelada 2 foi realizado com a linhagem celular constitutiva S2AcGPV. A aeração foi realizada por borbulhamento de $\operatorname{Ar}$ e $\mathrm{N}_{2}$ até o terceiro dia, após este período a aeração passou a ser feita com $\mathrm{O}_{2}$ e $\mathrm{N}_{2}$.

O oxigênio dissolvido foi controlado em $30 \%$, a velocidade de agitação foi controlada em $90 \mathrm{rpm}$ e a temperatura foi mantida em $28^{\circ} \mathrm{C}$. $\mathrm{O}$ inóculo inicial foi de $3,05 \times 10^{5} \mathrm{cel} / \mathrm{mL}$. Pode-se observar que $\mathrm{oH}$ deste ensaio também permaneceu numa faixa entre 6 e 7. Neste cultivo o monitoramento do $\mathrm{pH}$ foi prejudicado, pois o 
eletrodo sofreu algum dano no início do ensaio e só pôde ser trocado após o mesmo. Com isso, as medidas de $\mathrm{pH}$ foram realizadas em um eletrodo externo em amostras retiradas 2 vezes ao dia. No Gráfico 7, podem-se observar as principais variáveis deste ensaio.

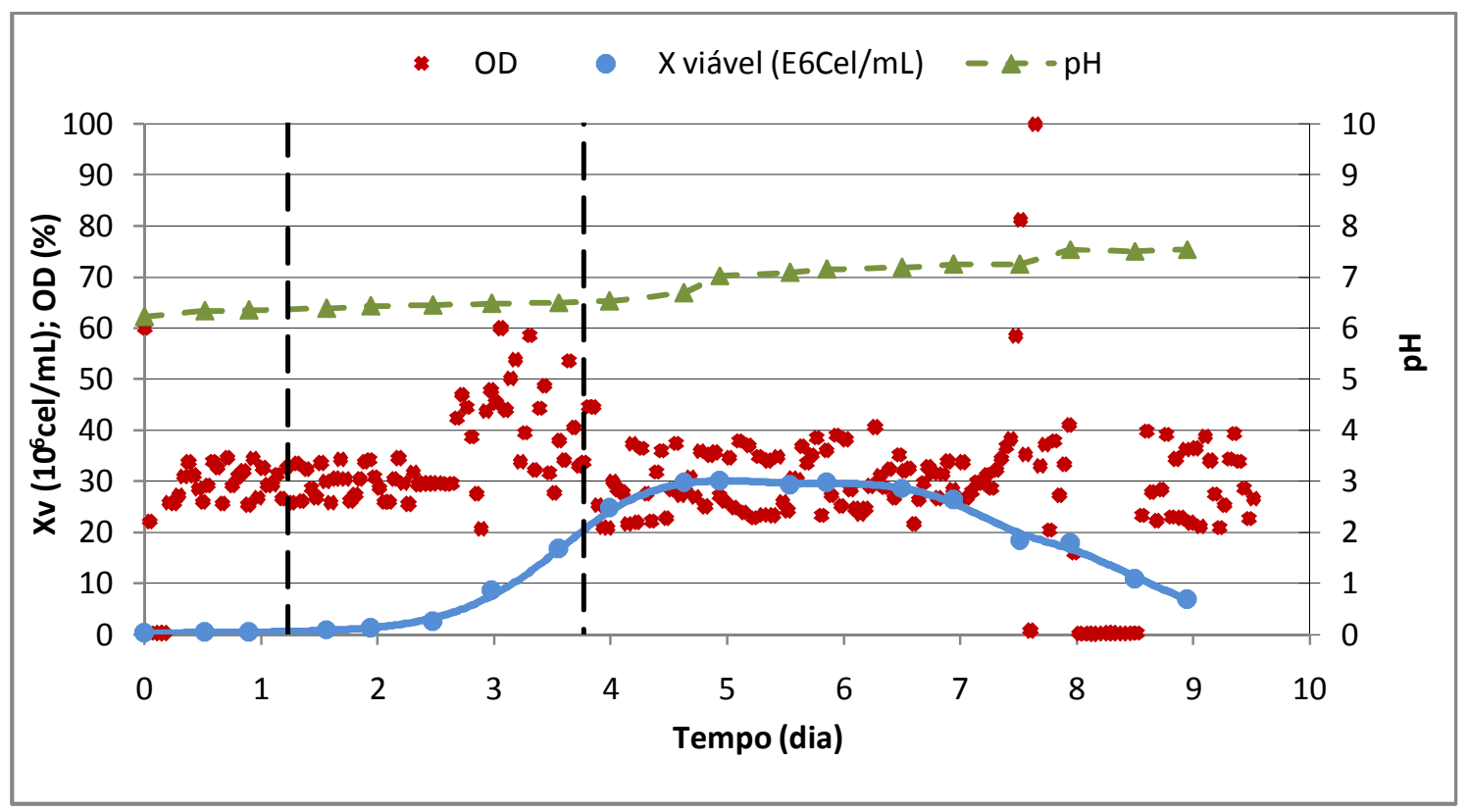

Gráfico 7: OD, Frequência de Agitação, Temperatura, pH e a Concentração de células viáveis da Batelada 2 ao longo do tempo.

O tempo de duração do ensaio foi de 9 dias, o ensaio foi encerrado, pois a viabilidade celular era menor que $50 \%$. A máxima concentração celular atingida foi de $30 \times 10^{6} \mathrm{cel} / \mathrm{mL}$, como mostrado no Gráfico 8. 


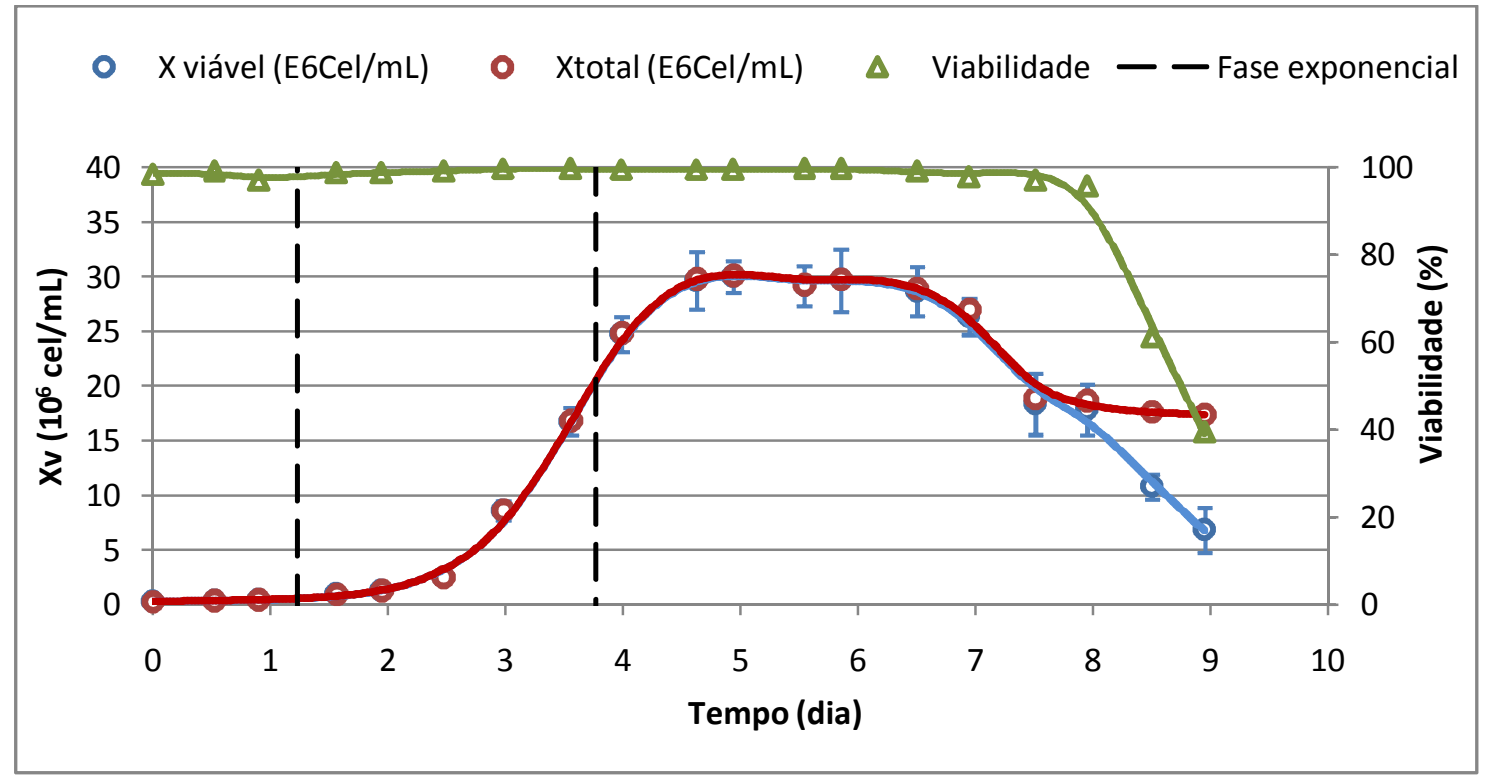

Gráfico 8: Crescimento Celular das Células S2AcGPV ao longo do tempo na Batelada 2.

Considerando que a fase exponencial de crescimento se iniciou em 1,2 dias e terminou em 3,6 dias, a velocidade específica máxima calculada neste cultivo foi igual a $1,5 \mathrm{dia}^{-1}$ (Gráfico 9a). Este valor é próximo ao encontrado por Ventini et al. (2010) $\left(1,6\right.$ dia $\left.^{-1}\right)$ sob as mesmas condições de cultivo. No entanto, 3 vezes maior que no meio TC 100 (AGUIAR, 2010). O perfil da curva da velocidade específica de crescimento ao longo do tempo pode ser observado na Gráfico 9b.
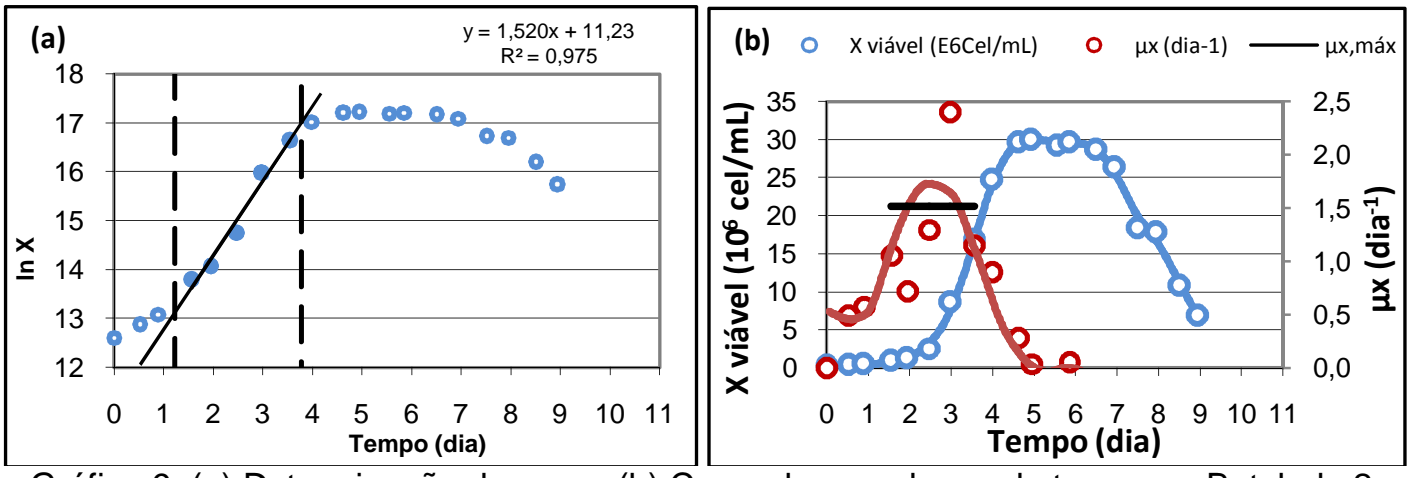

Gráfico 9: (a) Determinação de $\varepsilon_{\text {máx }}$ e (b) Curva de $\varepsilon_{x}$ ao longo do tempo na Batelada 2.

Foram quantificadas as concentrações de glicose e o lactato do ensaio 2 por HPLC, conforme descrito na Seção 4.5.2. O HPLC detectou lactato apenas em uma das amostras, ou seja, ao longo do cultivo não foi observado concentrações de lactato superiores a $0,02 \mathrm{~g} / \mathrm{L}$.

A glicose não foi totalmente consumida, restando ainda $1,9 \mathrm{~g} / \mathrm{L}$ no fim do cultivo. Considerando que a fase exponencial se estendeu até 3,6 dias de cultivo e 
que a concentração de glicose indicava aproximadamente $8,0 \mathrm{~g} / \mathrm{L}$, é pouco provável que o fim da fase exponencial de crescimento tenha ocorrido em função da falta de glicose, indicando a presença de outro nutriente limitante (fato também observado por Ventini et al. (2010), Aguiar (2010), Pamboukian et al. (2008) e Swiech et al. (2008a). O Gráfico 10 mostra o perfil da concentração de glicose e de lactato.

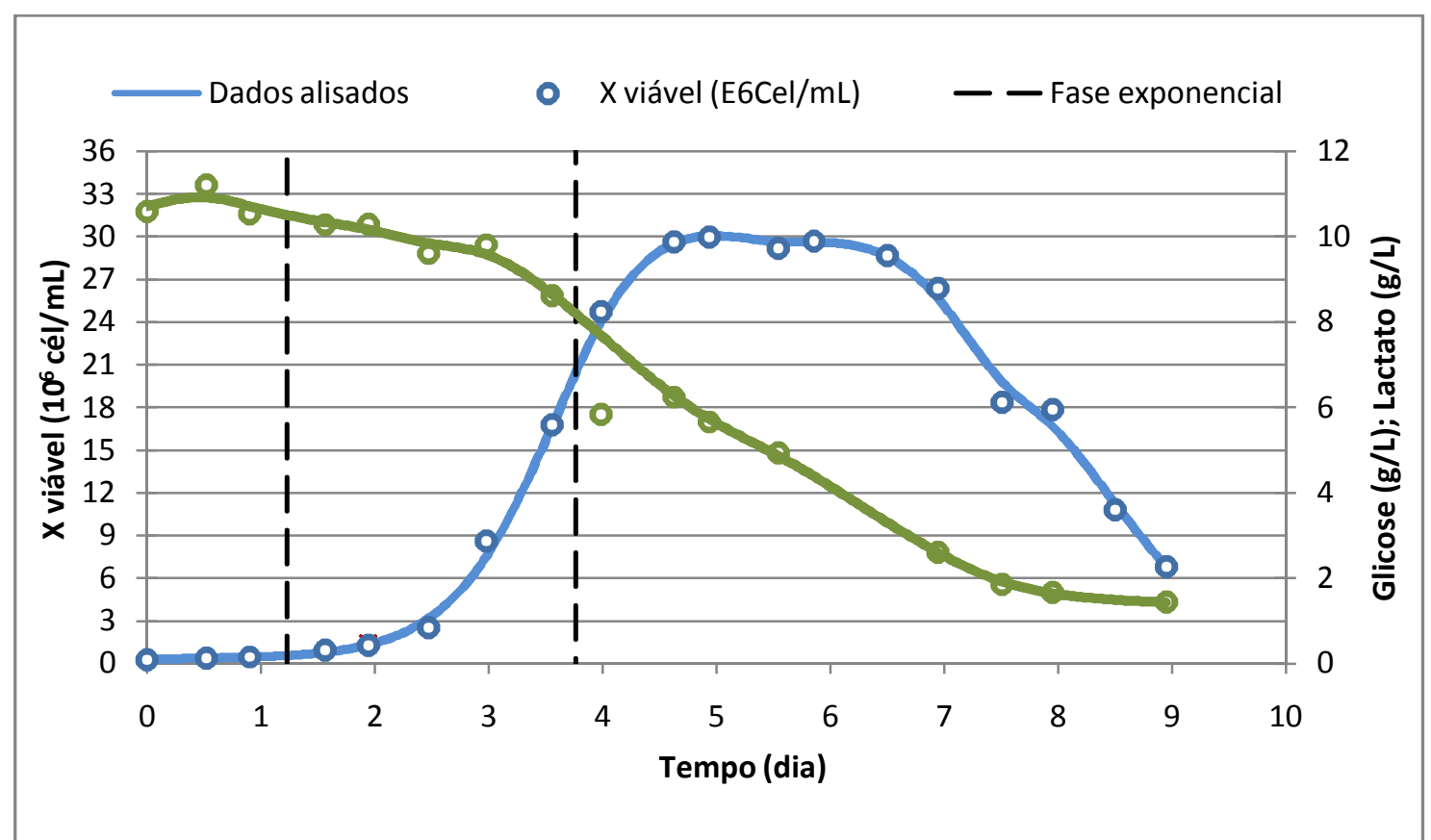

Gráfico 10: Concentração de Glicose e de Lactato ao longo do tempo na Batelada 2.

Os perfis da concentração de glutamina e de glutamato estão representados no Gráfico 11. Pode-se notar que da mesma forma que na Batelada 1, os perfis de ambos aminoácidos foram semelhantes e o consumo total também.

A maior consumo de glutamina foi observado entre os dias 1 e 5. Após este período a concentração residual de glutamina permaneceu praticamente constante, atingindo $0,08 \mathrm{~g} / \mathrm{L}$ no fim do cultivo. $O$ consumo total deste substrato foi de $1,07 \mathrm{~g} / \mathrm{L}$.

O maior consumo de glutamato observado foi após a fase exponencial. A consumo de glutamato total foi de $0,5 \mathrm{~g} / \mathrm{L}$. 


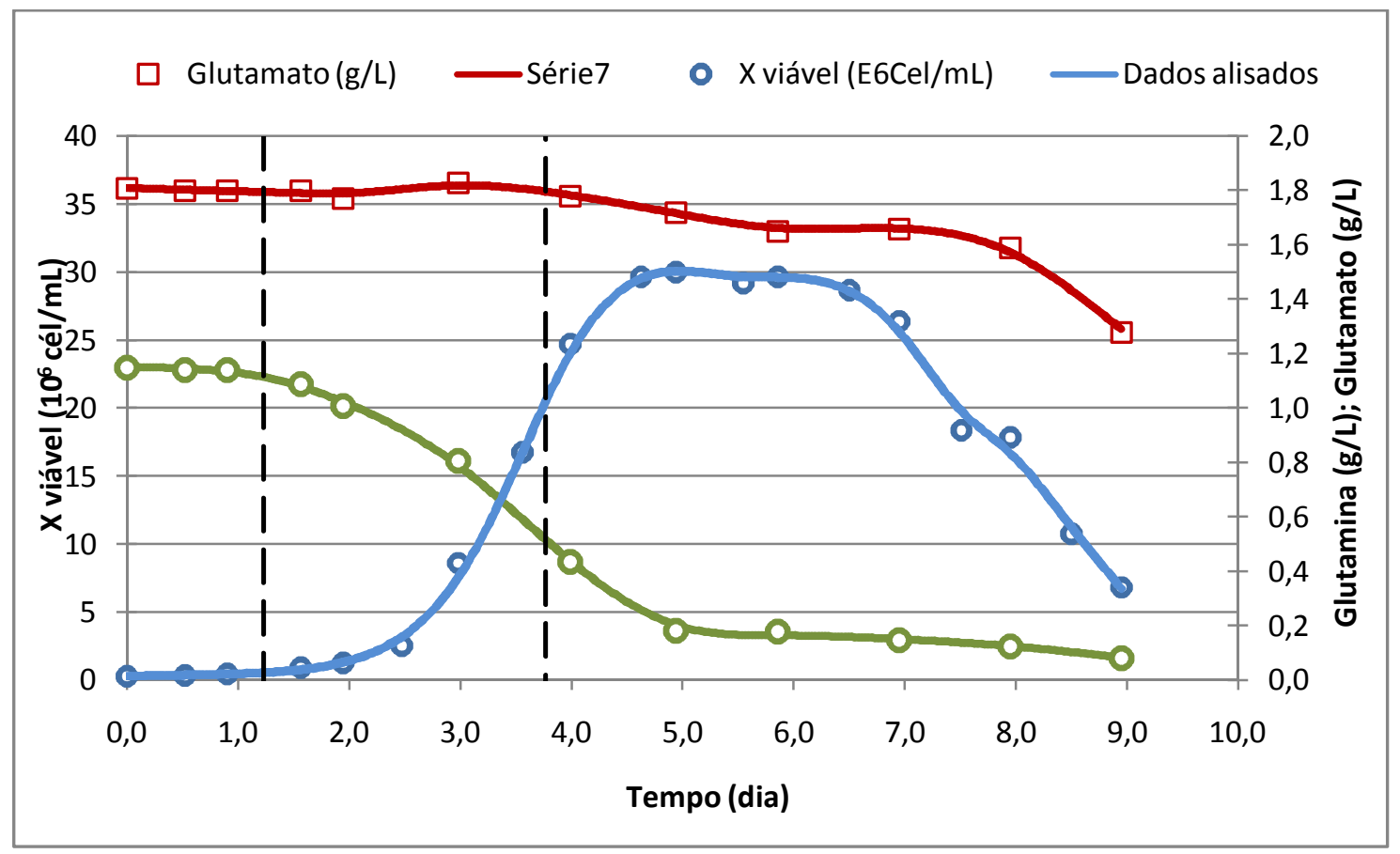

Gráfico 11: Concentração de Glutamina e de Glutamato ao longo do tempo na Batelada 2.

Foi possível calcular o fator de conversão glicose à célula durante a fase exponencial desse cultivo. $O$ valor encontrado foi igual a $8 \times 10^{9} \mathrm{cel} / \mathrm{g}$ de glicose. Este valor é praticamente 6 vezes maior que valor encontrado na batelada com as células S2MtGPV, ou seja, as células S2AcGPV consomem relativamente mais glicose.

No meio TC 100, o maior valor encontrado de $Y_{X / G L C}{ }^{\text {EXP }}$ foi de $2,7 \times 10^{9} \mathrm{cel} / \mathrm{g}$, ou seja, 2,8 vezes menor que no meio SF 900 II (AGUIAR, 2010).

Com relação ao fator de conversão $\mathrm{YXJGLN}^{\mathrm{EXP}}$, o valor encontrado foi de $23 \mathrm{x}$ $10^{9} \mathrm{cel} / \mathrm{g}$. Esse fator de conversão é próximo ao encontrado na Batelada $1 \mathrm{com}$ as células S2MtGPV e também ao valor encontrado na batelada realizada por Swiech et al. (2008b) sob condições próximas de cultivo (Bio 5) que foi $24,9 \times 10^{9} \mathrm{cel} / \mathrm{g}$. No entanto, é bem diferente $\left(0,0472\right.$ a $\left.1,92 \times 10^{7} \mathrm{cel} / \mathrm{g}\right)$ do fator de conversão para 0 meio TC 100 AG modificado (AGUIAR, 2010).

Pela mesma razão da Batelada 1, o fator de conversão $Y_{\text {LAC/GLC não foi }}$ calculado, pois não há pontos suficientes da concentração de lactato na fase exponencial de crescimento. 
Com relação à produção da glicoproteína, a concentração máxima de GPV expressa durante o ensaio foi aproximadamente $2500 \mu \mathrm{g} / \mathrm{L}$ e a máxima produção específica de GPV foi de 1,0 $\mu \mathrm{g} / 107 \mathrm{cel}$, como mostrado no Gráfico 12.

Pode-se observar que o maior teor de GPV ocorre após a fase exponencial e que durante esta fase ela é praticamente constante. Ventini et al. (2010) também observaram este perfil, ou seja, o maior teor de GPV foi logo após o fim da fase exponencial.

O perfil do teor de GPV em meio TC 100 AG modificado difere um pouco, pois apresenta um perfil crescente durante a fase exponencial e uma ligeira diminuição após o seu valor máximo (AGUIAR, 2010).

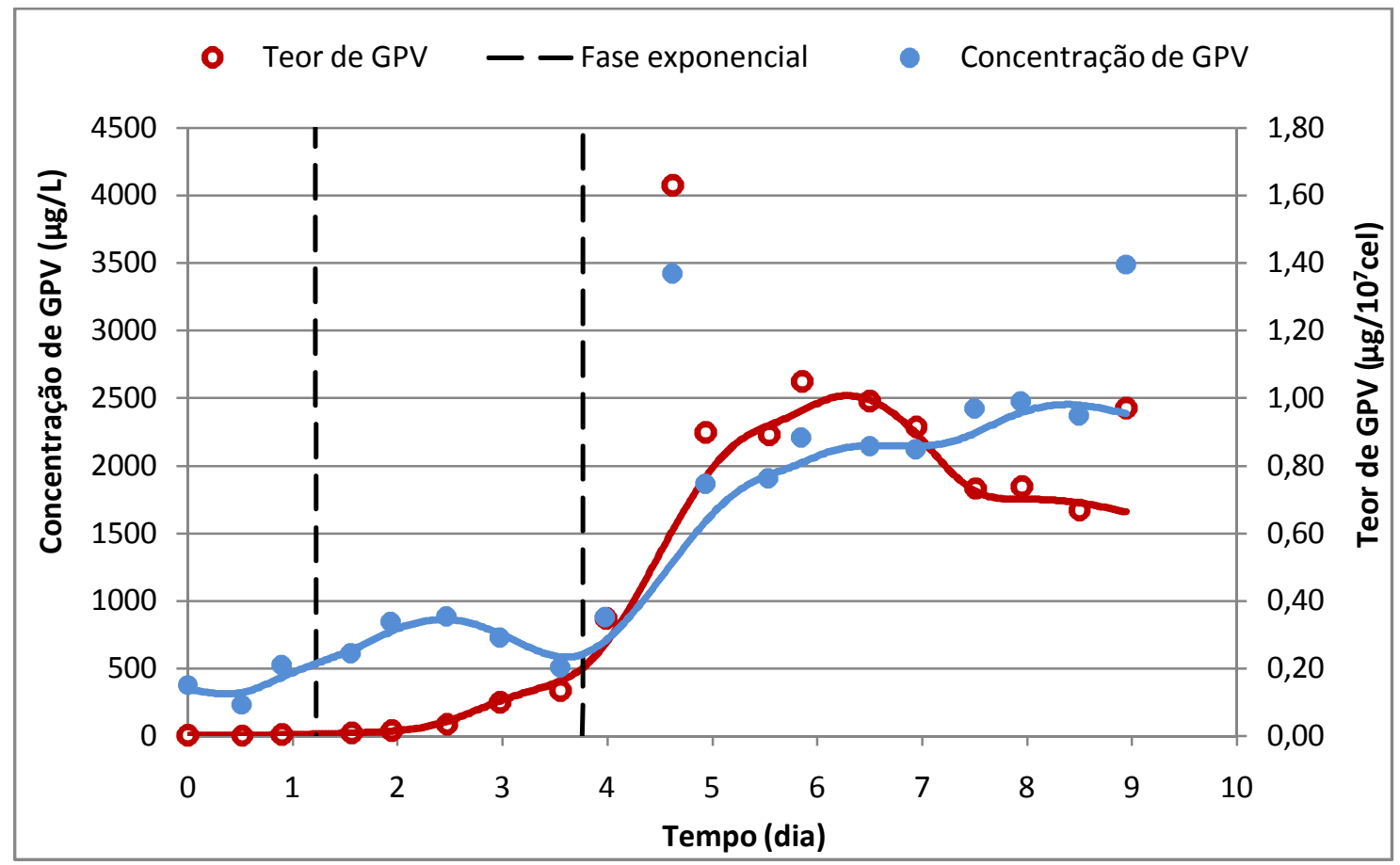

Gráfico 12: Concentração e teor de GPV ao longo do tempo na Batelada 2.

Ainda na Batelada 2, com o objetivo de verificar se existe uma correlação entre a concentração celular total encontrada através da contagem na câmara de Neubauer com a biomassa (massa seca das células) e com a leitura de absorbância, foram realizados as três metodologias para a determinação da concentração celular.

O Gráfico 13 mostra que há uma correlação entre a turbidez e a concentração celular total com um coeficiente de correlação de 0,94. 


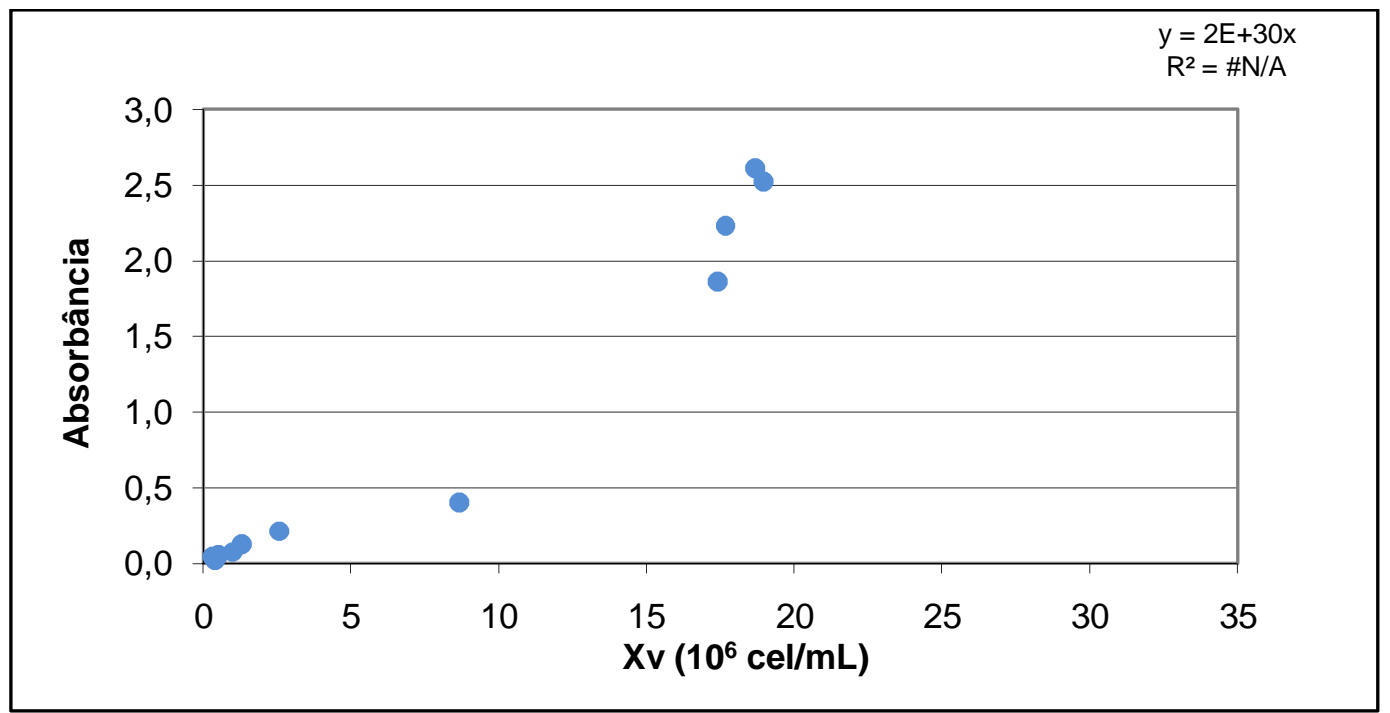

Gráfico 13: Correlação entre absorbância e concentração celular total.

Também foi possível correlacionar a concentração celular em massa seca e a concentração total celular, sendo o coeficiente de correlação $R^{2}$ igual a 0,95 (Gráfico 14). No entanto, vale ressaltar que a filtração a vácuo com membrana de $0,45 \mu \mathrm{m}$ se torna bastante complicada à medida que o tempo de cultivo aumenta. Isso pode ser explicado pelo fato de que mais metabólitos e células são formados ao longo do tempo. Esta análise não foi realizada em todos os pontos amostrados, pois requeria um elevado volume de amostra $(5 \mathrm{~mL})$.

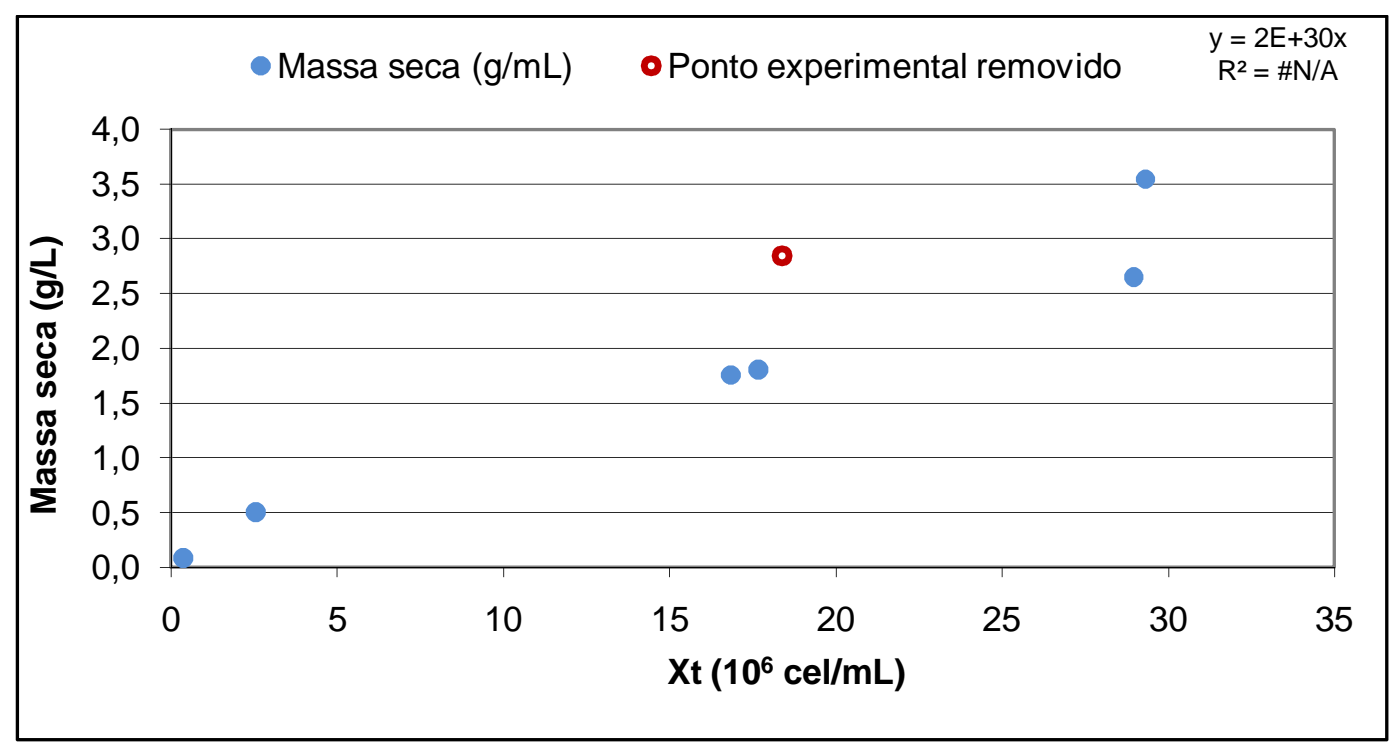

Gráfico 14: Correlação entre massa seca de células e concentração celular total.

Com a equação do gráfico $X t=f($ Massa seca) (Gráfico 14), foi possível descobrir o peso de uma única célula que representa $1,06 \times 10^{-10} \mathrm{~g}$, ou seja, $106 \mathrm{pg}$. 
O peso das células de inseto Sf9 é, aproximadamente, 600 pg, praticamente seis vezes maior (CHIOU et al., 2000; FERRANCE et al., 1993). O peso das células S2 também é menor (2,5 a 3,7 vezes) quando comparada com células de mamífero hibridoma e CHO. O peso das células hibridoma 3A21 varia entre 270 e $375 \mathrm{pg}$ (OMASA et al., 2010) e o peso da célula CHO é igual a 390 pg (NYBERG et al., 1999).

\subsubsection{Comparação entre as Bateladas 1 e 2}

Nestes dois ensaios em batelada, pode-se verificar que a linhagem S2MtGPV atinge, em relação a S2AcGPV:

- Uma maior concentração celular;

- Uma velocidade específica máxima de crescimento similar $(1,6 \pm 0,1)$;

- Uma menor conversão de glicose a células na fase exponencial;

- Uma maior conversão de glutamina a células na fase exponencial;

- O mesmo teor máximo de GPV;

- A mesma concentração máxima de GPV;

- Uma maior produtividade.

Estes dados são mostrados na tabela 6 .

Tabela 6: Comparação entre a Batelada 1 e a Batelada 2.

\begin{tabular}{ccc}
\hline Parâmetros & $\begin{array}{c}\text { Batelada 1 } \\
\text { (S2MtGPV) }\end{array}$ & $\begin{array}{c}\text { Batelada 2 } \\
\text { (S2AcGPV) }\end{array}$ \\
\hline \hline $\mathrm{X}_{\text {MÁx }}\left(\mathrm{x} 10^{6} \mathrm{cel} / \mathrm{mL}\right)$ & 41,0 & 30,0 \\
\hline$\mu_{\mathrm{MÁx}}\left(\mathrm{dia}^{-1}\right)$ & 1,70 & 1,50 \\
\hline $\mathrm{Y}_{\mathrm{X} / \mathrm{GLC}}(\mathrm{exp})(\mathrm{cel} / \mathrm{g}$ glicose) & $1,4 \times 10^{9}$ & $8 \times 10^{9}$ \\
\hline $\mathrm{Y}_{\mathrm{X} / \mathrm{GLN}}(\mathrm{exp})(\mathrm{cel} / \mathrm{g}$ glutamina) & $30 \times 10^{9}$ & $23 \times 10^{9}$ \\
\hline $\mathrm{GPVe}$ máxima $\left(\mu \mathrm{g} / 10^{7} \mathrm{cel}\right)$ & 1,0 & 1,0 \\
\hline Conc. máxima de GPV $(\mu \mathrm{g} / \mathrm{L})$ & 2500 & 2500 \\
\hline Produtividade máxima $(\mu \mathrm{g} / \mathrm{L} . \mathrm{h})$ & 30 & 18 \\
\hline
\end{tabular}


Com relação ao teor de GPV e as concentrações de GPV em $\mu \mathrm{g} / \mathrm{L}$ para estes dois ensaios, pode-se notar que não há diferenças significativas entre as duas variáveis (Gráfico 15).
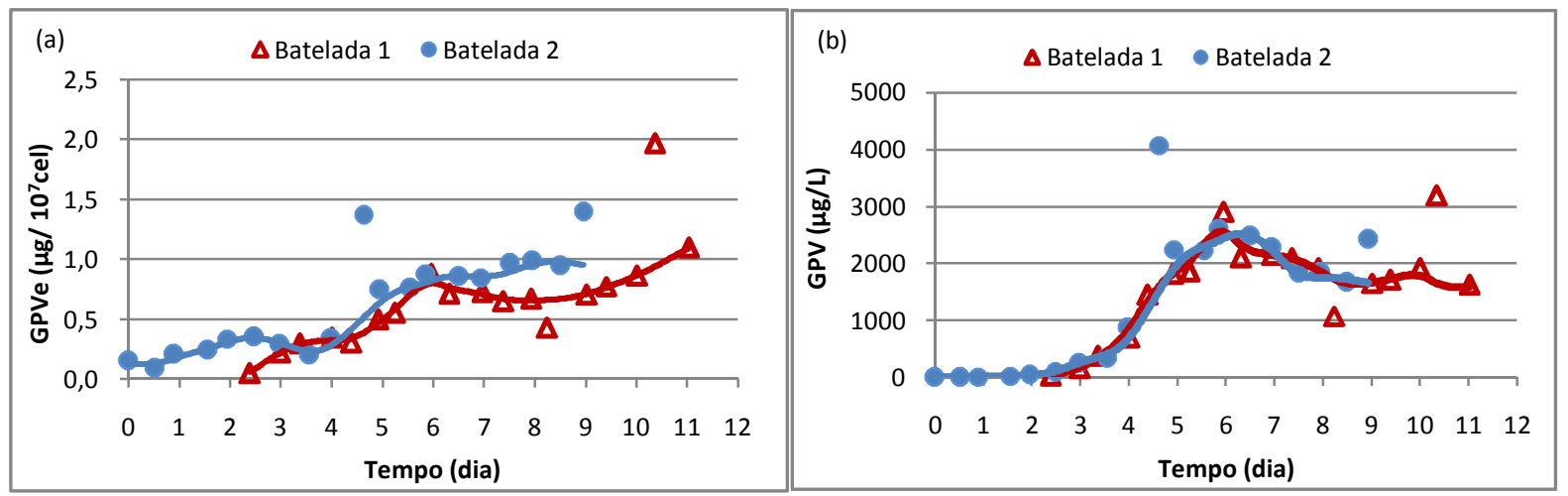

Gráfico 15: (a) Comparação da GPV específica e (b) a concentração de GPV entre a Batelada 1 e Batelada 2.

Comparando ainda os dois ensaios, porém com relação à produtividade, pode-se notar que há diferenças entre as duas linhagens, a S2MtGPV alcançou uma produtividade máxima 1,7 vezes maior que na S2AcGPV (Gráfico 16).

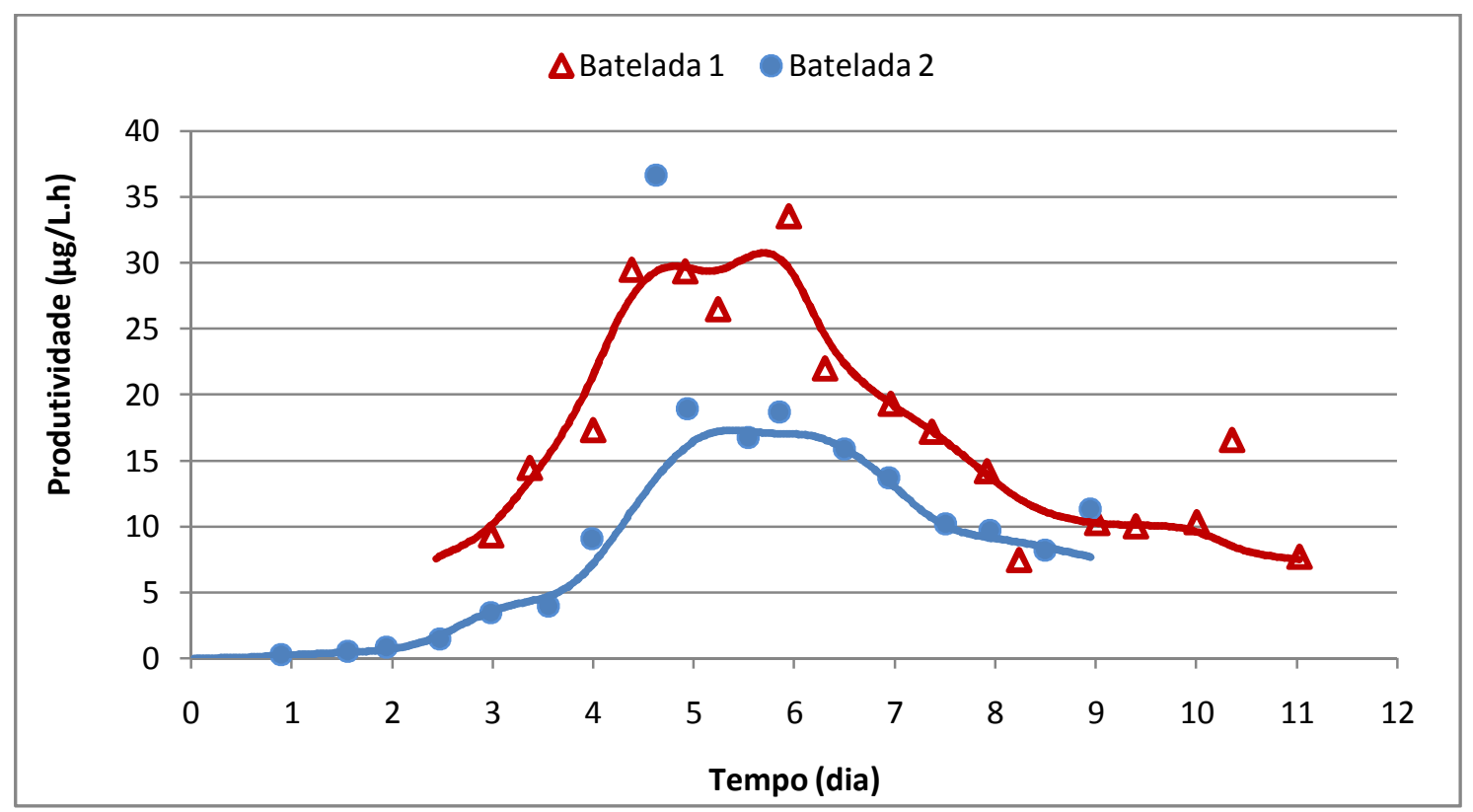

Gráfico 16: Comparação da produtividade entre a Batelada 1 e Batelada 2

Apesar de estes resultados indicarem que a célula S2MtGPV seja mais produtiva que a S2AcGPV, não foi possível afirmar qual a linhagem mais adequada para a realização de cultivos em processos contínuos. Com isso, foi realizado um conjunto de experimentos em schotts com células S2MtGPV para simular um ensaio 
contínuo com indução com sulfato de cobre e assim, realmente estabelecer qual a linhagem celular será utilizado para este fim.

\subsection{ENSAIOS EM SCHOTT PARA TESTES COM O SULFATO DE COBRE $\left(\mathrm{CuSO}_{4}\right)$}

De forma a obter resultados mais concretos com relação à escolha da célula para a realização do ensaio em processo contínuo, foram realizados experimentos em frascos schott com a linhagem S2MtGPV.

Sabe-se que essa linhagem necessita de uma indução com sulfato de cobre $\left(\mathrm{CuSO}_{4}\right)$ para expressar a proteína (SANTOS et al., 2007). Esta indução é feita quando a concentração celular atinge aproximadamente $5 \times 10^{6} \mathrm{cel} / \mathrm{mL}$. Segundo o mesmo autor $0 \mathrm{CuSO}_{4}$, quando em altas concentrações, pode ser tóxico para as células. No entanto, para um processo em batelada este fato não chega a ser um problema, uma vez que se conhece a concentração de indutor necessária para expressar a proteína de interesse sem prejudicar as células.

Porém, num processo contínuo a indução com sulfato de cobre gera algumas dúvidas como, por exemplo, a forma pela qual ocorrerá o processo de indução. Uma resposta seria a indução contínua mantendo a concentração ideal para a indução diretamente no meio de alimentação. Porém, não é conhecido o comportamento do processo ao longo do tempo, isto é, será que as células sob uma constante indução conseguiriam manter altas velocidades específicas de crescimento? Seria necessária uma concentração maior de indutor para expressar a GPV? Será que, ao longo do tempo, uma concentração menor de metal seria necessária para a expressão? Ou ainda, será que com uma única indução as novas gerações de células expressariam a GPV naturalmente sem a presença do indutor?

Para resolver essas questões foram realizados quatro diferentes tipos de testes em schott com o sulfato de cobre $\left(\mathrm{CuSO}_{4}\right)$, todos em duplicata (como mostrado no item 4.6.1). O objetivo principal foi avaliar a viabilidade celular e a concentração de GPV ao longo do tempo com diferentes concentrações do indutor. Com isso, pode-se simular o que poderá acontecer com estas células num processo contínuo em diferentes situações. 
Frisa-se que em todos os schotts metade do volume útil foi trocado a cada dois dias. Os resultados mostraram que a velocidade específica de crescimento $\left(\mu_{\mathrm{x}}\right.$ $\left[\mathrm{dia}^{-1}\right]$ ) decresceu ao longo do tempo em todos os testes realizados. Porém, essa diminuição de $\mu_{x}$ ocorreu de uma forma mais suave no teste $D$, no qual a concentração de sulfato de cobre sofreu diluições sucessivas. O gráfico 17 apresenta estes resultados.

O cálculo de $\mu_{x}$ neste caso foi realizado da seguinte forma:

$$
\mu=\frac{-}{-}
$$

Onde: $X_{i}$ representa a concentração inicial da batelada repetida, ou seja, após a troca $50 \%$ do volume e $X_{f}$ é a concentração celular final, isto é, antes da troca, nos instantes $t_{i}$ e $t_{f}$ respectivamente.

Pode-se notar no Gráfico 17 que ao longo do tempo, a velocidade específica de crescimento de alguns schotts foi diminuindo até não haver mais células. Por isso, decorridos 21 dias, o último ponto do Gráfico 17 conta apenas com dados do schott D.

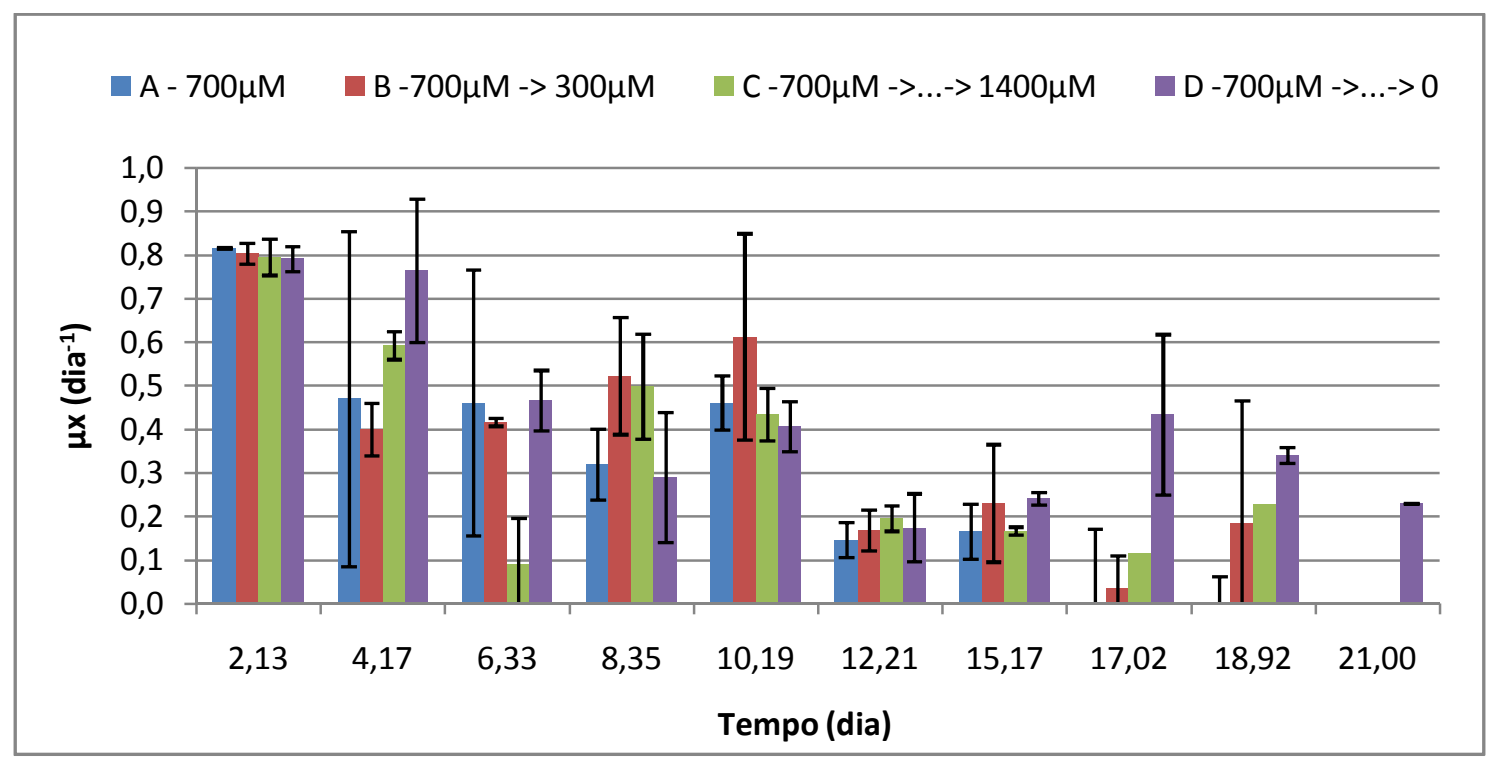

Gráfico 17: Velocidade específica de crescimento ao longo do tempo nos experimentos em schott.

O teor de GPV praticamente se manteve constante em todos os testes como mostrado no Gráfico 18. Ou seja, a célula permanece expressando a mesma quantidade de proteína. 


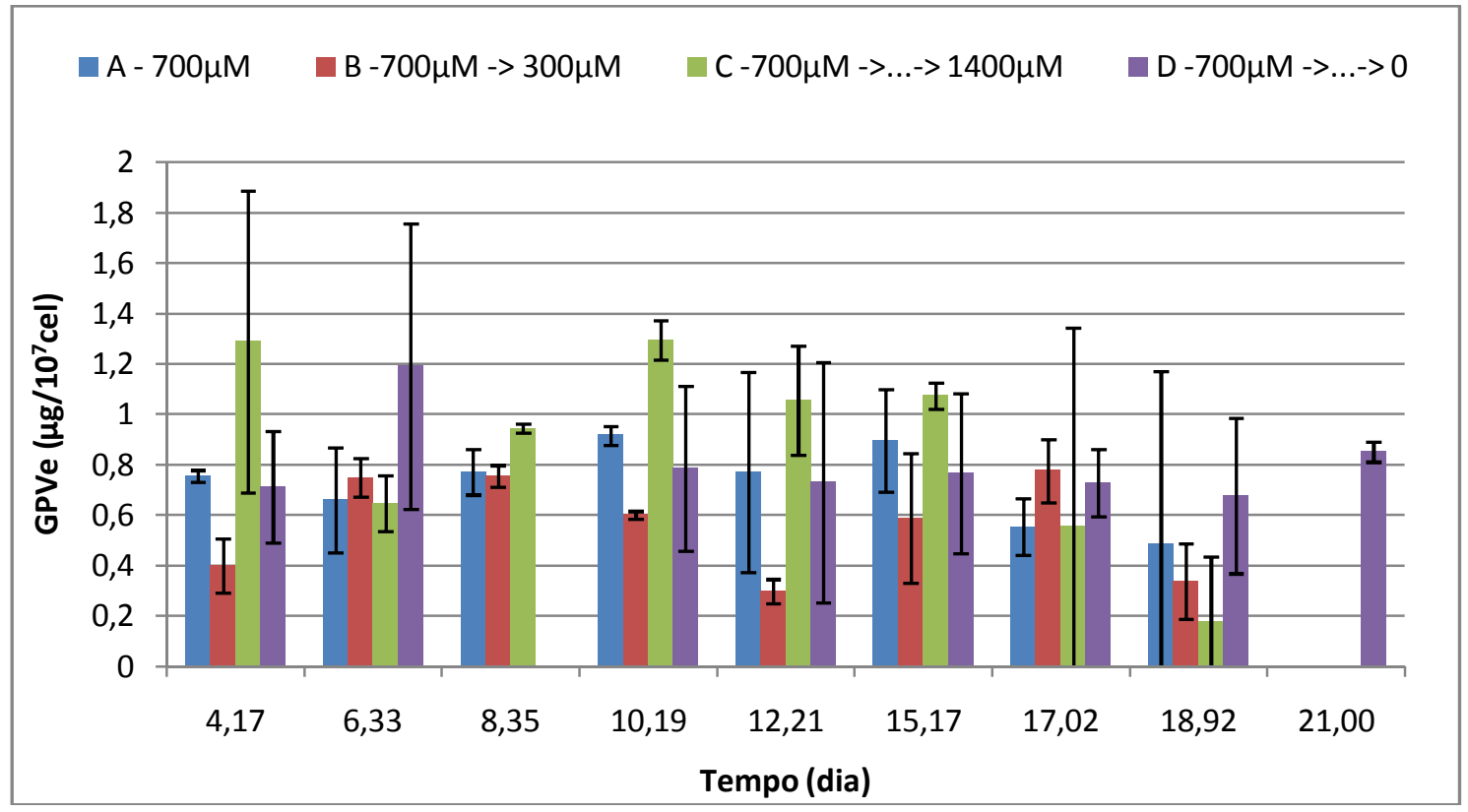

Gráfico 18: Produção específica de crescimento ao longo do tempo nos experimentos em schott.

O procedimento de diluições sucessivas realizado nos ensaios em schott objetivou simular o processo contínuo, porém sem controle da velocidade específica de crescimento, a qual torna-se constante quando o estado estacionário é atingido.

Os resultados indicam que a expressão por célula continuaria a mesma. Porém, a velocidade específica não se manteve constante ao longo do tempo. Uma vez que no processo contínuo a taxa de diluição é imposta e fixa, seria possível ocorrer uma lavagem no reator ao longo de tempo.

Com base neste conjunto de ensaios pode-se afirmar que as células S2MtGPV não são recomendadas para processos contínuos com um único reator, pois o indutor é nocivo ao crescimento celular. Porém, hipoteticamente seria possível a realização de um experimento contínuo com tais células de forma viável, desde que efetuando-se o experimento com um sistema de dois reatores contínuos conectados em série, semelhante ao realizado por Pijlman et al. (2004) (vide item 3.4.3). Isto significa que, no primeiro reator as células poderiam crescer sem a presença do indutor e por fim, no segundo reator estas células seriam induzidas.

Esses resultados reforçam a escolha da linhagem celular a ser utilizada nos cultivos em processo contínuo. Ou seja, optou-se pelo desenvolvimento do processo contínuo com a linhagem celular constitutiva, S2AcGPV. 


\subsection{ENSAIO CONTÍNUO 1}

O ensaio denominado Contínuo 1 foi realizado em processo contínuo com o intuito de verificar o comportamento da célula sob diferentes velocidades específicas de crescimento. Esta velocidade é numericamente igual à vazão específica de alimentação no estado estacionário quando não há reciclo de células $\left(\mu_{x}=D\right)$. Baseado nos resultados obtidos nos ensaios com o sulfato de cobre, a linhagem celular utilizada no processo contínuo foi a S2AcGPV.

Através do cultivo é possível avaliar diferentes variáveis, tais como: concentração celular, consumo de substrato, formação de metabólitos, concentração de GPV, dentre outros.

Ao longo de todo o cultivo, a aeração foi fixada em $120 \mathrm{~mL} / \mathrm{min}$ e realizada por borbulhamento de $\operatorname{Ar}$ e $\mathrm{N}_{2}$ até o quarto dia. Após este período a aeração passou a ser feita com $\mathrm{N}_{2}$ e $\mathrm{O}_{2}$.

A concentração de oxigênio dissolvido foi controlada em 30\% de saturação. A frequência de agitação foi controlada em $90 \mathrm{rpm}$ com a temperatura mantida em $28^{\circ} \mathrm{C}$. O inóculo inicial foi de $4,08 \times 10^{5} \mathrm{cel} / \mathrm{mL}$.

O processo se iniciou de forma descontínua. Quando a concentração celular atingiu $24,5 \times 10^{6} \mathrm{cel} / \mathrm{mL}$, com aproximadamente 4 dias de cultivo, as bombas de alimentação e de retirada foram acionadas e o processo contínuo foi iniciado.

Durante esta primeira fase (processo descontínuo), pode-se calcular a velocidade específica máxima de crescimento $\left(\mu_{x, \text { máx }}\right)$ da célula utilizada, que foi de 1,2 dia $^{-1}$ (Gráfico 19). Ou seja, 20\% menor que o valor obtido na Batelada 2 (1,5 dia$\left.{ }^{1}\right)$. Este parâmetro foi importante para determinar as vazões específicas de alimentação sem que ocorra uma lavagem do reator $\left(D<\mu_{x, \text { máx }}\right)$. O Gráfico 19 mostra o cálculo de $\mu_{x, \text { máx, }}$ representado pelo coeficiente angular da reta. 

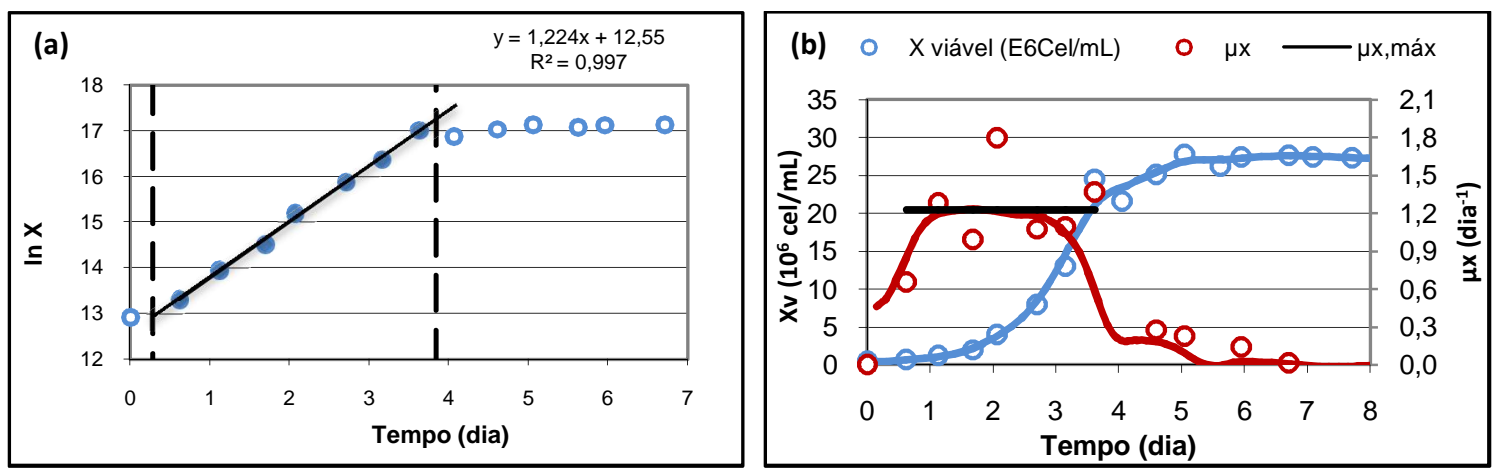

Gráfico 19: (a) Determinação de $\varepsilon_{\text {máx }}$ e (b) Curva de $\varepsilon_{x}$ ao longo do tempo no Contínuo 1.

No Gráfico 20, podem-se observar as principais variáveis de cultivo deste ensaio, tais como, pH, oxigênio dissolvido (OD) e a concentração celular ao longo dos 46 dias de cultivo. As três linhas verticais tracejadas representam o momento em que foram alteradas as vazões específicas de alimentação. A temperatura e a freqüência de agitação se mantiveram constantes ao longo do cultivo.

$\mathrm{O} \mathrm{pH}$ não foi controlado, porém foram realizadas medições através de eletrodo externo em amostras retiradas 2 ou 1 vez ao dia e não se observou grande variação ao longo do cultivo, permanecendo o mesmo em uma faixa de aproximadamente 6,5.

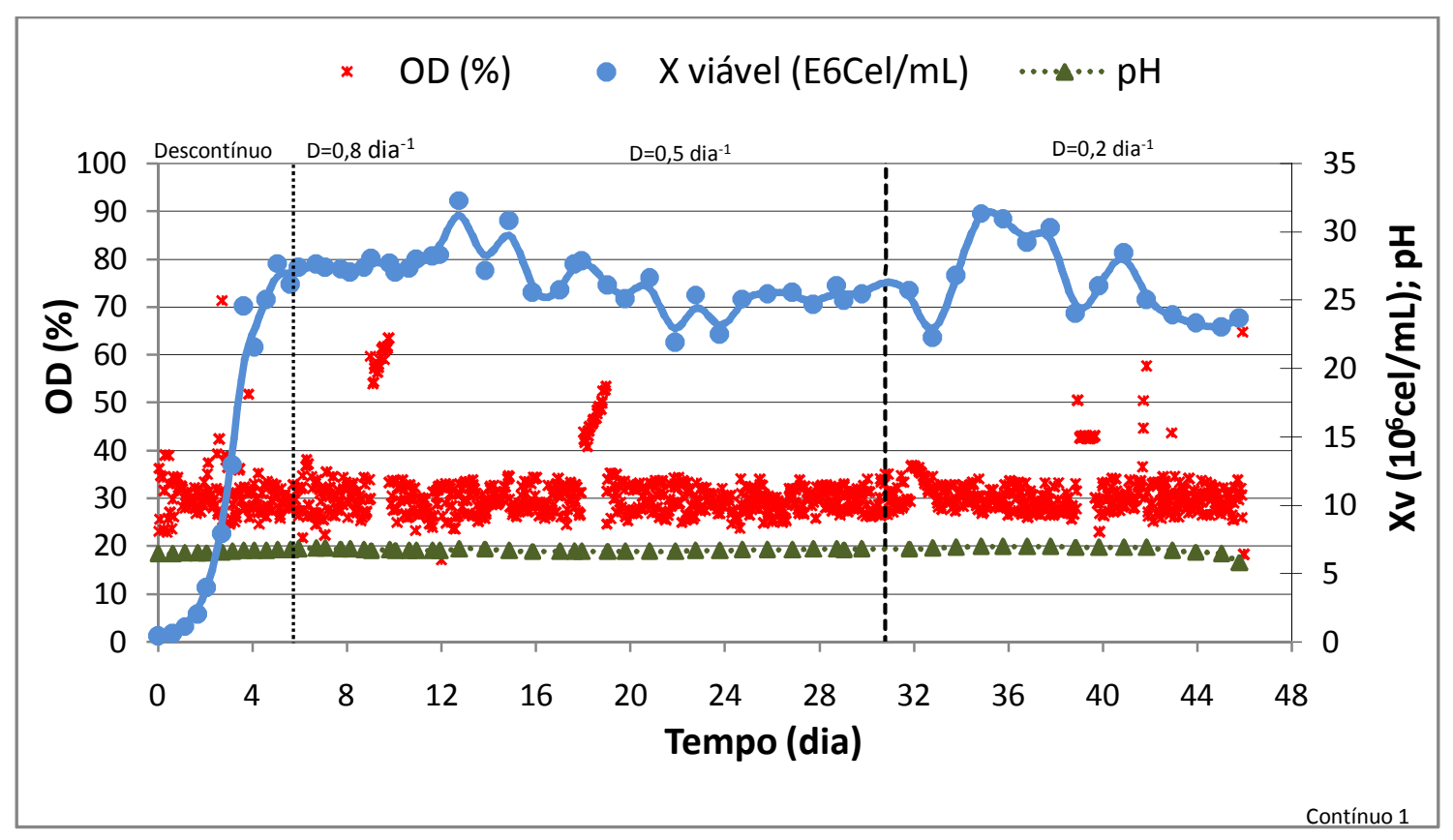

Gráfico 20: OD, pH e a Concentração de células viáveis do Contínuo 1 ao longo do tempo. 
O processo contínuo foi iniciado a uma vazão de aproximadamente $16,7 \mathrm{~mL} / \mathrm{h}, 400 \mathrm{~mL} / \mathrm{dia}$, o qual, em um volume de trabalho de $500 \mathrm{~mL}$, corresponde a $\mathrm{D}=0,8 \mathrm{dia}^{-1}$. Essa condição durou aproximadamente 6 tempos de residência e foi considerada como tendo alcançado um estado estacionário $\left(\mathrm{cv}_{\mathrm{x}}=1 \%, \mathrm{cv}_{\mathrm{glicose}}=3 \% \mathrm{e}\right.$ $\left.\mathrm{CV}_{\text {glutamina }}=4 \%\right)$. A concentração celular média atingida nesse estado foi de $27,7 \mathrm{x}$ $10^{6} \mathrm{cel} / \mathrm{mL}$.

Após estabelecida esta vazão específica, alterou-se a vazão de alimentação para $10,2 \mathrm{~mL} / \mathrm{h}, 245 \mathrm{~mL} / \mathrm{dia}$, representando um $\mathrm{D}=0,5 \mathrm{dia}^{-1}$. Devido a algumas perturbações no sistema, inclusive o rompimento da tubulação de saída, o estado estacionário foi alcançado com aproximadamente 9 tempos de residência $\left(\mathrm{cv}_{\mathrm{x}}=2 \%\right.$, $\mathrm{CV}_{\text {glicose }}=4 \%$ e $\mathrm{cv}_{\text {glutamina }}=3 \%$ ). A concentração celular média foi igual a $25,3 \times$ $10^{6} \mathrm{cel} / \mathrm{mL}$.

Por último, a vazão específica foi alterada para $0,2 \mathrm{dia}^{-1}$, ou seja, para uma vazão de $4,5 \mathrm{~mL} / \mathrm{h}, 100 \mathrm{~mL} /$ dia. Os valores médios de concentração celular obtidos foram de $26,2 \times 10^{6} \mathrm{cel} / \mathrm{mL}$. Também neste período houve algumas perturbações no sistema e o estado estacionário foi prejudicado, elevando o valor do coeficiente de variação $\left(\mathrm{cv}_{\mathrm{x}}=10 \%, \mathrm{Cv}_{\text {glicose }}=9 \%\right.$ e $\left.\mathrm{cv}_{\text {glutamina }}=7 \%\right)$. Esta condição poderia ser prolongada por mais tempo, até mesmo para garantir o estado estacionário alcançado. Porém o ensaio terminou no $46^{\text {a }}$ dia com uma contaminação no reator identificada como fungo.

A concentração celular total e a viabilidade ao longo do tempo podem ser observadas no Gráfico 21. A maior concentração celular atingida foi com o $\mathrm{D}=0,8 \mathrm{dia}^{-1}$. Com as taxas de alimentação iguais a $0,5 \mathrm{dia}^{-1}$ e $0,2 \mathrm{dia}^{-1}$, as médias das concentrações celulares no estado estacionário foram bem próximas, iguais a $25,3 \times 10^{6} \mathrm{cel} / \mathrm{mL}$ e $26,2 \times 10^{6} \mathrm{cel} / \mathrm{mL}$, respectivamente. A viabilidade celular manteve-se alta ao longo do cultivo. 


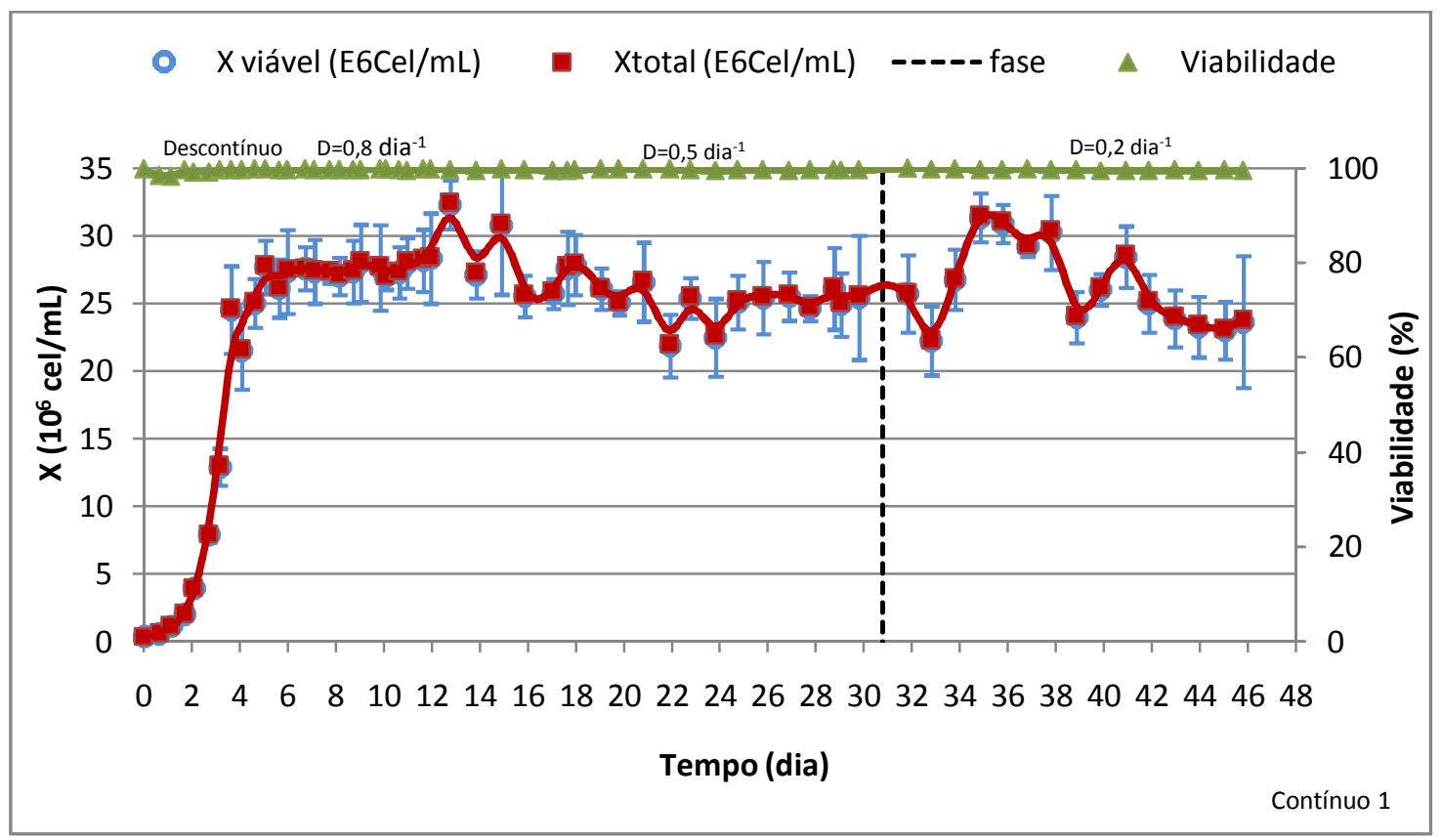

Gráfico 21: Concentração Celular e Viabilidade ao longo do Contínuo 1.

As concentrações de glicose e lactato do cultivo dosadas no HPLC são mostradas no Gráfico 22. Pode-se notar que a maior variabilidade ocorre quando a taxa de diluição de $0,2 \mathrm{dia}^{-1}$, fato demonstrado estatisticamente pelo coeficiente de variação.

Nas diferentes vazões específicas testadas, a concentração de glicose residual no meio no estado estacionário foi superior a aproximadamente $40 \%$ da concentração no meio alimentado. O valor mais baixo encontrado foi de $4 \mathrm{~g} / \mathrm{L}$ na vazão específica de $0,2 \mathrm{dia}^{-1}$, o que permite concluir não ser ela o fator limitante do crescimento celular.

Com relação à produção de lactato, pode-se observar que a sua concentração foi aumentando com o aumento da taxa de diluição. Porém, a máxima concentração encontrada foi de 3,6 dg/L e, como mostrado anteriormente, um valor possivelmente não tóxico para as células de inseto. 


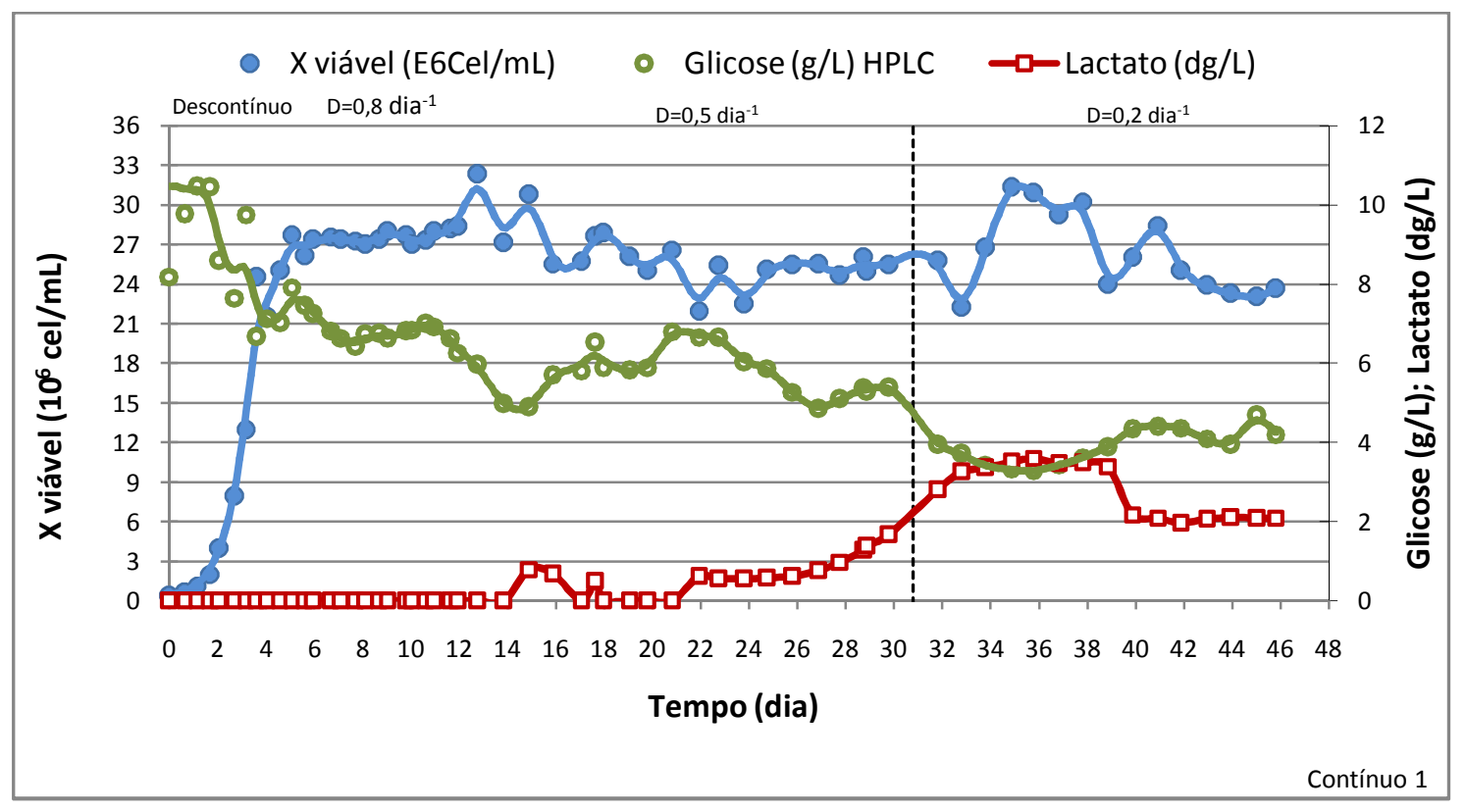

Gráfico 22: Concentrações de Glicose e Lactato ao longo do tempo.

Os perfis das concentrações residuais de glutamina e de glutamato ao longo do cultivo estão mostrados no Gráfico 23. Pode-se notar que a concentração de glutamato permaneceu praticamente constante em todo ensaio, com exceção para o período entre os $36^{\circ}$ a $40^{\circ}$ dias, no qual a concentração residual foi menor. As perturbações ocorridas neste intervalo pode ter causado um aumento no consumo de glutamato, porém este fato não é observado na concentração residual de glutamina, a qual permaneceu constante na taxa de diluição de 0,2 dia $^{-1}$.

A quantificação da concentração de amônio foi realizada em três amostras de cada estado estacionário. No primeiro estado estacionário $\left(D=0,8 \mathrm{dia}^{-1}\right)$ a concentração média das três amostras foi de $0,23 \mathrm{~g} / \mathrm{L}$, no segundo ( $D=0,5 \mathrm{dia}^{-1}$ ) foi igual a 0,28 $\mathrm{g} / \mathrm{L}$ e por fim, no último estado estacionário alcançado ( $\left.\mathrm{D}=0,2 \mathrm{dia}^{-1}\right)$, a concentração de amônia foi $0,35 \mathrm{~g} / \mathrm{L}$. Ou seja, a concentração de amônio foi aumentando com o aumento da vazão específica de alimentação.

As concentrações de amônio alcançadas são diferentes dos resultados em batelada em meio TC 100, no qual uma concentração de amônio variou entre 0,05 e $0,07 \mathrm{~g} / \mathrm{L}$ e foi suficiente para inibir o crescimento celular (GALESI et al., 2008; AGUIAR, 2010). Porém, em meio SF 900 II, também em batelada, foram observadas que concentrações de amônio de até $0,57 \mathrm{~g} / \mathrm{L}$ teve pouco efeito inibidor no crescimento das células (SWIECH, 2007). 
Com relação ao glutamato, a concentração residual deste aminoácido foi diminuindo a cada estado estacionário. Este fato pode estar relacionado (juntamente com a glutamina) com o aumento na concentração de amônio.

A concentração de glutamina residual para a taxa de diluição de $0,8 \mathrm{dia}^{-1} \mathrm{e}$ de $0,5 \mathrm{dia}^{-1}$ foram iguais a $0,5 \mathrm{~g} / \mathrm{L}$, seguindo de $0,4 \mathrm{~g} / \mathrm{L}$ em $0,2 \mathrm{dia}^{-1}$. Ou seja, a concentração de glutamina residual foi semelhante nas diferentes taxas de diluição. Há uma possibilidade de que esta concentração seja limitante para as células. Em função disso, testes com diferentes concentrações de glutamina foram realizados.

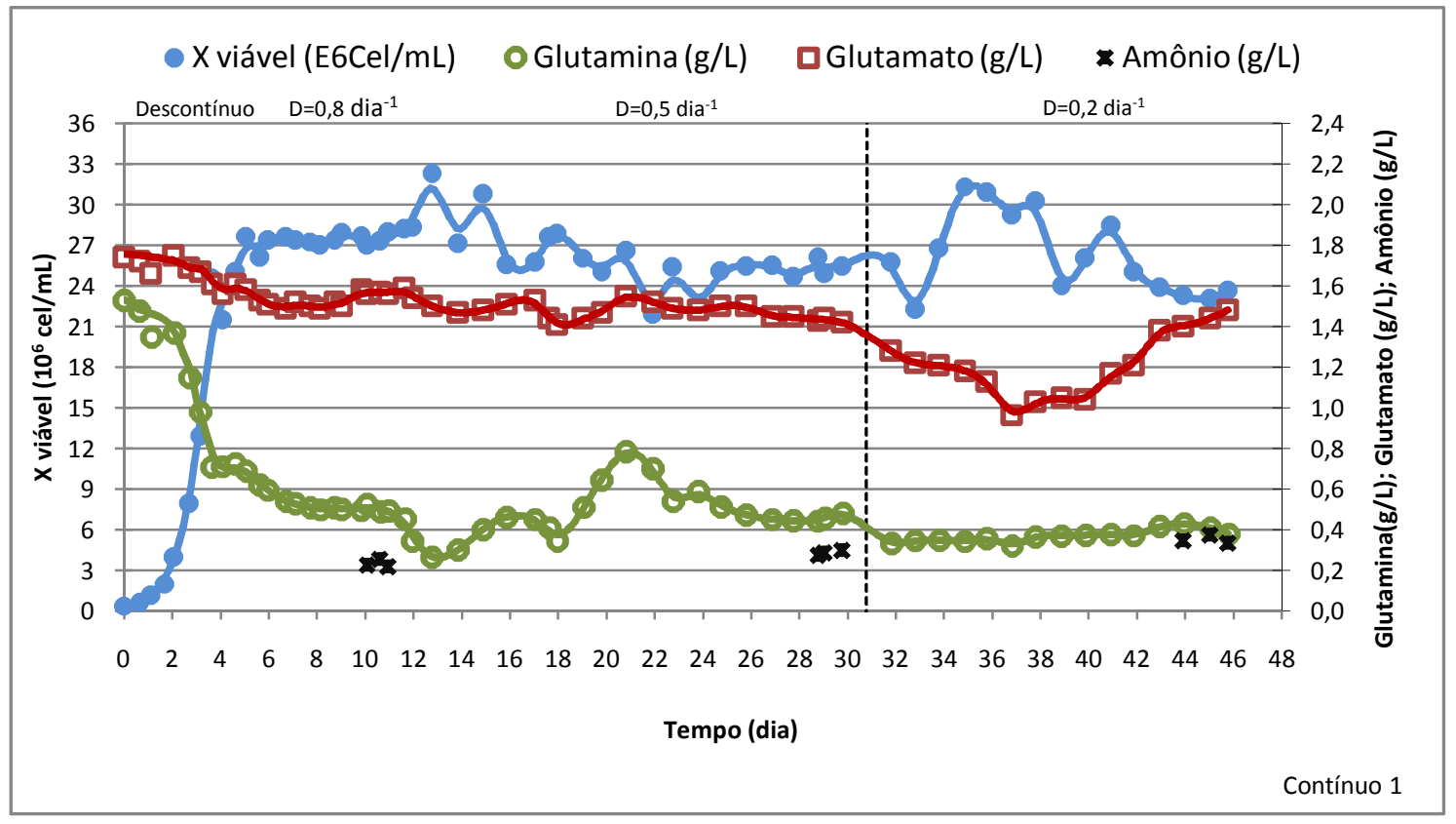

Gráfico 23: Concentração de glutamina e glutamato residual e de amônia ao longo do tempo no Contínuo 1.

A Tabela 7 mostram as variáveis de cultivo calculadas e a diferença entre elas nas três diferentes vazões específicas de alimentação.

As concentrações celulares alcançadas nos estados estacionários nas diferentes vazões específicas de alimentação $\left(0,8 \mathrm{dia}^{-1}, 0,5 \mathrm{dia}^{-1}\right.$ e de 0,2 dia $\left.{ }^{-1}\right)$ foram bem próximas. Isto se deve ao fato de que as vazões específicas de alimentação estão distantes do $\mu_{\text {máx }}$ (aproximadamente $1,2 \mathrm{dia}^{-1}$ ).

No entanto, os fatores de conversão de glicose a células foram diminuindo à medida que a vazão específica de alimentação diminuiu. Isto permite concluir que realmente a glicose não é o substrato limitante, pois o $\mathrm{Yx} / \mathrm{s}_{\text {limitante, }}$ teoricamente, seria 
constante ao longo do cultivo. Os altos valores de glicose residual obtidos também levam a crer que não foi o substrato limitante.

Tabela 7: Variáveis calculadas para diferentes vazões específicas de alimentação no estado estacionário para o cultivo Contínuo 1.

\begin{tabular}{|c|c|c|c|}
\hline \multirow{2}{*}{ Variáveis } & \multicolumn{3}{|c|}{$\mathrm{D}\left(\mathrm{dia}^{-1}\right)$} \\
\hline & 0,8 & 0,5 & 0,2 \\
\hline $\mathrm{Xv}\left(10^{6} \mathrm{cel} / \mathrm{mL}\right)$ & 27,7 & 25,3 & 26,2 \\
\hline CV (Xv) (\%) & 1 & 2 & 10 \\
\hline Glicose residual (g/L) & 6,8 & 5,2 & 4,0 \\
\hline CV (Glicose residual) (\%) & 4 & 4 & 10 \\
\hline Glutamina residual (g/L) & 0,49 & 0,46 & 0,38 \\
\hline CV (Glutamina residual) (\%) & 4 & 3 & 7 \\
\hline Amônio (g/L) & 0,23 & 0,28 & 0,35 \\
\hline CV (amônio) (\%) & 7 & 3 & 5 \\
\hline $\mathrm{Y}_{\mathrm{X} / \mathrm{GLC}}$ (célula/g de glicose) & $7,5 E+09$ & $4,8 \mathrm{E}+09$ & $4,0 E+09$ \\
\hline$Y_{X / G L N}$ (célula/g de glutamina) & $2,7 \mathrm{E}+10$ & $2,4 \mathrm{E}+10$ & $2,3 \mathrm{E}+10$ \\
\hline $\mathrm{Y}_{\mathrm{ALA} / \mathrm{GLN}}$ (g de alanina/g de glutamina) & 0,18 & 0,23 & 0,27 \\
\hline $\mathrm{Y}_{\mathrm{NH} 4 / \mathrm{GLN}}$ (g de $\mathrm{NH}_{4} / \mathrm{g}$ de glutamina) & 1,51 & 1,86 & 1,73 \\
\hline Teor de GPV $\left(\mu \mathrm{g} / 10^{7}\right.$ cel) & 0,21 & 0,11 & 0,08 \\
\hline Concentração de GPV ( $\mu \mathrm{g} / \mathrm{L})$ & 579 & 267 & 206 \\
\hline Produtividade ( $\mu \mathrm{g} / \mathrm{L} . \mathrm{h})$ & 19,3 & 5,6 & 1,7 \\
\hline
\end{tabular}

Com relação à glutamina, os fatores de conversão de glutamina a células também decresceram com a redução da vazão específica de alimentação. Porém esta variação não é suficiente para concluir se há limitação por glutamina, sendo necessária a realização de ensaios específicos.

Os fatores de conversão $\mathrm{Y}_{\mathrm{ALA} / \mathrm{GLN}}$ e $\mathrm{Y}_{\mathrm{NH} \text { 4/GLN }}$ indicam a produção de subprodutos (alanina e amônia) por molécula da glutamina consumida. Com isso, pode-se notar que a diminuição na taxa de diluição causa um aumento na produção de alanina.

Para o cálculo de $\mathrm{Y}_{\mathrm{NH} 4 / \mathrm{GLN}}$ foi considerada uma concentração inicial de amônio no meio SF 900 II igual a 41,7 mg/L (Swiech, 2007). O Y $_{\mathrm{NH} 4 / \mathrm{GLN}}$ variou sem 
apresentar uma tendência em relação à taxa de diluição. É interessante notar que a maior concentração de amônio observada foi no último estado estacionário. Porém, nessa mesma taxa de diluição não foi observado um maior $Y_{N H 4 / G L N}$, indicando novamente que a produção de amônia pode estar relacionada com o decréscimo de glutamato.

Com relação à concentração de GPV, houve um problema nas análises na

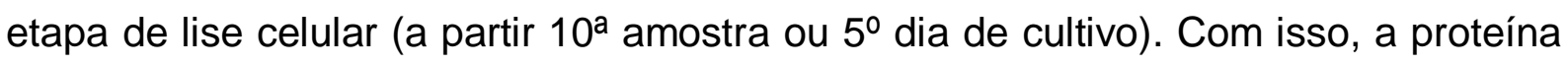
não foi totalmente extraída da célula de forma que se supõe que o valor real seja maior que o valor dosado. $\mathrm{O}$ teor de GPV ao longo do ensaio foi diminuindo com o decréscimo da taxa de diluição. O teor máximo de GPV encontrado foi à taxa de diluição de $0,8 \mathrm{dia}^{-1} \mathrm{e}$ foi de $0,21 \mu \mathrm{g} / 10^{7}$ cel.

A produtividade máxima alcançada foi de $26 \mu \mathrm{g} / \mathrm{L}$.h na taxa de diluição de $0,8 \mathrm{dia}^{-1}$. Pode-se notar que mesmo com os problemas de análise acima mencionados, a produtividade máxima alcançada foi próxima a obtida na Batelada 2 (30 $\mu \mathrm{g} / \mathrm{L}$.h). A produtividade máxima na taxa de diluição de 0,5 dia $^{-1}$ foi de $6 \mu \mathrm{g} / \mathrm{L}$.h, seguindo de $3 \mu \mathrm{g} / \mathrm{L}$.h na taxa de $0,2 \mathrm{dia}^{-1}$.

Foram realizadas dosagens de aminoácidos em três amostras, cada uma representando o estado estacionário das três diferentes vazões específicas de alimentação (Gráfico 24). Em geral, pode-se observar que a arginina, a lisina e a metionina não foram consumidas ao longo do cultivo.

Houve a formação de alanina e de fenilalanina nos três casos. Os demais aminoácidos foram consumidos em todos os estados estacionários, podendo-se destacar os que foram mais consumidos: a glutamina, asparagina, prolina, serina, leucina e cisteína. Nenhum dos aminoácidos se esgotou durante o ensaio, porém a concentração de cisteína encontrada nos estados estacionário foi a mais baixa. 


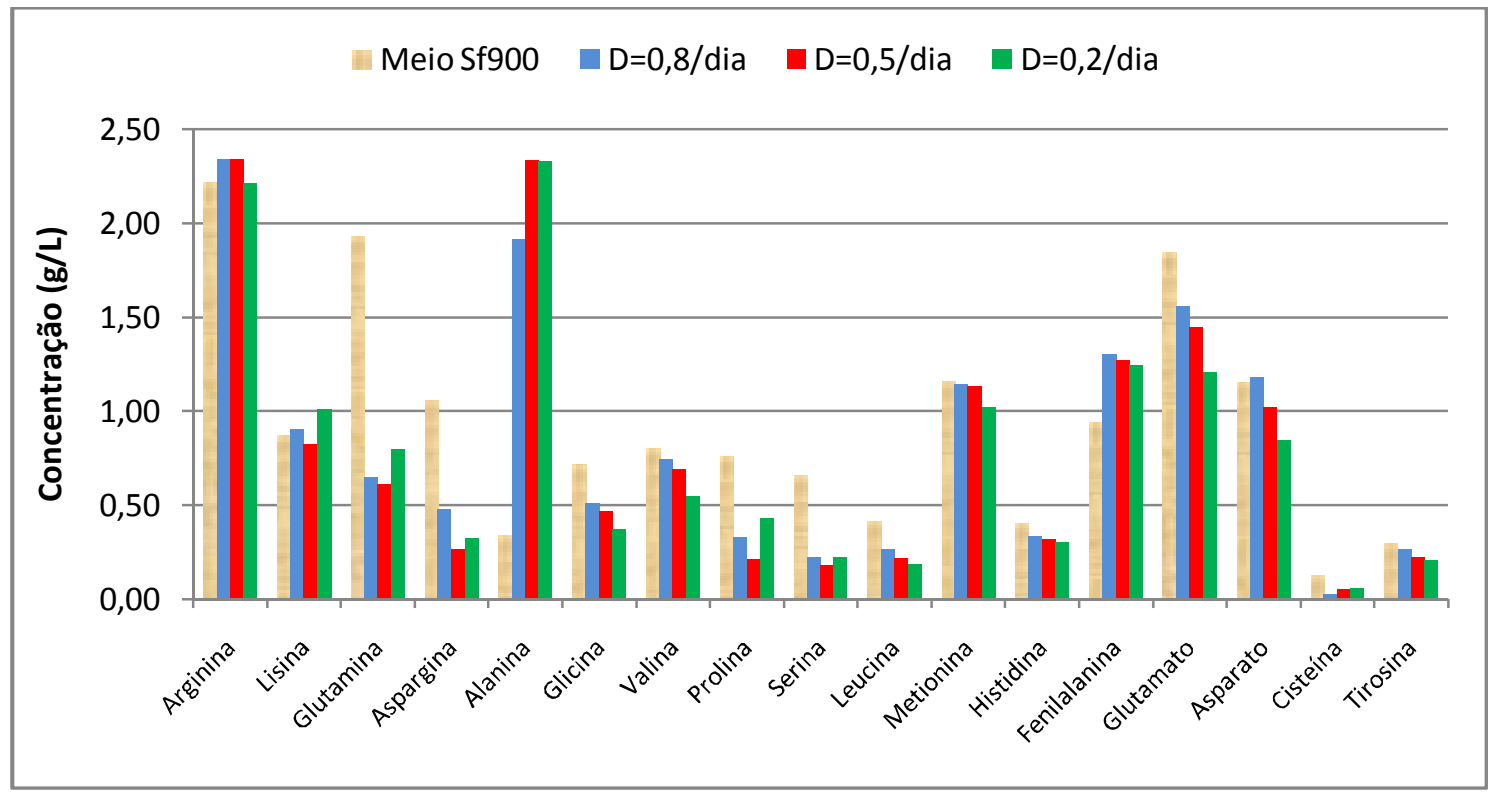

Gráfico 24: Concentração de aminoácidos nos diferentes estados estacionários alcançados no Contínuo 1 em comparação com a concentração inicial do meio SF 900 II.

\subsection{ENSAIO EM SCHOTT COM DIFERENTES CONCENTRAÇÕES DE GLUTAMINA}

Os ensaios em schott com diferentes concentrações iniciais de glutamina no meio SF 900 II foram realizados para verificar o comportamento do metabolismo celular com relação a glutamina.

Para isso, foram realizados quatro schotts com concentrações diferentes deste substrato. Variou-se a concentração de glutamina inicial com valores entre $1,7 \mathrm{~g} / \mathrm{L}$ ï o que representa a concentração do meio de cultura SF 900 II - e 4,8 g/L. O Gráfico 25 mostra as curvas de crescimento para cada schott. Cada gráfico possui duas curvas diferentes, pois os experimentos foram feitos em duplicata.

Observando o Gráfico 25, em geral, as células se comportaram de maneira semelhante com relação à curva de crescimento ao longo de tempo. Pode-se verificar também que a concentração celular máxima foi alcançada em uma das duplicatas do ensaio $B\left(32,4 \times 10^{6} \mathrm{cel} / \mathrm{mL}\right)$. Este foi justamente 0 ensaio onde a diferença entre as duplicatas foi maior. 
Em suma, apenas a análise da curva de crescimento é insuficiente para afirmar qual a concentração ideal de glutamina, uma vez que não há testes de hipóteses para comparação de curvas, mas sim para comparação de média de variáveis/ parâmetros. Por isso, a comparação entre cada condição foi realizada através de análise de variância (ANOVA - GraphPad Prism) com as médias das variáveis: $X v_{\text {máx }}, G_{P V}$,máx e $\Pi_{G P V m a ́ x}$. Para os parâmetros como $\mu_{x, \text { máx }}, Y_{X / G L C}$ EXP , $Y_{X / G L N}{ }^{E X P}$, o cálculo foi realizado baseado na regressão linear do todos os pontos das duplicata, também através do programa GraphPad Prism.
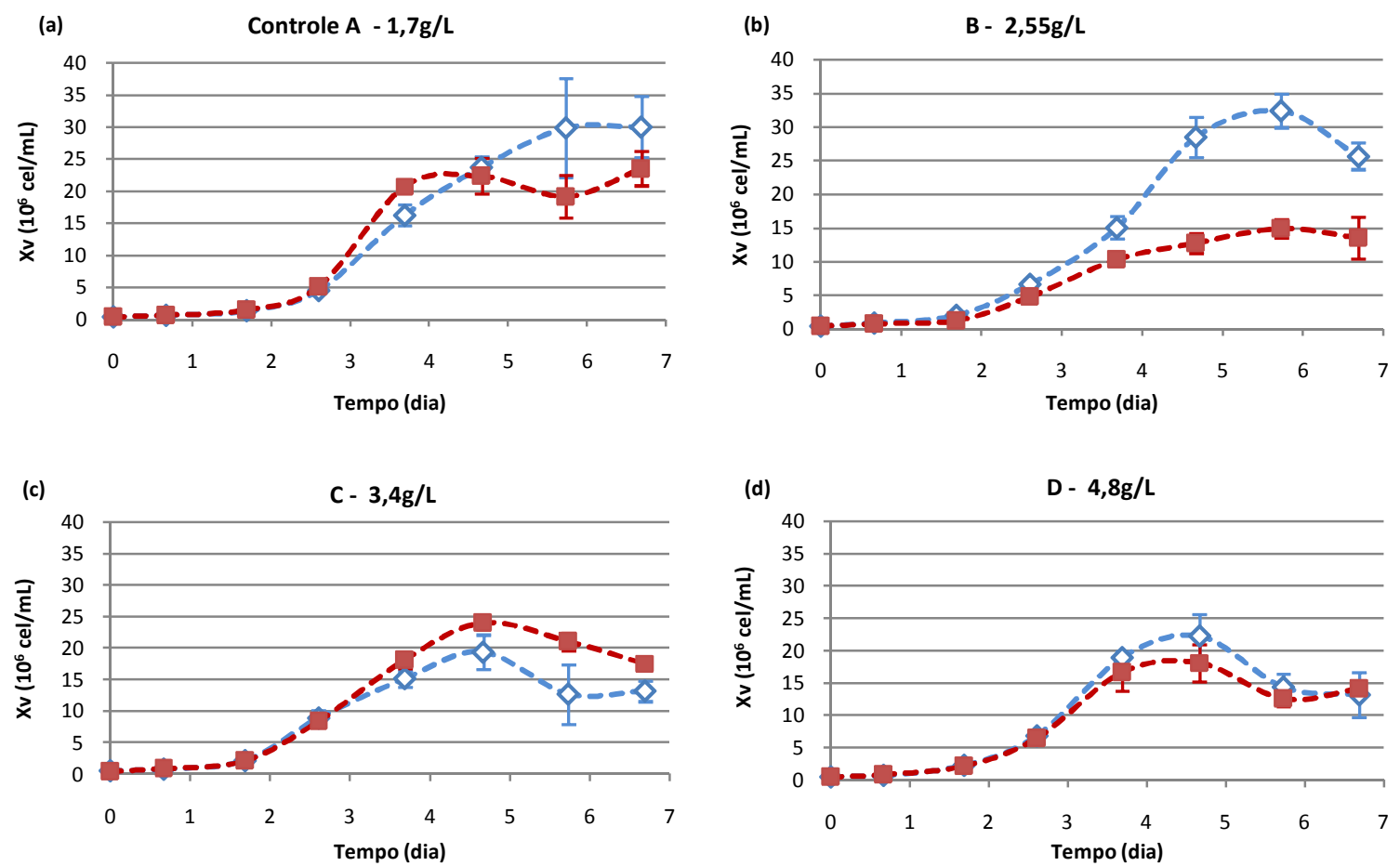

Gráfico 25: Curvas de crescimento dos ensaios em schott com diferentes concentrações iniciais de glutamina. (a) Controle A 1,7 g/L, (b) B ï 2,55 g/L, (c) C ï 3,4 g/L e (d) D ï 4,8 g/L.

Em todos os ensaios a fase exponencial de crescimento foi exatamente no mesmo período, representada por linhas verticais tracejadas nos Gráficos 26 e 27.

A concentração de lactato produzido foi baixa em todos os ensaios, não ultrapassando o valor de $0,26 \mathrm{~g} / \mathrm{L}$. O perfil da concentração de glicose ao longo do tempo para todos os ensaios foi o mesmo (Gráficos 26). Em todos os ensaios a concentração inicial de glicose foi igual a 10,6 g/L, alcançando uma concentração de $8 \mathrm{~g} / \mathrm{L}$ no fim da fase exponencial. A diferença entre os schotts está após a fase exponencial. Porém, não há esgotamento de glicose em nenhum dos testes. 
(a)
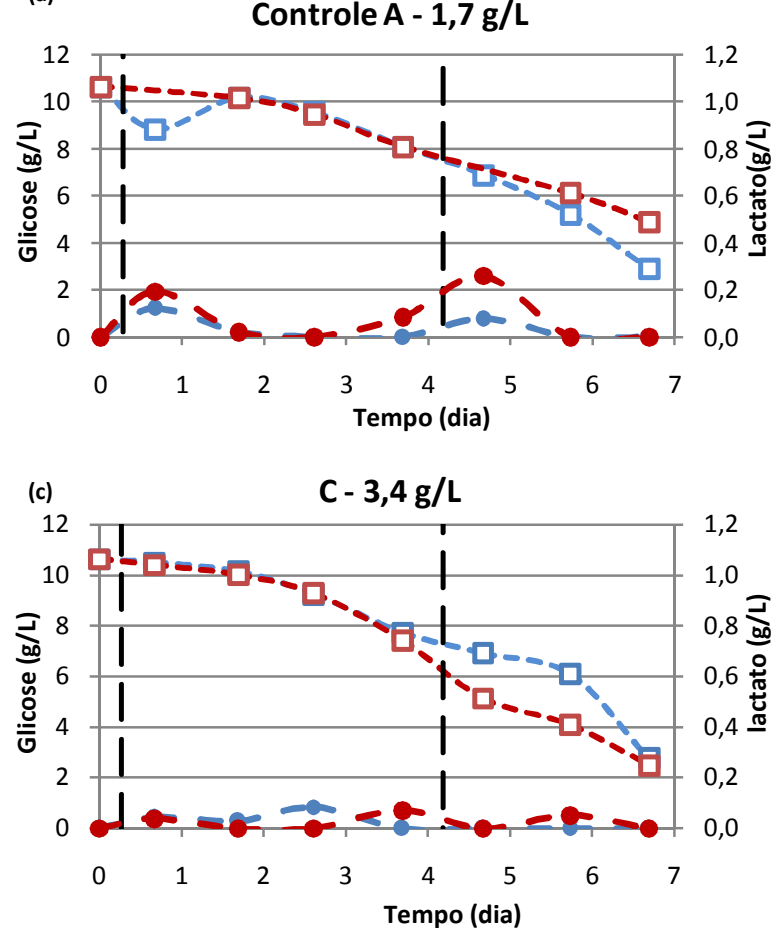

(b)
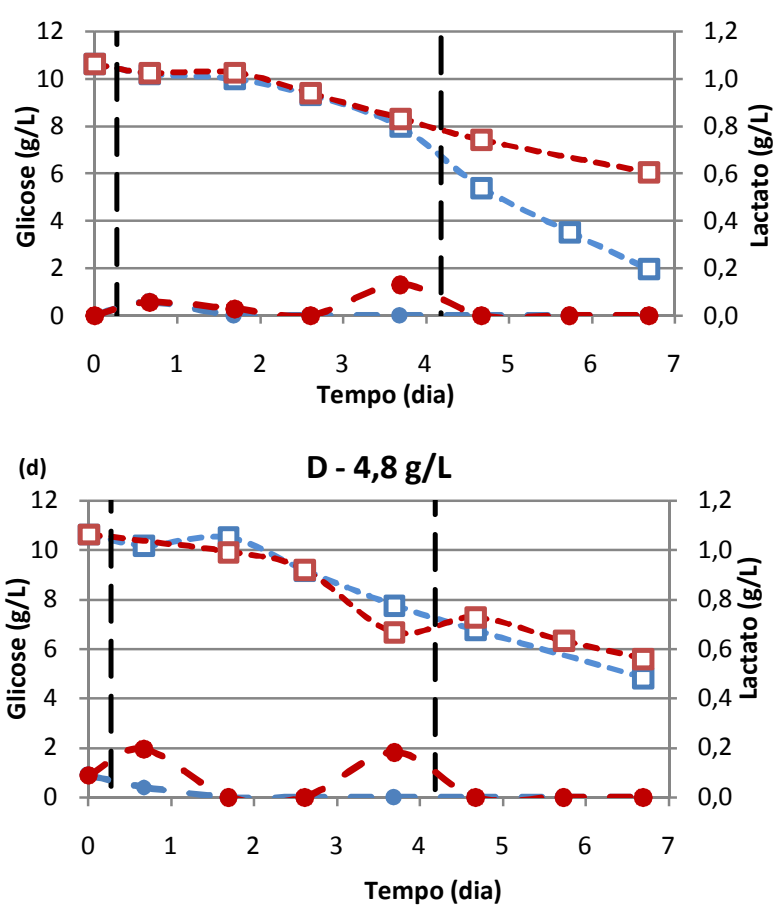

Gráfico 26: Concentração de glicose residual e formação de lactato ao longo do tempo dos ensaios em schott com diferentes concentrações inicias de glutamina. (a) Controle A $1,7 \mathrm{~g} / \mathrm{L}$, (b) B ï 2,55 g/L, (c) C ï 3,4 g/L e (d) Dï 4,8 g/L. (口) Glicose, (ǒ) Lactato.

O glutamato foi pouco consumido em todos os ensaios (Gráficos 27). Sua concentração inicial foi de $1,9 \mathrm{~g} / \mathrm{L}$ e a concentração final foi de $1,4 \mathrm{~g} / \mathrm{L}$, com exceção do ensaio com 4,8 $\mathrm{g} / \mathrm{L}$ de glutamina que consumiu menos glutamato (concentração final igual a $1,7 \mathrm{~g} / \mathrm{L}$ ). Este mesmo perfil na concentração de glutamato foi obtido no ensaio em batelada no biorreator (Batelada 2).

Com relação à concentração de glutamina, o maior consumo deste aminoácido foi observado no ensaio $D$, no qual foram consumidos $4 \mathrm{~g} / \mathrm{L}$ em 7 dias de cultivo, restando assim $0,8 \mathrm{~g} / \mathrm{L}$. No entanto, a glutamina foi praticamente toda consumida nos ensaios A, B e C em 7 dias de cultivo, restando aproximadamente $0,05 \mathrm{~g} / \mathrm{L}$ (Gráficos 27). Com esses resultados, pode-se notar que o consumo de glutamina pode não estar somente associado ao crescimento celular, pois houve um aumento no consumo e não houve mudanças significativas na concentração celular. 
(a)

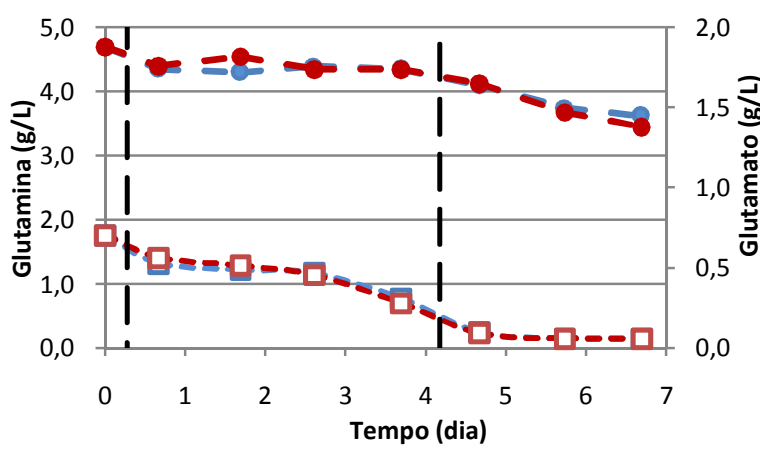

(c)

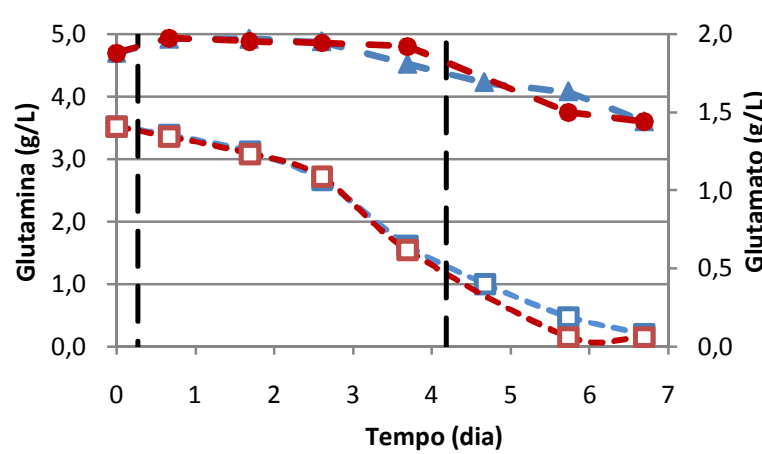

(b)

$B-2,55 \mathrm{~g} / \mathrm{L}$

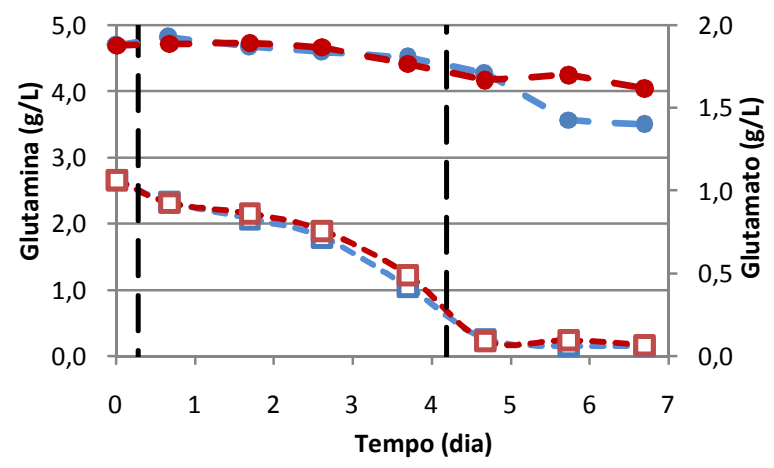

(d)

$D-4,8 \mathrm{~g} / \mathrm{L}$

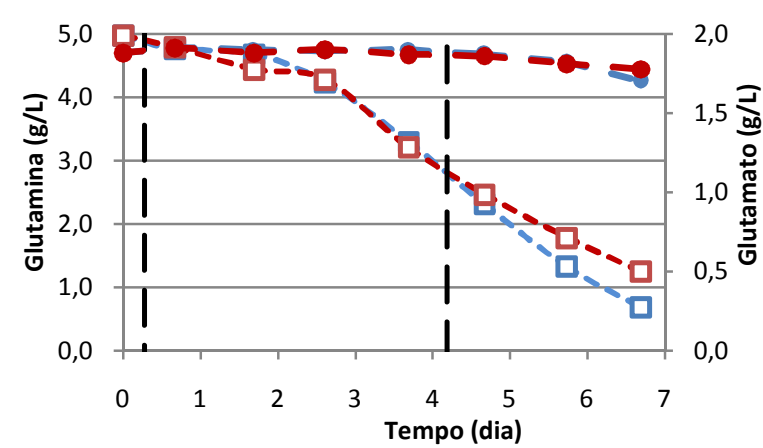

Gráfico 27: Concentração de glutamina e glutamato residual ao longo do tempo dos ensaios em schott com diferentes concentrações inicias de glutamina. (a) Controle A 1,7 g/L, (b) B ï 2,55 g/L, (c) C ï 3,4 g/L (d) D ï 4,8 g/L. (İ ) Glutamina, (ǒ) Glutamato.

Como dito anteriormente, para fins de comparação entre os ensaios, o Gráfico 28 apresenta as variáveis calculadas $X_{v \text {,máx }}{ }^{\text {EXP }}, \mu_{\text {máx }}, Y_{X / G L N}{ }^{\text {EXP }}, Y_{X / G L C}{ }^{\text {EXP }}$,

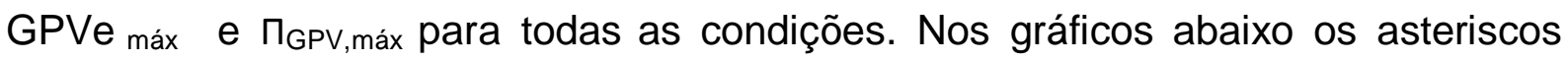
sobre as barras indicam a presença de diferenças estatísticas significativas entre as condições testadas e o ensaio controle. 
(a)

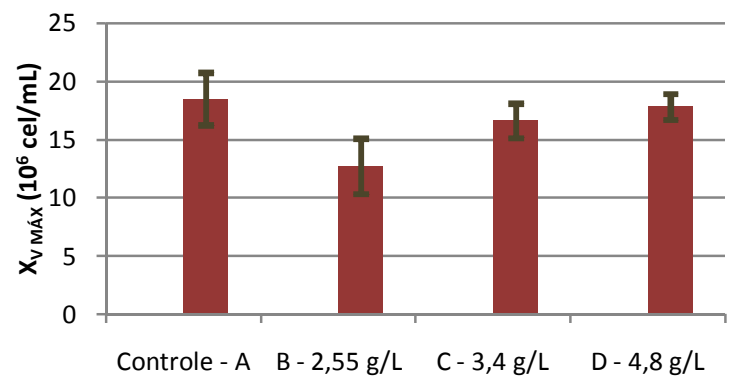

(c)

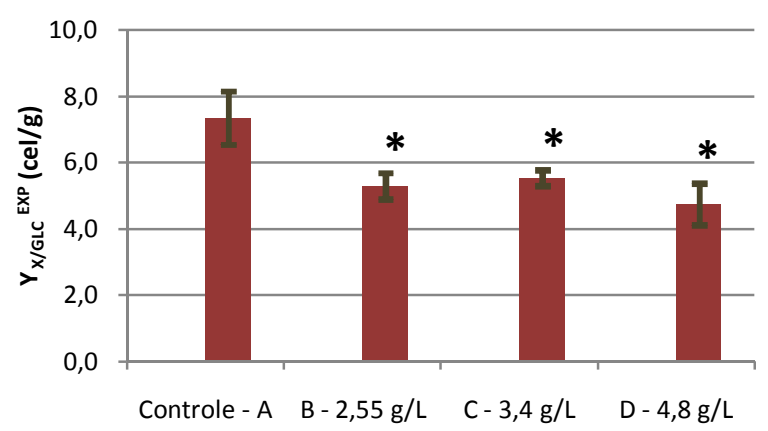

(e)

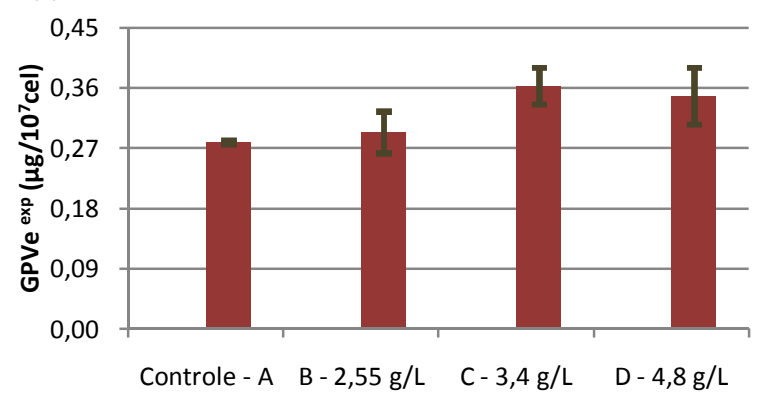

(b)

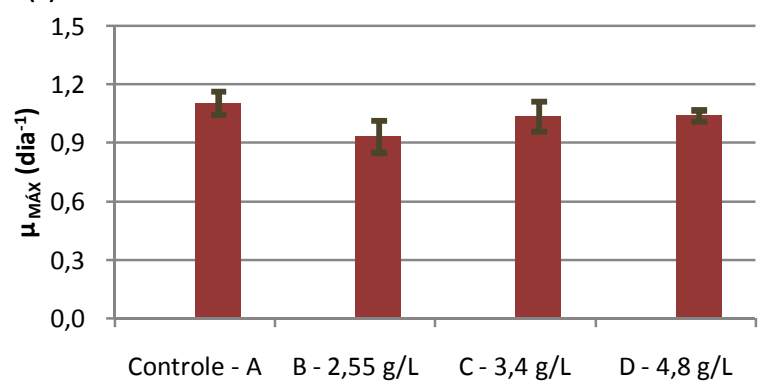

(d)

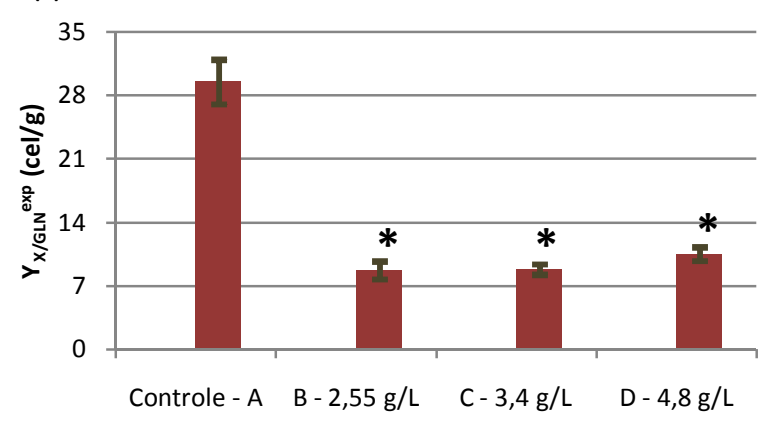

(f)

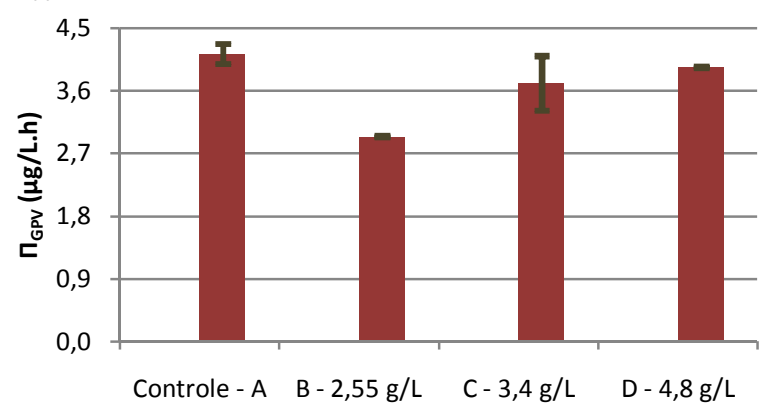

Gráfico 28: Concentração entre ensaios em schott com diferentes concentrações inicias de glutamina. (a) $X v_{\text {máx }}$, (b) $\mu_{x, \text { máx }}$ (c) $Y_{X / G L N}{ }^{E X P}$, (d) $Y_{X / G L C}{ }^{E X P}$, (e) GPVe ${ }^{\text {EXP }}$ e (f) $\forall_{G P V}$.

Pode-se observar (Gráfico 28a) que não existem diferenças significativas entre os ensaios suplementados com glutamina em relação ao $X v_{\text {máx }}$, indicando que a concentração inicial do meio SF 900 II é suficiente para o cultivo desta linhagem celular nestas condições.

Com relação à velocidade específica máxima de crescimento, também é possível afirmar que não há diferenças significativas entre as duplicatas, nem mesmo entre os ensaios. Portanto, o aumento na concentração de glutamina inicial no meio SF 900 II não altera a velocidade específica máxima de crescimento tampouco prolonga o fim da fase exponencial (Gráfico 28b). 
Aguiar (2010) realizou ensaios em biorreator com diferentes concentrações de glutamina $(0,6,1,75,3,5$ e $7 \mathrm{~g} / \mathrm{L})$ no meio TC 100 . Seus resultados permitiramIhe concluir que $\mu_{\text {máx }}$ foi menor quando a concentração de glutamina inicial foi igual a 0,6 g/L, no entanto, se manteve constante nas demais concentrações de glutamina no meio $(1,75,3,5$ e $7 \mathrm{~g} / \mathrm{L})$. Porém, com relação à concentração celular máxima alcançada, o ensaio com $3,5 \mathrm{~g} / \mathrm{L}$ de glutamina foi maior que o ensaio suplementado com $1,75 \mathrm{~g} / \mathrm{L}$, fato não observado neste trabalho em meio SF $900 \mathrm{II}$.

Com relação ao fator de conversão de glicose a células (Gráfico 28c), foi possível verificar que o $Y_{X / G L C}{ }^{\text {EXP }}$ do ensaio controle foi maior. Sendo assim, deveria ter gerado uma maior concentração celular a partir da mesma quantidade de substrato consumido (cerca de $2 \mathrm{~g} / \mathrm{L}$ ). Porém, a concentração celular alcançada na fase exponencial foi próxima em praticamente todos os ensaios. Ou seja, 18,5 $\mathrm{x}$ $10^{6} \mathrm{cel} / \mathrm{mL}$ no schott A (controle), $12,7 \times 10^{6} \mathrm{cel} / \mathrm{mL}$ no schott $\mathrm{B}, 16,6 \times 10^{6} \mathrm{cel} / \mathrm{mL}$ no schott $\mathrm{C}$ e $17,8 \times 10^{6} \mathrm{cel} / \mathrm{mL}$ no schott $\mathrm{D}$.

Com relação ao $Y_{X / G L N}{ }^{E X P}$, pode-se notar que o ensaio controle também obteve um maior valor em relação aos demais ensaios. Porém, diferentemente da glicose, a quantidade de glutamina foi diferente em cada condição (Gráfico 28d). Como a concentração celular foi praticamente constante em todos os ensaios durante a fase exponencial, um aumento na concentração de glutamina deveria diminuir o YX/GLN EXP. Todavia, nos ensaios B, C e D este valor foi praticamente constante. Estes resultados reforçam a hipótese de uma mudança no metabolismo da célula.

A adição de glutamina no meio SF 900 || não influenciou a produção específica de GPV $\left(0,32 \mu \mathrm{g} / 10^{7}\right.$ cel) (Gráfico $\left.28 \mathrm{e}\right)$, consequentemente, também não alterou sua produtividade, na qual ficou em torno de 3,7 $\mu \mathrm{g} / \mathrm{L} . \mathrm{h}$ (Gráfico 28f).

\subsection{ENSAIO CONTÍNUO 2}

O ensaio denominado Contínuo 2, foi realizado em processo contínuo com o intuito de validar o estado estacionário alcançado no experimento Contínuo $1 \mathrm{com}$ uma vazão específica de $\mathrm{D}=0,8 \mathrm{dia}^{-1}$. Fatores externos comprometeram em parte 0 andamento do ensaio. Um blecaute resultou em fortes variações no ensaio. Além 
disso, as células estavam apresentando um comportamento bastante diferente com relação à respiração e velocidade de crescimento dos demais ensaios. Até $013^{\circ}$ dia ainda não havia sido necessária a adição de $\mathrm{O}_{2}$, sendo que essa troca de gases é geralmente feita $05^{\circ}$ dia de cultivo. Por essas razões, foi decidido encerrar este ensaio após 13 dias.

\subsection{ENSAIO CONTÍNUO 3}

O ensaio denominado Contínuo 3 foi realizado em processo contínuo com os mesmos objetivos do Contínuo 2, ou seja, validar o $D=0,8$ dia $^{-1}$ do Contínuo 1 e posteriormente suplementar o meio SF 900 II na alimentação com 1,7 g/L de glutamina para se atingir um novo estado estacionário. Esta concentração representa o dobro da concentração existente no meio.

Vale lembrar que, teoricamente, o valor de $\mathrm{Y}_{\mathrm{X} / \mathrm{S}}$ do substrato limitante é constante no estado estacionário, espera-se que um aumento na concentração do substrato limitante no meio de alimentação eleve a concentração celular. Assim, a hipótese de que a glutamina é o substrato limitante será confirmada se concentração celular no estado estacionário com meio suplementado com glutamina for maior que no estado estacionário em meio SF 900 II puro, mantendo-se constante a taxa de diluição.

$$
Y_{x / s}=\frac{X_{v}}{S_{f}-S}
$$

No qual $X_{V}$ é a concentração de células viáveis (cel/mL), $S_{f}$ é a concentração de substrato no meio de alimentação e $S$ é a concentração de substrato na saída do reator.

As condições de cultivos foram as mesmas do Contínuo 1, lembrando que aeração foi fixada em $120 \mathrm{~mL} / \mathrm{min}$ e realizada por borbulhamento de $\operatorname{Ar}$ e $\mathrm{N}_{2}$ até 0 quarto dia. Após este período a aeração passou a ser feita com $\mathrm{N}_{2}$ e $\mathrm{O}_{2}$.

A concentração de oxigênio dissolvido foi controlada em $30 \%$ de saturação. A frequência de agitação foi controlada em 90 rpm. A temperatura foi mantida em $28^{\circ} \mathrm{C}$. O inóculo inicial foi de $4,45 \times 10^{5} \mathrm{cel} / \mathrm{mL}$. 
O processo contínuo foi iniciado quando a concentração celular alcançou $26,4 \times 10^{6} \mathrm{cel} / \mathrm{mL}$, com aproximadamente 5 dias de cultivo.

Durante a etapa em processo descontínuo, pode-se calcular a velocidade específica máxima de crescimento $\left(\mu_{x, m a ́ x}\right)$ da célula utilizada, que foi de $1,0 \mathrm{dia}^{-1}$, ou seja, 1,2 vezes menor que o valor obtido no Contínuo 1, que foi de 1,2 dia ${ }^{-1}$. Esta diferença pode estar associada à condição das células do inóculo. O Gráfico 29

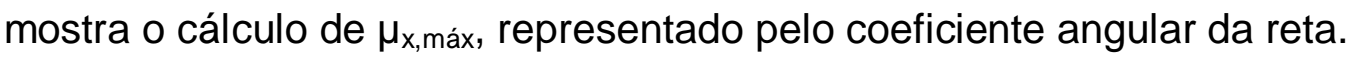
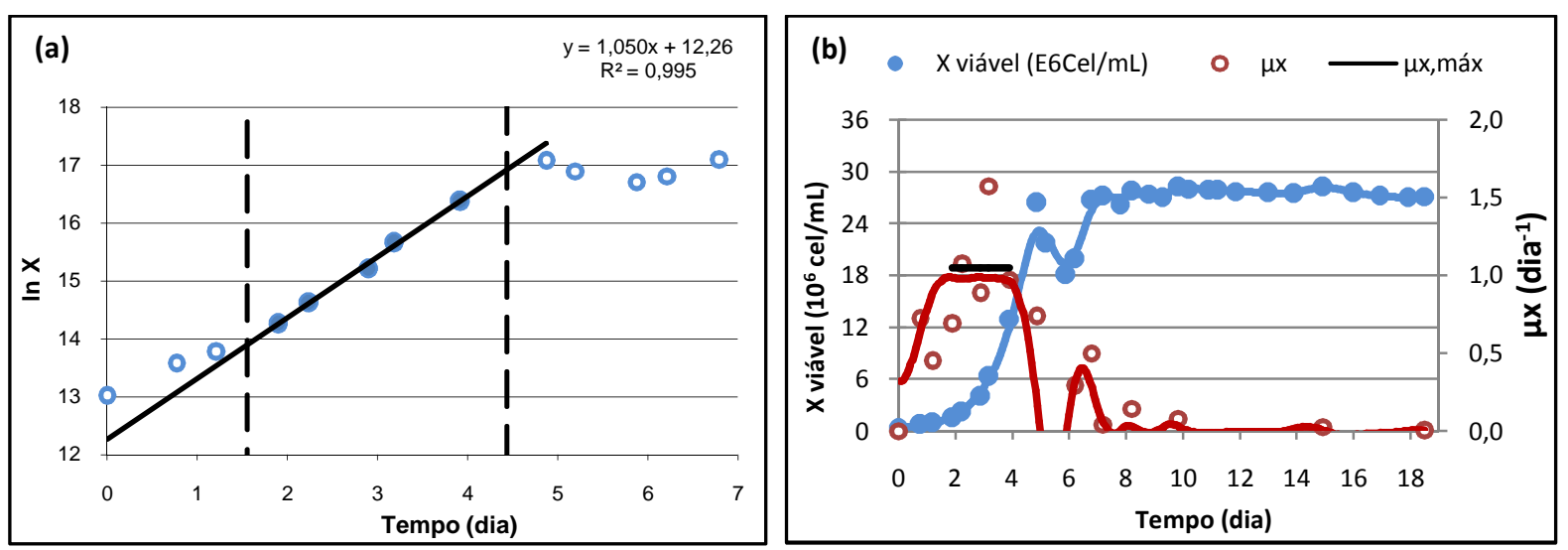

Gráfico 29: (a) Determinação de $\varepsilon_{x, \text { máx }}$ e (b) Curva de $\varepsilon_{x}$ ao longo do tempo no Contínuo 3.

O processo contínuo foi iniciado a uma vazão de aproximadamente $16,7 \mathrm{~mL} / \mathrm{h}, 400 \mathrm{~mL} /$ dia, o qual, em um volume de trabalho de $500 \mathrm{~mL}$, representa um $\mathrm{D}=0,8 \mathrm{dia}^{-1}$. Essa condição durou aproximadamente 1 dia, pois foram retiradas 2 amostras no qual a concentração de células diminuíram, fato não observado no Contínuo 1. Como a velocidade específica máxima de crescimento foi menor que no Contínuo 1, pode ser que uma vazão específica de $0,8 \mathrm{dia}^{-1}$ tenha sido muito próximo do $\mu_{x, \text { máx }}$, resultando em uma lavagem no reator. Porém, uma vez que o tempo de duração deste $D$ foi pequeno, não se pode afirmar o que ocorreu realmente. No entanto, uma nova taxa de diluição foi imposta e o teste de validação do Contínuo 1 foi com o $\mathrm{D}=0,5 \mathrm{dia}^{-1}$.

Essa condição durou 3,5 tempos de residência e foi considerado alcançado o estado estacionário, pois ao longo de 2 tempos de residência não houve alterações significativas na concentração celular, na concentração de glicose e de glutamina. A concentração celular média foi igual a $27,7 \times 10^{6} \mathrm{cel} / \mathrm{mL}(\mathrm{cv}=1 \%)$. A concentração residual de glicose foi de $5,0 \mathrm{~g} / \mathrm{L}(\mathrm{cv}=7 \%)$ e a de glutamina foi de 
$0,56 \mathrm{~g} / \mathrm{L}$ (cv=7\%). Estes valores do coeficiente de variação poderiam ter sido menores se as análises destes substratos fossem realizadas ao longo do ensaio.

Após ter alcançado o estado estacionário, outra condição foi imposta ao ensaio. A vazão específica de alimentação se manteve constante, porém o meio de alimentação foi suplementado com glutamina. Essa condição durou aproximadamente 3 tempos de residência e ao longo de todo esse tempo não houve mudanças significativas na concentração celular em relação a condição anterior, indicando que a glutamina (somente) não é o substrato que limita o processo. A concentração celular alcançada foi de $27,4 \times 10^{6} \mathrm{cel} / \mathrm{mL}(\mathrm{cv}=1 \%)$, a concentração residual de glicose e glutamina foram respectivamente de 4,7 g/L e 1,13 g/L $\left(\mathrm{Cv}_{\text {glicose }}=1 \%, \mathrm{Cv}_{\text {glutamina }}=3 \%\right)$.

O Gráfico 30 mostra as principais variáveis ao longo do cultivo. O ensaio durou 19 dias por causa de uma contaminação aparentemente por fungo. Como não houve alterações na temperatura e na velocidade de agitação, ambas não estão representadas no gráfico.

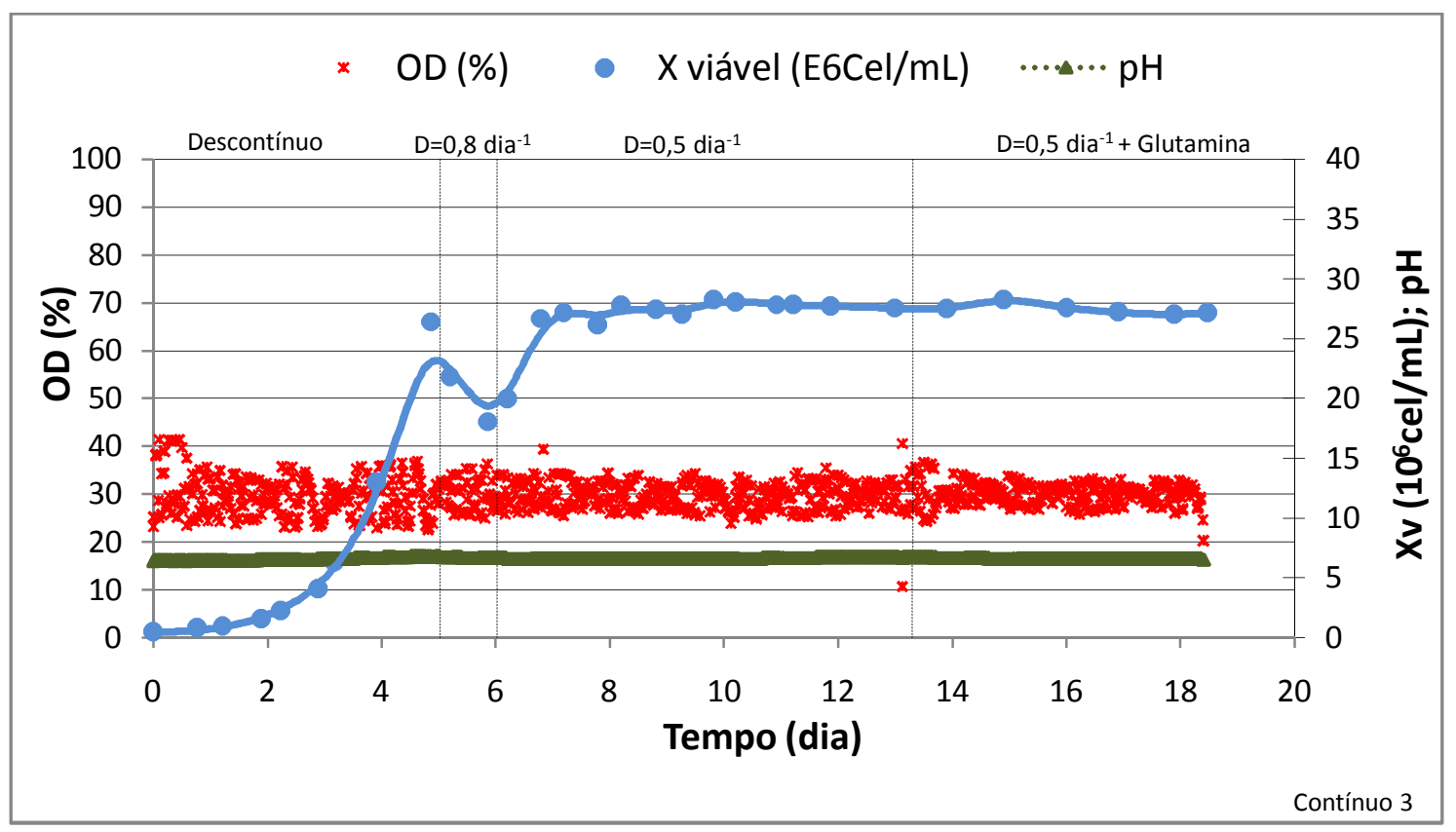

Gráfico 30: OD, pH e a Concentração de células viáveis do Contínuo 3 ao longo do tempo.

A concentração celular total e a viabilidade ao longo do tempo podem ser observadas no Gráfico 31. A viabilidade celular manteve-se alta ao longo do cultivo. 


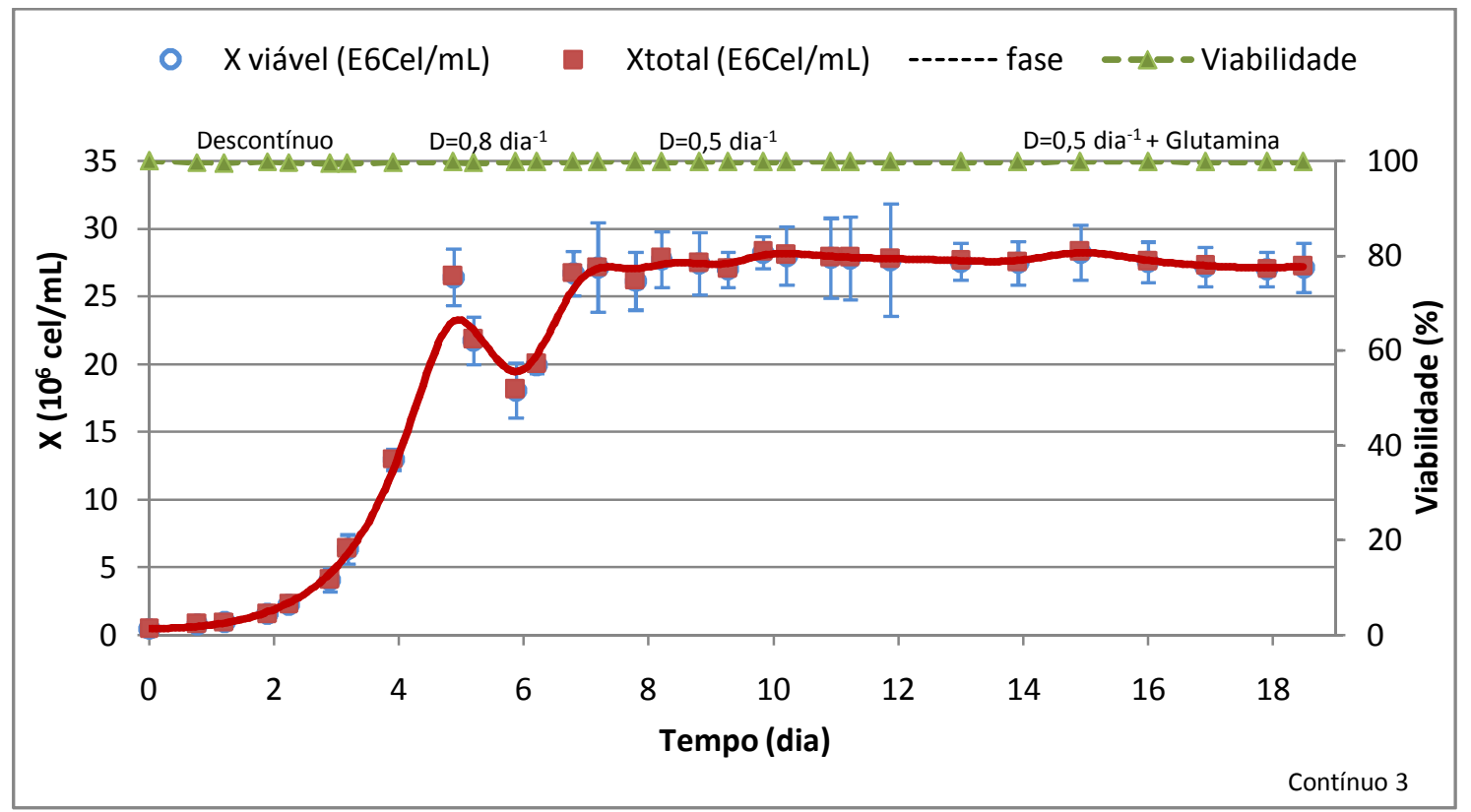

Gráfico 31: Concentração celular e viabilidade ao longo do Contínuo 3.

A concentração de lactato ao longo do cultivo não ultrapassou $0,02 \mathrm{~g} / \mathrm{L}$, com exceção do último dia que foi igual a $0,021 \mathrm{~g} / \mathrm{L}$ (mostrado no Gráfico $32 \mathrm{em} \mathrm{dg/L).}$

Com relação à glicose residual, pode-se que notar que a concentração de glicose permanece constante após a adição de glutamina ao meio de alimentação (Gráfico 32).

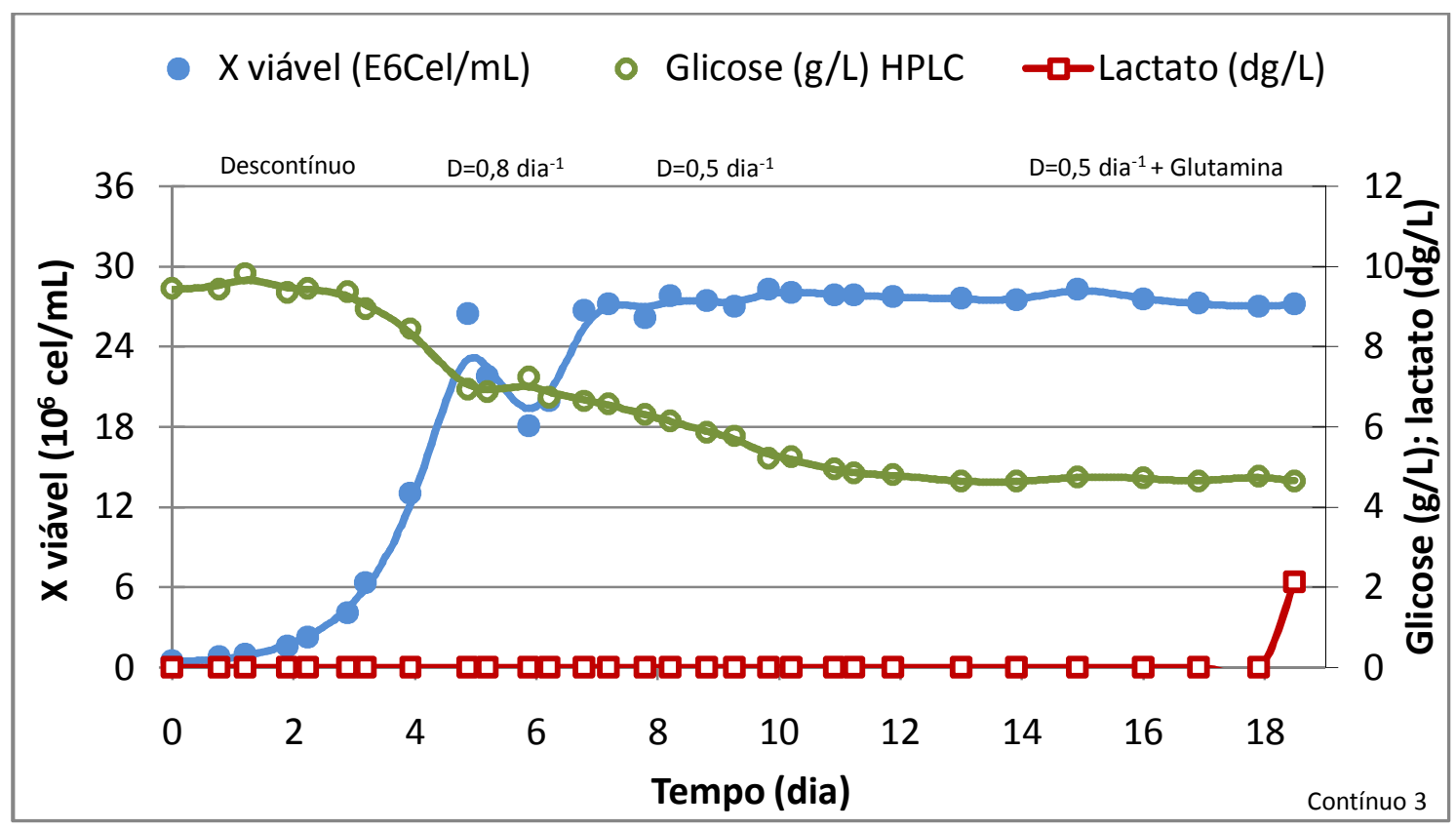

Gráfico 32: Concentração de glicose residual e de Lactato ao longo do tempo no Contínuo 3. 
A concentração de glutamato foi constante ao longo do cultivo (Gráfico 33). No entanto, com relação à glutamina, também no Gráfico 33, pode-se observar um fato interessante. A concentração do meio de alimentação foi praticamente duplicada (3,5 g/L) e a concentração de células não foi alterada, entretanto, o consumo de glutamina foi maior. Na primeira condição, o consumo de glutamina foi de 1,3 g/L e na segunda foi de aproximadamente $2,4 \mathrm{~g} / \mathrm{L}$. Este fato também foi observado nos ensaios em schott indicando mais uma vez que consumo de glutamina pode não estar somente associado ao crescimento celular. Tanto no ensaio contínuo quanto nos ensaios em schott, este fato pode ser melhor analisado comparando os $Y_{X / G L N}$, que em ambos os casos a adição de glutamina reduziu pela metade seu rendimento em células.

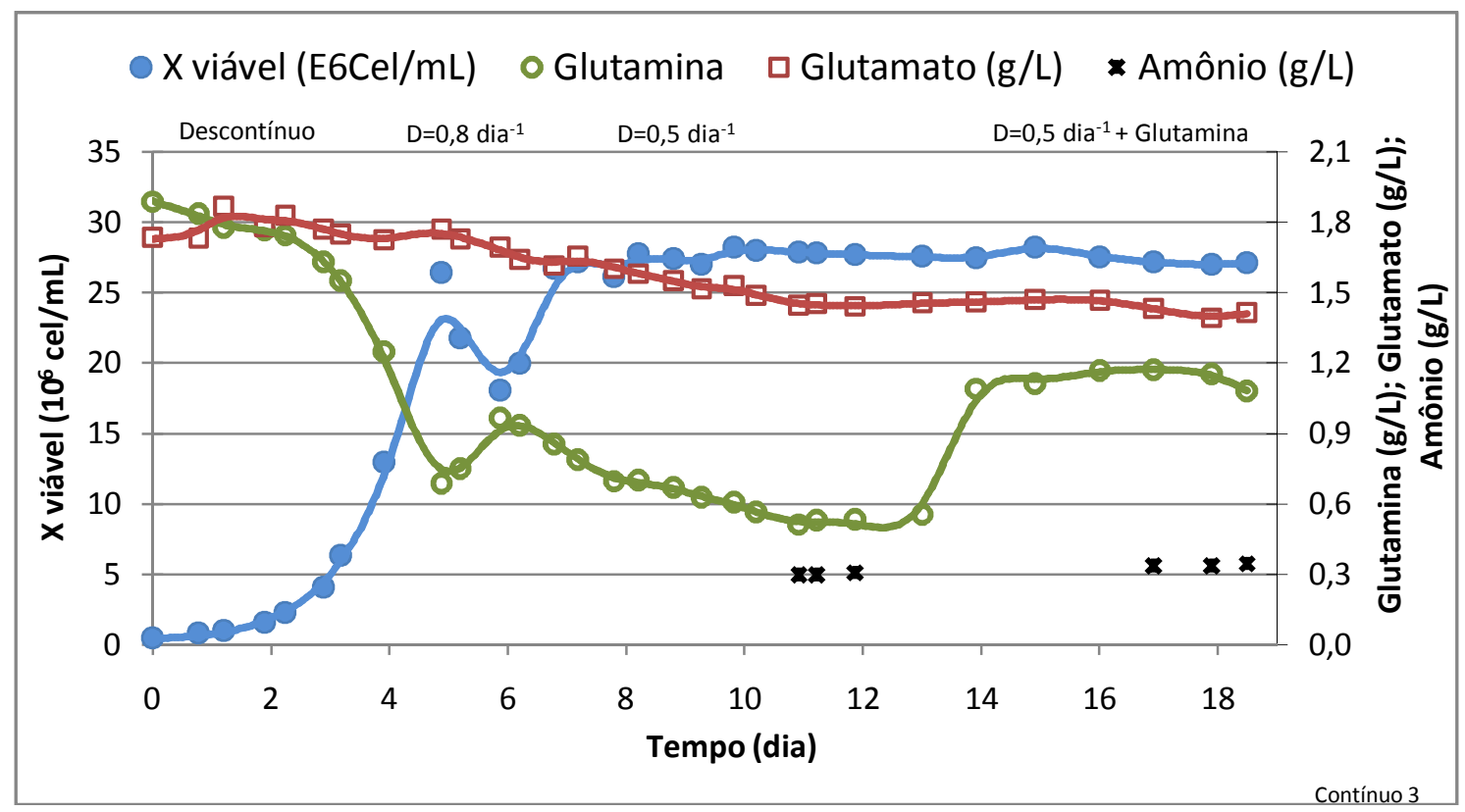

Gráfico 33: Concentrações residuais de glutamato e de glutamina ao longo do Contínuo 3.

Estudos realizados em células BHK em cultivo contínuo com adição de glutamina e em diferentes concentrações no meio de alimentação (DMEM - Meio mínimo essencial de Eagle (Dulbecco) suplementado com $5 \%$ de soro fetal bovino) resultaram em uma mudança na concentração celular (CRUZ et al., 1999). Com uma concentração de glutamina no meio de alimentação de $0,15 \mathrm{~g} / \mathrm{L}$ observou-se uma concentração celular de $0,62 \times 10^{6} \mathrm{cel} / \mathrm{mL}$. Porém, quando elevada a concentração de glutamina no meio para 0,36 g/L, a concentração celular alcançou 1,62 × $10^{6}$ $\mathrm{cel} / \mathrm{mL}$, indicando que $0,15 \mathrm{~g} / \mathrm{L}$ limitou o crescimento. No entanto, ao aumentar a 
concentração de glutamina no meio para $0,58 \mathrm{~g} / \mathrm{L}$ a concentração celular se manteve constante igual a $1,62 \times 10^{6} \mathrm{cel} / \mathrm{mL}$.

Apesar de este estudo lidar com células de mamíferos em meio de cultura diferente do utilizado neste trabalho, é possível certa analogia. Uma hipótese é a de que a concentração de glutamina inicial no meio SF 900 II seja a ideal, uma vez que a mesma não é suficiente para limitar o crescimento celular. Além disso, a adição de mais glutamina no meio de alimentação não alterou a concentração celular, fato também observado por Cruz et al. (1999).

No entanto, se a glutamina não é fonte de carbono para o crescimento celular, a célula está utilizando este aminoácido para que função?

Cruz et al. (1999) sugerem que, em células BHK sob condições de altas concentrações de glutamina $(0,08 \mathrm{~g} / \mathrm{L})$ no meio de cultura, $75 \%$ da glutamina é convertida em glutamato e o restante, principalmente, é incorporado na biomassa ou usada para a produção de outros aminoácidos. O glutamato é convertido em Ǔ cetoglutarato através de duas vias distintas.

Uma dela é através de glutamato desidrogenase e a outra é através de glutamato piruvato transaminase. Cerca de 50\% do consumo de glutamina é convertido em Ǔ-cetoglutarato através de glutamato desidrogenase e $9 \%$ por piruvato transaminase. Os dois caminhos possuem diferentes eficiências energéticas, o primeiro produz 27 moléculas de ATP por molécula de glutamina, enquanto que o segundo produz apenas 9 ATP (HÄGGSTRÖM, 1991). Esta diferença se deve principalmente ao fato de que, na via por piruvato transaminase uma molécula de piruvato é utilizado para produzir alanina, que já é normalmente secretada, o que representa uma ineficiente utilização da glutamina. No entanto, sob baixas concentrações de glutamina $(0,14 \mathrm{mM})$, a conversão para glutamato aumenta para 85\%. Nestas condições, a glutamina convertida em Ǔ-cetoglutarato é praticamente toda realizada por glutamato desidrogenase. Isso mostra uma utilização mais eficiente da glutamina para produção de energia. Assim, as células preferencialmente utilizam a via que leva à produção de mais moléculas de ATP por molécula de glutamina consumida.

Como o aumento da concentração de glutamina no meio de cultura resultou em uma maior produção de alanina (aproximadamente $12 \%$ ), é possível que sob 
estas condições o metabolismo das células S2 tenham se comportado de maneira semelhante às células BHK, porém, em concentrações de glutamina bem maiores que a utilizada em Cruz et. al (1999). A Figura 12 mostra o fluxo metabólico da glutamina em células Sf9, BHK, hibridomas (DEWS et al., 2000; CRUZ et al., 1999; HÄGGSTRÖM, 1991).

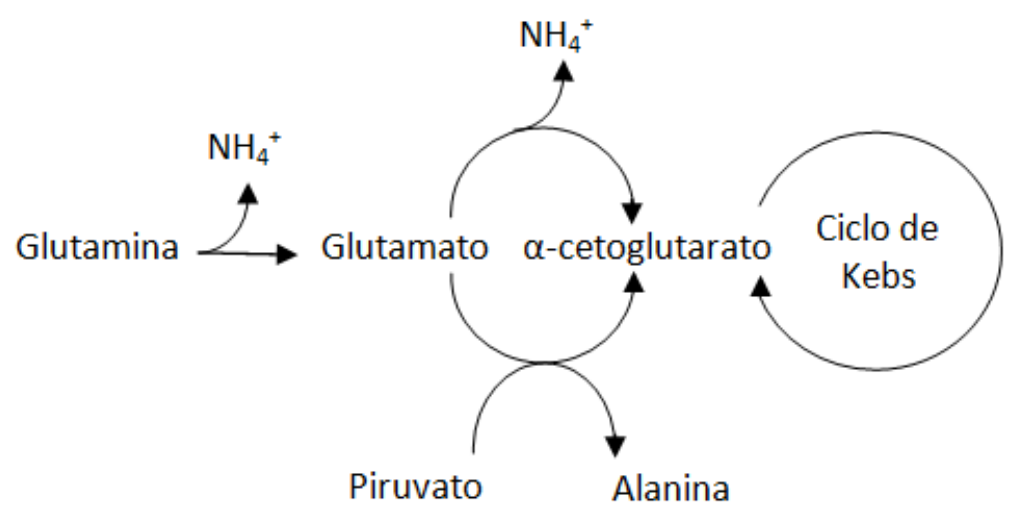

Figura 12: Fluxo metabólico da glutamina e do glutamato em células animais (DOVERSKOG et al., 1997).

A dosagem da concentração de amônia foi realizada em 3 amostras em estado estacionário. Pode-se notar (Gráfico 34) que a concentração de amônia no estado estacionário em meio SF 900 II puro foi de $0,30 \mathrm{~g} / \mathrm{L}$, enquanto que no estado estacionário após a adição de glutamina foi um pouco maior, alcançando 0,34 g/L. Este fato era esperado, como 0 consumo de glutamina aumentou consequentemente, mais amônia foi gerada.

Para melhor analise foram calculados os fatores de conversão de glutamina a alanina $\left(\mathrm{Y}_{\mathrm{ALA} / \mathrm{GLN}}\right)$ e de glutamina a amônia $\left(\mathrm{Y}_{\mathrm{NH} / \mathrm{GLN}}\right)$ nos respectivos estados estacionários. Para o cálculo de $\mathrm{Y}_{\mathrm{NH} 4 / \mathrm{GLN}}$ foi considerado uma concentração inicial de amônia no meio SF 900 II igual a 41,68 mg/L (Swiech, 2007). O Y YLA/GLN e $\mathrm{Y}_{\mathrm{NH} \text { /GLN }}$ foram praticamente duplicados após a adição de glutamina, confirmando a hipótese desta pesquisa (e similar a CRUZ et al., 1999). Estes valores são indicados na Tabela 8.

A Tabela 8 mostra as variáveis de cultivo calculadas e a diferença entre elas nas duas condições, ou seja, com $D=0,5$ em meio SF 900 II e com $D=0,5$ em meio SF 900 II suplementado com glutamina. 
Tabela 8: Variáveis calculadas em estado estacionário nas diferentes concentrações de glutamina no meio de alimentação ao longo do Contínuo 3.

\begin{tabular}{|c|c|c|}
\hline \multirow{2}{*}{ Variáveis } & \multicolumn{2}{|c|}{$\mathrm{D}=0,5 \mathrm{dia}^{-1}$} \\
\hline & SF 900 & SF $900+$ GLN \\
\hline $\mathrm{Xv}\left(10^{6} \mathrm{Cel} / \mathrm{mL}\right)$ & 27,7 & 27,4 \\
\hline $\mathrm{CV}(\mathrm{Xv})(\%)$ & 1 & 1 \\
\hline Glicose residual (g/L) & 5,1 & 4,7 \\
\hline CV (Conc. Glicose residual) (\%) & 7 & 1 \\
\hline Glutamina residual (g/L) & 0,56 & 1,13 \\
\hline CV (Conc. Glutamina residual) (\%) & 7 & 3 \\
\hline Amônio (g/L) & 0,3 & 0,34 \\
\hline CV (Conc. Amônio) & 2 & 2 \\
\hline $\mathrm{Y}_{\mathrm{X} / \mathrm{GLC}}$ (célula/g de glicose) & $6,4 \mathrm{E}+09$ & $5,8 \mathrm{E}+09$ \\
\hline $\mathrm{Y}_{\mathrm{X} / \mathrm{GLN}}$ (célula/g de glutamina) & $2,1 E+10$ & $1,2 E+10$ \\
\hline $\mathrm{Y}_{\mathrm{ALA} / \mathrm{GLN}}$ (g de alanina/g de glutamina) & 1,26 & 2,43 \\
\hline $\mathrm{YNH}_{4} / \mathrm{GLN}$ (g de $\mathrm{NH}_{4} / \mathrm{g}$ de glutamina) & 0,19 & 0,39 \\
\hline Teor de GPV $\left(\mu \mathrm{g} / 10^{7}\right.$ cel) & 0,11 & 0,09 \\
\hline Concentração de GPV ( $\mu \mathrm{g} / \mathrm{L})$ & 294 & 254 \\
\hline Produtividade ( $\mu \mathrm{g} / \mathrm{L} . \mathrm{h})$ & 6,1 & 5,3 \\
\hline
\end{tabular}

Como mencionado anteriormente, a concentração celular se manteve constante nas duas condições.

A concentração residual de glicose encontrada nos dois estados estacionários foi alta, indicando que a glicose não foi o substrato limitante. Os fatores de conversão glicose a células também foram próximos nas duas condições, indicando que o $Y_{X / G L C}$ não foi alterado em função da adição de glutamina no meio de alimentação.

No entanto, após a adição de glutamina o $Y_{X / G L N}$ foi reduzido quase pela metade, como já comentado anteriormente. Este fato era esperado, uma vez que foi dobrada a concentração de glutamina e a concentração celular permaneceu a mesma.

Com relação à concentração de GPV, os valores alcançados neste ensaio foram baixos quando comparados a valores encontrados em batelada. Porém, com relação ao Contínuo 1, sob a mesma vazão específica de alimentação, a 
concentração de GPV média deste ensaio foi um pouco maior, $294 \mu \mathrm{g} / \mathrm{L}$ contra 267 $\mu \mathrm{g} / \mathrm{L}$ do Contínuo 1.

O teor de GPV encontrado foi à taxa de diluição de 0,5 dia $^{-1}$ em meio SF 900 II puro e foi de $0,11 \mu \mathrm{g} / 10^{7} \mathrm{cel}$, seguindo de $0,09 \mu \mathrm{g} / 10^{7} \mathrm{cel}$ em SF 900 II suplementado com glutamina (Gráfico 34). Esses valores são próximos aos alcançados no Contínuo $1 \mathrm{com} \mathrm{D}=0,5 \mathrm{dia}^{-1}$.

A adição de glutamina no meio provocou um aumento de $13 \%$ na concentração de amônia e um decréscimo de $18 \%$ no teor de GPV, pode ser que a amônia pode ter inibido a síntese desta proteína.

A produtividade alcançada na taxa de diluição de 0,5 dia ${ }^{-1}$ em meio SF 900 II puro foi de $6,1 \mu \mathrm{g} / \mathrm{L}$.h e no meio SF 900 II suplementado foi de 5,3 $\mu \mathrm{g} / \mathrm{L}$.h. Pode-se notar que a produtividade desse ensaio é próxima a do Contínuo 1 (5,6 $\mu \mathrm{g} / \mathrm{L} . \mathrm{h})$ com a mesma taxa de diluição.

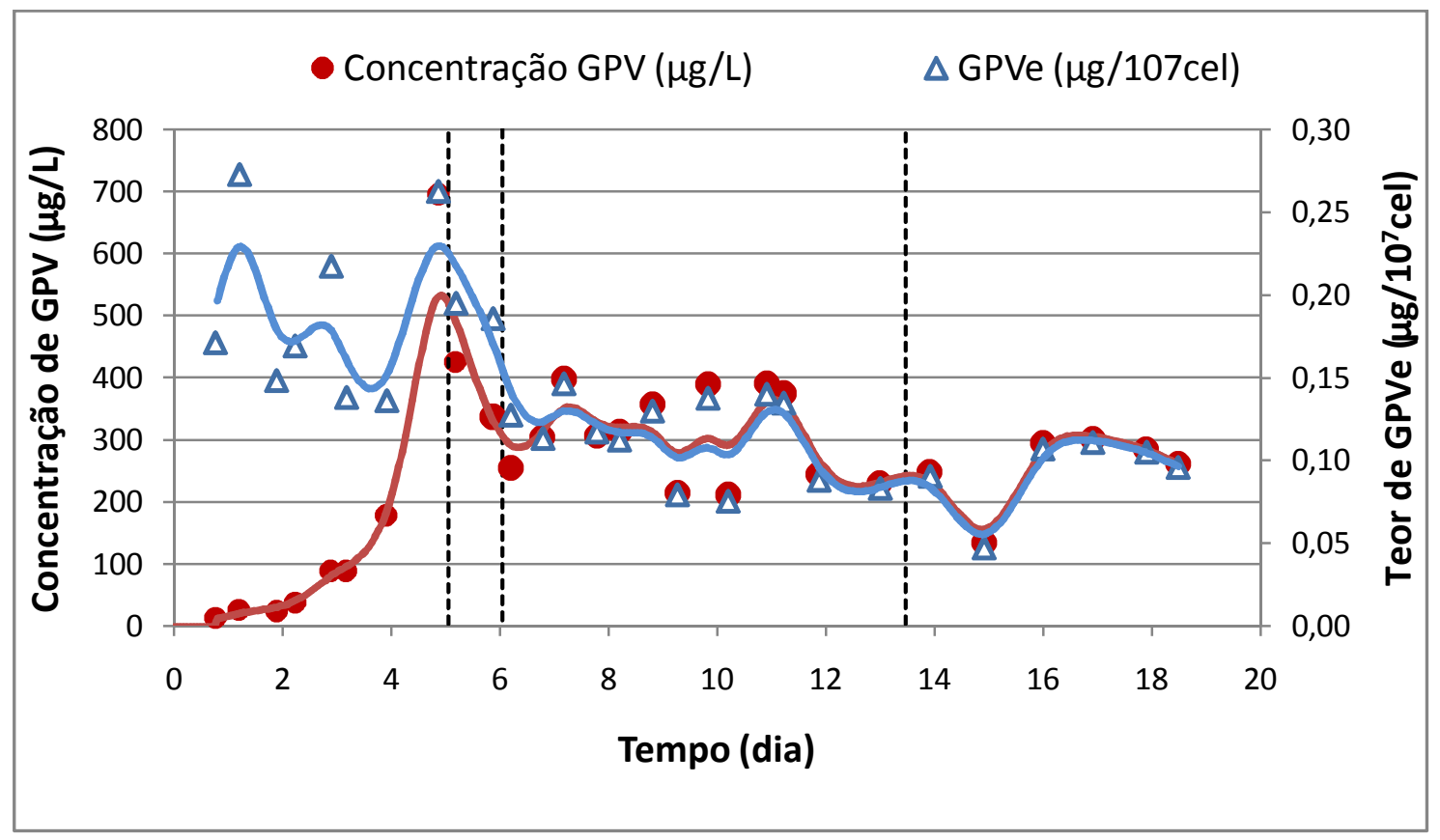

Gráfico 34: Concentração e teor de GPV ao longo do Contínuo 3.

Foram realizadas dosagens de aminoácidos em duas amostras, cada uma representando um estado estacionário (Gráfico 35). Pode-se notar que nos dois estados estacionários alcançados, as concentrações dos aminoácidos foram praticamente iguais. Algumas exceções foram observadas, como por exemplo, a arginina que parece ter sido consumida no estado estacionário com meio SF 900 II. 
Esse fato não foi observado no Contínuo 1, que mostrou que este aminoácido permaneceu constante ao longo dos três estados estacionários alcançados.

A glicina, a histidina e a cisteína apresentaram um maior consumo quando o meio foi suplementado com glutamina.

A asparagina e a serina foram praticamente toda consumida nas duas condições. Pode-se notar também que a produção de alanina foi maior no estado estacionário após adição de glutamina.

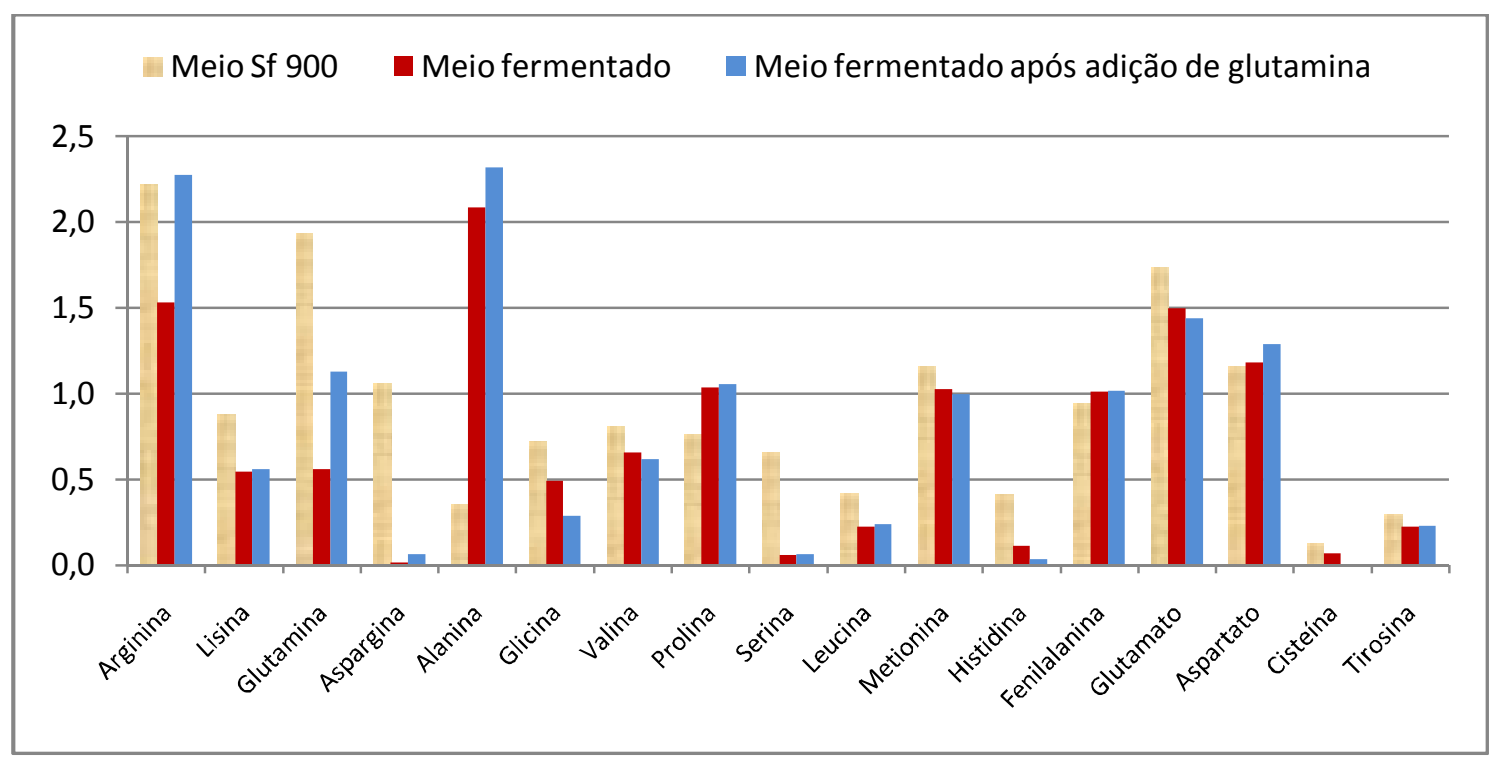

Gráfico 35: Concentração residual de aminoácidos no dois estados estacionários alcançados em comparação com o meio SF 900 II no Contínuo 3.

\subsection{ENSAIO EM SCHOTTS COM DIFERENTES CONCENTRAÇÕES DE AMINOÁCIDOS}

Em consequência dos resultados dos ensaios em schott com diferentes concentrações de glutamina e do ensaio Contínuo 3, ainda em busca de se conhecer o substrato limitante e alcançar maiores concentrações celulares no estado estacionário, foram realizados testes em schott com diferentes concentrações de aminoácidos adicionados ao meio SF 900 II.

A escolha dos aminoácidos foi baseada na concentração residual de todos os aminoácidos dosados nos estados estacionários do ensaio Contínuo 1 e do 
Contínuo 3, ambas com a vazão específica de alimentação igual a 0,5 dia ${ }^{-1}$ e em meio SF 900 II (Gráfico 36).

Pode-se notar que a asparagina, a prolina, a serina, a histidina e a cisteína foram os aminoácidos mais consumidos (com exceção da glutamina que já foi analisada separadamente) e estão representados pelas elipses no Gráfico 36. Estudos anteriores realizados por Swiech (2007) demonstraram que a prolina, serina, glutamina e cisteína também foram os mais consumidos pela linhagem S2AcGPV, chegando, em muitos casos, a exaustão.

Os aminoácidos indicados no Gráfico 36 (envoltos pelas elipses) foram testados nos ensaios em schott, com exceção da histidina, por não estar disponível no laboratório. Apesar da concentração de prolina estar maior que a concentração do meio no estado estacionário do Contínuo 3 , no estado estacionário do Contínuo 1 a concentração é menor e ainda há trabalhos que indicam este aminoácido como substrato limitante do crescimento celular (SWIECH et al., 2008a; ROSSI, 2008).

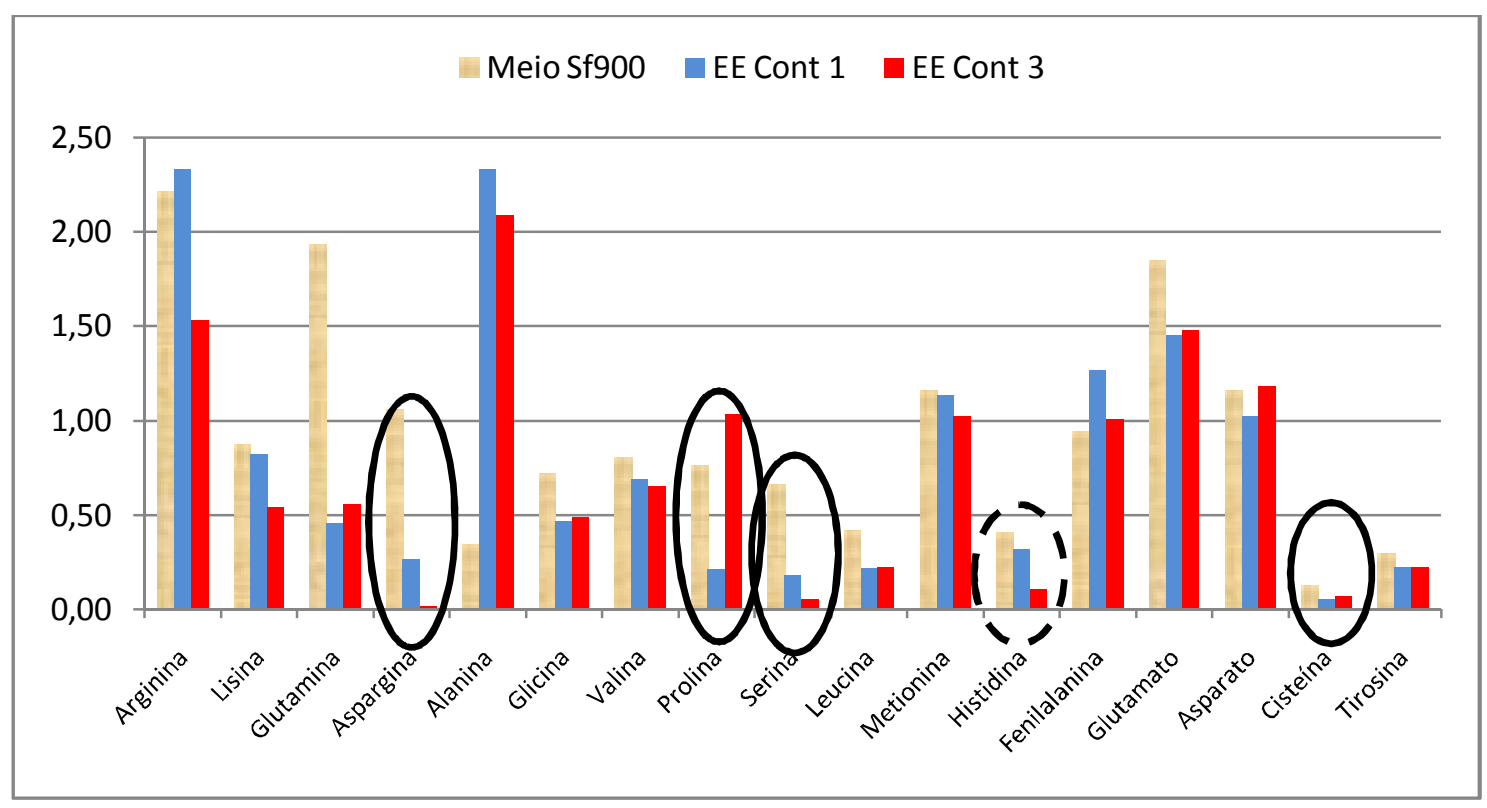

Gráfico 36: Concentração de aminoácidos nos estados estacionários do Contínuo 1 e 3 com $\mathrm{D}=0,5$ dia- 1 e meio SF $900 \mathrm{II}$.

Como a análise de aminoácido do meio de cultura SF 900 II foi realizada antes destes experimentos, pode-se estimar a massa de cada aminoácido necessário para se obter o dobro da concentração inicial. Portanto, o aminoácido foi solubilizado no meio e depois filtrado para garantir a esterilidade. Foi observado que alguns aminoácidos, principalmente a asparagina, possuem baixa solubilidade no 
meio SF 900 II. Foi necessário aquecer o meio de cultura em todos os casos para aumentar a solubilidade no meio.

Com os resultados das análises de aminoácidos de cada meio suplementado para cada ensaio, pode-se determinar a concentração inicial de cada um deles. O meio SF 900 II suplementado com todos os aminoácidos testados, denominado 4 aa, continha 1,46 g/L de Asn, 1,43 g/L de Pro, 1,53 g/L de Ser e 0,29 de Cis. As concentrações obtidas para estes aminoácidos foram próximas as desejadas com exceção da asparagina, que deveria conter $2,1 \mathrm{~g} / \mathrm{L}$ quando na verdade havia $1,46 \mathrm{~g} / \mathrm{L}$. A concentração deste aminoácido neste meio não foi dobrada, como era previsto.

A concentração de asparagina no ensaio Asn também foi menor do que era previsto, 1,35 g/L. Ou seja 0,3 g/L a mais que no meio SF 900 II. Este fato pode estar associado à baixa solubilidade deste aminoácido no meio SF 900 II fazendo com que uma parte tenha ficado retida no filtro.

Para o restante dos ensaios, Pro, Ser e Cis, a concentração de aminoácidos está de acordo com a concentração desejada.

As curvas de crescimento desses ensaios estão apresentadas no Gráfico 37. As concentrações celulares máximas alcançadas nos ensaios foram: no ensaio controle foi de $14,1 \times 10^{6} \mathrm{cel} / \mathrm{mL}$; no ensaio 4 aa foi de $19,8 \times 10^{6} \mathrm{cel} / \mathrm{mL}$; o Asn foi de $11,5 \times 10^{6} \mathrm{cel} / \mathrm{mL}$; o ensaio Pro foi de $8,4 \times 10^{6} \mathrm{cel} / \mathrm{mL}$; o Ser foi de $12,8 \times$ $10^{6} \mathrm{cel} / \mathrm{mL}$; o suplementado com cisteína foi igual a $18,7 \times 10^{6} \mathrm{cel} / \mathrm{mL}$. A duplicata do ensaio Cis foi a que apresentou a maior variabilidade.

Ensaios anteriores realizados por Rossi (2008) com a mesma linhagem celular utilizada neste trabalho em meio SF 900 II suplementado com Pro, Ser, Gln e Cis mostraram que a adição destes aminoácidos não alterou a máxima concentração celular em relação ao meio SF 900 II puro. Porém, vale ressaltar que foi adicionado 0,00672 g/L de cisteína no meio, enquanto que neste trabalho foi adicionado $0,14 \mathrm{~g} / \mathrm{L}$, indicando que a diferença na máxima concentração celular alcançada deve ter sido devido a adição de cisteína.

Com relação à concentração de lactato, pode-se observar que a maior produção foi no ensaio com adição de asparagina, no entanto, alcançando valores menores que 0,12 g/L (Gráfico 38). 
(a)

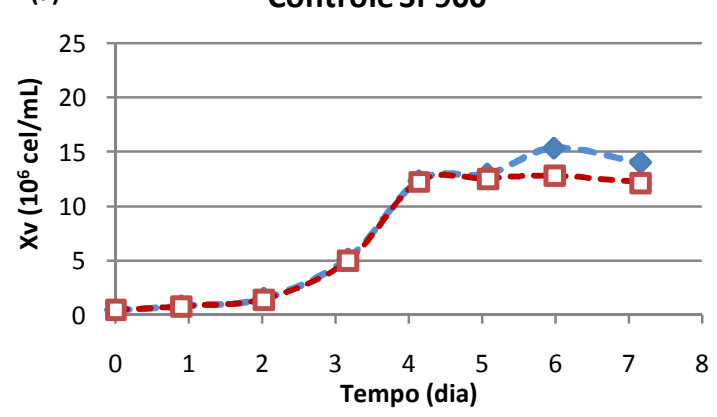

(c)
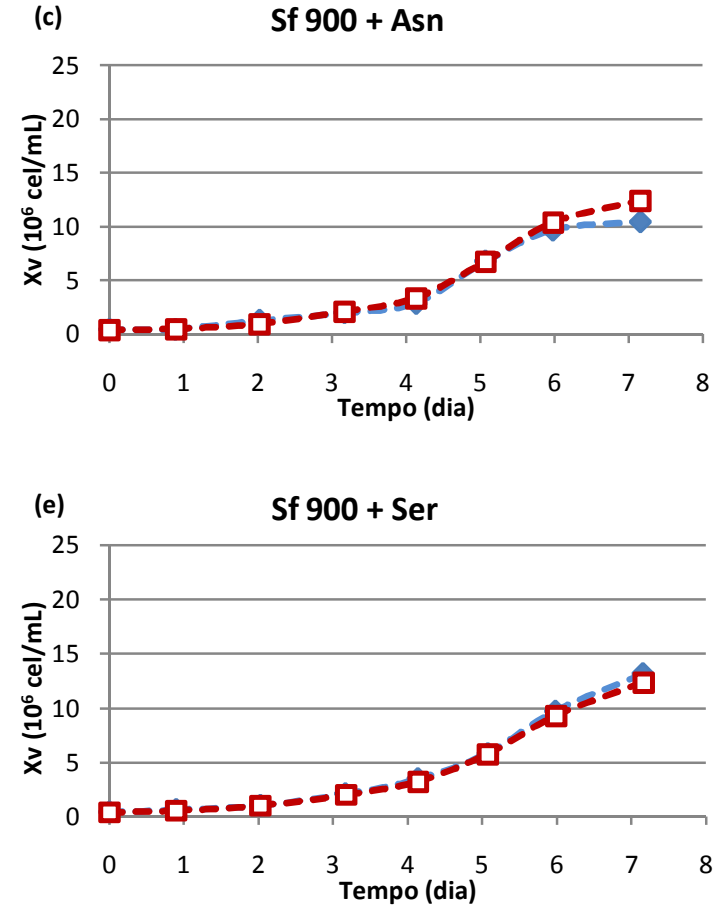

(b) Sf $900+$ Asn, Pro, Ser, Cys

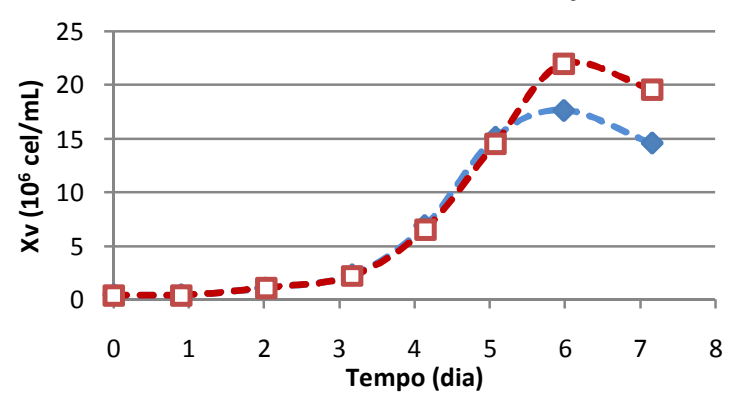

(d) $\quad$ Sf $900+$ Pro
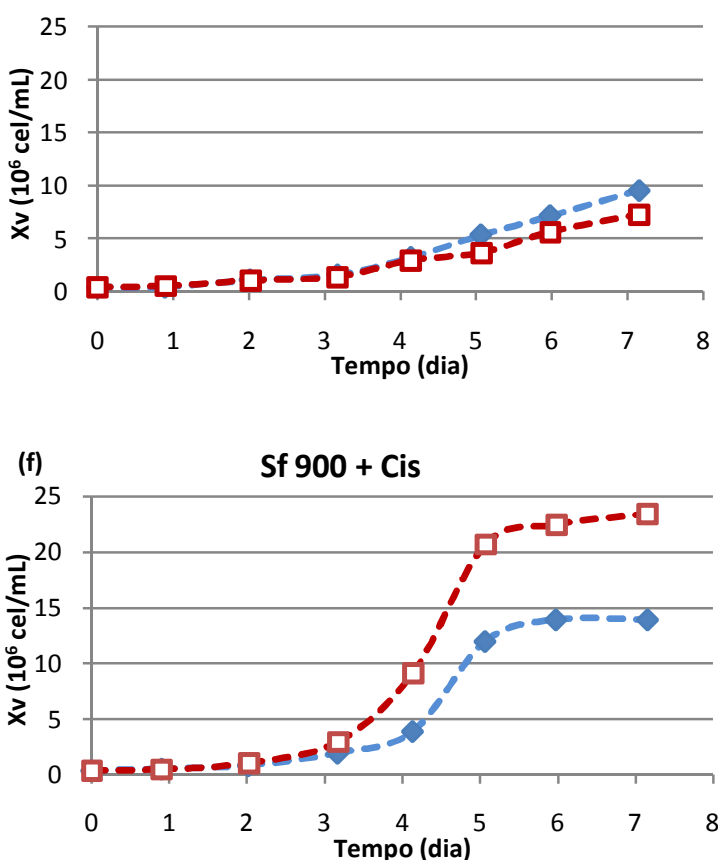

Gráfico 37: Curva de crescimento dos ensaios em schott com diferentes concentrações inicias de aminoácidos. (a) Controle SF 900 II puro, (b) 4 aa ï 2,1 g/L de Asparagina, 1,1 g/L de Prolina, 1,3 g/L de Serina, 0,26 g/L de Cisteína (c) Asn - 2,1 g/L de Asparagina, (d) Pro ï 1,1 g/L de Prolina, (e) Ser $1,3 \mathrm{~g} / \mathrm{L}$ de Serina e (f) Cis - 0,26 g/L de Cisteína.

A concentração de glicose residual no fim do cultivo foi próxima nos schotts suplementados com Asn, Pro e Ser, restando aproximadamente $6 \mathrm{~g} / \mathrm{L}$. No ensaio controle restaram $5,5 \mathrm{~g} / \mathrm{L}$ e no ensaio com adição de todos os aminoácidos e no ensaio Cis, a concentração de glicose residual foi $4,5 \mathrm{~g} / \mathrm{L}$. Tal fato era esperado, pois os ensaios que alcançaram uma maior concentração celular consumiram mais glicose ao longo do ensaio (Gráfico 38). O principal fato foi que a glicose não se esgotou em nenhum dos ensaios, indicando que ela não é o substrato limitante. 

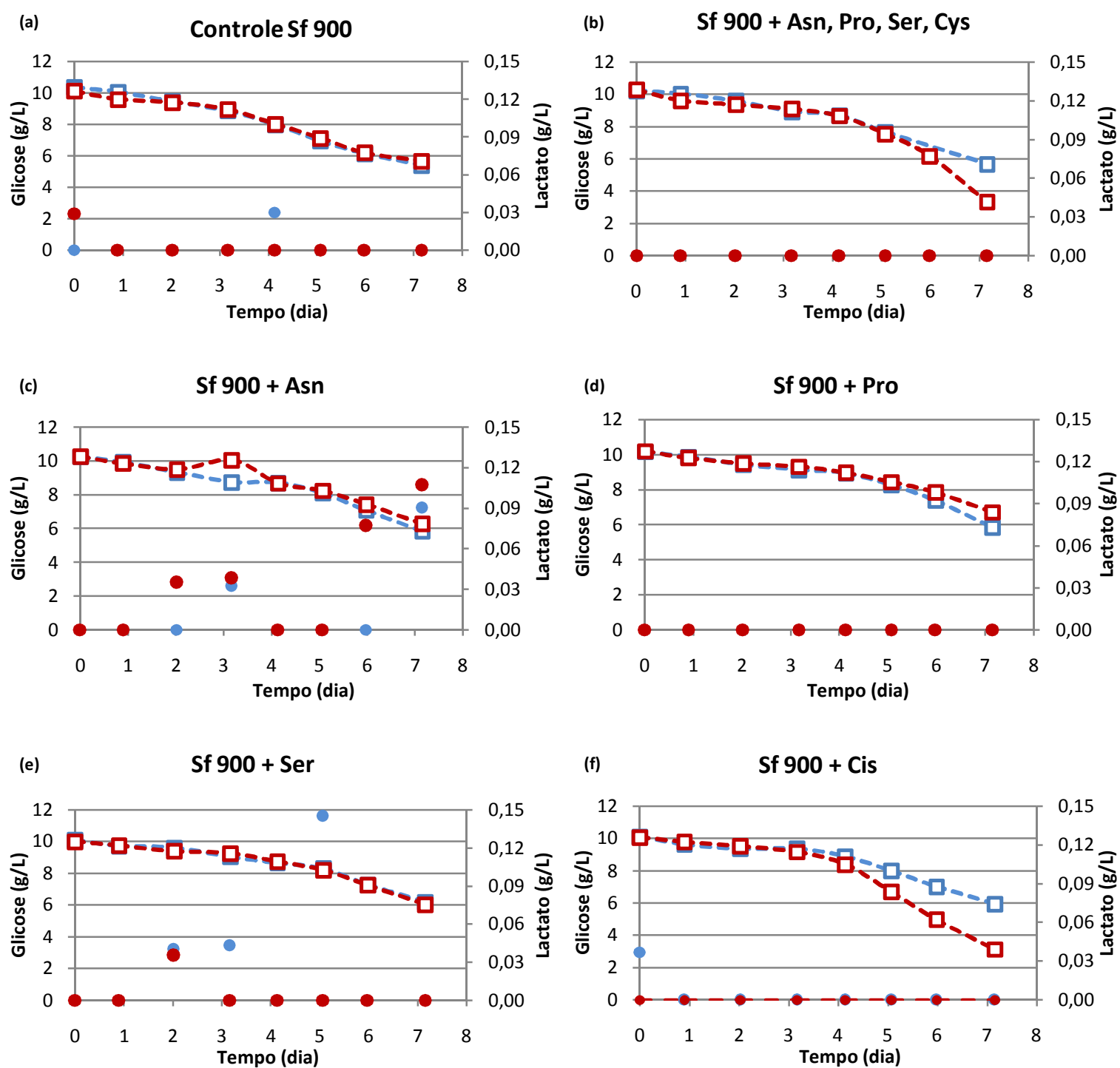

Gráfico 38: Concentração de glicose residual e de lactato dos ensaios em schott com diferentes concentrações inicias de aminoácidos. (a) Controle SF 900 II puro, (b) 4 aa ï 2,1 g/L de Asparagina, 1,1 g/L de Prolina, 1,3 g/L de Serina, 0,26 g/L de Cisteína (c) Asn - 2,1 g/L de Asparagina, (d) Pro ï 1,1 g/L de Prolina, (e) Ser - 1,3 g/L de Serina e (f) Cis - 0,26 g/L de Cisteína. () Glicose, (ǒ) Lactato.

A concentração residual de glutamato no ensaio controle foi próxima as concentrações residuais deste aminoácido no schott com 4 aa e com Cis, ou seja, alcançando valores próximos a 1,5 g/L (Gráfico 39). Nos ensaios Asn, Pro e Ser a concentração de glutamato foi maior e próxima a 1,8 $\mathrm{g} / \mathrm{L}$. Ou seja, o consumo deste aminoácido foi maior nos ensaios que alcançaram maiores concentrações celulares.

Com relação à concentração residual de glutamina, os ensaios Asn e Pro foram os que consumiram menos este aminoácido, restando $0,7 \mathrm{~g} / \mathrm{L}$. Diferentemente destes dois ensaios, o ensaio com adição de serina consumiu a mesma quantidade observada nos ensaios que alcançaram concentrações celulares elevadas, como o controle, com todos os aminoácidos e Cis, restando aproximadamente, 0,2 g/L de 
glutamina. Este fato indica que o consumo de glutamina pode estar associado à produção de GPV, pois o ensaio suplementado com serina foi o que consumiu mais glutamina e apresentou uma maior produção específica de GPV (Gráfico 40e).

(a)

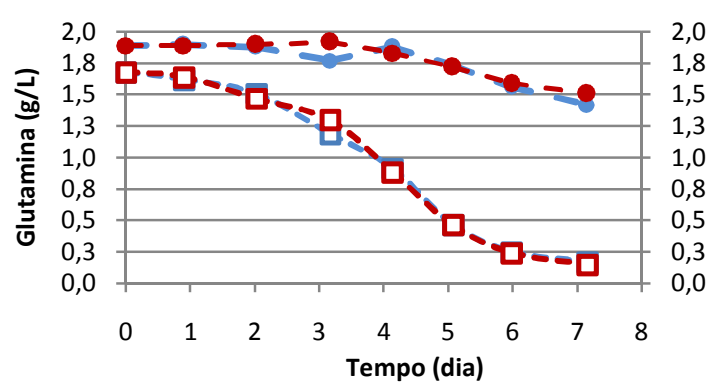

(c)
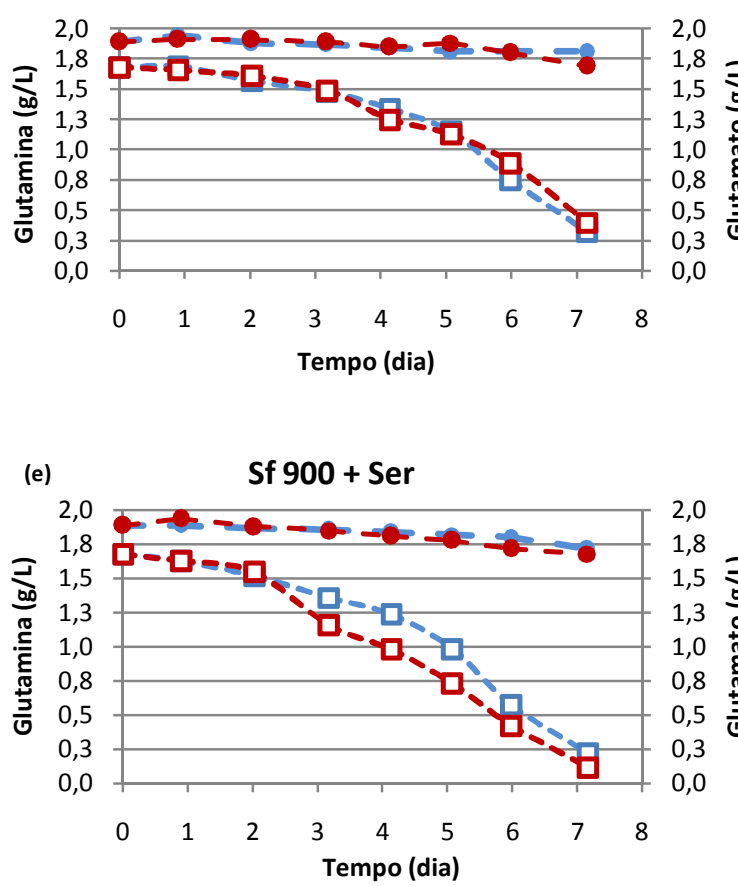

(b) Sf $900+$ Asn, Pro, Ser, Cys
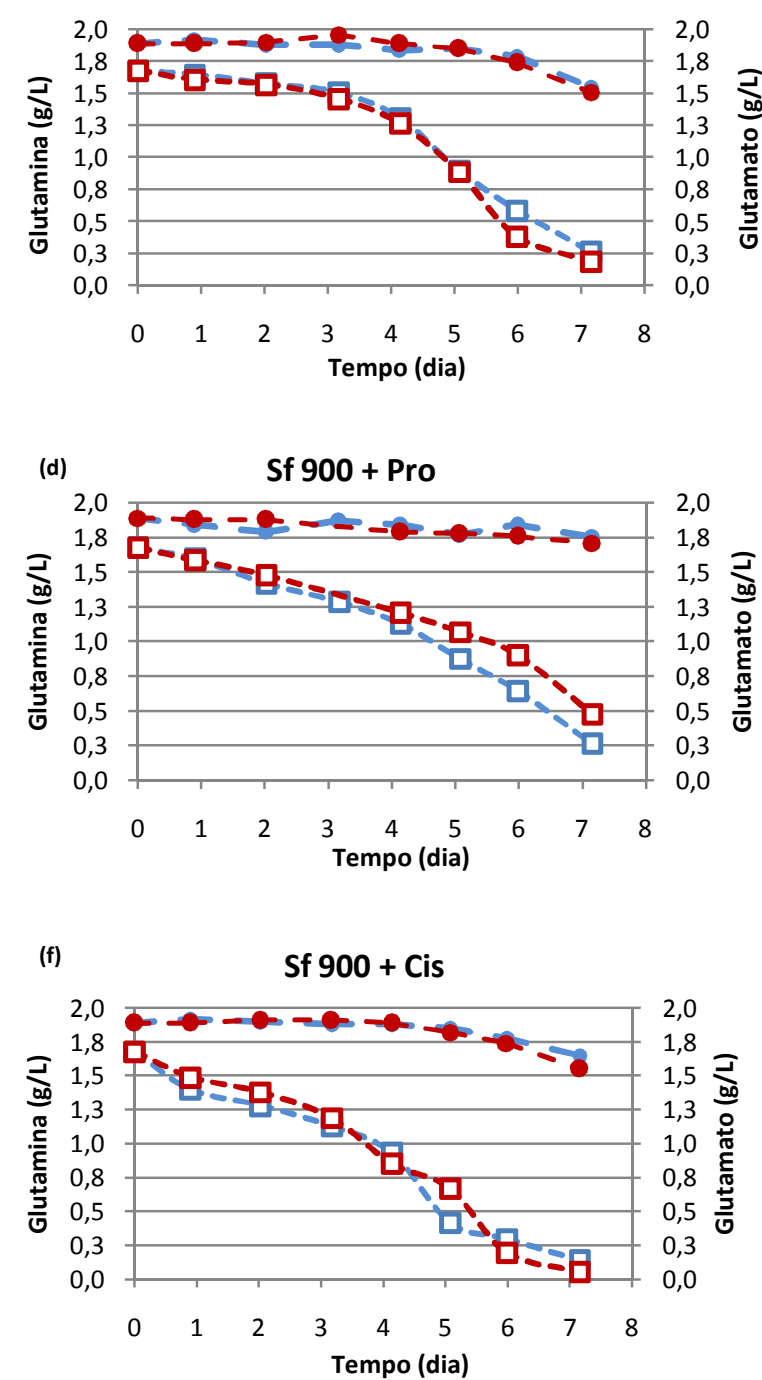

Gráfico 39: Concentração de glutamina e glutamato residual dos ensaios em schott com diferentes concentrações inicias de aminoácidos. (a) Controle SF 900 II puro, (b) 4 aa ï 2,1 g/L de Asparagina, 1,1 g/L de Prolina, 1,3 g/L de Serina, 0,26 g/L de Cisteína (c) Asn - 2,1 g/L de Asparagina, (d) Pro ï $1,1 \mathrm{~g} / \mathrm{L}$ de Prolina, (e) Ser - 1,3 g/L de Serina e (f) Cis - 0,26 g/L de Cisteína. ( $\square$ ) Glutamina, (ǒ) Glutamato.

O Gráfico 40 apresenta as variáveis calculadas $X_{v \text {,máx, }} \mu_{x, \text { máx, }} Y_{X / G L N}$ EXP , $Y_{X / G L C}$ EXP,$G P V e_{\text {máx }}$ e $\Pi_{G P V \text {,máx }}$ para todas as condições. Nos gráficos abaixo os asteriscos sobre as barras indicam a presença de diferenças estatísticas significativas entre as condições testadas e o ensaio controle. 
(a)

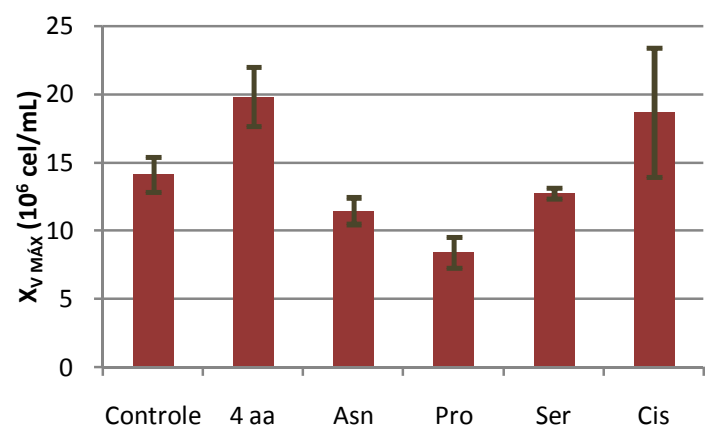

(c)

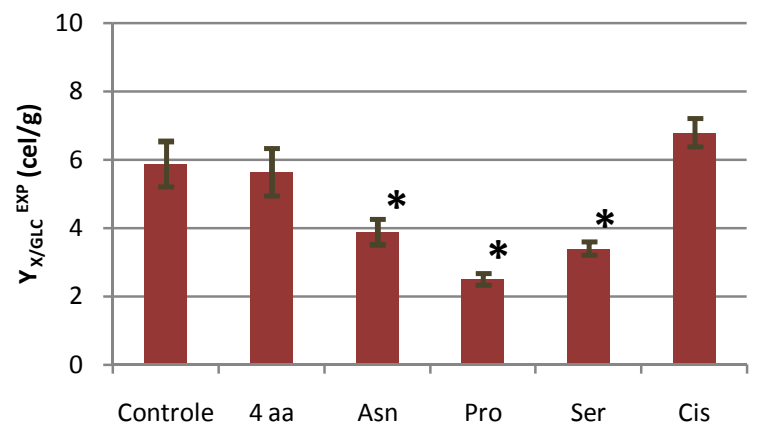

(e)

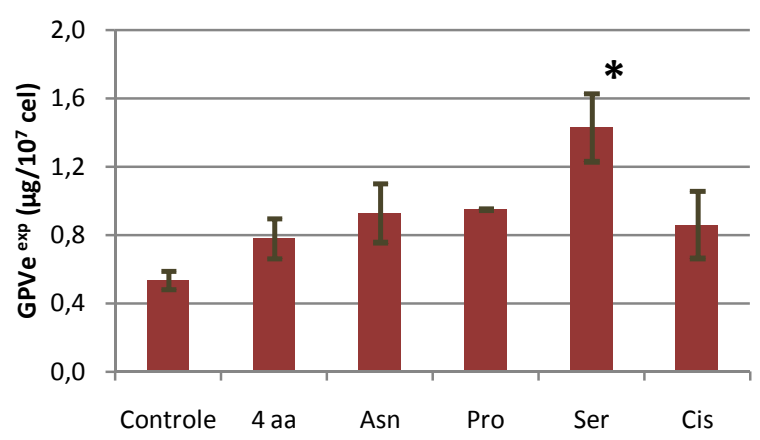

(b)

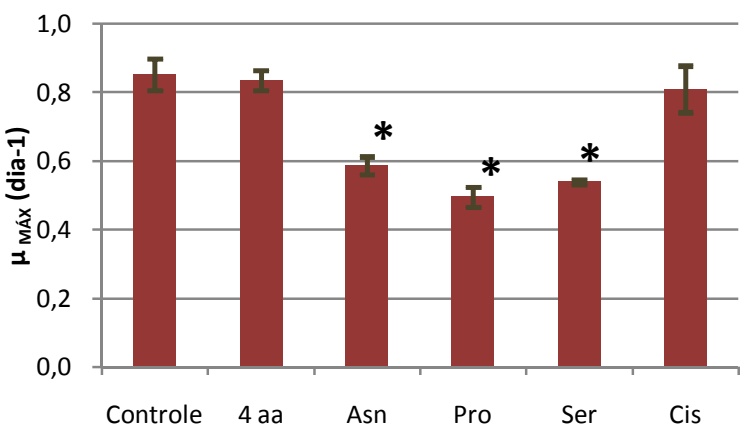

(d)

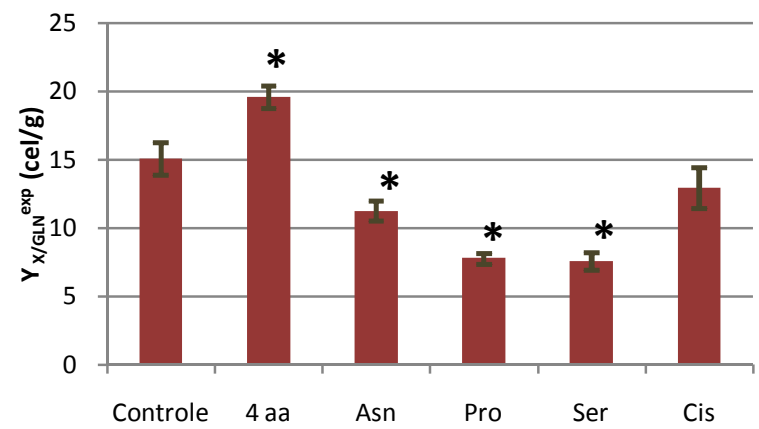

(f)

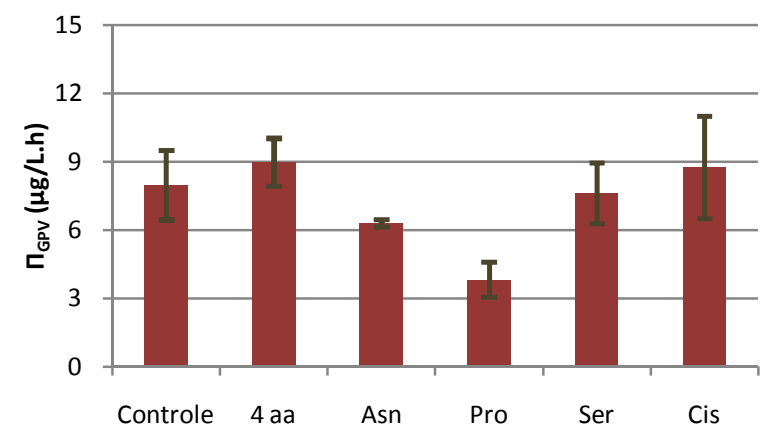

Gráfico 40: Comparação entre os ensaios em schott com diferentes concentrações de aminoácidos no meio SF 900 II. (a) Controle SF 900 II puro, (b) 4 aa ï 2,1 g/L de Asparagina, 1,1 g/L de Prolina, 1,3 g/L de Serina, 0,26 g/L de Cisteína (c) Asn - 2,1 g/L de Asparagina, (d) Pro ï 1,1 g/L de Prolina, (e) Ser - 1,3 g/L de Serina e (f) Cis - 0,26 g/L de Cisteína.

Uma vez que o período da fase exponencial de cada ensaio foi diferente, a comparação entre os $\mathrm{X}_{\mathrm{v} \text {,máx }}$ dos ensaios não representaram bem o conjunto de dados. Por isso, as concentrações celulares máximas comparadas não apresentaram diferenças significativas entre elas.

Com relação à velocidade específica máxima, nota-se com mais clareza que os ensaios controle, 4 aa e Cis alcançaram maiores velocidades em relação aos ensaios Asn, Pro e Ser. Os cálculos da velocidade específica máxima de cada 
ensaio foram realizados baseado na regressão linear do todos os pontos das duplicatas através do programa GraphPad Prism e estão apresentados na Gráfico 40.

Como os ensaios com adição de Asn, Pro, Ser alcançaram uma velocidade específica máxima menor que no ensaio controle, de alguma forma, a adição destes aminoácidos inibiu o crescimento celular (Gráfico 40). No entanto as mesmas concentrações destes aminoácidos foram adicionadas nos schotts com os quatro aminoácidos e este fato não foi observado. É possível que o efeito negativo de um aminoácido tenha anulado o efeito positivo de outro, permanecendo igual ao ensaio controle.

Os ensaios com os quatro aminoácidos (4 aa) e o Cis alcançaram uma velocidade específica máxima de crescimento igual a do ensaio controle. Porém, as fases exponenciais de ambos os ensaios se estenderam até 5,5 dias, ou seja, um dia a mais que o ensaio controle. Isso indica que a cisteína influenciou o fim da fase exponencial de crescimento.

Os maiores fatores de conversão glicose a células durante a fase exponencial foram nos ensaios controle, 4 aa e Cis, alcançando valores entre a 5,7 e $6,8 \times 10^{9} \mathrm{cel} / \mathrm{g}$ glicose e são consideradas estatisticamente iguais. Sendo assim, pode-se afirmar que o rendimento em células com a adição dos quatro aminoácidos juntos e a cisteína (separadamente) foram estatisticamente iguais entre si.

O fator de conversão de glutamina a células foi maior no ensaio com todos os aminoácidos, alcançando $19 \times 10^{9} \mathrm{cel} / \mathrm{mL}$. No ensaio controle este valor foi igual a $15 \times 10^{9} \mathrm{cel} / \mathrm{mL}$ e no ensaio com Cis foi $13 \times 10^{9} \mathrm{cel} / \mathrm{mL}$.

Um fato interessante pode ser ressaltado com relação à GPV específica: a máxima GPVe ocorreu no ensaio com adição de Ser e a menor no ensaio controle. Indicando que a adição desse aminoácido no meio SF 900 II aumenta a síntese da proteína. Segundo Jentoft (1990), a serina participa intensivamente na síntese da proteína através da glicosilação das cadeias laterais, tendo como funções auxiliar no dobramento e proteger a molécula de degradação por protease.

A produtividade do ensaio SF 900 II suplementado com serina só não foi maior devido à concentração celular alcançada durante o cultivo, no entanto, 
alcançou valores próximos a $8 \mu \mathrm{g} / \mathrm{L}$.h. A maior produtividade encontrada ocorreu no ensaio 4 aa e no Cis alcançando, aproximadamente, $9 \mu \mathrm{g} / \mathrm{L} . \mathrm{h}$.

Com os resultados em schott, pode-se afirmar que a adição dos quatro aminoácidos (Asn, Pro, Ser e Cis) no meio SF 900 II provocou um pequeno acréscimo na concentração celular, na produção de GPV específica e na produtividade.

A adição de $0,3 \mathrm{~g} / \mathrm{L}$ de asparagina ao meio SF $900 \mathrm{II}$, contribuiu, principalmente, numa diminuição da velocidade específica máxima de crescimento, diminuição do $X v_{\text {máx }}$, consequentemente, num menor $Y_{X / G L C}{ }^{E X P}$ e menor $Y_{X / G L N}{ }^{E X P}$. Porém, em relação ao controle, houve uma aumento na produção de GPVe.

O ensaio com Pro alcançou uma maior produção de GPV específica em relação ao controle. Porém, nas outras variáveis restantes houve uma diminuição em relação ao controle.

O ensaio com adição de cisteína com relação ao controle alcançou um maior

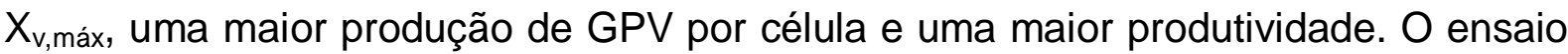
Cis e 4 aa foram semelhantes em todas as variáveis comparadas, com exceção do YX/GLN.

Em geral, os ensaios em schott demonstraram que a adição de Asn, Pro e Ser nessas concentrações utilizadas influenciaram de forma negativa na velocidade específica máxima de crescimento. Em contrapartida, o ensaio com adição de cisteína apresentou um $\mu_{x \text {,máx }}$ igual ao do controle em um período maior da fase exponencial. O aumento na extensão na fase exponencial de um cultivo pode ser realizado pela adição do substrato limitante (SCHMIDELL, 2001). Portanto, é possível que a cisteína seja este substrato.

Com relação ao experimento com adição dos 4 aminoácidos, como dito anteriormente, é possível que o efeito tóxico dos aminoácidos tenha sido anulado. Os dados de rendimento em célula também apontam para este fato, uma vez que nos ensaios com Asn, Pro e Ser foram menores. Ou seja, nestas condições a célula estaria desperdiçando energia, gastando mais energia com a manutenção que para o crescimento. Geralmente, isso é observado quando a célula apresenta uma situação de estresse causado por inibição, tanto por excesso de substrato quanto por metabólitos tóxicos (DREWS; PAALME; VILU, 1995). 
Para melhor entendimento desses fenômenos, o objetivo do próximo ensaio contínuo foi verificar a influência de todos os aminoácidos em conjunto sobre a concentração celular em estado estacionário e, posteriormente, analisar-se a cisteína separadamente.

Em geral, sabe-se que a cisteína é conhecida pela sua função na prevenção da oxidação e na formação de pontes de sulfetos representando um papel importante na estabilização estrutural de proteínas (FREEDMAN, 1990). Porém, os melhores resultados com relação a proteína ocorreu no ensaio com adição de serina.

Estudos para avaliar a influência da cisteína no metabolismo de células Sf9 foram desenvolvidos por Doverskog et al. (1998). Os autores cultivaram as células em batelada em meio de cultura com cisteína $(0,5 \mathrm{~g} / \mathrm{L})$ e sem cisteína. Os autores demonstraram que as células Sf9 podem crescer em meio livre de cisteína desde que a cultura seja iniciada com um inóculo de 47 ï 53 horas. Nestas condições, a velocidade específica máxima de crescimento e a concentração celular máxima alcançada nos experimentos permaneceram as mesmas. Porém, culturas de células

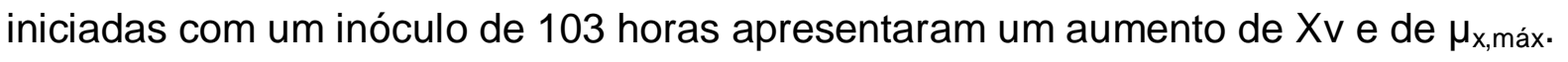

Após esta etapa do trabalho, os autores testaram três diferentes concentrações de cisteína no meio de cultura - 0,1 g/L, 0,5 g/L e 1,0 g/L - com um inóculo de 103 horas. Todos os ensaios alcançaram a mesma concentração celular. No entanto, observou-se que uma maior concentração de cisteína no meio resultou em uma diminuição nos fatores de conversão ( $Y_{X / G L C}, Y_{X / G L N}, Y_{X / G L U}$ e $\left.Y_{X / C I S}\right)$. $O$ consumo de metionina também foi alterado, havendo um decréscimo no consumo com o aumento da concentração de cisteína.

Nos ensaios em schott, não foi possível calcular todos estes fatores de conversão calculados por Doverskog et al. (1998). No entanto, aumentando a concentração de cisteína de 0,131 g/L (meio SF 900 II) para 0,26 g/L não foram observadas alterações no $Y_{X / G L C}$ e $Y_{X / G L N}$. Ambos os fatores de conversão foram estatisticamente iguais. 


\subsection{ENSAIO CONTÍNUO 4}

O ensaio denominado Contínuo 4 foi realizado em processo contínuo com o objetivo de comprovar os resultados obtidos nos ensaios em schott em meio SF 900 II suplementado com diferentes aminoácidos. Porém, este ensaio durou 4 dias em função de uma contaminação por microorganismo não identificado. Assim, um novo ensaio contínuo tornou-se necessário.

\subsection{ENSAIO CONTÍNUO 5}

O ensaio foi realizado nas mesmas condições do Contínuo 1 e do Contínuo 3 na tentativa de isolar ao máximo outros efeitos além da variação na concentração inicial de aminoácidos no meio de alimentação.

Como todo ensaio contínuo se inicia com um descontínuo, nesta fase podese calcular variáveis como $\mu_{\mathrm{X} \text {,máx, }} \mathrm{Y}_{\mathrm{X} / \mathrm{GLC}}{ }^{\text {EXP }}$ e $\mathrm{Y}_{\mathrm{X} / \mathrm{GLN}}{ }^{\text {EXP }}$. O Gráfico 41 apresenta 0 cálculo de $\mu_{x, \text { máx }}$ e a curva de $\mu_{x}$ ao longo do tempo. $O \mu_{x, m a ́ x}$ deste ensaio foi menor o valor encontrado neste trabalho para esta célula.
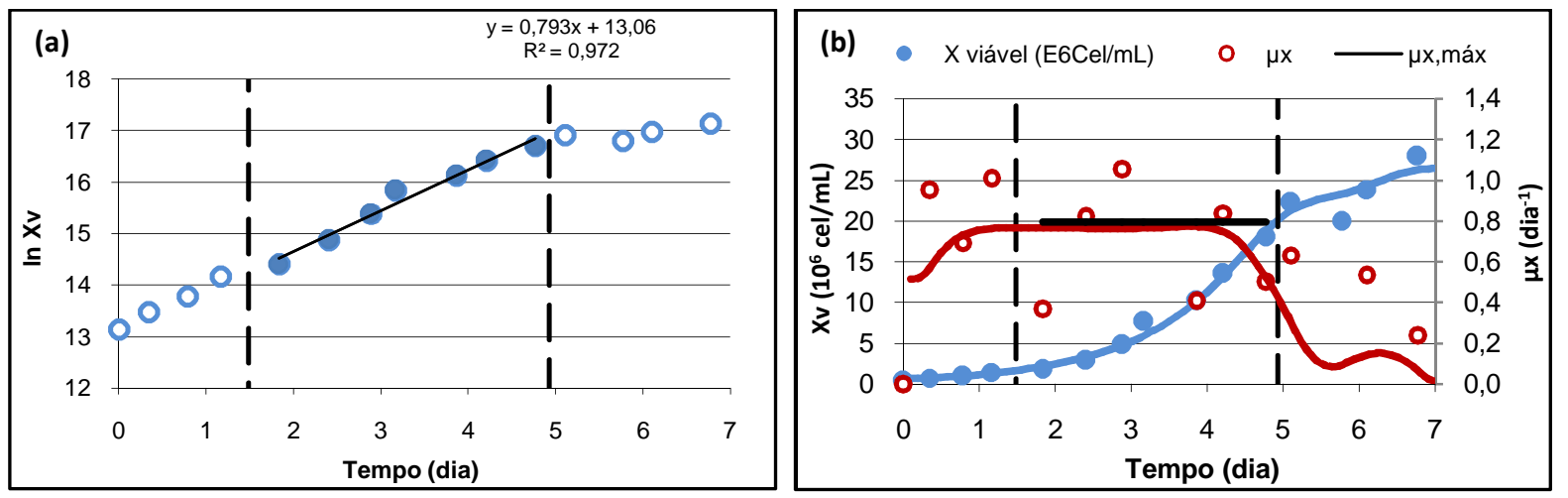

Gráfico 41: (a) Determinação de $\varepsilon_{\text {máx }}$ e (b) Curva de $\varepsilon_{x}$ ao longo do tempo no Contínuo 3.

O processo contínuo foi iniciado a uma vazão de aproximadamente $10,5 \mathrm{~mL} / \mathrm{h}, 250 \mathrm{~mL} / \mathrm{dia}$. Esta vazão representa $\mathrm{D}=0,5 \mathrm{dia}^{-1}$, em um volume de trabalho de $500 \mathrm{~mL}$. Essa condição durou aproximadamente 5 tempos de residência e foi considerado alcançado o estado estacionário, uma vez que ao longo de 2 tempos de residência não houve alterações significativas na concentração celular, 
na concentração de glicose e de glutamina. A concentração celular média foi igual a $26,9 \times 10^{6} \mathrm{cel} / \mathrm{mL}(\mathrm{cV}=1 \%)$.

A concentração residual de glicose foi de $5,0 \mathrm{~g} / \mathrm{L}(\mathrm{cv}=9 \%)$ e a de glutamina foi de 0,42 $\mathrm{g} / \mathrm{L}$ (cv=9\%). Estes valores do coeficiente de variação, como no Contínuo 3 , poderiam ter sido menores se as análises destes substratos fossem realizadas ao longo do ensaio.

Após ter alcançado o estado estacionário, outra condição foi imposta ao ensaio. Com a mesma vazão específica de alimentação, foi alterada a composição do meio de alimentação, isto é, o meio SF 900 II foi suplementado com o 0,1 g/L de asparagina, 0,53 $\mathrm{g} / \mathrm{L}$ de prolina, $0,5 \mathrm{~g} / \mathrm{L}$ de serina e 0,9 $\mathrm{g} / \mathrm{L}$ de cisteína. De forma similar aos ensaios em schott, as concentrações finais desses aminoácidos deveriam estar duplicadas. Porém, devido à dificuldade de solubilização no meio, a adição de asparagina foi prejudicada. No meio SF 900 II a concentração é de $1,06 \mathrm{~g} / \mathrm{L}$ e a concentração final após a adição de 1,08 g em 1 litro de meio foi igual a $1,17 \mathrm{~g} / \mathrm{L}$. Os outros aminoácidos adicionados permaneceram próximos aos valores desejados.

Essa condição durou aproximadamente 3,5 tempos de residência e foi considerado alcançado o estado estacionário. Pode-se notar pelo Gráfico 27 que ao longo desta fase a concentração celular foi praticamente a mesma da fase anterior. A concentração celular alcançada foi de $26,5 \times 10^{6} \mathrm{cel} / \mathrm{mL}(\mathrm{cv}=5 \%)$, a concentração residual de glicose e glutamina foram respectivamente de 5,7 g/L e 0,52 g/L $\left(\mathrm{Cv}_{\text {glicose }}=1 \%, \mathrm{Cv}_{\text {glutamina }}=4 \%\right)$.

Após esta condição, com base nos resultados em schott, o meio SF 900 II foi suplementado com $0,17 \mathrm{~g} / \mathrm{L}$ de cisteína, a uma concentração final de 0,3 g/L (2,3 vezes a mais que a concentração inicial do meio). Essa condição durou 2,2 tempos de residência e foi considerando alcançado o estado estacionário.

Este período foi reduzido devido a uma contaminação identificada por fungo no $29^{\circ}$ dia de cultivo. Entretanto, considerou-se esta etapa em estado estacionário porque o cv para as variáveis analisadas foi menor que $10 \%$. A concentração celular alcançada nesta condição foi $12 \%$ maior que aquela atingida na condição anterior, ou seja, $29,7 \times 10^{6} \mathrm{cel} / \mathrm{mL}(\mathrm{cv}=1 \%)$. Esses resultados indicam que a cisteína limitava o crescimento celular. A concentração residual de glicose e de glutamina 
praticamente manteve-se em relação à condição anterior, ou seja, 5,5 g/L de glicose $(\mathrm{cv}=1 \%)$ e $0,52 \mathrm{~g} / \mathrm{L}$ de glutamina ( $\mathrm{cv}=4 \%)$.

O Gráfico 42 mostra as principais variáveis ao longo do cultivo. Como não houve alterações na temperatura e na velocidade de agitação, ambas não estão representadas no gráfico.

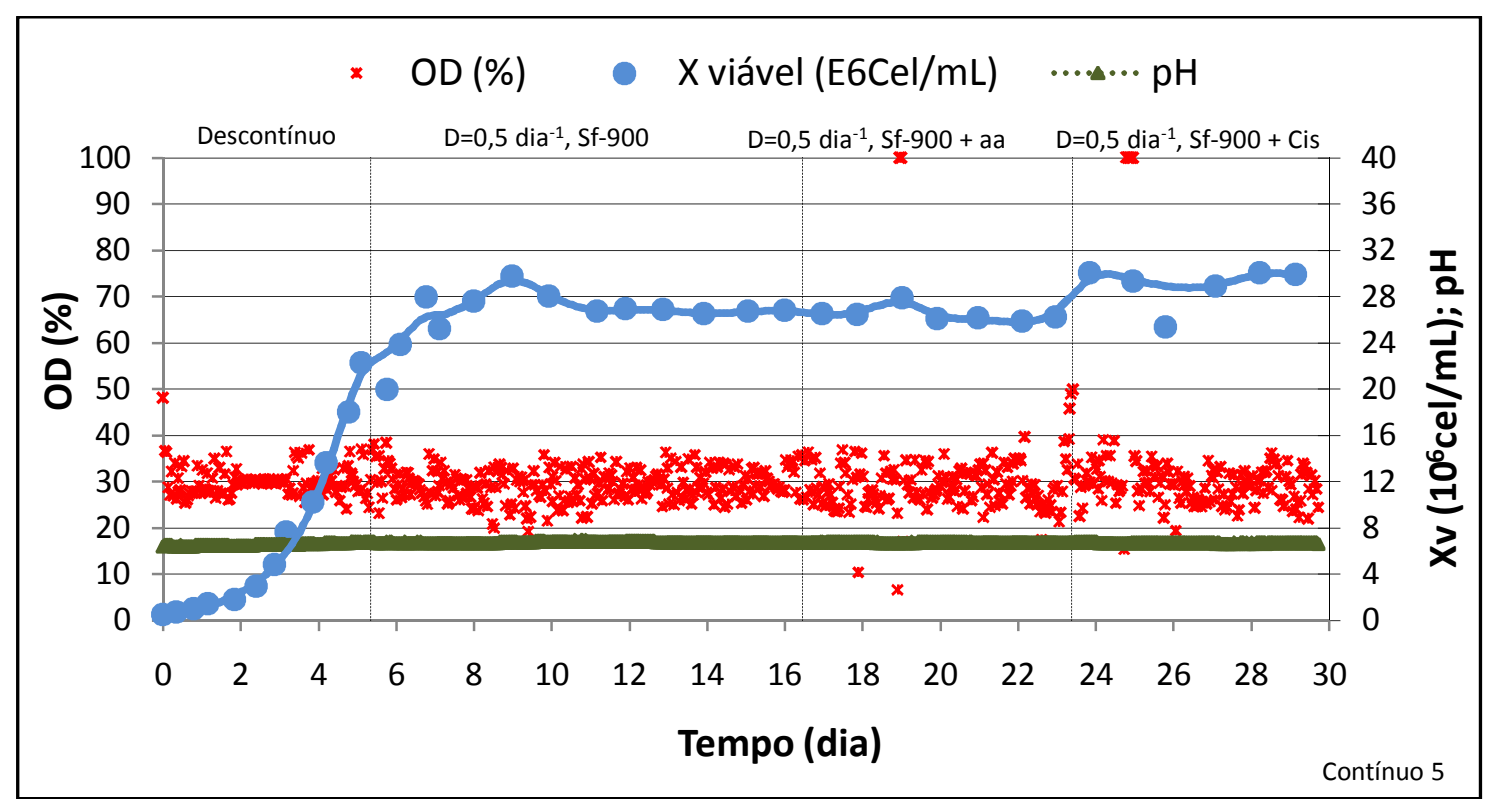

Gráfico 42: OD, pH e a Concentração de células viáveis do Contínuo 5 ao longo do tempo.

A concentração celular total e a viabilidade ao longo do tempo podem ser observadas no Gráfico 43. A viabilidade celular manteve-se alta ao longo do cultivo. A maior concentração celular alcançada foi igual a $29,6 \times 10^{6} \mathrm{cel} / \mathrm{mL}$ no estado estacionário alcançado após adição de cisteína no meio SF 900 II. 


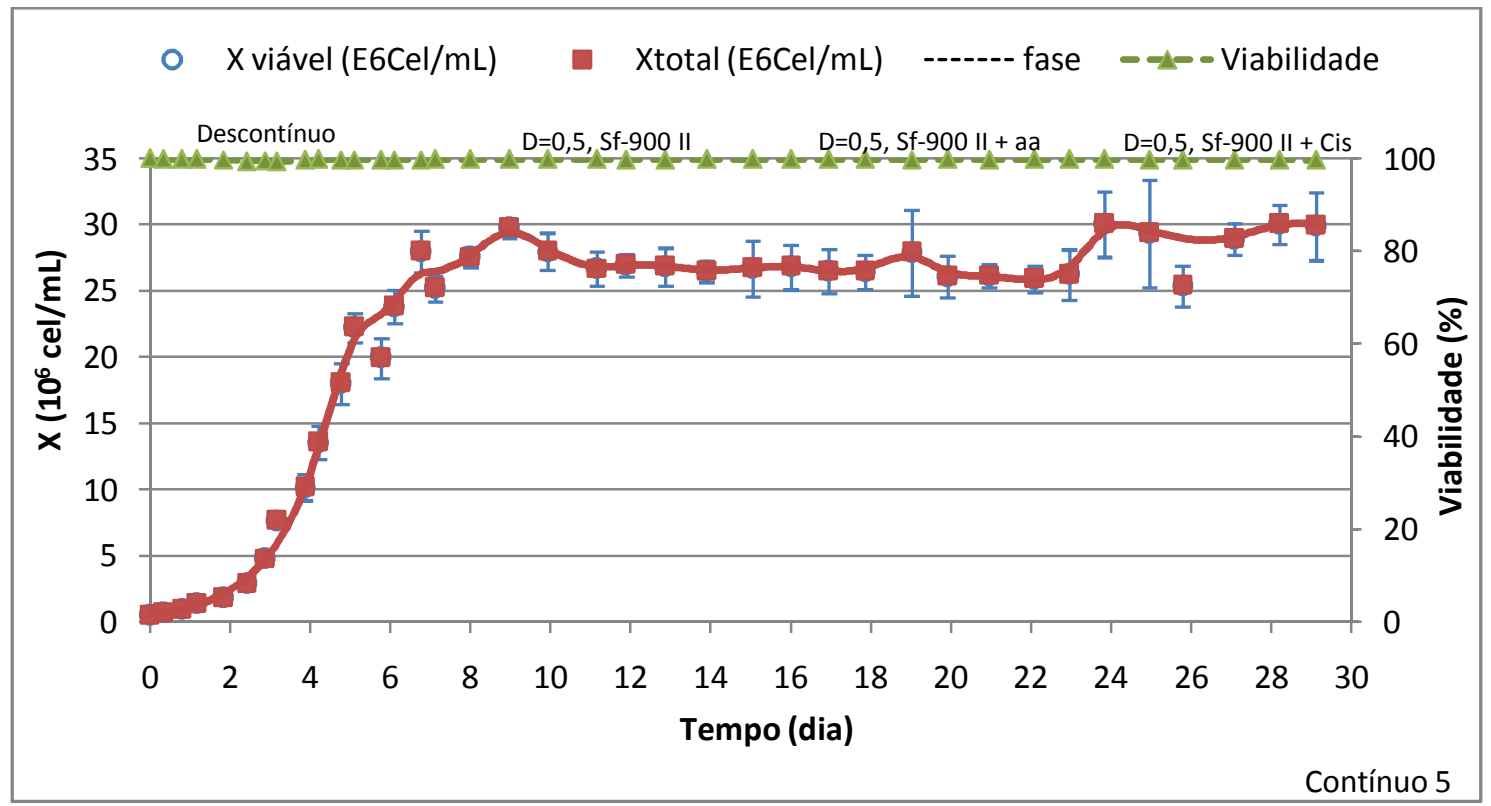

Gráfico 43: Concentração celular e viabilidade ao longo do Contínuo 5.

A concentração de lactato produzido ao longo do ensaio, pode- foi constante e baixa durante todo o cultivo (Gráfico 44). A concentração máxima foi de $0,74 \mathrm{dg} / \mathrm{L}$.

A média da concentração de glicose residual no primeiro estado estacionário foi igual a 5,02 g/L (cv=9\%). Porém observa-se no Gráfico 44 que a variação foi maior que nos outros estados estacionários. Novamente, se a análise de glicose fosse on line este problema poderia ter sido evitado e como consequência o cv seria menor, a nova condição só seria imposta quando a variação da concentração de glicose fosse menor.

Pode-se notar, ainda no Gráfico 44, que a mudança na concentração inicial do meio SF 900 II nas duas diferentes condições não alterou o metabolismo celular com relação ao consumo de glicose, o qual permaneceu constante. Este fato era esperado uma vez que a concentração celular não havia sido alterada em nenhuma das tentativas de suplementação de meio. Porém, ela permaneceu constante mesmo após a adição da cisteína, cuja concentração celular mostrou-se maior. Ou seja, demonstrando que a célula não utilizou a glicose para crescer. 


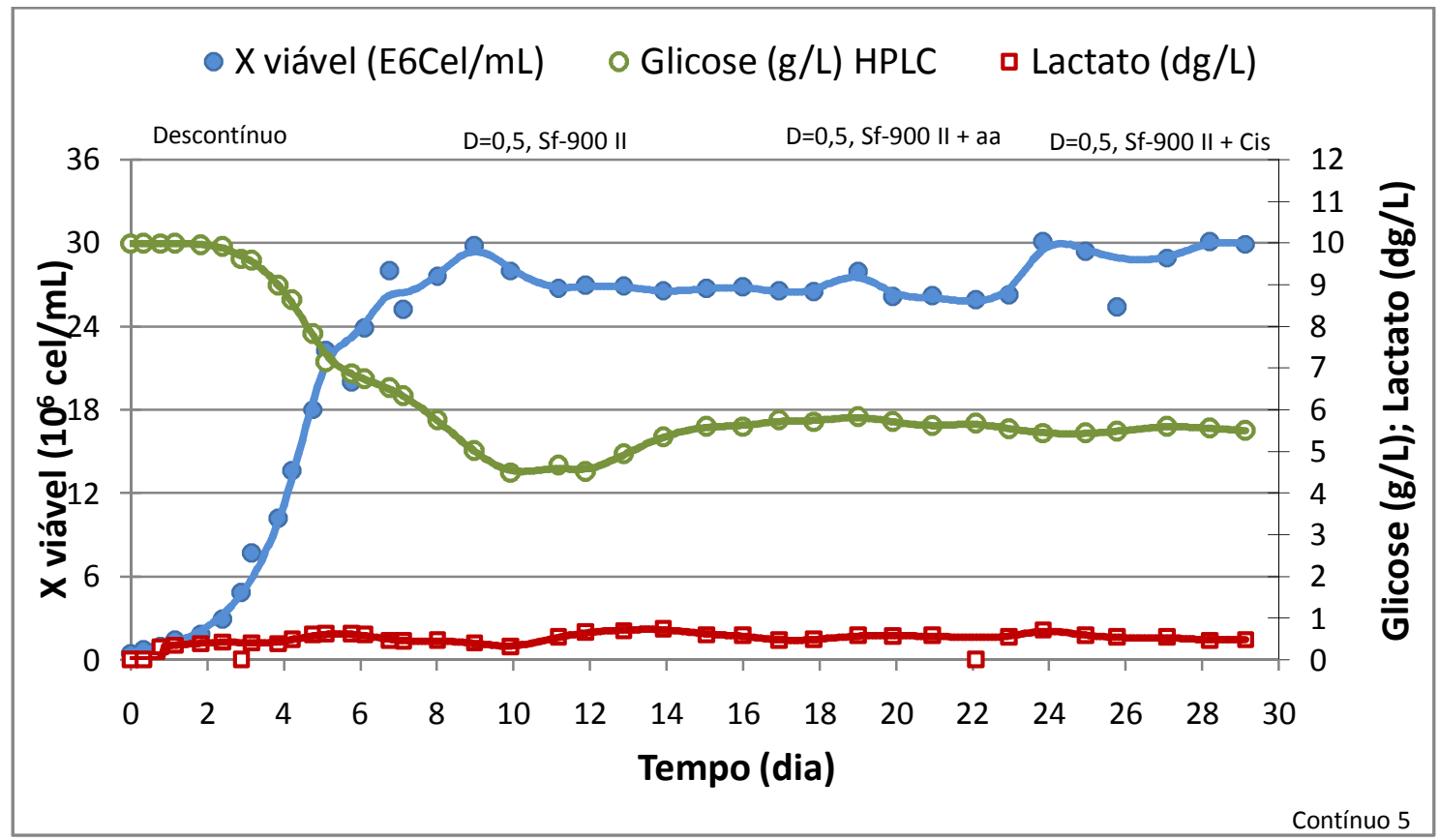

Gráfico 44: Concentração residual de glicose e concentração de lactato ao longo do Contínuo 5.

A concentração de glutamato residual (Gráfico 45) foi praticamente constante nas três diferentes condições de cultivo. Na primeira condição, sua concentração residual foi igual a 1,56 g/L, seguidos de $1,47 \mathrm{~g} / \mathrm{L}$ e $1,45 \mathrm{~g} / \mathrm{L}$. No entanto, o consumo deste aminoácido foi menor após a adição de cisteína. Fato observado também na concentração de glicose e de glutamina residual.

A concentração de glutamina residual no primeiro estado estacionário foi igual a $0,42 \mathrm{~g} / \mathrm{L}(\mathrm{cv}=9 \%)$ e permaneceu constante e igual a $0,52 \mathrm{~g} / \mathrm{L}(\mathrm{cv}=4 \%)$ nas outras duas condições. Portanto, com o meio suplementado com cisteína pode-se afirmar que o consumo de glutamina foi menor, consequentemente, o rendimento em células por grama de glutamina foi um pouco maior que nas outras condições.

Ainda no mesmo gráfico, pode-se notar que a concentração de amônia no estado estacionário em meio SF 900 II puro foi igual a 0,28 g/L com $\mathrm{Y}_{\mathrm{NH} 4 / \mathrm{GLN}}$ igual a $0,19 \mathrm{~g}$ amônia/g glutamina. Depois aumentou com a adição de aminoácidos $(0,35 \mathrm{~g} / \mathrm{L})$ e permaneceu constante após a adição de cisteína $(0,34 \mathrm{~g} / \mathrm{L})$, representando um $\mathrm{Y}_{\mathrm{NH} 4 / \mathrm{GLN}}$ igual a 0,27 g amônia/g glutamina. Esta concentração de amônia, provavelmente, não causou inibição no crescimento celular, uma vez que foi observado um aumento na concentração celular em concentrações similares de amônia no meio. 


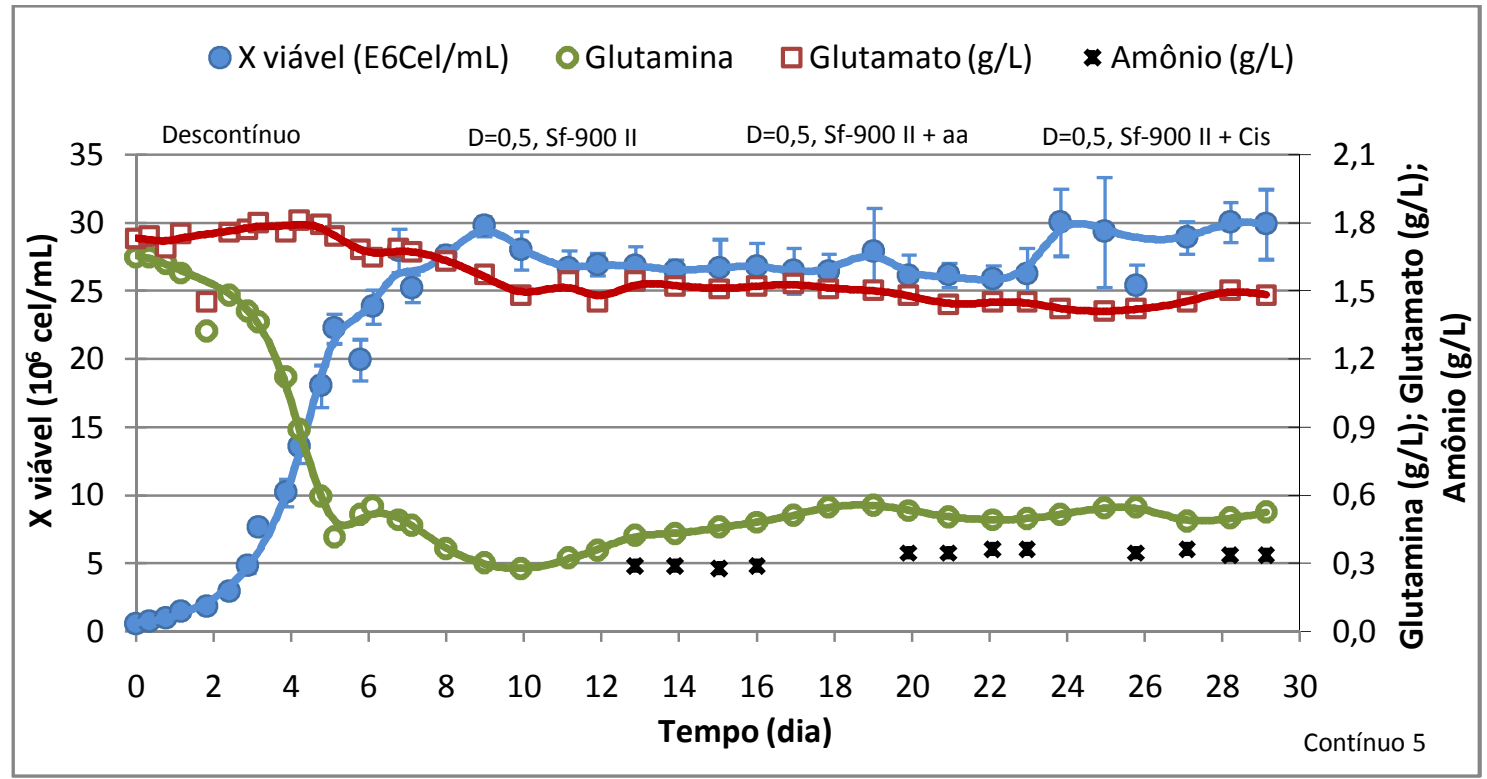

Gráfico 45: Concentração residual de glutamina e glutamato e produção de amônia ao longo do Contínuo 5.

A Tabela 9 mostra as variáveis calculadas do cultivo e a diferença entre elas nas três condições, ou seja, com $D=0,5$ dia $^{-1}$ em meio SF 900 Il; com $D=0,5$ dia $^{-1}$ em meio SF 900 II suplementado com Asn, Pro, Ser e Cis e D=0,5 dia ${ }^{-1}$ em meio SF 900 Il suplementado com cisteína.

Tabela 9: Variáveis calculadas em estado estacionário nas diferentes concentrações de aminoácidos no meio de alimentação ao longo do Contínuo 5

\begin{tabular}{|c|c|c|c|}
\hline \multirow{2}{*}{ Variáveis } & \multicolumn{3}{|c|}{$\mathrm{D}=0,5 \mathrm{dia}^{-1}$} \\
\hline & SF 900 & +4 aа & + Cis \\
\hline $\mathrm{Xv}\left(10^{6} \mathrm{cel} / \mathrm{mL}\right)$ & 26,9 & 26,5 & 29,7 \\
\hline $\mathrm{CV}(\mathrm{Xv})(\%)$ & 1 & 2 & 1 \\
\hline Glicose residual (g/L) & 5,0 & 5,7 & 5,5 \\
\hline CV (Conc. Glicose residual) (\%) & 9 & 1 & 1 \\
\hline Glutamina residual (g/L) & 0,42 & 0,52 & 0,52 \\
\hline CV (Conc. Glutamina residual) (\%) & 9 & 4 & 4 \\
\hline Amônio (g/L) & 0,28 & 0,35 & 0,34 \\
\hline CV (Conc. Amônio) (\%) & 1 & 2 & 3 \\
\hline $\mathrm{Y}_{\mathrm{NH} 4 / \mathrm{GLN}}$ (g de $\mathrm{NH}_{4} / \mathrm{g}$ de glutamina) & 0,19 & 0,27 & 0,27 \\
\hline$\underline{Y}_{\text {ALA/GLN }}$ (g de alanina/g de glutamina) & 1,64 & 1,73 & 2,33 \\
\hline $\mathrm{Y}_{\mathrm{X} / \mathrm{GLC}}$ (célula/g de glicose) & $5,4 \mathrm{E}+09$ & $6,2 E+09$ & $6,6 \mathrm{E}+09$ \\
\hline $\mathrm{Y}_{\mathrm{X} / \mathrm{GLN}}$ (célula/g de glutamina) & $2,19 E+10$ & $2,34 \mathrm{E}+10$ & $2,62 \mathrm{E}+10$ \\
\hline Y Y/CIS (célula/g de cisteína) & $3,13 E+08$ & $1,67 E+08$ & $1,69 E+08$ \\
\hline Teor de GPV $\left(\mu \mathrm{g} / 10^{7} \mathrm{cel}\right)$ & 0,56 & 0,38 & 0,28 \\
\hline Concentração de GPV ( $\mu \mathrm{g} / \mathrm{L})$ & 1520 & 1000 & 811 \\
\hline Produtividade ( $\mu \mathrm{g} / \mathrm{L} . \mathrm{h})$ & 31,6 & 20,8 & 16,9 \\
\hline
\end{tabular}


Como dito anteriormente, a concentração celular se manteve constante nas duas primeiras condições e aumentou $12 \%$ após a adição de cisteína no meio de cultura. Na primeira condição o fator de conversão de cisteína a célula foi igual a 3,1 x $10^{8}$ célula/g cisteína, enquanto que nas outras duas condições foi igual a $1,7 \times$ $10^{8} \mathrm{~g}$ célula/g cisteína. Com isso, pode-se afirmar que a adição destes aminoácidos causou um estresse nas células, representado pelo menor rendimento. Porém, mesmo com este rendimento a adição de somente cisteína resultou em um aumento na concentração celular. Hiller et al. (1993) também observaram um aumento na concentração celular no estado estacionário após a adição de cisteína (juntamente com a metionina) no meio de alimentação.

Com relação à concentração residual de glicose, nos diferentes estados estacionários a concentração foi alta, indicando que a glicose não foi o substrato limitante. O consumo de glicose diminuiu com a adição de aminoácidos no meio. Os fatores de conversão glicose a células também foram próximos nas três condições, indicando que o $Y_{\text {X/GLC }}$ foi levemente aumentado em função da adição de aminoácidos no meio de alimentação.

O mesmo ocorreu com a concentração residual de glutamina. Em todas as condições não houve o esgotamento deste aminoácido, indicando que também não foi o substrato limitante. Com relação ao consumo deste aminoácido, pode-se notar que o maior consumo foi com o meio SF 900 II puro e o menor no meio com adição de cisteína, indicando que a célula consumiu mais aminoácidos mesmo com glutamina residual no meio.

Os valores de $Y_{X / G L C}$ e de $Y_{X / G L N}$ tiveram um pequeno aumento no estado estacionário com adição de cisteína devido ao aumento de $12 \%$ na concentração celular.

Hiller et al. (1993) em cultivos contínuos com células hibridoma observaram que a adição de cisteína e um com vários aminoácidos juntos (Cisteína, Metionina, Histidina, Leucina, Lisina, B6, Isoleucina, Valina e $B_{12}$ - descrito no item 3.5.3) no meio de alimentação diminuíram o consumo específico de glutamina e de oxigênio, porém aumentou o consumo específico de glicose.

Com relação à concentração de GPV (Gráfico 46), na fase descontínua a concentração máxima foi de $300 \mu \mathrm{g} / \mathrm{L}$, enquanto que na Batelada 1 , no mesmo 
período alcançou $2000 \mu \mathrm{g} / \mathrm{L}$. Nos estados estacionário, pode-se notar que existe uma grande variabilidade no primeiro e no último estado estacionário, no entanto, no estado estacionário alcançados após a adição de aminoácidos esta variação foi pequena.

O estado estacionário com SF 900 II puro alcançou uma concentração de GPV média igual $1520 \mu \mathrm{g} / \mathrm{L}$. A concentração média alcançada no estado estacionário seguinte, ou seja, após a adição de aminoácidos, foi de $1000 \mu \mathrm{g} / \mathrm{L}$ e após a adição de cisteína foi igual a $811 \mu \mathrm{g} / \mathrm{L}$.

O teor de GPV máximo encontrado foi à taxa de diluição de $0,5 \mathrm{dia}^{-1} \mathrm{em}$ meio SF 900 II puro e foi de $0,56 \mu \mathrm{g} / 10^{7}$ cel, seguindo de $0,38 \mu \mathrm{g} / 10^{7}$ cel em SF 900 II suplementado asparagina, prolina, serina e cisteína e de $0,28 \mu \mathrm{g} / 10^{7}$ cel no meio suplementado somente com cisteína (Gráfico 46).

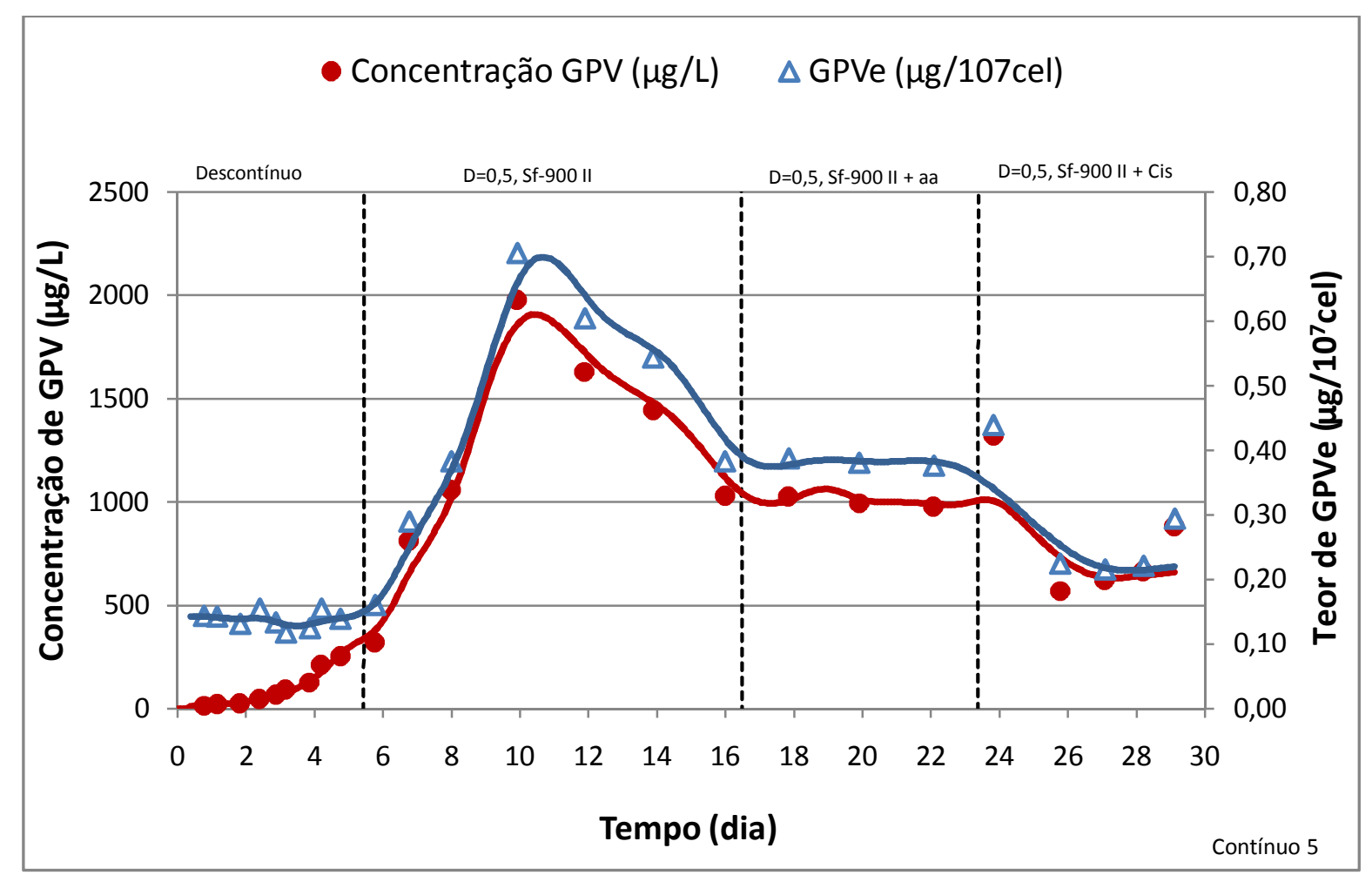

Gráfico 46: Concentração e teor de GPV ao longo do Contínuo 5.

Esta diminuição pode estar associada ao aumento no consumo de aminoácidos, ou seja, um aumento da concentração de metabólitos inibitórios para a produção de GPV. Aguiar (2010), por exemplo, mostrou que concentrações de 
amônio que inibiram a produção de GPV ainda não foram suficientes para uma inibição no crescimento celular.

Portanto, há indícios de que o amônio tenha inibido a produção da proteína. Esta queda no teor de GPV também foi observada no Contínuo 3, em concentrações de amônio bem próximas $(0,34 \mathrm{~g} / \mathrm{L})$.

Outra explicação advém do fato de que estas células não são clones idênticos e sim formam uma população heterogênea (células de embrião em estado tardio de desenvolvimento) (SCHNEIDER, 1972). É possível que com o passar do tempo a mesma vai perdendo a expressão.

A produtividade máxima alcançada na taxa de diluição de 0,5 dia $^{-1}$ em meio SF 900 II puro foi de $41 \mu \mathrm{g} / \mathrm{L}$.h e no meio SF 900 II suplementado com aminoácidos foi de $21 \mu \mathrm{g} / \mathrm{L}$.h e no meio com cisteína foi de $18 \mu \mathrm{g} / \mathrm{L}$.h. Pode-se notar que a produtividade desse ensaio maior que a do Contínuo 1 (6,4 $\mu \mathrm{g} / \mathrm{L} . \mathrm{h})$ e a do Contínuo $3(8,3 \mu \mathrm{g} / \mathrm{L} . \mathrm{h})$.

Foram realizadas dosagens de aminoácidos em seis amostras, três delas indicam a concentração inicial dos meios utilizados (Gráfico 47) e as restantes representam cada uma um estado estacionário (Gráfico 48).

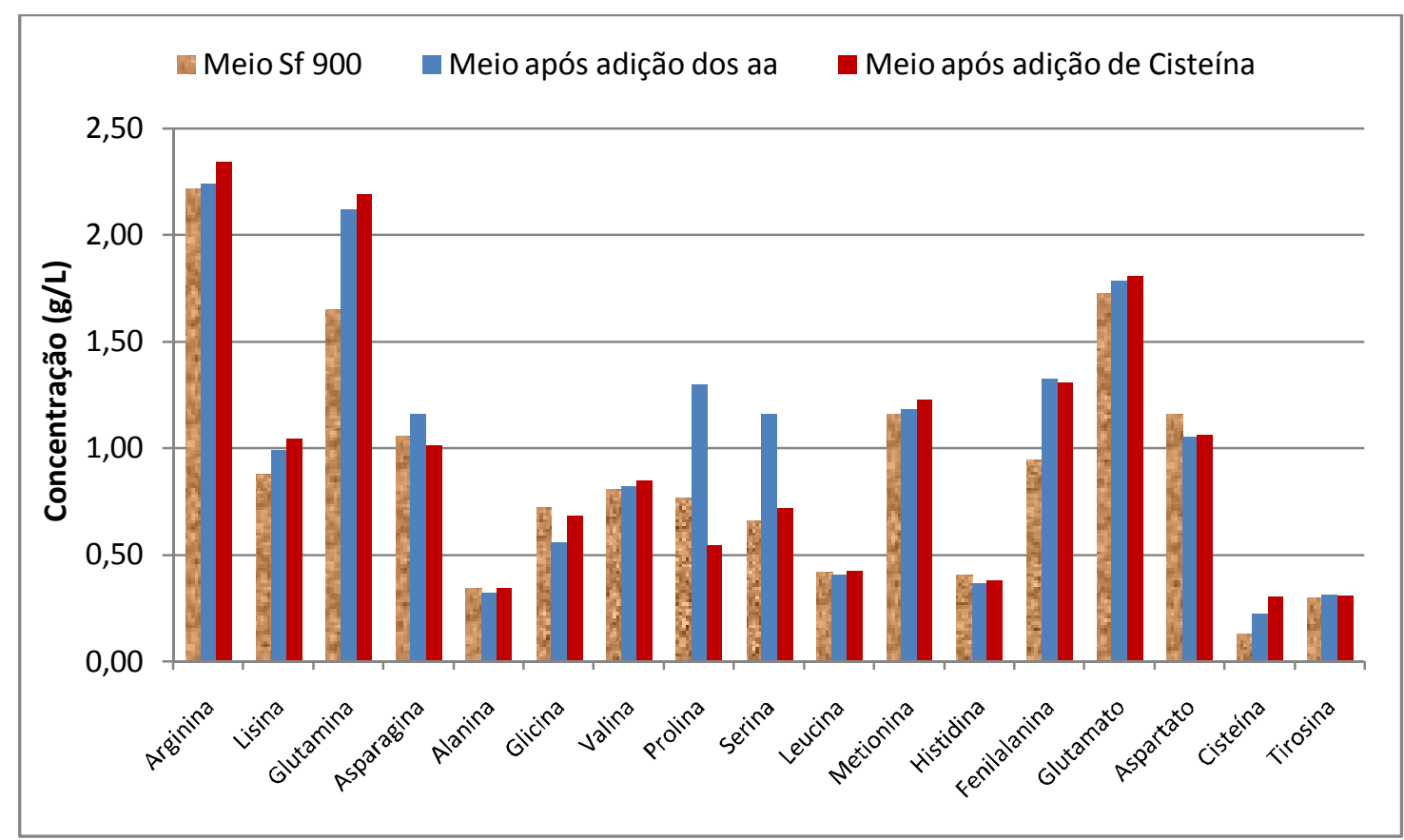

Gráfico 47: Concentração de aminoácidos no meio SF 900 II puro, no meio suplementado com Asn, Pro, Ser e Cis e no meio com Cis utilizado no Contínuo 5. 
Com adição dos aminoácidos no meio SF 900 II pode-se dizer que a concentração final de todos foi praticamente dobrada como desejado. No Gráfico 47 e 48, a asparagina parece não ter sido adicionada ao meio, pois a sua concentração está igual a do meio SF 900 II. No entanto, a concentração de asparagina após a fermentação também está igual à concentração do meio, como se as células não tivessem consumido nada. Este fato é pouco provável, visto que em dois ensaios foram observados o consumo deste aminoácido. Com isso, é possível que a Asn do meio suplementado tenha sido dosado erroneamente e que efetivamente tenha tido seu valor dobrado como desejado.

A concentração final de cisteína deveria ser a mesma nos dois meios suplementados com este aminoácido, porém este fato não foi observado. No meio após a adição de todos os aminoácidos, a concentração final de cisteína foi de $0,224 \mathrm{~g} / \mathrm{L}$ enquanto que no meio suplementado somente com cisteína foi de $0,3 \mathrm{~g} / \mathrm{L}$.

Ainda com relação à cisteína, pode-se notar que o consumo no estado estacionário após a adição dos 4 aminoácidos foi de $0,159 \mathrm{~g} / \mathrm{L}$ e no estado estacionário após a adição de cisteína foi de $0,175 \mathrm{~g} / \mathrm{L}$.

Para facilitar a compreensão, a concentração de aminoácidos no meio de cultura em cada fase foi adicionada no Gráfico 48 juntamente com a concentração de aminoácidos do meio no estado estacionário. 


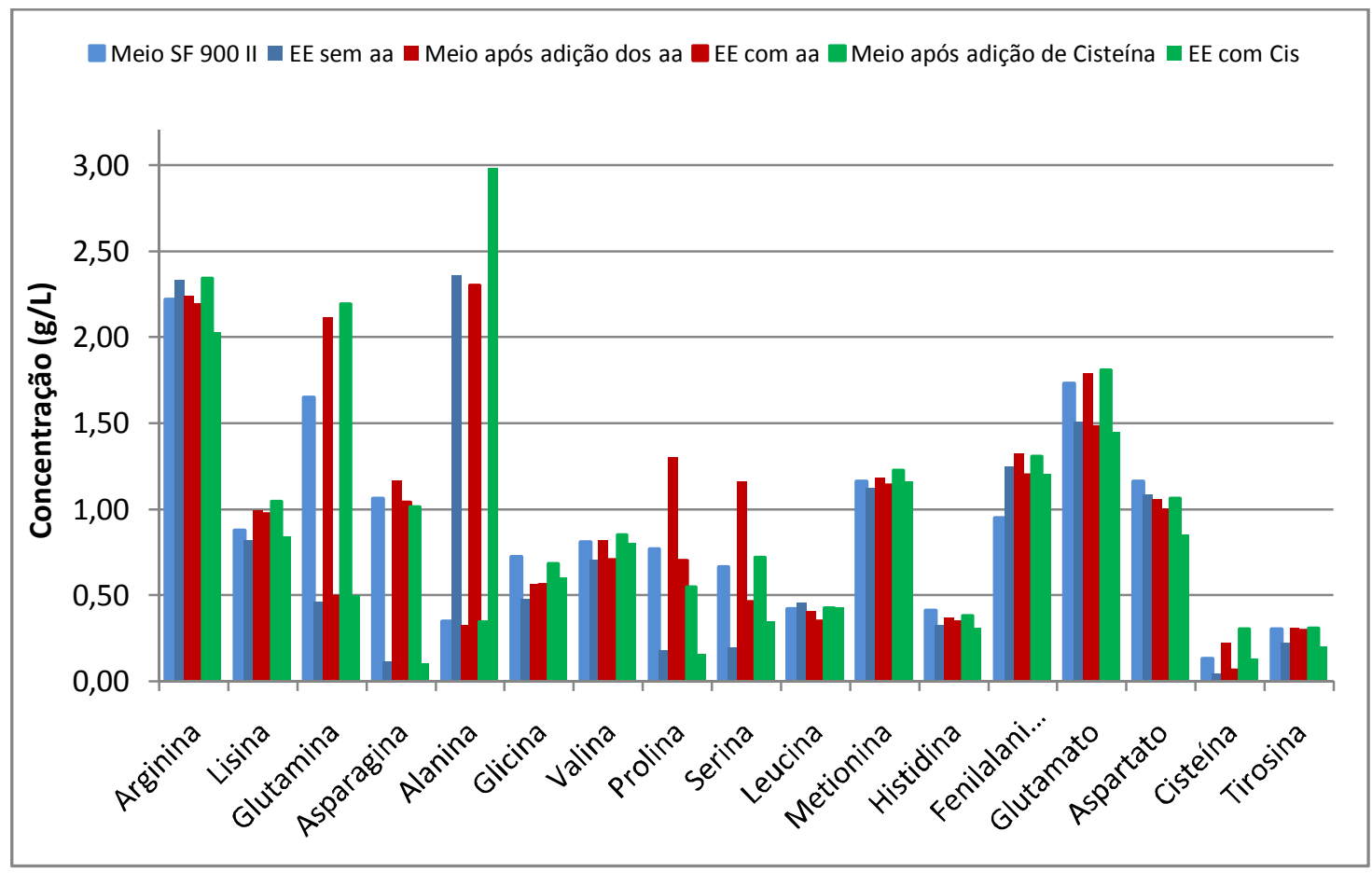

Gráfico 48: Concentração de aminoácidos nos meios de alimentação e nos diferentes estados estacionários alcançados no Contínuo 5.

Da mesma forma que observado nos experimentos em schott, a hipótese de que esses aminoácidos juntos tenham inibido o efeito tóxico observado nos ensaios com somente Asn, Pro e Ser também é valida para o ensaio contínuo. Ou seja, a adição de todos os aminoácidos não alterou a concentração celular quando comparada com o meio SF 900 II puro.

O consumo global de aminoácido após a adição de cisteína no meio foi maior que nas outras duas condições e resultou também em uma maior produção de alanina (Gráfico 48). Porém, concentração de glutamina não foi alterada.

O consumo global de aminoácidos no primeiro (SF 900 II) e no segundo estado estacionário (SF $900 \mathrm{II}+4 \mathrm{aa}$ ) foram iguais a $4,1 \mathrm{~g} / \mathrm{L}$. Portanto, na terceira condição (SF 900 II + cis), o consumo global de aminoácido aumentou para 5,1 g/L. Este aumento no consumo global de aminoácidos que resultou um aumento na concentração celular.

Drews et al. (1995), em cultivos com células Sf9, observaram que mesmo na presença de quantidades significativas de glicose os aminoácidos Asp, Glu, Glu, Asn, Ser, Arg, e Met foram utilizados para a produção de energia. Os autores assumiram também que os grupos amina dos aminoácidos foram utilizados para a síntese de ácidos nucléicos ou transferidos para piruvato e excretados sob a forma 
de alanina. Este fato só foi observado neste trabalho no Contínuo 3, após a adição de cisteína, no qual o consumo de alguns aminoácidos foi maior e a produção de alanina também.

Dorverskog et al. (1998), em cultivos com células Sf9, também observaram que o meio de cultivo com adição de cisteína provocou um aumento no consumo global de aminoácidos, que no caso deles foram a tirosina, valina, isoleucina e leucina.

Esses fatos comprovam a afirmação de Finkelstein et al. (1998) que a cisteína é um componente chave que influencia o consumo e o metabolismo de outros aminoácidos.

A Tabela 10 ilustra o consumo e a produção (valores destacados em vermelho) de aminoácidos em relação ao meio SF 900 II puro. Pode-se observar que os aminoácidos mais consumidos (entre os três estados estacionários) após a adição de cisteína foram a arginina, lisina e aspartato.

Tabela 10: Consumo e produção de cada aminoácido nos estados estacionários do Contínuo 3.

\section{Aminoácidos}

$$
\text { EE em aa } \quad \text { EE com aa } \quad \text { EE com Cis }
$$

\begin{tabular}{|c|c|c|c|}
\hline & g/L & $g / L$ & g/L \\
\hline Arginina & $-0,120$ & 0,052 & 0,317 \\
\hline Lisina & 0,057 & 0,018 & 0,205 \\
\hline Glutamina & 1,192 & 1,626 & 1,693 \\
\hline Asparagina & 0,945 & 0,124 & 0,912 \\
\hline Alanina & $-2,017$ & $-1,979$ & $-2,637$ \\
\hline Glicina & 0,242 & 0,002 & 0,080 \\
\hline Valina & 0,104 & 0,117 & 0,047 \\
\hline Prolina & 0,589 & 0,599 & 0,390 \\
\hline Serina & 0,466 & 0,697 & 0,372 \\
\hline Leucina & $-0,033$ & 0,058 & $-0,003$ \\
\hline Metionina & 0,038 & 0,043 & 0,064 \\
\hline Histidina & 0,084 & 0,023 & 0,071 \\
\hline Fenilalanina & $-0,303$ & 0,125 & 0,102 \\
\hline Glutamato & 0,220 & 0,309 & 0,360 \\
\hline Aspartato & 0,075 & 0,063 & 0,211 \\
\hline Cisteína & 0,086 & 0,159 & 0,175 \\
\hline Tirosina & 0,075 & 0,016 & 0,104 \\
\hline
\end{tabular}




\subsection{COMPARAÇÃO ENTRE OS ENSAIOS CONTÍNUOS}

Como os todos os ensaios contínuos tiveram uma condição com uma mesma vazão específica de alimentação $\left(0,5 \mathrm{dia}^{-1}\right)$ e com o mesmo meio SF 900 ॥I foi possível fazer uma comparação ou validação entre eles.

Com o intuito de conhecer a variabilidade destas células, antes de analisar os dados em estado estacionário, foi realizada uma comparação entre as fases em processo descontínuo de cada ensaio.

As variáveis comparadas foram: máxima concentração celular, velocidade especifica máxima de crescimento, consumo de glicose e de glutamina na fase exponencial, teor de GPV máximo e máxima produtividade alcançada na fase exponencial. Estes resultados são mostrados na Tabela 10.

Sabendo que todos os ensaios se iniciaram com condições de cultivos idênticos, pode-se notar que as variações entre cada ensaio foram elevadas, com os coeficientes de variação superiores a $20 \%$. Os dados relacionados à GPV foram os que obtiveram um maior coeficiente de variação.

Vale lembrar que as fases descontínuas dos 3 ensaios deveriam ser perfeitas repetições, com exceção ao fato de utilizarem inóculos descongelados em momentos diferentes.

Tabela 11: Variáveis calculadas na fase descontínua dos ensaios Contínuos.

\begin{tabular}{|c|c|c|c|c|c|c|}
\hline $\begin{array}{c}\text { Fase } \\
\text { descontínua }\end{array}$ & $\begin{array}{l}\mu_{x, \operatorname{máx}} \\
\left(\text { dia }^{-1}\right)\end{array}$ & $\begin{array}{c}X v^{\exp } \\
(\mathrm{E} 6 \mathrm{cel} / \mathrm{mL})\end{array}$ & $\begin{array}{l}\text { Consumo de } \\
\text { Glicose } \\
\text { (g/L) }\end{array}$ & $\begin{array}{c}\text { Consumo de } \\
\text { Glutamina } \\
\qquad(\mathrm{g} / \mathrm{L})\end{array}$ & $\begin{array}{c}G P V e^{\exp } \\
(\mu g / E 7 \text { cel) }\end{array}$ & $\begin{array}{l}\text { Produtividade } \\
\text { máxima }^{\text {exp }} \\
(\mu \mathrm{g} / \mathrm{L} . \mathrm{h})\end{array}$ \\
\hline Contínuo 1 & 1,22 & 24,55 & 3,33 & 0,82 & 0,47 & 7,64 \\
\hline Contínuo 3 & 1,05 & 12,97 & 1,55 & 0,64 & 0,27 & 6,92 \\
\hline Contínuo 5 & 0,79 & 18,03 & 2,19 & 1,06 & 0,15 & 2,48 \\
\hline CV (\%) & 21 & 31 & 38 & 24 & 53 & 49 \\
\hline
\end{tabular}

O Gráfico 49 mostra os três estados estacionários alcançados nos ensaios contínuos com $\mathrm{D}=0,5 \mathrm{dia}^{-1}$ em meio SF 900 II puro. É possível notar que para estas variáveis a diferenças entre os ensaios foram pequenas, com exceção da GPV. Essa 
diferença também foi indicada pelo coeficiente de variação entre os estados estacionários.

A concentração celular variou entre $25,3 \times 10^{6} \mathrm{cel} / \mathrm{mL}$ e $27,7 \times 10^{6} \mathrm{cel} / \mathrm{mL}$ com um coeficiente de variação entre elas igual a 4\% (Gráfico 49a).

A concentração residual de glicose (Gráfico 49b) foi semelhante nos três estados estacionários, variando entre 5,02 e 5,21 g/L. com um coeficiente de variação de $1 \%$.

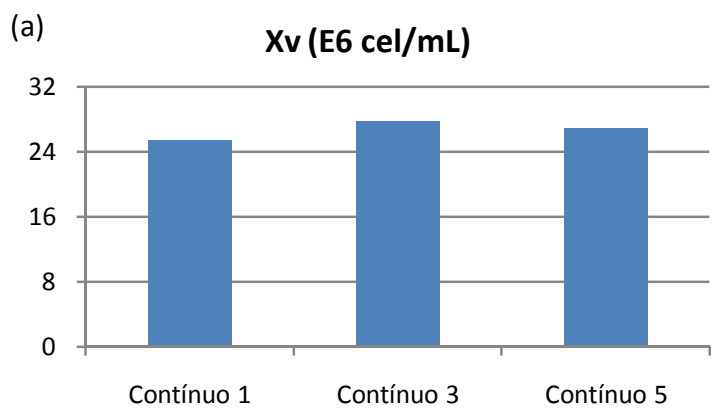

(c)

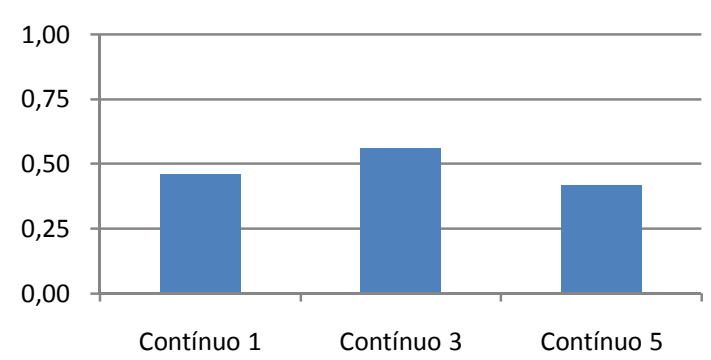

(e)

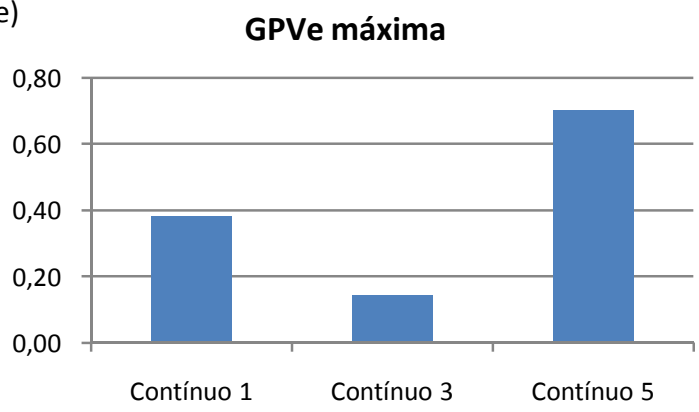

(b) Glicose Residual

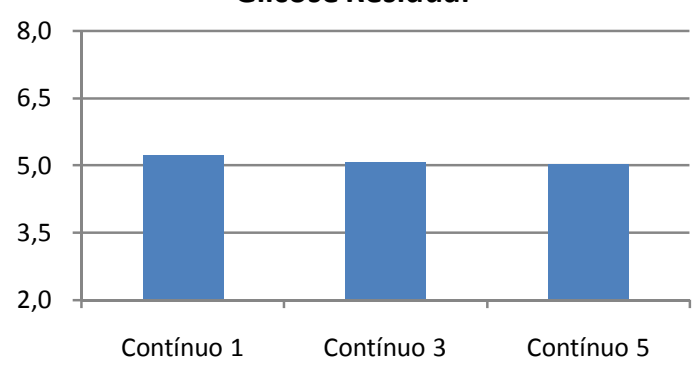

(d)

Amônio (g/L)

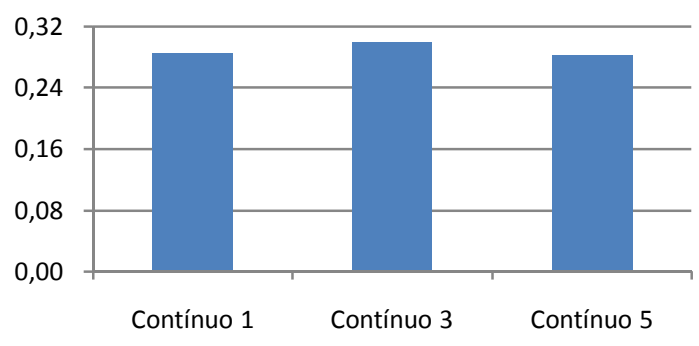

(f)

Produtividade máxima

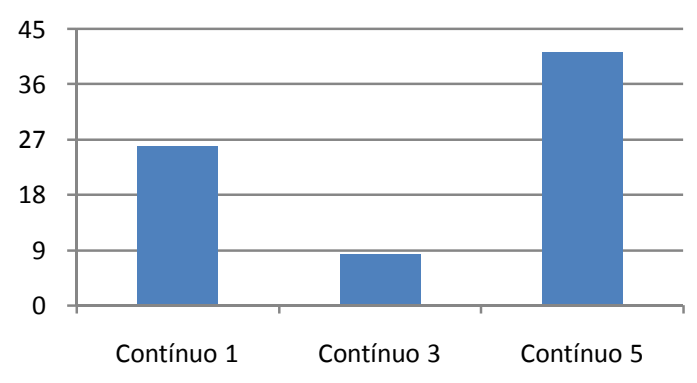

Gráfico 49: Comparação entre os ensaios contínuos com $\mathrm{D}=0,5 \mathrm{dia}^{-1}$ em meio SF 900 II puro.

A concentração residual de glutamina (Gráfico 49c) apresentou uma maior variação entre os ensaios (cv=15\%). A concentração observada foi no Contínuo 5 de 0,42 g/L, no Contínuo e foi 0,46 g/L e a maior foi no Contínuo 3 (0,56 g/L). 
A concentração de amônio formada (Gráfico 48d) também foi próxima no três estados estacionários, com concentrações variadas entre 0,28 e 0,3 . O coeficiente de variação foi de $3 \%$.

Como observado na fase em batelada, os dados relacionados à GPV são os que mais variaram entre os ensaios. $O$ teor de GPV variou entre 0,15 a $0,7 \mu \mathrm{g} / 10^{7} \mathrm{cel}(\mathrm{cv}=68 \%)$ e a produtividade máxima entre 8,3 e $41,2 \mu \mathrm{g} / \mathrm{L} . \mathrm{h}$ (cv=65\%).

O Gráfico 50 mostra a concentração de aminoácidos nos três estados estacionários. Pode-se notar também que existe uma pequena diferença entre os ensaios.

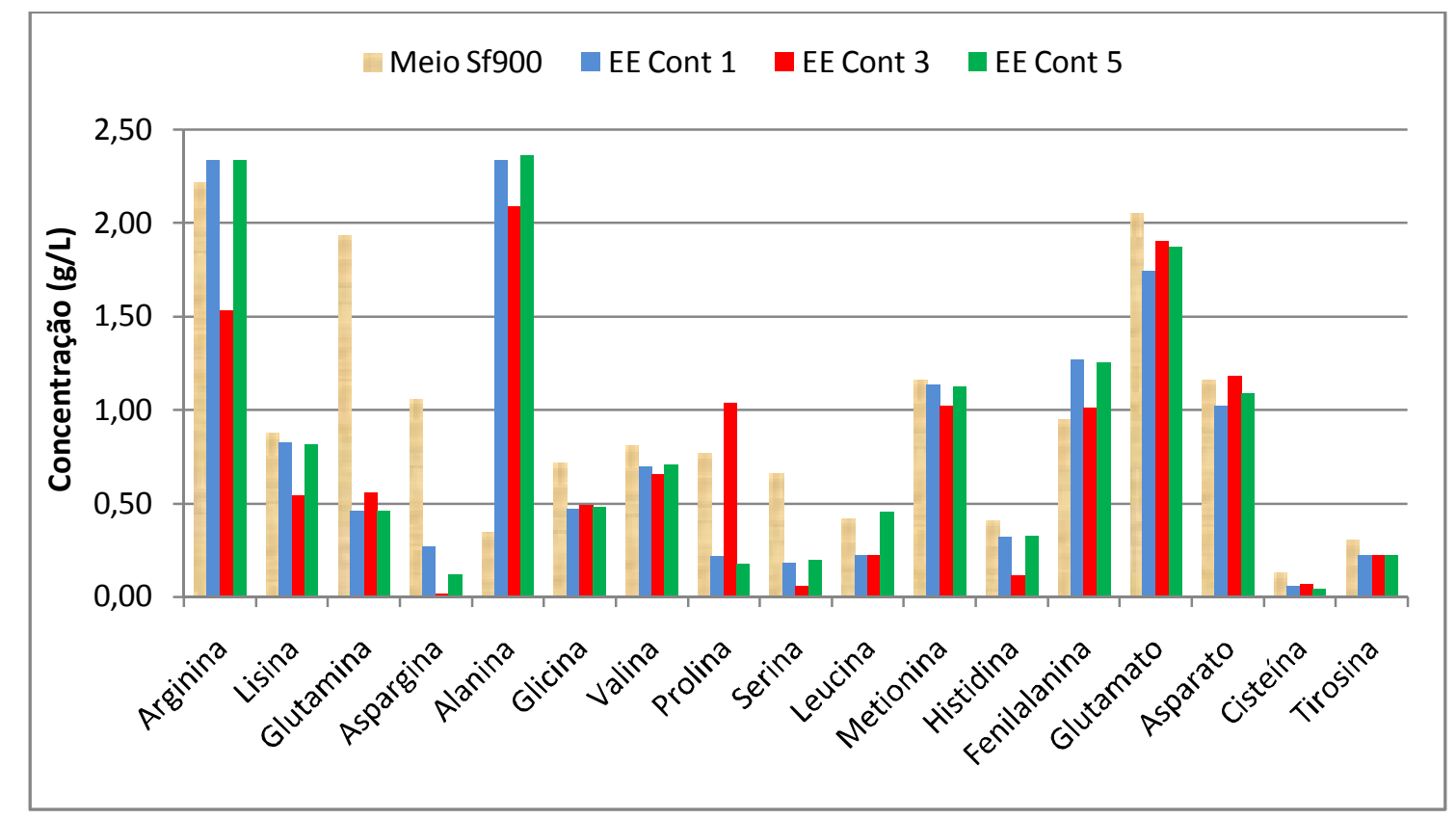

Gráfico 50: Concentração residual de aminoácidos nos estados estacionário alcançados com $\mathrm{D}=0,5$ dia $^{-1}$ em meio SF 900 II no Contínuo 1, 3 e 5.

A tabela 11 mostra os fatores de conversão calculados para cada estado estacionário nos cultivos contínuos.

Como observado na Tabela 11, os coeficientes de variação entre os estados estacionários não foram superiores a $20 \%$. Ou seja, estes resultados sugerem que o metabolismo celular permaneceu constante em todos os ensaios. Indicando uma maior estabilidade das células neste modo de operação. 
Tabela 12: Cálculo de fatores de conversão nos estados estacionários com $D=0,5$ dia $^{-1}$ nos Contínuos

\begin{tabular}{cccccc}
\hline Contínuos & $\begin{array}{c}\mathbf{Y}_{\mathrm{X} / \mathrm{GLC} \text { (célula/g }} \\
\text { glicose }\end{array}$ & $\begin{array}{c}\mathbf{Y}_{\mathrm{x} / \mathrm{GLN}} \text { (célula/g } \\
\text { glutamina) }\end{array}$ & $\begin{array}{c}\mathbf{Y}_{\mathrm{X} / \mathrm{CIS}} \text { (célula/g } \\
\text { de cisteína) }\end{array}$ & $\begin{array}{c}\mathbf{Y}_{\mathrm{NH} / \mathrm{GLN}} \\
\text { (g NH} / \mathrm{g} \\
\text { glutamina) }\end{array}$ & $\begin{array}{c}\mathbf{Y}_{\mathrm{ALA} / \mathrm{GLN}} \\
\text { (g alanina/g } \\
\text { glutamina) }\end{array}$ \\
\hline 1 & $4,79 \mathrm{E}+09$ & $2,37 \mathrm{E}+10$ & $3,29 \mathrm{E}+08$ & 0,227 & 1,85 \\
3 & $6,35 \mathrm{E}+09$ & $2,09 \mathrm{E}+10$ & $4,49 \mathrm{E}+08$ & 0,194 & 1,26 \\
5 & $5,42 \mathrm{E}+09$ & $2,19 \mathrm{E}+10$ & $3,13 \mathrm{E}+08$ & 0,195 & 1,64 \\
CV (\%) & $\mathbf{1 4}$ & $\mathbf{6}$ & $\mathbf{2 0}$ & $\mathbf{9}$ & $\mathbf{1 9}$
\end{tabular}

Com base nestes resultados é possível afirmar que a variabilidade da célula em batelada é superior a do contínuo (com exceção da GPV). Ou seja, mesmo alcançando um coeficiente de variação de $20 \%$, podem-se validar os estados estacionários dos três ensaios contínuos.

Isso leva a crer que as variabilidades geradas pelos inóculos descongelados em tempos distintos geram diferenças nas fases descontínuas que foram eliminadas durante os estados estacionários. Tal fato, se comprovado, acrescenta uma vantagem ao processo contínuo: estabilidade da linhagem.

Com relação à GPV, além da análise de GPV por ELISA possuir um erro experimental de 20\% (AGUIAR, 2010), neste trabalho ainda houve amostras com problemas na extração desta proteína. Ambos os fatos podem explicar um coeficiente de variação tão elevado. 


\section{CONCLUSÕES}

As principais conclusões do trabalho são:

1) Nos experimentos em batelada com as células de inseto, a velocidade específica de crescimento máxima encontrada para as células S2MtGPV foi maior que para as células S2AcGPV, sendo ambas cultivadas sob as mesmas condições de operação.

2) A indução com o sulfato de cobre sobre as células S2MtGPV é prejudicial ao crescimento das células, inviabilizando seu uso em cultivos contínuos. Os resultados indicam que a expressão de GPV por célula continuaria a mesma. Porém, a velocidade específica de crescimento não se manteve constante ao longo do tempo. Uma vez que no processo contínuo a taxa de diluição é imposta e fixa, seria possível ocorrer uma lavagem no reator ao longo de tempo.

3) É possível cultivar células S2AcGPV em processo contínuo e alcançar diferentes estados estacionários, comprovados por coeficientes de variação.

4) Em sistema contínuo operando em diferentes vazões específicas de 0,8 $\mathrm{dia}^{-1}, 0,5 \mathrm{dia}^{-1}$ e de 0,2 dia ${ }^{-1}$ e mesmo meio de cultura, o estado estacionário foi atingido com concentrações celulares próximas. Isto se deve ao fato de que as vazões específicas de alimentação são distantes do $\mu_{\text {máx. }}$

5) Um aumento na concentração de glutamina no meio SF 900 II em experimentos em schott não alterou a concentração celular máxima alcançada tampouco a velocidade específica máxima de crescimento.

6) A adição de $1,7 \mathrm{~g} / \mathrm{L}$ glutamina no meio de alimentação SF 900 II em processo contínuo não resultou em aumento da concentração celular no estado estacionário. Este fato indica de que a glutamina não deva ser o substrato limitante deste processo. 
7) Ensaios em schott com adição de asparagina, prolina, serina e cisteína alcançaram menor velocidade específica máxima de crescimento quando comparada ao ensaio com SF 900 II puro.

8) A adição de prolina, serina e asparagina (separadamente) nos ensaios em schott resultou em uma diminuição da velocidade específica máxima de crescimento. Há indícios de que, isoladamente, estes aminoácidos na concentração adicionada inibiram o crescimento celular.

9) Por sua vez, a cisteína também alcançou uma maior velocidade específica máxima de crescimento em comparação com o ensaio com SF 900 II puro em ensaios em schott. Verifica-se ainda um prolongamento do período da fase estacionária, indicando um possível substrato limitante.

10) A máxima produção específica de GPV nos ensaios em schott foi observada no meio suplementado com serina.

11) Apesar da grande variabilidade dos dados de análise de teor de GPV entre os ensaios contínuos, foi possível alcançar uma alta produtividade nesse tipo de processo. Porém, do ponto de vista da eficiência e produtividade relativa aos processos em batelada seria necessário a realização de mais experimentos comparados.

12) Em processo contínuo, o meio de alimentação suplementado com prolina, serina, asparagina e cisteína não alterou a concentração celular no estado estacionário. Este fato pode ter ocorrido devido à inibição do crescimento celular por excesso destes aminoácidos (com exceção da cisteína) ou por um aumento na formação de metabólitos tóxicos para as células.

13) Os resultados do ensaio contínuo mostraram que a adição de cisteína no meio SF 900 II aumentou o consumo global de aminoácidos gerando um aumento de $12 \%$ na concentração celular. É possível que a cisteína seja um dos substratos limitantes do processo.

14) Para uma mesma taxa de diluição, foi possível validar o estado estacionário, uma vez que, variáveis como concentração celular, 
concentrações de glicose e de glutamina residual, concentração de aminoácidos e fatores de conversão permaneceram constantes. Ou seja, a célula se comportou de maneira semelhante nos três ensaios e em diferentes tempos de cultivo.

De maneira geral, pode-se concluir com os resultados obtidos ao longo deste trabalho que o cultivo de células $\mathrm{S} 2$ em processo contínuo constitui um método viável para a compreensão do metabolismo desta célula. Verifica-se que a mesma não apresentou grande variabilidade em ensaios diferentes quando imposta a uma mesma vazão específica de alimentação. Espera-se que as conclusões aqui alcançadas contribuam para a otimização dos processos em batelada ou batelada alimentada, visto que são os mais utilizados na indústria. 


\section{SUGESTÃO PARA TRABALHOS FUTUROS}

Para dar continuidade ao trabalho desenvolvido, sugere-se:

1) Para um melhor entendimento do metabolismo das células S2AcGPV, a realização de mais ensaios contínuos com adição dos mesmos aminoácidos testados e com a histidina combinados entre si e analisados separadamente.

2) Uma melhor análise de metabólitos tóxicos para esta célula, principalmente, o amônio.

3) Visando alcançar maiores concentrações de GPV, sugere-se a adição de serina e cisteína em diferentes concentrações no meio SF 900 II.

4) Verificação do efeito de diferentes concentrações de glicose e de glutamina nestas células em meio definido (em processo contínuo).

5) Uma ampliação na faixa de concentração do estudo voltado para otimização de meios de cultura para esta célula em processo contínuo.

6) Realização de ensaio contínuo em cascata com células S2MtGPV. 


\section{REFERÊNCIAS BIBLIOGRÁFICAS}

Aguiar, M.A. 2010. Estudo Cinético de Células de Drosoplhila melanogaster para a Produção da Glicoproteína do Vírus da Raiva em Biorreator. Vol. Dissertação de Mestrado. Universidade de São Paulo (USP), São Paulo.

Amable, P., and Butler, M. 2008. Cell metabolism and its control in culture. In Moraes, A.M., Augusto, E., Castilho, L.R., and Butler, M. Animal cell technology. Taylor \& Francis, London. 75 - 110.

Ashburner, M. 1989. Drosophila. A laboratory handbook, New York. i-xliii, 1-1331 pp.

Astray, R., Augusto, E., Yokomizo, A., and Pereira, C. 2008. Analytical approach for the extraction of recombinant membrane viral glycoprotein from stably transfected Drosophila melanogaster cells. Biotechnol Journal. 3:98-103.

Augusto, E.F.P., Moraes, A.M., Piccoli, R.A.M., Barral, M.F., Suazo, C.A.T., Tonso, A., and Pereira, C.A. 2010. Nomenclature and guideline to express the amount of a membrane protein synthesized in animal cells in view of bioprocess optimization and production monitoring. Biologicals. 38:105-112.

Augusto, E.F.P., and Oliveira, M.S. 2001. Processos com células animais. In Lima, U.A., Aquarone, E., Borzani, W., and Schimidell, W. Biotecnologia industrial. . Vol. 2. Edgard Blücher, São Paulo.

Bahloul, C., Jacob, Y., Tordo, N., and Perrin, P. 1998. DNA-based immunization for exploring the enlargement of immunological cross-reactivity against the lyssaviruses. Vaccine. 16:417-425.

Batista, F.R.X., Moraes, A.M., Buntemeyer, H., and Noll, T. 2009. Influence of culture conditions on recombinant Drosophila melanogaster S2 cells producing rabies virus glycoprotein cultivated in serum-free medium. Biologicals. 37:108-118.

Batista, F.R.X., Pereira, C.A., Mendonca, R.Z., and Moraes, A.M. 2008. Formulation of a protein-free medium based on IPL-41 for the sustained growth of Drosophila melanogaster S2 cells. Cytotechnology. 57:11-22.

Bhatia, R., Jesionowski, G., Ferrance, J., and Ataai, M.M. 1997. Insect cell physiology. Cytotechnology. 24:1-9.

Bovo, R., Galesi, A.L.L., Jorge, S.A.C., Piccoli, R.A.M., Moraes, A.M., Pereira, C.A., and Augusto, E.F.P. 2008. Kinetic response of a Drosophila melanogaster cell line to different medium formulations and culture conditions. Cytotechnology. 57:23-35.

Butler, M. 2004. Animal Cell Culture \&Technology: The basics. BIOS, London.

Butler, M. 2005. Animal cell cultures: recent achievements and perspectives in the production of biopharmaceuticals. Applied Microbiology and Biotechnology. 68:283-291.

CCAUFES - Centro de Ciência Agrária da Universidade Federal do Espírito Santo. Disponível em: <http://www.cca.ufes.br>. Acesso em: 28 de maio de 2007.

Cherbas, L., Moss, R., and Cherbas, P. 1994. Transformation techniques for Drosophila cell lines. Methods Cell Biol. 44:161-179. 
Chiou, T.W., Hsieh, Y.C., and Ho, C.S. 2000. High density culture of insect cells using rational medium design and feeding strategy. Bioprocess and Biosystems Engineering. 22:483-491.

Costa, J.P.C.L. 2008. Análise da produção do antitumoral retamicina em cultivos contínuos de Streptomyces olindensis ICB20 utilizando planejamento fatorial.Engenharia Química. Vol. Tese de Doutorado. Uneiversidade de São Paulo (USP), São Paulo.

Cruz, H.J., Moreira, J.L., and Carrondo, M.J.T. 1999. Metabolic shifts by nutrient manipulation in continuous cultures of BHK cells. Biotechnology and Bioengineering. 66:104-113.

Deml, L., Wolf, H., and Wagner, R. 1999. High level expression of hepatitis B virus surface antigen in stably transfected Drosophila Schneider-2 cells. Journal of Virological Methods. 79:191-203.

Deutschmann, S.M., and Jager, V. 1994. Optoptimization of the growth-conditions of sf21 insect cells for high-density perfusion culture in stirred-tank bioreactors. Enzyme and Microbial Technology. 16:506-512.

Doverskog, M., Han, L., and Häggström, L. 1998. Cystine/cysteine metabolism in cultured Sf9 cells: influence of cell physiology on biosynthesis, amino acid uptake and growth. Cytotechnology. 26:91-102.

Doverskog, M., Ljunggren, J., Öhman, L., and Häggström, L. 1997. Physiology of cultured animal cells. Journal of Biotechnology. 59:103-115.

Drews, M., Doverskog, M., Öhman, L., Chapman, B., Jacobsson, U., Kuchel, P., and Häggström, L. 2000. Pathways of glutamine metabolism in Spodoptera frugiperda (Sf9) insect cells: evidence for the presence of the nitrogen assimilation system, and a metabolic switch by $1 \mathrm{H} / 15 \mathrm{~N}$ NMR. J Biotechnol. 78:23-37.

Drews, M., Paalme, T., and Vilu, R. 1995. The growth and nutrient utilization of the insect cell line Spodoptera frugiperda Sf9 in batch and continuous culture. Journal of Biotechnology. 40:187-198.

Eagle, H. 1955. Nutrition needs of mammalian cells in tissue culture. Science. 122:501-504.

Enders, J.F., Weller, T.H., and Robbins, F.C. 1949. Cultivation of the lansing strain of poliomyelitis virus in cultures of various human embryonic tissues. Science. 109:85-87.

Facciotti, M.C.R. Fermentação Contínua. In. Shimidell Neto, W. et al. (Coord.). Biotecnologia Industrial. São Paulo: Edgard Blucher, 2001. v 2, pág. 223246.

Feng, Q., Mi, L., Li, L., Liu, R., Xie, L., Tang, H., and Chen, Z.N. 2006. Application of "oxygen uptake rate-amino acids" associated mode in controlled-fed perfusion culture. Journal of Biotechnology. 122:422-430.

Ferrance, J.P., Goel, A., and Ataai, M.M. 1993. Utilization of glucose and aminoacids in insect-cell cultures - quantifying the metabolic flows within the primary pathways and medium development. Biotechnology and Bioengineering. 42:697-707. 
Finkelstein, J. 1998. Methionine-sparing effect of cystine in human subjects. $A m J$ Clin Nutr. 68:224-225.

Freedman, R.B. 1984. Native disulphide bond formation in protein biosynthesis: evidence for the role of protein disulphide isomerase. Trends in Biochemical Sciences. 9:438-441.

Freshney, R.I. 2005. Culture of animal cells: A manual of basic technique. Springer Berlin / Heidelberg.

Galesi, A.L.L., Aguiar, M.A., Astray, R.M., Augusto, E.F.P., and Moraes, A.M. 2008. Growth of recombinant Drosophila melanogaster Schneider 2 cells producing rabies virus glycoprotein in bioreactor employing serum-free medium. Cytotechnology. 57:73-81.

Galesi, A.L.L., Batista, F.R.X., Mendonca, R.Z., Pereira, C.A., and Moraes, A.M. 2007. Design of culture media for Drosophila melanogaster $S 2$ cells producing recombinant $\mathrm{G}$ glycoprotein from rabies virus. Cell Technology for Cell Products:403-413.

Grace, T.D.C., and Brozostowski, H.W. 1966. Analysis of the amino acids and sugars in an insect cell culture medium during cell growth. Journal of Insect Physiology. 12:625-633.

Griffiths, J.B. 1992. Animal cell culture processes - batch or continuous. . Journal of Biotechnology. 22:21-30.

Guy, E. 1997. Drosophila cells in culture. Academy press, San Diego.

Häggström, L. 1991. Energetics of glutaminolysis - a theoretical evaluation. Production of Biologicals from Animal Cells in Culture:79-81.

Harrison, R.G. 1907. Observations on the living developing nerve fiber. Proceedings of the Society for Experimental Biology and Medicine. 4:140-143.

Hayter, P.M., Curling, E.M.A., Baines, A.J., Jenkins, N., Salmon, I., Strange, P.G., and Bull, A.T. 1991. Chinese-hamster ovary cell-growth and interferonproduction kinetics in stirred batch culture. Applied Microbiology and Biotechnology. 34:559-564.

Hayter, P.M., Curling, E.M.A., Gould, M.L., Baines, A.J., Jenkins, N., Salmon, I., Strange, P.G., and Bull, A.T. 1993. The effect of the dilution rate on cho cell physiology and recombinant interferon-gamma production in glucose-limited chemostat culture. Biotechnology and Bioengineering. 42:1077-1085.

Hiller, G.W., Clark, D.S., and Blancht, H.W. 1993. Transient responses os Hybridoma cells in continuous culture to step changes in amino acid and vitamin concentrations. Biotechnology and Bioengineering. 44:303-321.

Ikonomou, L., Schneider, Y.J., and Agathos, S.N. 2003. Insect cell culture for industrial production of recombinant proteins. Applied Microbiology and Biotechnology. 62:1-20.

Jardin, B.A., Montes, J., Lanthler, S., Tran, R., and Elias, C. 2007. High cell density fed batch and perfusion processes for stable non-viral expression of secreted alkaline phosphatase (SEAP) using insect cells: Comparison to a batch Sf-9BEV system. Biotechnology and Bioengineering. 97:332-345. 
Jentoft, N. 1990. Why are proteins o-glycosylated. Trends in Biochemical Sciences. 15:291-294.

Kieny, M.P., Lathe, R., Drillien, R., Spehner, D., Skory, S., Schmitt, D., Wiktor, T., Koprowski, H., and Lecocq, J.P. 1984. Expression of rabies virus glycoprotein from a recombinant vaccinia virus. Nature. 312:163-166.

Klepfer, S.R., Debouck, C., Uffelman, J., Jacobs, P., Bollen, A., and Jones, E.V. 1993. Characterization of rabies glycoprotein expressed in yeast. Archives of Virology. 128:269-286.

Kretzmer, G. 2002. Industrial processes with animal cells. Applied Microbiology and Biotechnology. 59:135-142.

Lathe, R., Kieny, M., Schmitt, D., Curtis, P., and Lecocq, J. 1984. M13 bacteriophage vectors for the expression of foreign proteins in Escherichia coli: the rabies glycoprotein. J Mol Appl Genet. 2:331-342.

Lee, J.C., Kim, D.Y., Oh, D.J., and Chang, H.N. 2008. Long-term operation of depth filter perfusion systems (DFPS) for monoclonal antibody production using recombinant $\mathrm{CHO}$ cells: Effect of temperature, $\mathrm{pH}$, and dissolved oxygen. Biotechnology and Bioprocess Engineering. 13:401-409.

Lemos, M.A.N. 2009. Construção e transfecção de vetores plasmidiais contendo o gene da glicoproteína do vírus da raiva (GPV) em células de Drosophila melanogaster. Vol. Dissertação de Mestrado. Universedade de São Paulo (USP), São Paulo.

Lemos, M.A.N., dos Santos, A.S., Astray, R.M., Pereira, C.A., and Jorge, S.A.C. 2009. Rabies virus glycoprotein expression in Drosophila S2 cells. I: Design of expression/selection vectors, subpopulations selection and influence of sodium butyrate and culture medium on protein expression. Journal of Biotechnology. 143:103-110.

Levine, S., and Berenson, K. 2005. Estatística - Teoria e Aplicações, Rio de Janeiro. 312 - 315 pp.

Li, B., Tsing, S., Kosaka, A.H., Nguyen, B., Osen, E.G., Bach, C., Chan, H., and Barnett, J. 1996. Expression of human dopamine beta-hydroxylase in Drosophila Schneider 2 cells. Biochemical Journal. 313:57-64.

Maillard, A.P., and Gaudin, Y. 2002. Rabies virus glycoprotein can fold in two alternative, antigenically distinct conformations depending on membraneanchor type. Journal of General Virology. 83:1465-1476.

Mendonca, R.Z., Greco, K.N., Moraes, R.H.P., Astray, R.M., and Barral, M. 2009. Study of kinetic parameters for the production of recombinant rabies virus glycoprotein. Cytotechnology. 60:143-151.

Mendonca, R.Z., Greco, K.N., Sousa, A.P.B., Moraes, R.H.P., Astray, R.M., and Pereira, C.A. 2008. Enhancing effect of a protein from Lonomia obliqua hemolymph on recombinant protein production. Cytotechnology. 57:83-91.

Mendonca, R.Z., Palomares, L.A., and Ramirez, O.T. 1999. An insight into insect cell metabolism through selective nutrient manipulation. Journal of Biotechnology. 72:61-75. 
Meuwly, F., Papp, F., Ruffieux, P.A., Bernard, A.R., Kadouri, A., and von Stockar, U. 2006. Use of glucose consumption rate (GCR) as a tool to monitor and control animal cell production processes in packed-bed bioreactors. Journal of Biotechnology. 122:122-129.

Mochizuki, H., Schwartz, J.P., Tanaka, K., Brady, R.O., and Reiser, J. 1998. Hightiter human immunodeficiency virus type 1-based vector systems for gene delivery into nondividing cells. Journal of Virology. 72:8873-8883.

Morimoto, K., Kawai, A., and Mifune, K. 1992. Comparison of rabies virus-g proteins produced by cdna-transfected animal-cells that display either inducible or constitutive expression of the gene. Journal of General Virology. 73:335-345.

Nyberg, G.B., Balcarcel, R.R., Follstad, B.D., Stephanopoulos, G., and Wang, D.I.C. 1999. Metabolism of peptide amino acids by Chinese hamster ovary cells grown in a complex medium. Biotechnology and Bioengineering. 62:324-335.

Öhman, L., Alarcon, M., Ljunggren, J., Ramqvist, A.-K., and Häggström, L. 1996. Glutamine is not an essential amino acid for Sf-9 insect cells. Biotechnology Letters. 18:765-770.

Omasa, T., Furuichi, K., lemura, T., Katakura, Y., Kishimoto, M., and Suga, K.-i. 2010. Enhanced antibody production following intermediate addition based on flux analysis in mammalian cell continuous culture. Bioprocess and Biosystems Engineering. 33:117-125.

Pamboukian, M.M. 2007. Estudo da atividade respiratória de linhagens selvagens e transfectadas de células de insetos através de cultivos em biorreatores.Engenharia Química. Vol. Dissertação de Mestrado. Universidade de São Paulo (USP), São Paulo.

Pamboukian, M.M., Jorge, S.A., Santos, M.G., Yokomizo, A.Y., Pereira, C.A., and Tonso, A. 2008. Insect cells respiratory activity in bioreactor. Cytotechnology. 57:37-44.

Pamboukian, M. M.; Pereira, C. A.; Augusto E. F. P.; Tonso, A. 2009. Development of a MATLAB application for processing kinetic data of animal cells experiments. In: Anais da XI Reunião Científica Anual do Instituto Butantan, Instituto Butantan: São Paulo.

Pauster,

http://www.pasteur.saude.sp.gov.br/informacoes/anais/seminario_internaciona I/resumo_2_1.htm.19/10/2009

Pijlman, G.P., de Vrij, J., van den End, F.J., Vlak, J.M., and Martens, D.E. 2004. Evaluation of baculovirus expression vectors with enhanced stability in continuous cascaded insect-cell bioreactors. Biotechnology and Bioengineering. 87:743-753.

Pijlman, G.P., de Vrij, J., van den End, F.J., Vlak, J.M., and Martens, D.E. 2004. Evaluation of baculovirus expression vectors with enhanced stability in continuous cascaded insect-cell bioreactors. Biotechnology and Bioengineering. 87:743-753.

Pinto, R.C.V., Medronho, R.A., and Castilho, L.R. 2008. Separation of CHO cells using hydrocyclones. Cytotechnology. 56:57-67. 
Prehaud, C., Lay, S., Dietzschold, B., and Lafon, M. 2003. Glycoprotein of nonpathogenic rabies viruses is a key determinant of human cell apoptosis. Journal of Virology. 77:10537-10547.

Radford, K.M.; Reid, S.; Greenfield, P.F. 1997. Substrate limitation in the baculovirus expression vector system. Biotechnology and Bioengineering, v.56, p.32ï 44.

Rossi, N. 2008. Efeito da temperatura na otimização da produção de glicoproteína do vírus da raiva em cultivos em suspensão de células recombinantes de Drosophila melanogaster S2.Centro de Ciências Exatas e Tecnológicas. Vol. Dissertação de Mestrado. Universidade de São Paulo, São Carlos.

Sakamoto, S., Ide, T., Tokiyoshi, S., Nakao, J., Hamada, F., Yamamoto, M., Grosby, J.A., Ni, Y.J., and Kawai, A. 1999. Studies on the structures and antigenic properties of rabies virus glycoprotein analogues produced in yeast cells. Vaccine. 17:205-218.

Santos, M.G., Jorge, S.A.C., Brillet, K., and Pereira, C.A. 2007. Improving heterologous protein expression in transfected Drosophila $\mathrm{S} 2$ cells as assessed by EGFP expression. Cytotechnology. 54:15-24.

Schmidell, W. 2001. Agitação e aeração em biorreatores. In Biotecnologia industrial. Vol. 2. Blücher, E., editor, SÃO PAULO. 277-331.

Schneider, I. 1972. Cell lines derived from late embryonic stages of Drosophila melanogaster. Journal of Embryology and Experimental Morphology. 27:353$\&$.

Shin, H., and Cha, H. 2002. Facile and statistical optimization of transfection conditions for secretion of foreign proteins from insect Drosophila S2 cells using green fluorescent protein reporter. Biotechnol Prog. 18:1187-1194.

Shin, H., Lim, H., and Cha, H. 2003. Quantitative monitoring for secreted production of human interleukin-2 in stable insect Drosophila $\mathrm{S} 2$ cells using a green fluorescent protein fusion partner. Biotechnol Prog. 19:152-157.

Sondergaard, L. 1996. Drosophila cells can be grown to high cell densities in a bioreactor. Biotechnology Techniques. 10:161-166.

Swiech, K. 2007. Caracterização cinética e fisiológica de células de Drosophila melanogaster S2 para produção de Glicoproteína do Vírus da Vaiva (GPV) recombinante.Engenharia Química. Vol. Tese de Doutorado. Universidade Federal de São Carlos, São Carlos.

Swiech, K., da Silva, C.S., Arantes, M.K., dos Santos, A.S., Astray, R.M., Pereira, C.A., and Suazo, C.A.T. 2008. Characterization of growth and metabolism of Drosophil melanogaster cells transfected with the rabies-virus glycoprotein gene. Biotechnology and Applied Biochemistry. 49:41-49.

Swiech, K., Rossi, N., Silva, B.G., Jorge, S.A.C., Astray, R.M., and Suazo, C.A. 2008. Bioreactor culture of recombinant Drosophila melanogaster $\mathrm{S} 2$ cells: characterization of metabolic features related to cell growth and production of the rabies virus glycoprotein. Cytotechnology. 57:61-66.

Tokashiki, M., and Yokoyama, S. 1997. Bioreactors designed for animal cells. In Mammalian Cell Biotechnology in Protein Production. Gruyter, W.d., editor, Berlin. 
Tonso, A. 2000. Monitoramento e Operação de cultivos de células animais em sistema de perfusão. Engenharia Química. Vol. Tese de Doutorado. Universidade de São Paulo (USP), São Paulo.

Triola, M.F. 2005. Introdução à estatística., Rio de Janeiro.

Vacinas. www.vacinas.org.br. 19 de outubro

Vaugh, J. 1999. Insect cell culture, protein expression. 1444-1457 pp.

Ventini, D.C., Astray, R.M., Lemos, M.A.N., Jorge, S.A.C., Riquelme, C.C., Suazo, C.A.T., Tonso, A., and Pereira, C.A. 2010. Recombinant rabies virus glycoprotein synthesis in bioreactor by transfected Drosophila melanogaster S2 cells carrying a constitutive or an inducible promoter. Journal of Biotechnology. 146:169-172.

Wang, M.D., Yang, M., Huzel, N., and Butler, M. 2002. Erythropoietin production from $\mathrm{CHO}$ cells grown by continuous culture in a fluidized-bed bioreactor. Biotechnology and Bioengineering. 77:194-203.

Wang, M.Y., and Bentley, W.E. 1994. Continuous insect-cell (sf-9) culture with aeration through sparging. Applied Microbiology and Biotechnology. 41:317323.

Wang, M.Y., Kwong, S., and Bentley, W.E. 1993. Effects of oxygen glucose glutamine feeding on insect-cell baculovirus protein expression - a study on epoxide hydrolase production. Biotechnology Progress. 9:355-361.

Yokomizo, A., Jorge, S., Astray, R., Fernandes, I., Ribeiro, O., Horton, D., Tonso, A., Tordo, N., and Pereira, C. 2007. Rabies virus glycoprotein expression in Drosophila S2 cells. I. Functional recombinant protein in stable co-transfected cell line. Biotechnol J. 2:102-109. 